MRS/IS Facility Co-Located with a Repository:

Preconceptual Design and

Life Cycle Cost Estimates

R. I. Smith

J. F. Nesbitt

November 1982

Prepared for the U.S. Department of Energy under Contract DE-AC06-76RLO 1830

Pacific Northwest Laboratory

Operated for the U.S. Department of Energy

by Battelle Memorial Institute 


\title{
DISCLAIMER
}

This report was prepared as an account of work sponsored by an agency of the United States Government. Neither the United States Government nor any agency thereof, nor any of their employees, makes any warranty, express or implied, or assumes any legal liability or responsibility for the accuracy, completeness, or usefulness of any information, apparatus, product, or process disclosed, or represents that its use would not infringe privately owned rights. Reference herein to any specific commercial product, process, or service by trade name, trademark, manufacturer, or otherwise, does not necessarily constitute or imply its endorsement, recommendation, or favoring by the United States Government or any agency thereof. The views and opinions of authors expressed herein do not necessarily state or reflect those of the United States Government or any agency thereof.

\author{
PACIFIC NORTHWEST LABORATORY \\ operated by \\ BATTELLE \\ for the \\ UNITED STATES DEPARTMENT OF ENERGY \\ under Contract DE-AC06-76RLO 1830
}

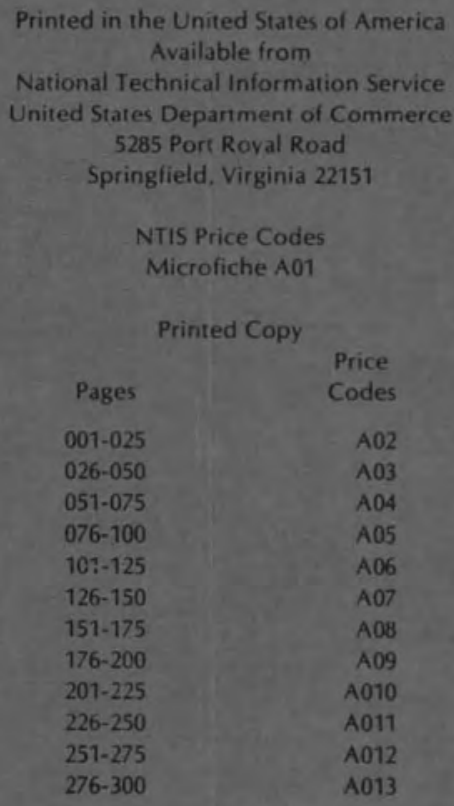




\section{MRS/IS FACILITY CO-LOCATED WITH A REPOSITORY: PRECONCEPTUAL DESIGN AND LIFE CYCLE COST ESTIMATES}

R. I. Smith

J. F. Nesbitt

November 1982

Prepared for the U.S. Department of Energy under Contract DE-AC06-76RLO 1830

Pacific Northwest Laboratory

Richland, Washington 99352 


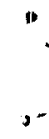

.

$-$

"'

-

" 


\section{ACKNOWLEDGMENTS}

This report represents the cumulative result of the effort of a number of individuals.

The bulk of Section 4, dealing with the conceptual facility design and construction costs, was developed from information provided by a team from Westinghouse-Hanford Co., consisting principally of J. C. Sonnichsen, K. D. Hayden, J. A. Partridge, and D. A. Cantley, led by M. C. J. Carlson. The Westinghouse team obtained considerable assistance in detailing the facility construction costs from Kaiser Engineers - Oakland.

Appendix A was developed by E. T. Merrill of PNL. Appendix $B$ was developed by PNL staff members E. T. Merrill and B. M. Cole, led by J. F. Fletcher. Appendix $C$ was developed by P. M. Daling of PNL. Appendix $D$ is based on material developed by K. D. Hayden of Westinghouse-Hanford $\mathrm{Co}$.

Responsibility for assembling and integrating the information, performing the necessary analyses, and drafting the rest of the report rests with the Project Manager, R. I. Smith of PNL, with the very considerable assistance of J. F. Nesbitt of PNL.

H. K. Mills of PNL Word Processing did an outstanding job in transforming the rough draft material into the final copy, and final editing was accomplished by D. R. Payson of PNL's Editing Staff. 


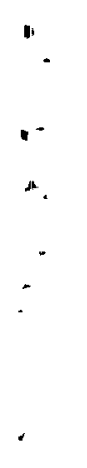

.

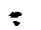
" 


\section{EXECUTIVE SUMMARY}

Changes in recent years in federal policies regarding reprocessing and/or disposal of spent nuclear reactor fuel have produced delays in the development of fuel reprocessing $\mathrm{plants}$ and deep geologic disposal facilities. As a result, many nuclear power plants are faced with the possibility of shutdown due to lack of spent fuel storage capacity. In recognition of this problem, legislative initiatives are underway in Congress to provide appropriate storage and disposal facilities.

The Department of Energy (DOE), through its Office of Nuclear Fuel Cycle, has established a program to examine the various alternatives for storage of spent nuclear fuel, solidified high-level wastes (HLW), and transuranic (TRU) wastes until an appropriate deep geologic repository is available for disposal of these wastes. One of these alternatives, a monitored retrievable storage/interim storage (MRS/IS) facility built on the site of a future repository, is the subject of this stuay.

The MRS/IS facility evaluated in this study is composed of a Waste Handling Facility where the incoming waste shipments are received and the individual fuel assemblies/HLW canisters/TRU containers are examined and decontaminated and/or repackaged as appropriate before transfer to the storage areas. The facility is also composed of storage areas where the spent fuel assemblies and HLW canisters are stored in either large metal storage casks standing on support pads or in subsurface drywells with the surrounding soil providing shielding. In the storage areas, remote-handled TRU wastes (RHTRU) are stored in concrete casks standing on support pads, and contact-handled TRU wastes (CHTRU) are stored in a surface warehouse. Transfer of the stored wastes from the storage areas to the repository is accomplished after the repository is opened.

The objectives of this study are: 1) to develop a preconceptual design for an MRS/IS facility that would become the principal surface facility for a deep geologic repository when the repository is opened, 2) to examine various issues such as transportation of wastes, licensing of the facility, and environmental concerns associated with operation of such a facility, and 
3) to estimate the life cycle costs of the facility when operated in response to a set of scenarios which define the quantities and types of waste requiring storage in specific time periods, which generally span the years from 1990 until 2016.

The life cycle costs estimated in this study include: the capital expenditures for structures, casks and/or drywells, storage areas and pads, and transfer equipment; the cost of staff labor, supplies, and services; and the incremental cost of transporting the waste materials from the site of origin to the MRS/IS facility (and in the case of spent fuel, returning the spent fuel to the reprocessing $\mathrm{plant}$ ).

Three scenarios are examined to develop estimates of life cycle costs of the MRS/IS facility. In the first scenario, HLW canisters are stored, starting in 1990, until the co-located repository is opened in the year 1998. Additional reprocessing plants and repositories are placed in service at various intervals. In the second scenario, spent fuel is stored, starting in 1990 , because the reprocessing plants are delayed in starting operations by 10 years, but no HLW is stored because the repositories open on schedule. In the third scenario, HLW is stored, starting in 1990, because the repositories are delayed 10 years, but the reprocessing plants open on schedule.

The undiscounted life cycle costs for the MRS/IS facility estimated in this study range from $\$ 0.5$ to $\$ 2.5$ billion, depending upon the scenarios. Expenditures for metal storage casks are estimated to range from $\$ 0.30$ to $\$ 1.77$ billion. Cost reductions resulting from the use of drywells instead of metal casks could range from $\$ 0.21$ to $\$ 1.25$ billion. Other cost reductions resulting from consolidation of spent fuel assemblies into closely packed arrays and from the use of large storage casks for offsite shipment of spent fuel and HLW could be more than $\$ 1.6$ billion.

The principal conclusions derived from this study are the following:

- Co-locating the MRS/IS facility with a repository will reduce overall waste management system costs by eliminating the duplication of facilities that would occur if the storage and repository facilities 
were located separately. Since the MRS/IS facility becomes the surface facility for the repository, the useful life of the structure is extended significantly, thus allowing a longer amortization period and a smaller annual amortization charge.

- The stored waste materials would be transferred directly from storage to the repository without leaving the site, thereby minimizing the potential for transportation accidents and the possible exposure of the public resulting from such accidents.

- Because the life cycle cost of an MRS/IS facility is likely to be in the $\$ 0.7$ to $\$ 2.5$ billion range, all avenues available for reducing costs should be explored. The use of drywells instead of metal casks, consolidation of spent fuel assemblies, and the use of the large storage casks for shipment of wastes all show promise for cost reductions. Water pool storage, an alternative not examined in this study, should also be carefully evaluated for comparison with the dry storage alternatives, to select the most cost-effective approach. 


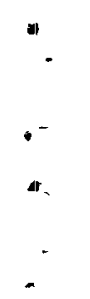




\section{CONTENTS}

ACKNOWLEDGMENTS $\quad \cdot \quad \cdot \quad \cdot \quad \cdot \quad \cdot \quad \cdot \quad \cdot \quad \cdot \quad \cdot \quad \cdot \quad \cdot$

EXECUTIVE SUMMARY

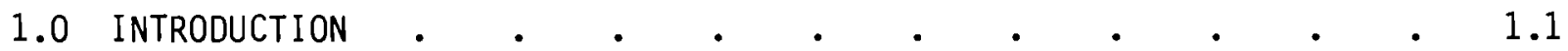

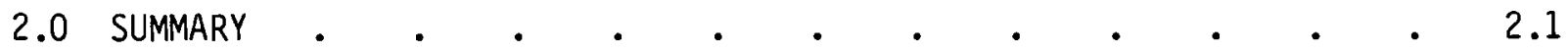

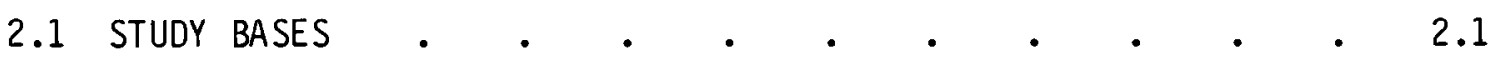

2.2 CONCEPTUAL FACILITY CHARACTERISTICS $\quad$ • $\quad$ • $\quad$ • $\quad$ • 2.3

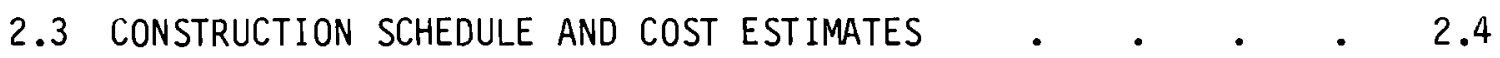

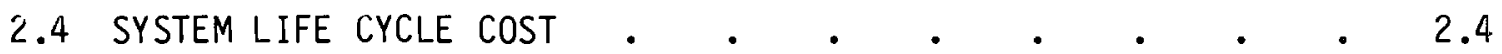

2.5 SENSITIVITY OF COSTS TO CONCEPTS AND ASSUMPTIONS $\quad \cdot \quad \cdot \quad \cdot \quad \cdot 7$

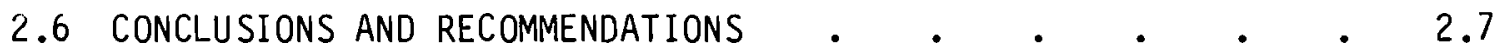

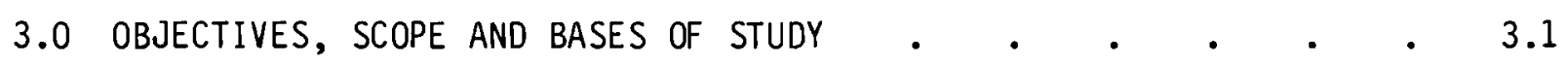

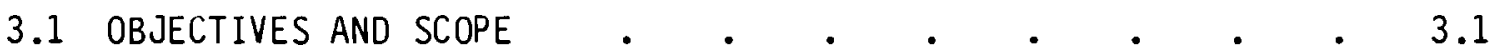

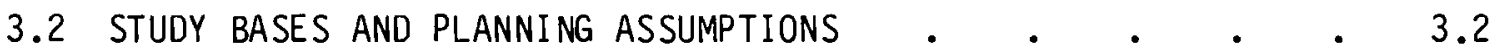

3.2.1 Regulatory Considerations . • • • • • • 3.2

3.2.2 Functional Capabilities . . . . . . . 3.2

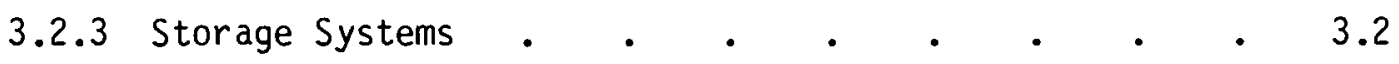

3.2.4 Economic Bases . . . . . . . . . . 3.3

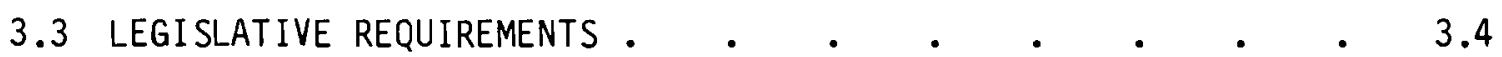

3.3.1 Interim (Emergency) Storage of Spent Fue1 . . $\quad$ • 3.4

3.3.2 Monitored Retrievable Storage . . . . . 3.5

3.3.3 Storage of Transuranic Wastes . . . . . 3.5

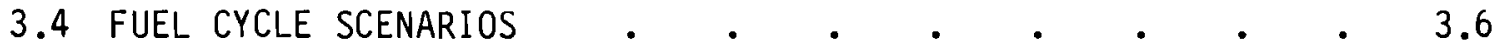

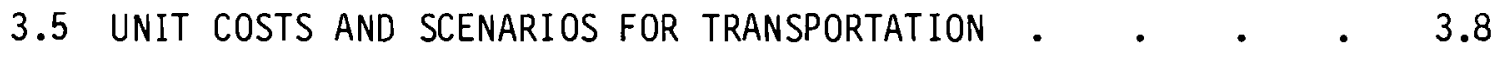

3.5.1 Unit Transportation Costs . $\quad$. $\quad$. $\quad . \quad$. 3.9 
3.5.2 Transportation Scenarios . $\quad$. $\quad$. $\quad$. 3.9

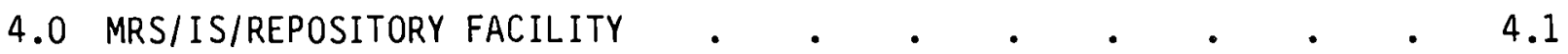

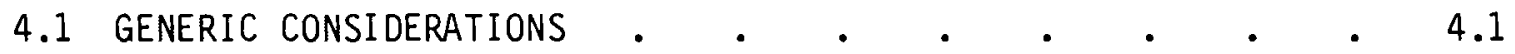

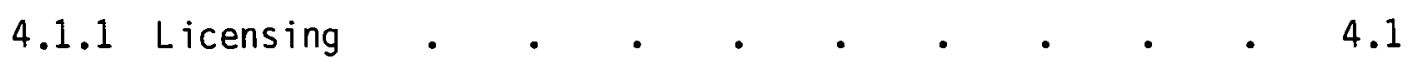

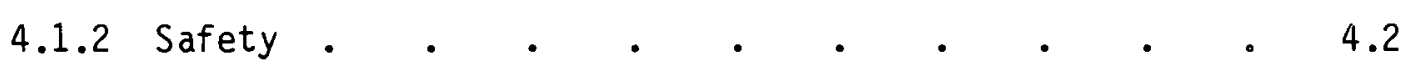

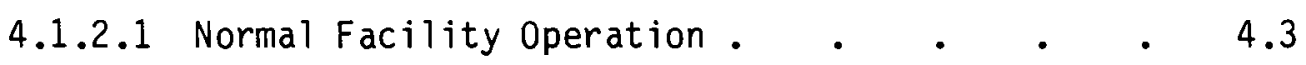

4.1.2.2 Abnormal Operating Conditions . . . . 4.4

4.1.2.3 Improbable Events . . . . . . . . 4.4

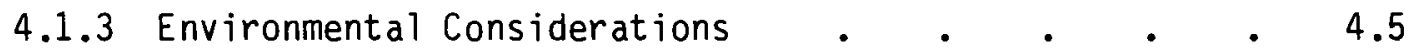

4.1.3.1 Environmental Impacts During Construction . 4.6

4.1.3.2 Environmental Impacts During Operation . . 4.6

4.1.3.3 Environmental Impacts During Decommissioning . $\quad 4.7$

4.1.4 General Standards and Criteria . $\quad . \quad$. $\quad . \quad$. 4.7

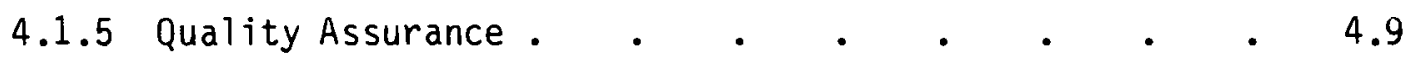

4.1.5.1 Development of QA Program • $\quad$ • $\quad$ • $\quad$ • $\quad 4.9$

4.1.5.2 QA Classifications . . . . . . 4.10

4.1.6 Functional Criteria and System Requirements . 4.11

4.1.6.1 Functional Criteria . $\quad . \quad$. $\quad . \quad$. 4.11

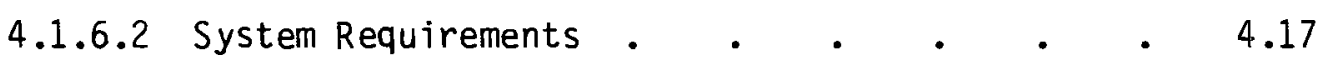

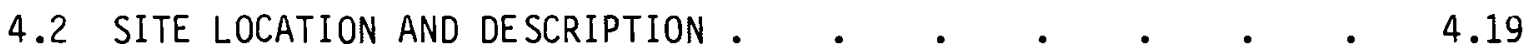

4.2.1 Site Location and Arrangement $\quad$ - $\quad . \quad$. $\quad$. 4.19

4.2.2 Site Parameters . . . . . . . . . $\quad$. 4.23

4.2 .2 .1 Climatology $\quad . \quad$. $\quad . \quad$. $\quad . \quad$. 4.23

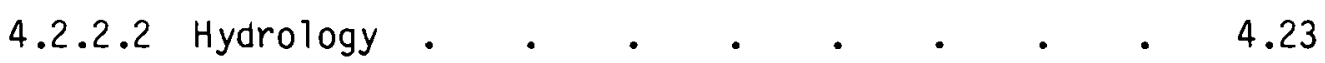

4.2 .2 .3 Ecology $. \quad . \quad . \quad . \quad . \quad . \quad . \quad .4 .24$ 
4.2.2.4 Environment $\quad . \quad$. $\quad . \quad$. $\quad . \quad$. 4.25

4.2.2.5 Terrain and Geology . . . . . . . 4.25

4.2.2.6 Floodplain Management $\quad . \quad$. $\quad . \quad$. $\quad$. 4.26

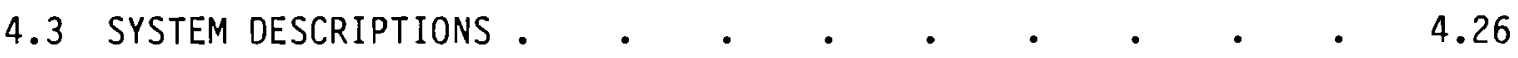

4.3.1 Waste Handling Facility $\quad . \quad$. $\quad . \quad$. $\quad . \quad 4.27$

4.3.1.1 Cask Receiving and Shipping . . . . . 4.35

4.3.1.2 Container Transfer and Packaging . . . 4.36

4.3.1.3 Contact Material Handling System . • . 4.37

4.3.2 Transfer and Storage of Contact-Handled Wastes -

TRUSS Facility

4.3.2.1 Structure . . . . . . . . . . 4.40

4.3.2.2 Material Handling and Storage . . . . 4.40

4.3.2.3 Retrieval . . . . . . . . . . 4.41

4.3.2.4 Storage Environment • . • . . . 4.42

4.3.2.5 Criticality Prevention . . . . . . 4.42

4.3.2.6 Radiation Monitoring . $\quad . \quad . \quad . \quad . \quad .4 .43$

4.3.2.7 Lighting . . . . . . . . . . . 4.43

4.3.2.8 Fire Detection and Suppression . . . . 4.43

4.3.2.9 Ventilation . . . . . . . . . 4.44

4.3.3 Transfer and Storage of Remote-Handled Wastes -
Casks . $. . \quad . \quad . \quad . \quad . \quad 4.44$

4.3.3.1 Surface Cask Storage • . . . . . . 4.48

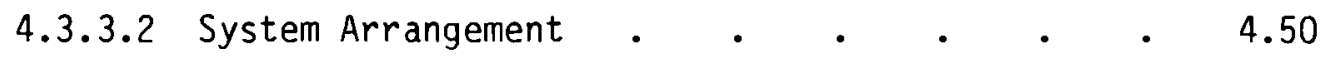

4.3.3.3 Component Description . . . . . $\quad$. 4.52

4.3.3.4 Cask Monitoring System . . . . . 4.53

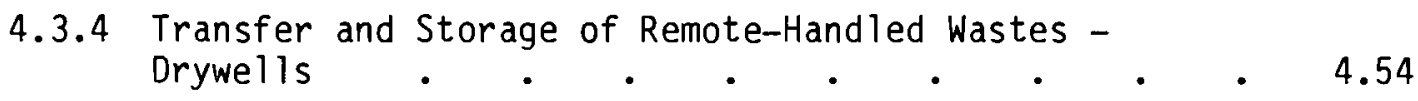


4.3.4.1 Transportation and Placement Systems $\quad$ • $\quad 4.54$

4.3.4.2 Drywell Storage Field . . . . . 4.58

4.3.4.3 Drywell Monitoring . $\quad$. $\quad$ • . 5.58

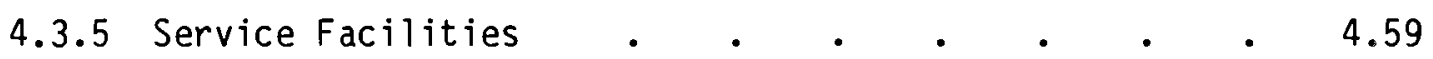

4.3.5.1 Administration Building . $\quad$ • . $\quad$ • $\quad$. 4.59

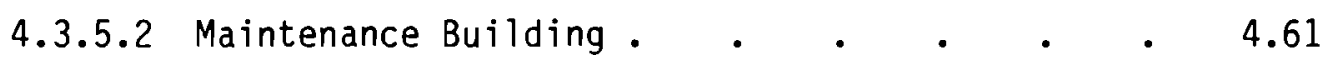

4.3.5.3 Material Warehouse Building . $\quad$ • $\quad$ • 4.61

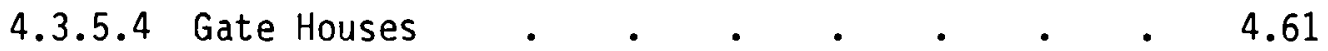

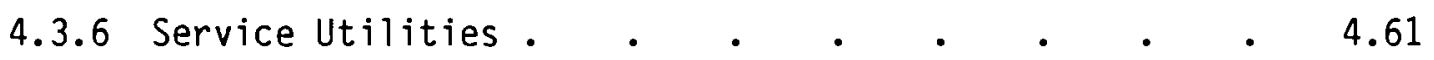

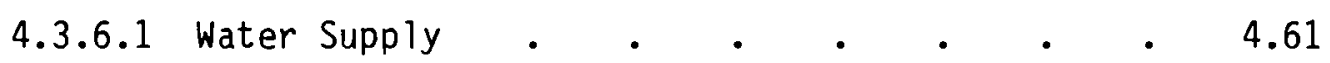

4.3.6.2 Electrical Power Systems . • . • . 4.62

4.3.6.3 Sanitary Waste Disposal System • . . . 4.62

4.3.6.4 Communications and Fire Alarm System . $\quad 4.62$

4.3.6.5 Radiation Monitoring and Surveillance . $\quad 4.63$

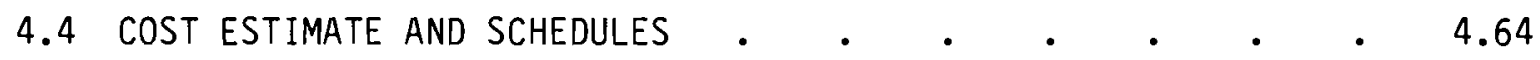

4.4.1 MRS/IS Facility Base Cost and Construction Schedule • $\quad 4.64$

4.4.2 Cost and Schedule: Reference Metal Storage Casks . 4.68

4.4.3 Cost and Schedule: Metal Cask Support Pads . . 4.68

4.4.4 Cost and Schedule: Concrete Casks . . . . 4.71

4.4.5 Cost and Schedule: Concrete Cask Support Pads . 4.71

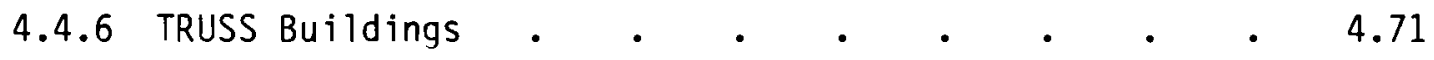

4.4.7 Annual Operating Expense . $\quad . \quad$. $\quad . \quad$. 4.74

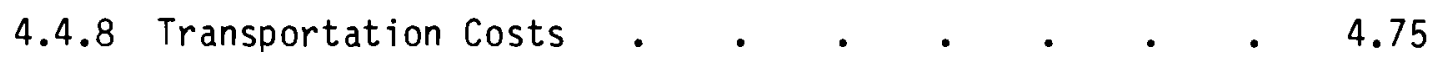

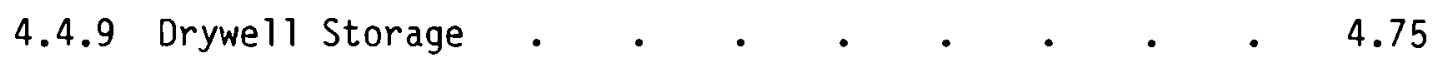

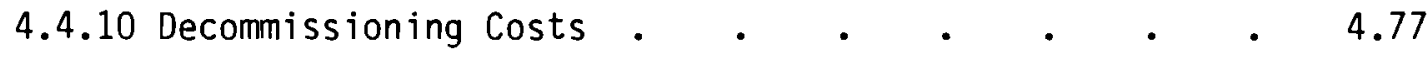




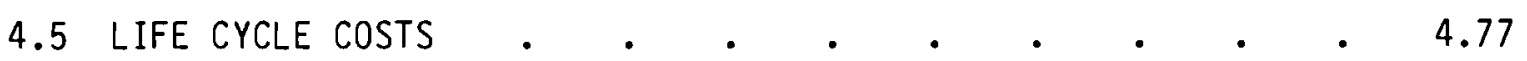

4.5.1 Reference Scenario Life Cycle Costs . . . 4.79

4.5.2 Delayed Reprocessing Scenario Life Cycle Costs . . 4.79

4.5.3 Delayed Disposál Scenario Life Cycle Costs . . . 4.84

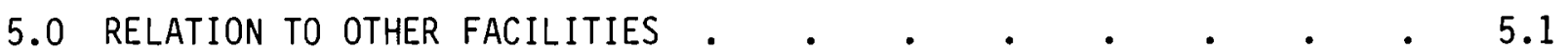

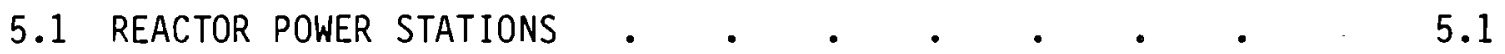

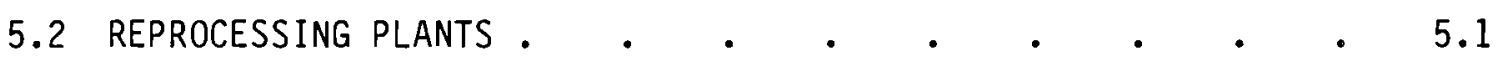

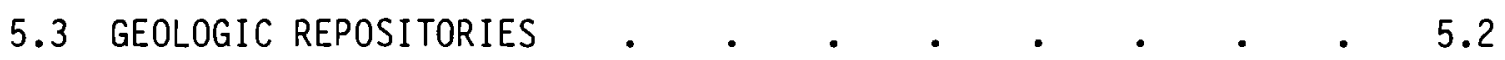

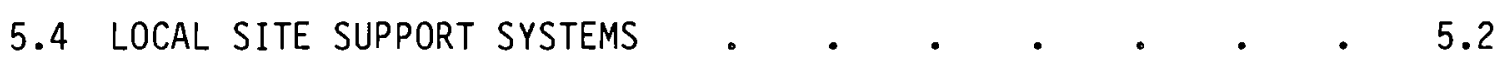

5.4.1 Transportation Services . . . . . . 5.2

5.4.2 Essential Services . . . . . . . . 5.4

5.4 .3 Other Support Services . $\quad$ • $\quad$ • $\quad$ • $\quad$ • 5.5

6.0 RESULTS AND RECOMMENDATIONS $\quad . \quad \ldots \quad$.

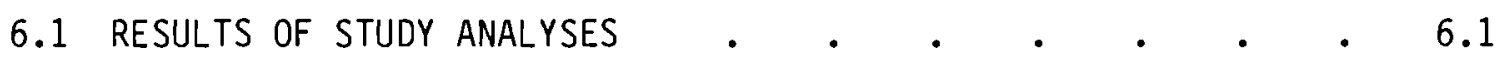

6.1.1 Comparison of Metal Storage Casks with Drywells . $\quad 6.4$

6.1.2 Possibilities for Cost Reduction . . . . . . 6.5

6.1.2.1 Consolidation of Spent Fuel Assembiles • $\quad 6.5$

6.1.2.2 Shipment in Large Metal Storage Casks . $\quad 6.5$

6.1.2.3 Combined Effect of Fuel Consolidation and
Storage Cask Transport . . . . . . . 6.6

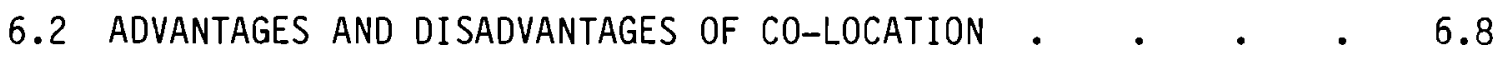

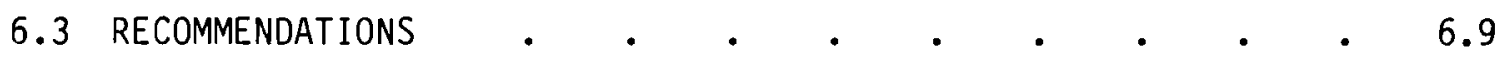

7.0 SENSITIVITY OF ESTIMATED COSTS TO VARIATIONS IN
CONCEPTS AND ASSUMPTIONS......

8.0 TECHNICAL STATUS/RESEARCH AND DEVELOPMENT REQUIREMENTS . $\quad$ • 8.1

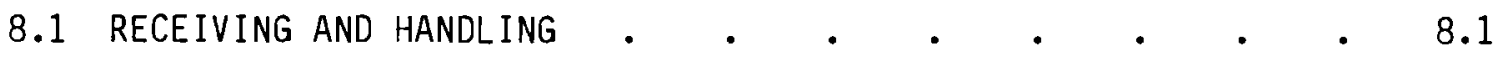




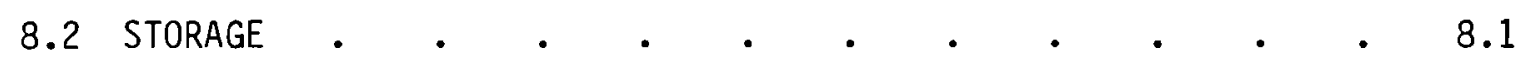

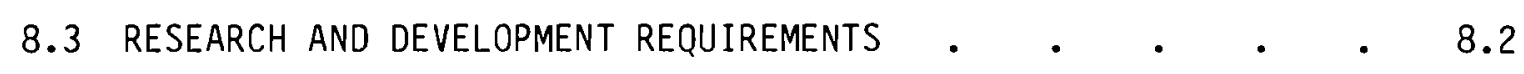
APPENDIX A - CONSIDERATIONS FOR MRS/IS COST EVALUATION • • • • A.1

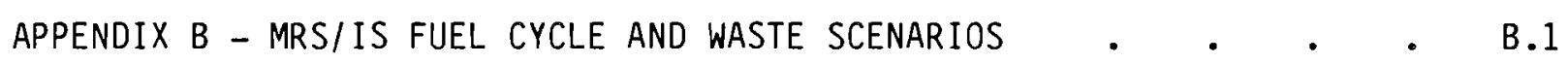

APPENDIX C - TRANSPORTATION INFORMATION •

APPENDIX D - GENERAL CRITERIA AND STANDARDS • • • • • • • • • D. 0.1 


\section{FIGURES}

2.1 Fractions of Total Undiscounted Life Cycle Cost

Attributable to Each Component of Cost, for

Each Scenario and Storage Alternative. . . . . . 2.6

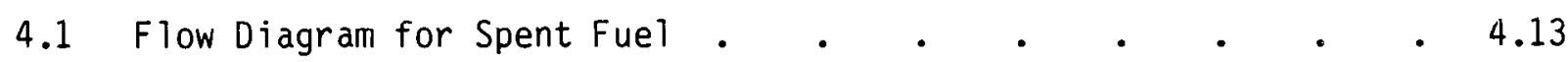

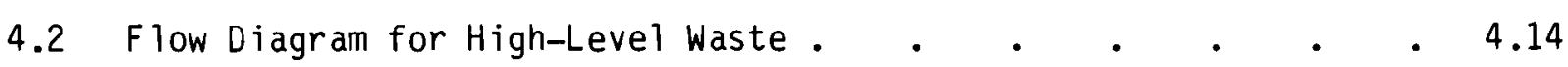

4.3 Flow Diagram for Remote Handled TRU Waste . $\quad$ • $\quad$ • $\quad$ e 4.15

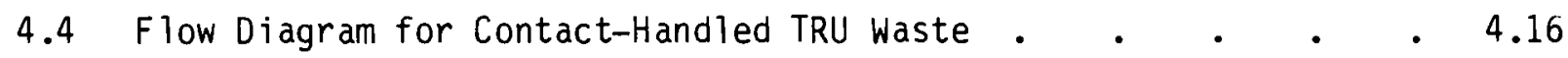

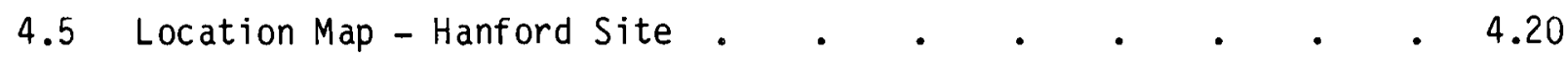

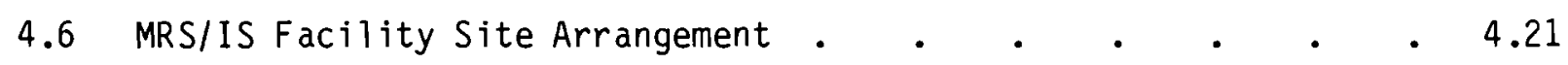

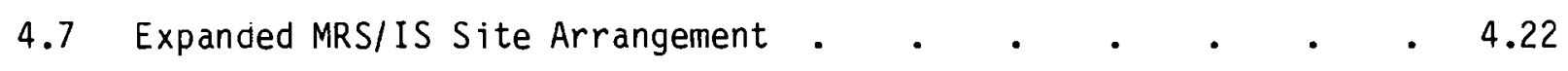

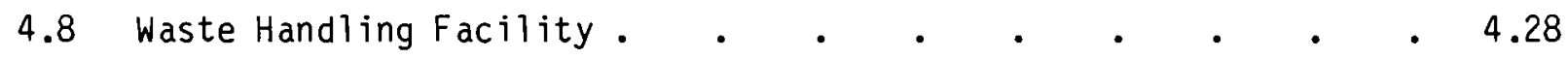

4.9 Waste Handling Facility - Ground Floor Plan . . . . . . 4.29

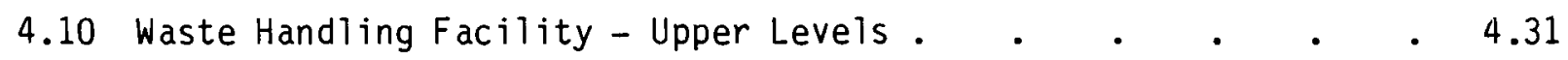

4.11 Waste Handling Facility - Sections and Elevations • • • 4.33

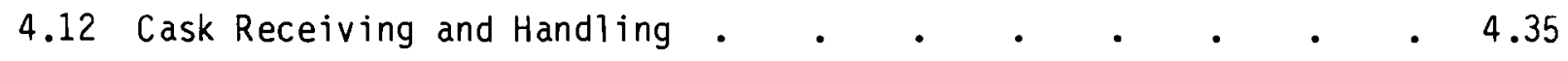

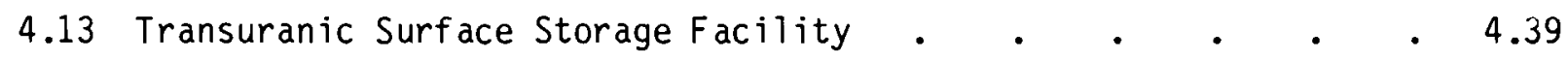

4.14 The Reference Passive Cooling Dry Storage Cask . . . . 4.45

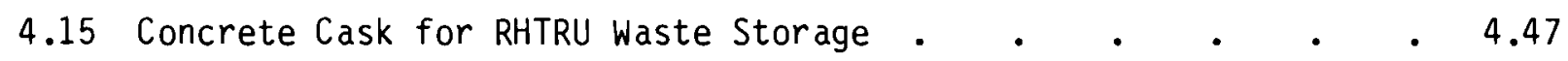

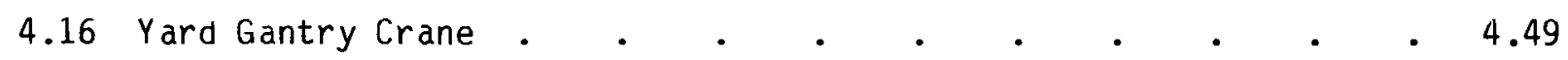

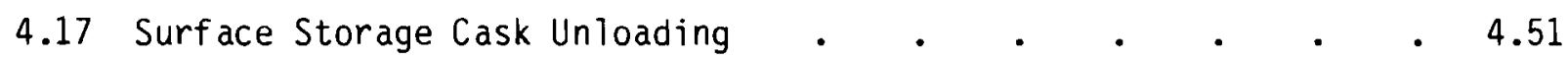

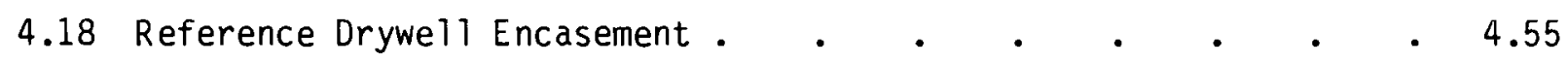

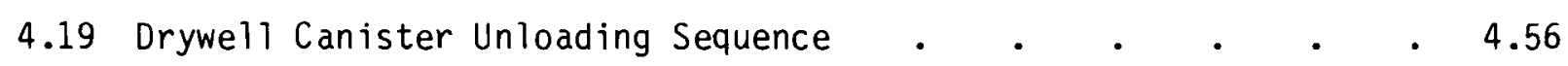

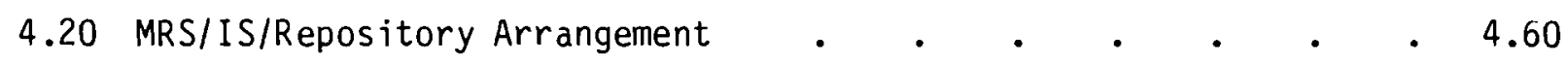

4.21 Postulated MRS/IS Facility Design and Construction Schedule • 4.65

6.1 Fractions of Total Undiscounted Life Cycle Cost Attributable to Each Component of Cost, for Each Scenario and Storage Alternative 


\section{TABLES}

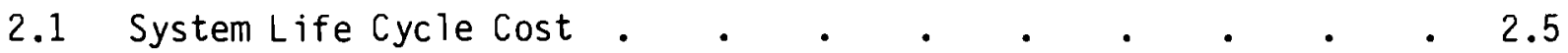

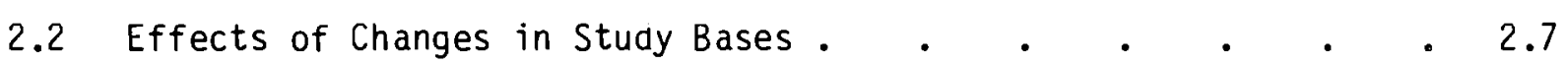

3.1 Reference Transportation Systems Selected for this Study • 3.10

3.2 Round-Trip Transportation Costs for Truck and Rail

Shipments of Spent Fuel and High-Level and

Transuranic Wastes . $. \quad . \quad . \quad . \quad . \quad . \quad . \quad . \quad$. 3.11

3.3 Reference Canister Sizes and Weights for Offsite

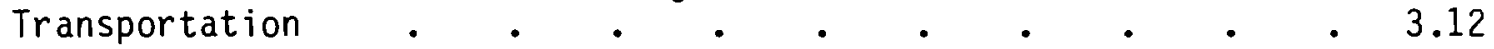

3.4 Annual Number of Incoming and Outgoing Shipments at the
MRS/IS Facility (Reference scenario) . . . . . . . 3.13

3.5 Annual Number of Incoming and Outgoing Shipments at the
MRS/IS Facility (Delayed Reprocessing scenario) • • • . . 3.14

3.6 Annual Number of Incoming and Outgoing Shipments at the

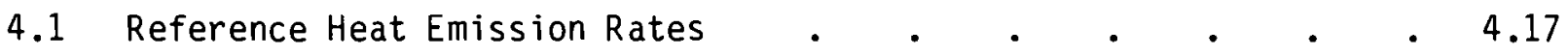

4.2 Reference Gamma Dose Rate and Neutron Emission Rates . • . 4.18

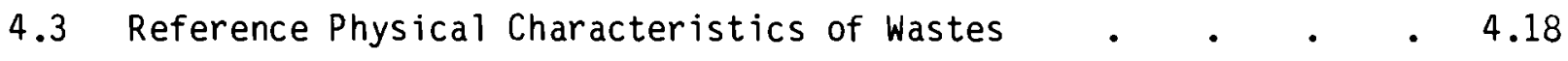

4.4 MRS Reference Scenario Storage Requirements . . . . . . 4.40

4.5 Reference Metal Storage Cask Design Data . . . . . . 4.46

4.6 Typical Surface Radiation Levels of Remote-Handles Material • 4.48

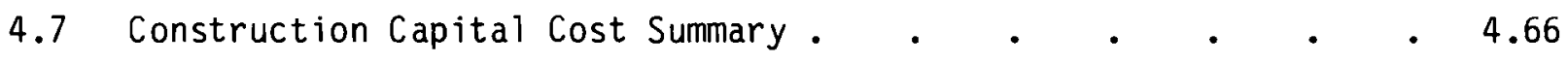

4.8 Cost Estimating Factors . . . . . . . . . . . . . . 4.67

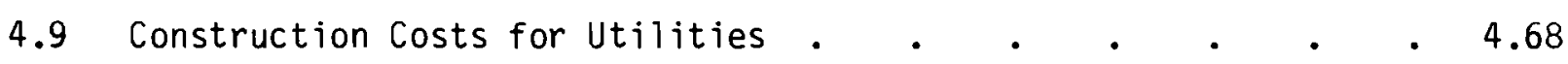

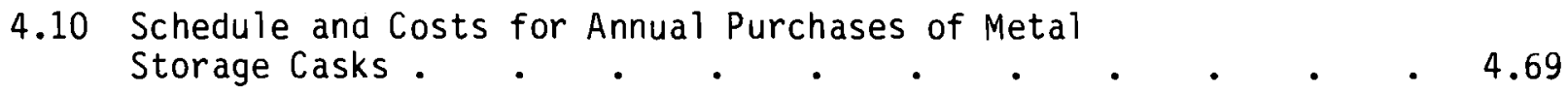

4.11 Schedule and Costs for Annual Construction of

Storage Pads and Storage Fields for Metal Casks 
4.12 Schedule and Costs for Annual Purchases of

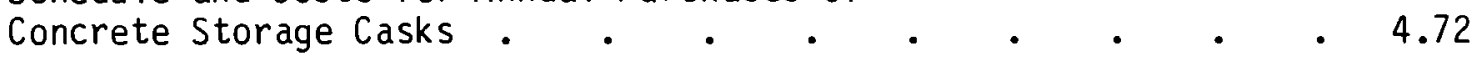

4.13 Schedule and Costs for Annual Construction of Storage Pads

and Storage Fields for Concrete Casks . $\quad$. . . . . 4.73

4.14 Yearly Operating Costs for the MRS/IS Facility . . . . . 4.74

4.15 Annual Transportation Costs for Each Scenario . . . . 4.76

4.16 Schedule and Costs for Annual Construction of Drywells

and Drywell Fields . $. \quad . \quad . \quad . \quad . \quad . \quad . \quad .48$

4.17 MRS/IS Facility Co-located With a Repository--Reference

Scenario, Life-Cycle Cash Flows: Cask Storage . $\quad . \quad$. 4.80

4.18 MRS/IS Facility Co-located with a Repository--Reference

Scenario, Life-Cycle Cash Flows: Drywell Storage . $\quad . \quad 4.81$

4.19 MRS/IS Facility Co-located With a Repository--Delayed

Reprocessing Scenario, Life-Cycle Cash Flows: Cask Storage $\quad 4.82$

4.20 MRS/IS Facility Co-located With a Repository--Delayed

Reprocessing Scenario, Life-Cycle Cash Flows: Drywell Storage • 4.83

4.21 MRS/IS Facility Co-located With a Repository--Delayed

Reprocessing Scenario, Life-Cycle Cash Flows: Cask Storage $\quad 4.85$

4.22 MRS/IS Facility Co-located With a Repository--Delayed

Disposal Scenario, Life-Cycle Cash Flows: Drywell Storage . $\quad 4.86$

5.1 Items and Functions Shared or Used by Both MRS/IS

Facility and the Repository . $. \quad . \quad . \quad . \quad . \quad 5.3$

6.1 Components of Life Cycle Costs, Percentages and Totals . $\quad 6.2$

6.2 Undiscounted and Discounted Life Cycle Costs for the

Scenarios and Storage Alternatives Studied . • . 6.4

6.3 Effect of Fuel Assembly Consolidation on MRS/IS

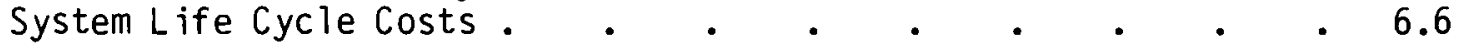

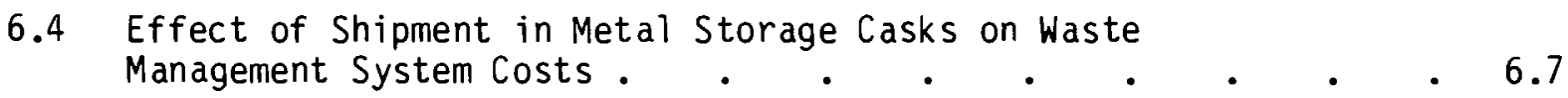

6.5 Combined Effect of Fuel Consolidation and Shipment in
Storage Casks on Waste Management System Costs . . . . . $\quad 6.7$

7.1 Estimated Life Cycle Costs and Possible Variations . . $\quad$. 7.2 


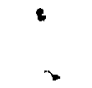




\subsection{INTRODUCTION}

Until 1975, commercial power reactor owners had planned to store spent fuel at the reactor for a short period prior to shipment to a reprocessing plant. Reactors built in that era generally has storage space for only one or two batch discharges of spent fuel plus a full core discharge capability. However, changes in recent years in federal policies regarding reprocessing and/or disposal of spent nuclear reactor fuel have produced delays in the development of fuel reprocessing plants and deep geologic disposal facilities. As a result, many nuclear power plants are faced with the possibility of shutdown due to lack of spent fuel storage capacity. In recognition of this problem, legislative initiatives are underway in Congress to provide appropriate storage and disposal facilities. In response to these legislative initiatives, the Department of Energy (DOE), through its Office of Nuclear Fuel Cycle, has established a program to examine the various alternatives for storage of spent nuclear fuel, solidified high-level wastes $(H L W)$, and transuranic (TRU) wastes until an appropriate deep geologic repository is available for disposal of these wastes. One of these alternatives, a monitored retrievable storage/interim storage (MRS/IS) facility built on the site of a future repository, is the subject of this study.

The storage facility evaluated in this study employs dry handling and storage methods, utilizing a large hot cell facility, metal casks or drywells, concrete casks, and a surface warehouse.

The study objectives, scope, and study bases are presented in Section 3. A preconceptual design for the facility is given in Section 4, together with estimates of construction, operating, and life cycle costs. The relationship of the MRS/IS facility to other parts of the nuclear fuel cycle and to local site support systems is discussed in section 5 . The results of the cost analyses, the advantages and disadvantages of co-location with a repository, and recommendations for further action are given in Section 6 . The sensitivity of the estimated life cycle costs to variations in the study bases is examined in Section 7, and the status of system component development and areas needing further research and development are discussed in Section 8. 


\subsection{SUMMARY}

The Office of Nuclear Fuel Cycle of the Department of Energy (DOE) has established a program to examine the various alternatives for monitored retrievable storage (MRS) and interim storage (IS) of spent nuclear fuel, soliaified high-level waste (HLW), and transuranic (TRU) waste until such time as appropriate geologic repository/repositories are available. The alternatives being examined are: 1) a facility co-located with a reprocessing plant, 2) a facility located separate from any other facilities, and 3) a facility co-located with a geologic repository. The facility examined in this study is located on the site where a geologic repository is to be developed, and it becomes the principal surface facility of the repository when the repository is opened, thus avoiding duplication of the facilities.

The objectives of this study are to develop a preconceptual design for an MRS/IS facility to be co-located on the same site as a geologic repository, to estimate the life cycle costs, and to examine the transportation, licensing, safety, and environmental issues associated with such a facility.

\subsection{STUDY BASES}

A number of bases and assumptions are made to facilitate the analyses of the MRS/IS/Repository concept. These include:

1. Construction, operation, and decommissioning of the facility are major federal actions and are subject to the requirements of the National Environmental Policy Act (NEPA); the facility is subject to licensing by the Nuclear Regulatory Commission.

2. The facility utilizes passively cooled ary storage devices (metal casks, drywells) for storing spent fuel and canisters of HLW, concrete casks for storing remote-handled TRU (RHTRU) wastes, and a warehouse for storing contact-handled TRU (CHTRU) wastes.

3. Transport of the radioactive wastes is accomplished using existing or currently designed truck and rail shipping containers.

4. A11 costs are based on mid-1982 prices, with future expenditures discounted 2 percent per year from mid-1982. 
5. The facility is assumed to have the capability to receive, package as necessary, store, retrieve, and ship radioactive waste materials either offsite or to the co-located repository.

6. The highly radioactive materials (spent fuel, HLW, and RHTRU) are assumed to be from reactor fuel that has cooled for at least

10 years since discharge from a reactor.

The types and quantities of radioactive wastes to be handled by the facility are defined by three principal scenarios: reference, delayed reprocessing, and delayed disposal. In all scenarios, the MRS/IS facilities do not receive any material for storage until 1990. Prior to 1990, spent fuel is assumed to be stored at reactor sites.

In the Reference scenario, reprocessing plants with capacities of 1500 , 1500,3000 , and 3000 metric tons of heavy metal (MTHM) per year are placed in operation in the years 1989, 2000, 2005, and 2010, respectively. Geologic repositories with capacities of 1800 MTHM per year in each of the first 5 years of operation and 3000 MTHM per year in each of the succeeding 21 years of operation are postulated to be placed in operation in the years 1998, 2002, and 2015.

In the Delayed Reprocessing scenario, the initial operation of the reprocessing plants is delayed 10 years.

In the Delayed Disposal scenario, the initial operation of the repositories is delayed 10 years. All spent fuel is postulated to be reprocessed, with only solidified HLW and TRU wastes placed in the repositories.

Transportation of the radioactive materials is accomplished using presently available or designed shipping containers, with the volume of material divided evenly between truck and rail transport systems. Large numbers of shipments are required. The maximum numbers of truck and rail shipments made annually to and/or from the facility are: in the Reference scenario, 864 and 142; in the Delayed Reprocessing scenario, 3473 and 454; and in the Delayed Disposal scenario, 2445 and 579 . The costs of transportation 
considered in this study are just those incremental costs attributable to utilizing the MRS/IS facility, not the total transport costs associated with the waste management system.

\subsection{CONCEPTUAL FACILITY CHARACTERISTICS}

The facility considered in this analysis is postulated to be located on the Hanford Site, and has reasonable access to highways and rail-track, electrical service, process water supplies, heavy equipment and transportation services, and security services available on the Site.

The site for the MRS/IS facility is postulated to be located west of the 200 West area, and occupies about 400 acres of 1 and. In comparison, an area of about 550 acres is projected to be required for the surface support facilities for the geologic repository.

The reference MRS/IS facility consists of three principal sections: the Waste Handling Facility (WHF), the storage areas, and the support facilities, with appropriate interfaces. The WHF encompasses the receiving and shipping stations for transport casks, the shielded cells for inspection, encapsulation (if needed), container decontamination, and delivery to the onsite transport system of the received radioactive materials. All materials are received dry and are maintaineo dry throughout the handling and storage operations.

The storage areas include large fenced areas containing support pads for metal storage casks or drywells, depending upon which concept is used for storage of spent fuel and HLW, storage areas containing support pads for concrete storage casks used in storing RHTRU wastes, and large concrete warehouse(s) for storage of CHTRU wastes. Each of the storage systems has. provisions for monitoring each of the system's containment barriers for detection of release of radioactive material. A reference metal storage cask (REA 2023) and a reference drywell are postulated for this analysis.

Onsite transporter systems are employed to transfer the spent fuel, HLW, and RHTRU from the WHF to the storage areas. For the metal and concrete casks, a tractor-trailer unit is used to move the loaded casks from the WHF to the storage areas, where a large gantry crane places the casks onto the 
storage pads. For the drywell, a shielded transporter is used which couples with the top of the drywell for insertion of the sealed canister containing spent fuel or HLW.

CHTRU wastes are received at the TRU Surface Storage (TRUSS) facility and stored using normal warehousing equipment. The TRUSS building is constructed of precast concrete and has appropriate ventilation and monitoring systems to minimize the potential for release of radioactive materials to the environment. The TRU wastes stored in the TRUSS facility are assumed to have been concreted within their shipping and storage containers to reduce the potential for dispersion of TRU materials in the event of an accident that breaches the containers.

The conventional support facilities include an administration building, maintenance building, material warehouse, gate houses, sanitary disposal system, water and electrical supply systems, and communication and fire alarm systems.

\subsection{CONSTRUCTION SCHEDULE AND COST ESTIMATES}

Design of the MRS/IS facility is estimated to require about 30 months, with construction initiated about 15 months after the start of the design work. Construction is estimated to require about 48 months. Elapsed time from authorization to initial operation is postulated to be about 66 months.

The total cost of the basic facility, including the initial storage areas and warehouse, is estimated to be $\$ 178$ million in mid-1982 dollars. Direct construction costs are about $\$ 105$ million, with engineering, indirect, and other costs and contingencies comprising an additional $\$ 73$ million.

\subsection{SYSTEM LIFE CYCLE COST}

The life cycle cost of an MRS/IS facility co-located with a repository is comprised of the capital construction cost, capital and operating costs during operation, and decommissioning costs. The direct construction costs are estimated to be $\$ 178 \mathrm{million}$. Operating costs are estimated to be about $\$ 11$ million per year, plus canister materials when using drywells. 
Purchases of metal storage casks during the lifetime of the facility are estimated to cost from $\$ 306$ million to $\$ 1.768$ billion, depending upon the scenarios. Purchases of drywells in lieu of metal casks are estimated to cost from $\$ 90$ million to over $\$ 509$ million. Purchases of concrete storage casks are estimated to cost from about $\$ 42$ million to over $\$ 243$ miliion.

Decommissioning of the MRS/IS facility is limited to the decontamination and disposal of the storage casks and/or drywells and removal of the storage pads. The rest of the facility becomes part of the repository system and would be decommissioned when the repository is closed. It is anticipated that, at least when metal casks are used, the salvage value of the casks will exceed the other costs of decommissioning. Hence, no net cost is assigned to decomissioning in this study.

The life cycle cost of the MRS/IS system is summarized in Table 2.1 for the three principal scenarios, both undiscounted and discounted at the rate of 2 percent per year.

The fractions of total undiscounted life cycle cost attributable to each component of cost are illustrated in Figure 2.1 for each of the three principal scenarios ana storage alternatives.

TABLE 2.1. System Life Cycle Cost(a)

\begin{tabular}{lll}
$\begin{array}{l}\text { Reference } \\
\text { Scenario }\end{array}$ & $\begin{array}{c}\text { Delayed } \\
\text { Reprocessing }\end{array}$ & $\begin{array}{l}\text { Delayed } \\
\text { Disposal }\end{array}$ \\
\hline
\end{tabular}

Undiscounted:

$\begin{array}{llll}\text { Metal Casks } & 0.731 & 2.257 & 2.487 \\ \text { Drywells } & 0.518 & 1.973 & 1.235\end{array}$

Discounted:

$\begin{array}{llll}\text { Metal Casks } & 0.578 & 1.592 & 1.661 \\ \text { Drywells } & 0.412 & 1.376 & 0.868\end{array}$

(a) Billions of dollars. 


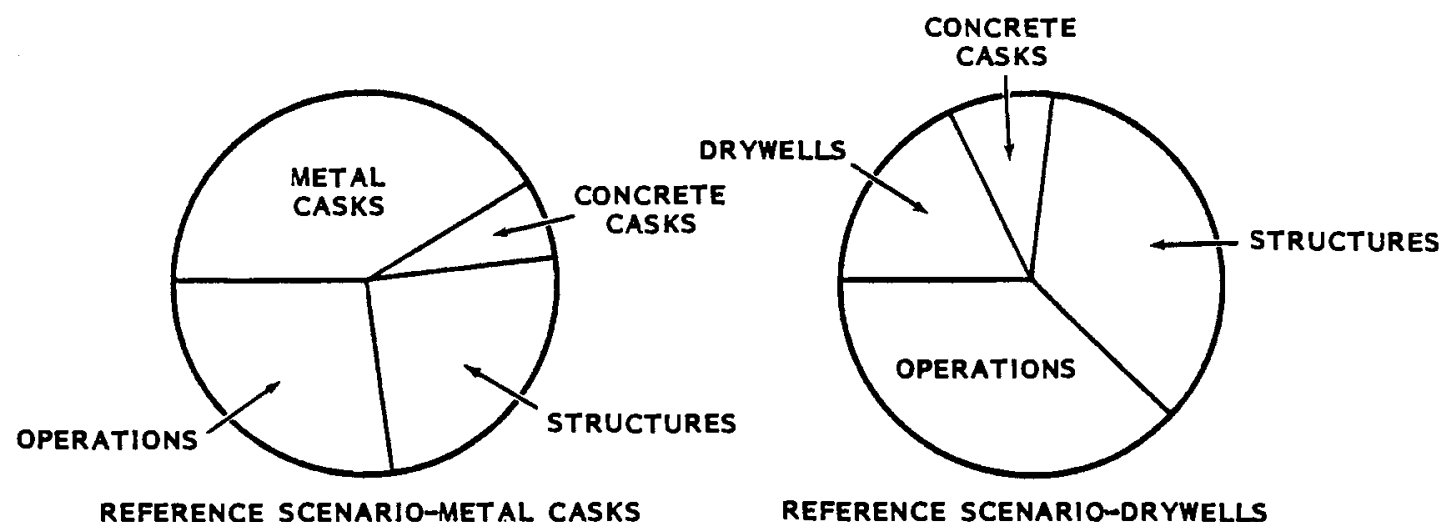

REFERENCE SCENARIO-METAL CASKS

REFERENCE SCENARIO DRYWELLS

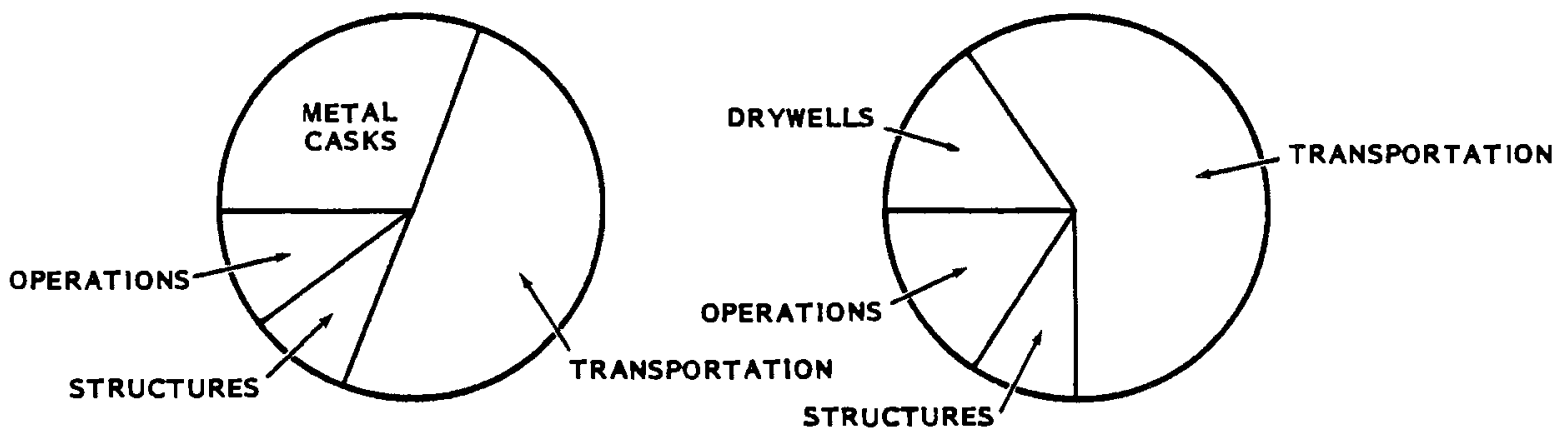

DELAYED REPROCESSING-METAL CASKS

DELAYED REPROCESSING-DRYWELLS

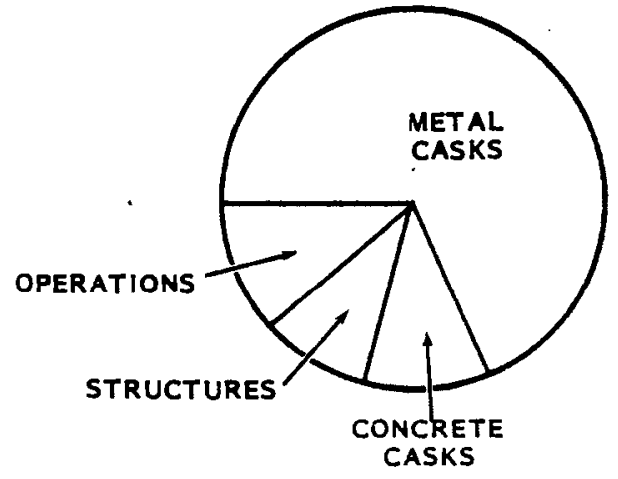

DELAYED DISPOSAL-METAL CASKS

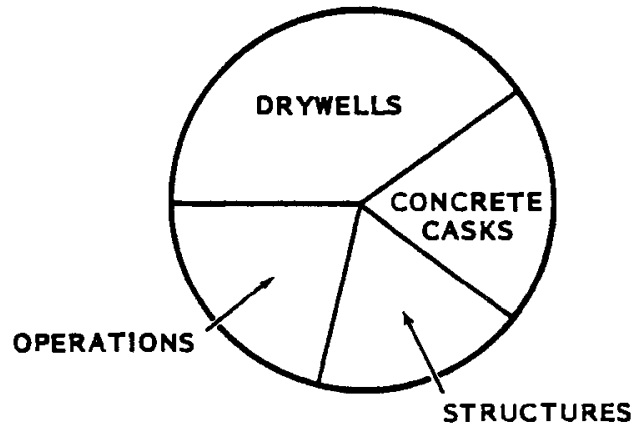

DELAYED DISPOSAL-DRYWELLS

FIGURE 2.1. Fractions of Total Undiscounted Life Cycle Cost Attributabie to Each Component of Cost, for Each Scenario and Storage Alternative 


\subsection{SENSITIVITY OF COSTS TO CONCEPTS AND ASSUMPTIONS}

As shown in Figure 2.1, two components of cost, transportation (in the Delayed Reprocessing scenario) and metal casks or drywells, contribute most of the cost and are logical candidates for examination for cost reduction.

If drywells are utilized instead of metal casks, the life cycle cost is reduced by $29.1,12.2$ and 50.3 percent for the Reference, Delayed Reprocessing, and Delayed Disposal scenarios, respectively.

If spent fuel assemblies are disassembled and consolidated into closely packed containers at the reactor sites prior to shipment, the number of shipments is cut in half, as is the number of casks needed to store spent fuel.

The use of larger shipping casks (i.e., the reference metal storage cask) also greatly reduces the number of shipments required. The effects of these changes in the study bases are summarized in Table 2.2, for the base case of using the reference metal cask.

TABLE 2.2. Effects of Changes in Study Bases

\begin{tabular}{|c|c|c|c|}
\hline & $\begin{array}{l}\text { Reference } \\
\text { Scenario } \\
\end{array}$ & $\begin{array}{c}\text { Delayed } \\
\text { Reprocessing } \\
\end{array}$ & $\begin{array}{l}\text { Delayed } \\
\text { Disposal } \\
\end{array}$ \\
\hline $\begin{array}{l}\text { Undiscounted Life Cycle Cost } \\
\text { ( } \$ \text { Billions) }\end{array}$ & 0.731 & 2.294 & 2.487 \\
\hline $\begin{array}{l}\text { Fuel Consolidation at } \\
\text { Reactor Sites } \\
\text { (\% change) }\end{array}$ & & -41.4 & \\
\hline $\begin{array}{l}\text { Ship in Storage Casks } \\
(\% \text { change })\end{array}$ & -36.2 & -50.2 & -45.3 \\
\hline $\begin{array}{l}\text { Fuel Consolidation and } \\
\text { Shipment in Storage Casks } \\
\text { (\% change) }\end{array}$ & -36.2 & -66.5 & -45.3 \\
\hline
\end{tabular}

\subsection{CONCLUSIONS AND RECOMMENDATIONS}

Several conclusions can be drawn from the results of this study. First, co-locating the MRS/IS facility with a repository has several advantages. Overall waste management costs can be reduced by eliminating the duplication 
of facilities that would occur if the MRS/IS facility and the repository were located separately. Amortization of the capital expenditures on facilities would take place over a longer period of time, perhaps 40 years rather than the 15- to 20-year life of the MRS/IS facility, thereby reducing total system costs. In addition, the stored materials would be transferred directly from storage to the repository, without leaving the site, thereby minimizing the potential for transportation accidents and the possible exposure of the public resulting from such accidents.

Second, the likely cost of an MRS/IS system is large, $\$ 0.5$ to $\$ 2.5$ billion. Thus, all avenues available for reducing costs should be explored. Based on the unit costs assumed for the reference metal cask and for the reference drywell, the drywell is less expensive by from 12 to 50 percent. Use of fuel consolidation and larger shipping casks has the potential to reduce system costs by from 36 to 66 percent.

Third, the basic technology needed to construct and operate an MRS/IS facility is generally well-developed. Additional information on allowable fuel element cladding temperatures in dry storage would be very helpful, as would the development of validated heat transfer calculational codes for predicting cladding temperatures. Also, information to assist in the licensing of large storage casks for use in shipment as well as in storage would be very useful.

Fourth, a review of the scenarios examined in this study and the associated transportation costs suggests that the waste management system might be considerably more cost-effective if there were two MRS/IS facilities, one located at the reprocessing plant to hold spent fuel for reprocessing, and one located at the repository to store HLW and TRU wastes until the repository is placed in operation. This situation is not examined in this study, but should be evaluated before establishing a site-specific program.

Finally, in view of the massive quantities of radioactive material to be storea and the time duration of the storage, the use of a water pool for storage of spent fuel, HLW, and RHTRU might be cost-effective. A detailed analysis of a water pool facility comparable with the analysis presented in this study for dry storage facilities should be made before embarking on the construction of a cask or drywell storage facility.

$$
2.8
$$




\subsection{OBJECTIVES, SCOPE, AND BASES OF STUDY}

The monitored retrievable storage/interim storage (MRS/IS) facility is conceived as a government-owned, contractor-operated facility for providing temporary storage for spent fuel and/or reprocessing wastes. The MRS/IS program would provide federal contingency capability for storing spent nuclear fuel until reprocessing facilities can eliminate the need for such storage, and woula provide federal capability for storing solidified high-level wastes (HLW) and transuranic (TRU) wastes until appropriate waste disposal repositories become available. It is assumed that the actual repository will not exist when the MRS/IS facility is built. Therefore, consideration of facility capabilities that could initially serve the needs of the MRS/IS facility and subsequently serve the needs of the repository is an important aspect of this study, in terms of projecting life cycle costs. Similarly, support services, in the form of existing roads, railroads, and other utility services, and extensions of those services, as they apply to the MRS/IS/Repository, are also important considerations.

\subsection{OBJECTIVES AND SCOPE}

The objectives of this stuay are to: 1) develop a preconceptual design for an MRS/IS facility to be co-located on the same site as a geologic repository, 2) to estimate the life cycle costs, and 3) to examine the transportation, licensing, safety and environmental issues associated with such a facility.

The scope of this study is limited to consideration of an MRS/IS facility that is located on a site with a geologic repository. The functional requirements of the facility include the ability to receive, handle, transfer, store, and ship spent reactor fuel, solidified HLW, and transuranic wastes, both contact-handled (CHTRU) and remote-handled (RHTRU). Storage concepts considered are: 1) dry storage casks, 2) drywells, and 3) warehouse storage for CHTRU. The MRS/IS facility is to be constructed on a modular basis, with additional storage space developed annually to accommodate the quantities of waste projected to need storage each year. All wastes are to be stored in a retrievable manner. 


\subsection{STUDY BASES AND PLANNING ASSUMPTIONS}

To facilitate comparison of the study results, a number of generic assumptions have been made to provide a common basis for the individual site studies. These are: 1) the facility is located and constructed so it can also serve as the basic surface facility for a permanent geologic repository, and 2) facility capabilities and capacities are based on the assumption that no additional pool expansions or dry storage at reactors are available or used. Basic assumptions are identified in the following subsections.

\subsubsection{Regulatory Considerations}

Building and operating an MRS/IS facility is a major action by the federal government and is subject to the requirements of the National Environmental Policy Act (NEPA). The facility is also subject to licensing by the Nuclear Regulatory Commission (NRC).

The interim storage facility will be decommissioned after its contents are transferred to permanent repositories.

\subsubsection{Functional Capabilities}

The facility has the capability to receive materials from reactors and reprocessing plants and to ship material to reprocessing plants as well as to repositories. The facility also has the capability to repackage any material received from offsite as well as to repackage any onsite material as required for offsite transport. In addition, it has the capability to receive and to ship materials by both rail and highway vehicles.

Casks used for shipment of material to and from the MRS/IS facility are either those currently licensed for the shipment of irradiated commercial fuel assemblies and TRU wastes or are newly developed ones similar in design and handling requirements. One or more of the casks has the capability of transporting either spent fuel or solidified commercial high-level waste.

\subsubsection{Storage Systems}

The facility will accept both assembled and disassembled commercial pressurized water (PWR) and boiling water (BWR) reactor fuel that can be identified and is known to comply with certain specified requirements. 
The facility will accept identifiable solidified high-level waste forms that are known to comply with specified heat, containment and physical condition requirements.

The facility will accept identifiable transuranic wastes that comply with specified contents, packaging and physical condition requirements.

Storage is provided for spent fuel, solidified commercial high-level wastes, and transuranic wastes only until disposal in the repository is available.

\subsubsection{Economic Bases}

Al1 costs developed in this study are presented in terms of constant, unescalated mid-1982 dollars, including expenditures that are made in future years. Interest rates and inflation or escalation rates are difficult to predict, but the difference between interest and inflation rates tends to be around 2 percent, essentially independent of the actual values of the individual interest and inflation rates. Therefore, in developing the present values of future expenditures in this study, a discount rate of 2 percent is used.

Costs are developed in terms of expenditures per year, covering the construction, operation and decommissioning of the MRS/IS facility. The costs of transporting the radioactive materials from their points of origin to the MRS/IS facility are developed separately, but are included in the total life cycle cost of the system. Each total annual expenditure is discounted to mid-1982. The discounted annual expenditures are summed to obtain the present values of the lifetime expenditures for the facility, thus permitting comparisons between design concepts that may have different expenditure patterns.

A detailed discussion of the methods used in this study to develop the estimates of capital, operating, and decommissioning costs is presented in Appendix $A$ of this report. 


\subsection{LEGISLATIVE REQUIREMENTS}

A number of bills are presently under consideration by Congress which deal with the topics of interim (emergency) storage of commercial spent nuclear fuel, monitored retrievable storage of spent fuel, solidified high-level wastes, transuranic wastes, and permanent disposal of these nuclear wastes in deep geologic repositories.

Each of the bills under serious consideration (S.1662, H.R.3809, H.R.6589) has provisions for the establishment of repositories, mechanisms to assure full recovery of the costs of storage and disposal operations from the waste generators, and procedures to assure that interested states and Indian tribes can be involved in the siting process. Several of the proposed bills differ regarding who has title to the radioactive material while in storage prior to final disposal in a repository. The federal government takes title in one bill ( $\mathrm{S} .1662)$, and the waste generators retain title in the other two bills (H.R.3809, H.R.6589).

Specific provisions unique to interim storage, monitored retrievable storage, and transuranic waste storage are discussed in the following subsections.

\subsubsection{Interim (Emergency) Storage of Spent Fuel}

The bills contain language that would make licensing of additional storage capacity at existing reactor sites easier, by eliminating some of the issues that would otherwise have to be considered (availability or desireability of alternatives, the need for power from the reactor, any issues relating to reactor operation, etc.).

The capacity of the interim (emergency) storage facilities would be limited [1700 (H.R.3809) or 2800 (S.1662) metric tons], would be exempt from licensing if located at an existing federal site (H.R.3809), and would not be a major federal action as defined in the NEPA (H.R.3809). The operation of an interim (emergency) storage facility is limited to 5 to 7 years (President's letter), or 8 to 12 years (S.1662). 
The interim (emergency) storage provisions are intended to provide a way to avoid shutdown of operating power reactors in case full core discharge capability is lost as the quantities of fuel in storage pools approach the pool's capacity. This type of storage is intended as a very limited effort, of relatively short duration. Longer-term storage of radioactive materials such as spent fuel, solidified high-level waste, and transuranic waste would be provided for by monitored retrievable storage facilities, which are discussed in the next subsection.

\subsubsection{Monitored Retrievable Storage}

The DOE is directed to submit to Congress within 1 year of passage of the enabling legislation a proposal to develop one or more MRS facilities. This proposal is to include site-specific designs, specifications and cost estimates, and a plan for integrating the MRS facilities with the deep geologic disposal repositories also mandated by the legislation.

In all cases, an environmental assessment (EA) is required at the time the proposal is submitted, with an environmental impact statement (EIS) to be issued before construction is initiated. The MRS must be licensed by the NRC. During the NEPA and licensing processes, issues nomally considered, such as the need for the facility, alternate sites, and alternate designs, need not be considered.

No specific instructions are given in the various House bills regarding the capacity of an MRS facility. However, in the Senate bill (S.1662), until a second repository is in operation, a limit of 70,000 metric tons of spent fuel is placed on the combined capacity of an MRS facility and the first repository when located within 50 miles of each other.

Similarly, no clearly defined limitation is proposed for the duration of MRS operations. Instead, the MRS $f$ acilities are to remain in service until geologic repositories are available.

\subsubsection{Storage of Transuranic Wastes}

The storage of transuranic wastes is addressed specifically in the House bills, with the intent of storing these materials until a geologic repository is available. If located on a federal site, the storage facility would not be subject to licensing or the NEPA. 
Several time constraints are proposed in the pending legislation: 1) the NRC shall issue regulations governing TRU storage within two years of passage; 2) DOE shall cease accepting TRU wastes for storage when an appropriate repository is available, or 6 years after NRC has issued their regulations, whichever occurs first. Thus, TRU wastes would be accepted for storage for a maximum of 8 years following passage of the enabling legislation.

\subsection{FUEL CYCLE SCENARIOS}

Three principal scenarios and two alternative scenarios (developed in Appendix B) are examined for their impact on the life cycle cost of the MRS/IS facility co-located with a repository. The storage facility is postulated to begin operation in 1990, with spent fuel requiring storage prior to that time being stored at reactor sites.

In the Reference scenario, reprocessing plants are postulated to come on-line in the years 1989, 2000, 2005, and 2010, with capacities of 1500, 1500, 3000 , and 3000 metric tons of heavy metal (MTHM) per year, respectively. Geologic repositories are postulated to be placed in operation in the years 1998, 2002, and 2015, with capacities of 1800 MTHM per year in each of the first 5 years of operation and 3000 MTHM per year in the succeeding 21 years of operation.

In the Delayed Reprocessing scenario, startup of each of the reprocessing plants is delayed 10 years, to the year 1999, 2010, 2015, and 2020, with the repository schedule remaining the same as that of the Reference scenario.

In the Delayed Disposal scenario, reprocessing starts in 1989 , as in the Reference scenario, but opening of the repositories is delayed 10 years to the years 2008, 2012, 2015, and 2025.

The alternative scenarios, Early Disposal and Delayed Disposal with No Reprocessing, represent the lower- and upper-bound situations for storage of material in the MRS/IS facility, and are not analyzed in this study.

In the three principal scenarios it is assumed that all spent fuel is eventually reprocessed. It is also assumed that there is only a single MRS/IS facility serving the U.S. nuclear power industry. Thus, in the Delayed 
Reprocessing scenario, many spent fuel assemblies $(\sim 30,000)$ are stored for an extended period of time ( 30 years), but little or no reprocessing waste must be handled. Conversely, in the Delayed Disposal scenario, no spent fuel is stored, but massive quantities of reprocessing wastes are stored for an extended time period.

For the Reference scenario, the maximum number of incoming $H L W$ canisters that must be handled annually is 700 in the years 1992 through 1997. The maximum numbers of incoming remote-handled transuranic (RHTRU) canisters, RHTRU drums, contact-handled transuranic (CHTRU) drums, and CHTRU boxes that must be handled annually are 549, 698, 4868, and 41, respectively, in the years 1992 through 1997. The maximum inventory of HLW and TRU wastes occurs in the year 1997, just prior to the opening of the repository, with $4900 \mathrm{HLW}$ canisters, 3845 RHTRU canisters, 4299 RHTRU drums, 34,076 CHTRU drums, and 286 CHTRU boxes.

For the Delayed Reprocessing scenario, the maximum number of spent fuel assemblies that must be handled annually is 9590, in the year 2016, when the fuel is being shipped to the reprocessing plants. The maximum inventory of spent fuel assemblies stored in the MRS/IS facility is 26,981 , in the year 19y7. The bulk of these assemblies remain in storage until the year 2012 when reprocessing plant capacity exceeds the output from the operating reactors. Since the repositories will be in operation before any HLW or TRU wastes are created, all of these materials will go directly to the repository.

For the Delayed Disposal scenario, the maximum number of incoming HLW canisters that must be handled annually is 2,334 in the year 2007 . The maximum numbers of incoming RHTRU canisters, RHTRU drums, CHTRU drums, and CHTRU boxes that must be handled annually are 1,830, 2,327, 16,227, and 135, respectively, in the year 2007. The maximum inventory of HLW and TRU wastes occurs in the year 2016, just following the opening of the third repository, with 29,598 HLW canisters, 22,157 RHTRU canisters, 28,169 RHTRU drums, 192,923 CHTRU drums, and 1,643 CHTRU boxes.

The repository co-located with this MRS/IS facility is assumed to come on-line in 1998 for both the Reference and the Delayed Reprocessing scenarios. Since all of the original MRS/IS facility except the interim 
storage areas would then be serving and supporting the underground repository, there would be no further activities related to interim storage. The removal of the wastes stored in the various interim storage areas and their transfer to the repository are assumed to be parts of the repository operation. As indicated in Appendix B, this transfer would be accomplished over a period of several years.

Although the repository co-located with this MRS/IS facility would come on-line in 2008 in the Delayed Disposal scenario, the storage facility would still be required to receive wastes until after the second and third repositories open in 2012 and 2015, respectively. Assuming the first repository would be co-located with this MRS/IS facility, then the activities of this facility would be shared with the repository from 2008 to 2016. At that time, all activities would be transferred to the repository.

\subsection{UNIT COSTS AND SCENARIOS FOR TRANSPORTATION}

A significant portion of the cost of operating a waste management system is attributable to the cost of transporting the spent fuel and reprocessing wastes. These costs are also quite sensitive to the scenario for system operation that is selected for analysis. The base unit costs associated with transport of the radioactive materials are presented in this subsection, together with a summary of the transportation links postulated for the MRS/IS facility co-located with a repository for the three principal fuel cycle scenarios. Additional details concerning transportation costs and transport scenarios are given in Appendix $C$.

\subsubsection{Unit Transportation Costs}

Unit transportation costs are presented for four fuel-cycle materials: spent fuel, HLW, RHTRU wastes, and CHTRU wastes. RHTRU wastes are further subdivided into three categories: wastes that are packaged in special cylindrical canisters (including compacted cladding hulls), wastes that are packaged in "standard" 210-1iter (55-gal) drums with surface dose rates less than $5 \mathrm{R} / \mathrm{hr}$, and drummed wastes with surface dose rates greater than $5 \mathrm{R} / \mathrm{hr}$. Transportation costs are calculated for shipments by truck and by rail. 
Transportation links of 500 miles and 2500 miles one way are evaluated. Transportation costs are evaluated only between the boundary fences of the sending and receiving facilities. All handling costs and truck/cask demurrage charges accrued within the MRS/IS facility boundary are attributed to operating costs. Rail car/cask demurrage charges are included in the unit shipping costs.

The reference transportation systems evaluated for this study are listed in Table 3.1. These systems are selected based on availability, licensability, and compatibility with the reference waste packages.

Transportation costs are based on the assumption that private industry will provide the transportation services as a commercial venture, al though the services could be owned and provided by the government. Therefore, total transportation costs are the sum of the shipping charges, special equipment and security costs (where applicable) and shipping container rental fees. The unit transportation costs for truck and rail shipments of the six different cargoes are summarized in Table 3.2 .

Special equipment charges and security costs are currently required for shipments of spent fuel and may be required for shipments of high-level wastes in the future. The costs for HLW shipments shown in Table 3.2 incluce these additional costs.

\subsubsection{Transportation Scenarios}

The transportation requirements are derived from the fuel cycle scenarios developed in Section 3.4 and Appendix B. The primary assumptions used to calculate the number of shipments for each scenario include:

- Al1 waste volumes are transported from the source site(s) to the MRS/IS facility by rail and truck. Fifty percent of the waste volume is assumed to be delivered by rail and 50 percent of the waste volume is assumed to be delivered by truck.

- The transportation containers and their load capacities for each of the waste forms are as listed in Table 3.1 . 
TABLE 3.1. Reference Transportation Systems Selected for this Study

\begin{tabular}{|c|c|c|c|c|}
\hline Material & $\begin{array}{l}\text { Shipping } \\
\text { Mode } \\
\end{array}$ & $\begin{array}{r}\text { Shipping } \\
\text { Container } \\
\end{array}$ & $\begin{array}{c}\text { Waste Packages } \\
\text { Per } \\
\text { Shipment } \\
\end{array}$ & $\begin{array}{l}\text { Leasing } \\
\text { Fee } \\
\text { (\$/Day) } \\
\end{array}$ \\
\hline \multirow[t]{2}{*}{ Spent Fue 1} & Truck & $N A C-1$ & $\begin{array}{l}1 \mathrm{PWR} \text { or } \\
2 \mathrm{BWR}\end{array}$ & $2000(a)$ \\
\hline & Rail & IF -300 & $\begin{array}{l}7 \mathrm{PWR} \text { or } \\
18 \mathrm{BWR}\end{array}$ & 5750 \\
\hline \multirow{2}{*}{$\begin{array}{l}\text { High-Leve1 } \\
\text { Wastes }\end{array}$} & Truck & NAC-1 & 1 canister & 2000 \\
\hline & Rail & IF -300 & 5 canisters & 5750 \\
\hline \multirow[t]{2}{*}{$\begin{array}{l}\text { RHTRU Special } \\
\text { Canister }\end{array}$} & Truck & $H L W-T$ & 11 canisters & 1750 \\
\hline & Rail & $H L W-R$ & 5 canisters & 4375 \\
\hline \multirow{2}{*}{$\begin{array}{l}\text { RHTRU Drums } \\
<5 \mathrm{R} / \mathrm{hr}\end{array}$} & Truck & CNS $14-170$ & 14 drums & 175 \\
\hline & $\operatorname{Rail}^{(b)}$ & CNS $14-170$ & 42 drums & 525 \\
\hline \multirow{2}{*}{$\begin{array}{l}\text { RHTRU Drums } \\
>5 \mathrm{R} / \mathrm{hr}\end{array}$} & Truck & CNS 7-100 & 7 drums & 175 \\
\hline & $\operatorname{Rail}^{(b)}$ & CNS $7-100$ & 21 drums & 525 \\
\hline \multirow[t]{2}{*}{ CHTRU wastes } & Truck & TRU-PACT & $\begin{array}{l}36 \text { drums or } \\
3 \text { boxes }\end{array}$ & 700 \\
\hline & $\operatorname{Rail}(c)$ & TRU-PACT & $\begin{array}{l}72 \text { drums or } \\
6 \text { boxes }\end{array}$ & 1400 \\
\hline
\end{tabular}

(a) Leasing fee for the NAC-1 is calculated from a schedule.

(b) It is assumed that three of these shipping containers can be transported per rail car.

(c) Assumes two truck TRU-PACT versions are transported per rail car. 
TABLE 3.2. Round-Trip Transportation Costs for Truck and Rail Shipments of Spent Fuel and High-Level and Transuranic Wastes(a)

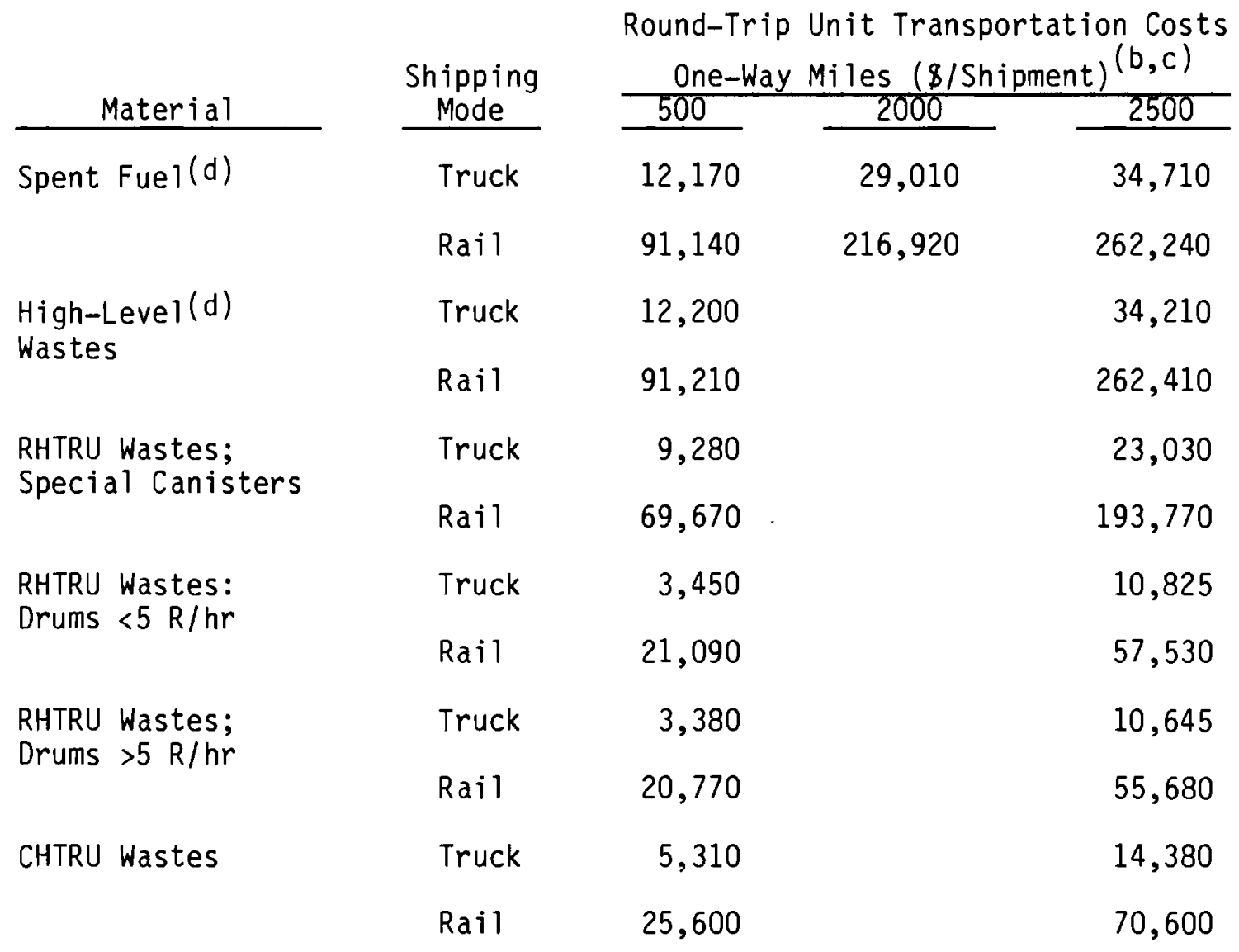

(a) Transportation costs include shipping charges, special equipment and security costs (where applicable) and shipping system rental fees.

(b) Rounded to the nearest 10 dollars.

(c) These costs do not include demurrage fees for truck shipments which are, on average, $\$ 29.30$ for each hour of turnaround time at the terminal facilities. Rail demurrage fees are included in shipping system rental fees.

(d) Costs include charges for special equipment and escort services. 
- The size, weight and capacity of the containers considered for use are shown in Table 3.3.

- The MRS/IS facility goes into service in 1990. Prior to that time, spent fuel requiring storage is held either at the reactor sites or in a temporary storage facility located on a government site.

- Only those incremental offsite transportation costs associated with the MRS/IS facility that are in addition to the transportation costs normally required in the waste management system without an MRS/IS facility are included in the MRS/IS facility life cycle costs.

Other background, bases, and assumptions used for the transportation aspect of this study are given in detail in Appendix $C$.

The annual number of incoming or outgoing shipments for the Reference scenario is listed in Table 3.4. The maximum number of shipments received at the facility occurs in the years 1992 through 1997. During each of those years, 651 truck shipments and 135 rail shipments will require remote handling, and 75 truck shipments and 38 rail shipments of CHTRU will also be processed by the MRS/IS facility.

TABLE 3.3. Reference Canister Sizes and Weights for Offsite Transportation

\begin{tabular}{|c|c|c|c|}
\hline Fuel Cycle Material & Dimensions, $\mathrm{m}$ & $\begin{array}{l}\text { Net } \\
\text { Capacity, } \\
\text { (a) } \\
\left.\text { ( } \mathrm{ft}^{3}\right) \\
\end{array}$ & $\begin{array}{l}\text { Average Weight } \\
\text { Loaded, } \mathrm{kg}(1 \mathrm{~b})\end{array}$ \\
\hline $\begin{array}{l}\text { Spent fuel } \\
\text { PWR assembly } \\
\text { BWR assembly }\end{array}$ & $\begin{array}{l}\text { NA } \\
\text { NA }\end{array}$ & $\begin{array}{l}\text { NA } \\
\text { NA }\end{array}$ & $\begin{array}{l}658(1448) \\
284(625)\end{array}$ \\
\hline $\begin{array}{l}\text { Solidifed high-level } \\
\text { waste canister }\end{array}$ & $0.31 \mathrm{D} \times 3.1$ & $0.17(6.0)$ & $1050(2310)$ \\
\hline $\begin{array}{l}\text { RHTRU wastes } \\
\text { Hulls canister } \\
210 \text { L (55 gal) drum }\end{array}$ & $\begin{array}{l}0.62 D \times 3.1 \\
0.62 D \times 0.92\end{array}$ & $\begin{array}{l}0.75(2.6) \\
0.17(6.0)\end{array}$ & $3500(7700)$ \\
\hline $\begin{array}{l}\text { CHTRU wastes } \\
210 \mathrm{~L}(55-\mathrm{gal}) \text { drum } \\
\text { Metal box }\end{array}$ & $\begin{array}{l}0.62 \mathrm{D} \times 0.92 \\
1.2 \times 1.9 \times 1.9\end{array}$ & $\begin{array}{l}0.19(6.7) \\
3.5(123.6)\end{array}$ & $\begin{aligned} 300 & (660) \\
4000 & (8800)\end{aligned}$ \\
\hline
\end{tabular}


TABLE 3.4. Annual Number of Incoming Shipments at the MRS/IS Facility (Reference scenario)

\begin{tabular}{|c|c|c|c|c|c|c|}
\hline \multirow[b]{2}{*}{ Year } & \multicolumn{2}{|c|}{$\mathrm{HLW}$} & \multicolumn{2}{|c|}{ RHTRU } & \multicolumn{2}{|c|}{ CHTRU } \\
\hline & Rail & Truck & Rail & Truck & Rail & Truck \\
\hline 90 & 24 & 117 & 23 & 99 & 13 & 26 \\
\hline 91 & 47 & 234 & 44 & 201 & 25 & 50 \\
\hline 92 & 70 & 350 & 65 & 301 & 38 & 75 \\
\hline 93 & 70 & 350 & 65 & 301 & 38 & 75 \\
\hline 94 & 70 & 350 & 65 & 301 & 38 & 75 \\
\hline 95 & 70 & 350 & 65 & 301 & 38 & 75 \\
\hline 96 & 70 & 350 & 65 & 301 & 38 & 75 \\
\hline 97 & 70 & 350 & 65 & 301 & 38 & 75 \\
\hline $98-00$ & 0 & 0 & 0 & 0 & 0 & 0 \\
\hline 01 & 10 & 47 & 0 & 0 & 0 & 0 \\
\hline $02-10$ & 0 & 0 & 0 & 0 & 0 & 0 \\
\hline 11 & 47 & 234 & 5 & 1 & 3 & 5 \\
\hline 12 & 24 & 117 & 0 & 0 & 0 & 0 \\
\hline 13 & 42 & 210 & 26 & 120 & 16 & 30 \\
\hline 14 & 70 & 350 & 26 & 120 & 16 & 30 \\
\hline 15 & 0 & 0 & 0 & 0 & 0 & 0 \\
\hline
\end{tabular}

For the Delayed Reprocessing scenario, the MRS/IS facility is used to store spent fuel exclusively, since the repository is opened in 1998. The annual number of incoming shipments for the Delayed Reprocessing scenario is listed in Table 3.5. The maximum annual number of incoming shipments of spent fuel occurs in the years 1996 and 1997 when over 2100 shipments are received each year. The maximum number of shipments away from the MRS/IS facility occurs in the year 2016 when nearly 4000 shipments are made.

The annual number of shipments for the Delayed Disposal scenario is listed in Table 3.6. The maximum number of incoming shipments occurs in the year 2011 when over 3000 shipments of waste are received at the MRS/IS facility. During that year, it is estimated that 2201 truck shipments and 456 rail shipments will arrive which will require remote handing. In addition, 244 truck shipments and 123 rail car shipments of incoming CHTRU wastes will be received at the MRS/IS facility. 
TABLE 3.5. Annual Number of Incoming and Outgoing Shipments at the MRS/IS Facility (Delayed Reprocessing scenario)

\begin{tabular}{|c|c|c|}
\hline \multirow[b]{2}{*}{ Year } & \multicolumn{2}{|c|}{ Spent Fuel } \\
\hline & Rail & Truck \\
\hline 90 & 76 & 583 \\
\hline 91 & 84 & 696 \\
\hline 92 & 107 & 819 \\
\hline 93 & 110 & 832 \\
\hline 94 & 165 & 1268 \\
\hline 95 & 208 & 1560 \\
\hline 96 & 247 & 1888 \\
\hline $\begin{array}{l}97 \\
98\end{array}$ & 246 & 1903 \\
\hline $99-11$ & 0 & 0 \\
\hline 12 & $-105^{(b)}$ & -770 \\
\hline 13 & -84 & -598 \\
\hline 14 & -145 & -1100 \\
\hline 15 & -295 & -2258 \\
\hline 16 & -452 & -3453 \\
\hline 17 & -164 & -1320 \\
\hline 18 & 0 & 0 \\
\hline
\end{tabular}

(a) Reprocessing initiated.

(b) (-) indicates shipment from inventory to an offsite destination. 
TABLE 3.6. Annual Number of Incoming and Outgoing Shipments at the MRS/IS Facility (Delayed Disposal scenario)

\begin{tabular}{|c|c|c|c|c|c|c|}
\hline \multirow[b]{2}{*}{ Year } & \multicolumn{2}{|c|}{ HLW } & \multicolumn{2}{|c|}{ RHTRU } & \multicolumn{2}{|c|}{ CHTRU } \\
\hline & RaiT & Truck & $\overline{\text { Rail }}$ & Truck & $\overline{\mathrm{Rail}}$ & Truck \\
\hline 90 & 24 & 117 & 23 & 99 & 13 & 26 \\
\hline 91 & 47 & 234 & 44 & 201 & 25 & 50 \\
\hline $92-00$ & 70 & 350 & 65 & 301 & 38 & 75 \\
\hline 01 & 94 & 463 & 87 & 398 & 50 & 99 \\
\hline 02 & 117 & 582 & 108 & 503 & 63 & 123 \\
\hline $03-05$ & 140 & 700 & 129 & 603 & 67 & 131 \\
\hline 06 & 187 & 932 & 173 & 800 & 101 & 196 \\
\hline 07 & 234 & 1164 & 215 & 1006 & 125 & 246 \\
\hline $08-10$ & 196 & 980 & 170 & 787 & 98 & 195 \\
\hline 11 & 243 & 1212 & 213 & 989 & 123 & 244 \\
\hline 12 & 136 & 674 & 101 & 476 & 60 & 115 \\
\hline 13 & 76 & 376 & 85 & 399 & 50 & 97 \\
\hline 14 & 126 & 630 & 85 & 399 & 50 & 97 \\
\hline 15 & 17 & 83 & & & & \\
\hline 16 & 26 & 122 & & & & \\
\hline
\end{tabular}




\subsection{MRS/IS/REPOSITORY FACILITY}

The various considerations related to the MRS/IS/Repository facility whose preconceptual design is developed in this report are presented in this section. These considerations include licensing aspects, safety and environmental concerns, functional criteria and facility requirements, site location and description, system descriptions, schedule and cost distributions, and life cycle costs. These considerations are divided into generic considerations and design-specific considerations and are discussed in succeeding subsections.

\subsection{GENERIC CONSIDERATIONS}

Subjects such as licensing, safety, environmental protection, general standards and criteria, and quality assurance are relatively independent of the details of the facility design, and are discussed generically in the following subsections.

\subsubsection{Licensing}

The various bills before Congress all require that the MRS/IS facility be licensed by the Nuclear Regulatory Commission under the appropriate parts of Title 10, Code of Federal Regulations (10 CFR). Principal among these is Part 72, which deals specifically with storage of spent nuclear reactor fuel and other radioactive materials in facilities independent of the reactor. other parts of 10 CFR that are relevant to the design, construction, and operation of an MRS/IS facility include:

10 CFR 20 - Standards for Protection Against Radiation

10 CFR 50 - Appendix B (Quality Assurance) and Appendix E (Emergency Planning)

10 CFR 51 - Licensing and Regulatory Policy and Procedures for Environmental Protection

10 CFR 60 - Disposal of High-Level Radioactive Wastes in Geologic Repositories 
10 CFR 71 - Packaging of Radioactive Materials for Transport

10 CFR 73 - Physical Protection of Plants and Materials

10 CFR 100 - Appendix A, Seismic and Geologic Siting Criteria

10 CFR 170 - Fees for Facilities and Materials Licenses and Other Regulatory Services.

Since the surface handling facilities developed for the MRS/IS facility co-located with a repository will be used by the repository when it is opened, it is expected that additional guidance in the form of Regulatory Guides related to Part 60 will become available in time to be of assistance in the development of the final design of the surface handling facilities.

Depending upon the location of the facility, there may be permits and/or licenses required by state and local agencies. All required licenses and permits will be identified and a schedule established to ensure the availability of necessary information and the timely submission of applications for the necessary licenses/permits.

\subsubsection{Safety}

This program will include measures necessary to assure compliance with applicable safety, fire, and health requirements. Operation of a MRS/IS facility involves the receiving, handling, and storage of radioactive solids in the form of spent fuel, solidified HLW, and packaged TRU wastes. Otherwise, the operations do not involve any significant use of toxic materials. Principal potential safety hazards at the facility are:

- release of radioactive materials

- criticality incidents

- radiation exposure

- fire

- operational hazards - personnel exposure to excessive noise, dust from construction, etc.

- natural phenomena - flooding, tornado, earthquake. 
Systems and operational procedures will be used in the MRS/IS facility to protect facility personnel and the public from nuclear radiation and contamination and to provide industrial safety. Safety will be considered for three circumstances--nomal operating conditions; abnormal operating conditions and conditions resulting from improbable events.

The principal concerns of the facility in regard to safety deal with the handling of the nuclear waste or spent fuel. Considerations for facility safety include layout, design, construction, and, in particular, proper design for nuclear materials handling, such as the use of work zones to limit personnel exposure to radiation, the use of an adequate facility security system, and the use of high safety factors and significant redundance for all systems that receive, handle, and store the nuclear waste.

Containment and filtering is provided to minimize the potential for release of radioactive materials. Criticality incidents and radiation exposure are prevented by careful attention to design concepts and configuration. Comprehensive fire detection and protection equipment are used throughout the entire facility. Potential noise excesses are controlled by equipment isolation, sound-absorbent material, and personnel protection where required. Dust during construction operations is controlled by water sprinkling. Personnel exposure to high temperatures is reduced by ventilation, air-conditioning and worker protection where required. All facilities are designed to withstand the effects of natural phenomena as appropriate for the safety classification of the individual facility.

\subsubsection{Normal Facility Operation}

Containers of wastes are received, handled, stored and eventually retrieved on a routine basis. If additional storage space is being constructed simultaneously to the receipt of material, the two operations will be separate. Protection from radioactivity is provided by the integrity of the waste form, its container and cask, or by the isolation provided for in the waste handling building and in the storage modes. 
During nomal operations, insignificant quantities of airborne radioactivity could be released into the atmosphere. However, exposure of the public shall not be greater than that allowed by 10 CFR 20 and Appendix I to 10 CFR 50. Engineered confinement systems will prevent major release of radioactivity from the waste handling building or from the storage areas.

The waste handling facility will be treated as a "controlled area" in which building ventilation pressure(s) is maintained below ambient atmospheric or adjacent area pressure, thus assuring that possible leakage through the walls will be into, not outward from, any potential source of contamination. Additionally, all exhaust air from the building will be filtered through filter systems that include high-efficiency particulate air (HEPA) filters and then released through a stack. The stack provides for dispersal in the atmosphere of the small amount of radioactivity that may pass through the filters. The stack height is established according to atmospheric conditions at the site; dispersion provides enough dilution that radioactivity reaching ground level is at or below permissible concentrations.

Finally, the occurrence of release of radioactivity from either the waste handling facility or the storage areas depend upon simultaneous leakage from both the waste form and its failed containers, and consequently is expected only rarely.

\subsubsection{Abnormal Operating Conditions}

Anticipated occurrences that could result from equipment failures, operator errors, or unplanned process variations during the operating life of the facilities are considered in terms of possible effect of the failure, how detected, safeguards and recovery procedures. These considerations are incorporated into the design of the facility confinement systems.

\subsubsection{Improbable Events}

Although they have a very low probability of occurring, some upper limit accidents or improbable events justify the incorporation of additional design features to further reduce the probability of their occurrence or to mitigate 
their effects. Improbable events considered include earthquakes, high winds and tornadoes, and floods. Risks due to these natural phenomena are assessed and adequate design provisions made to them, as follows:

- Seismic design of structures, systems and components considers the seismic events of Safety Function Earthquake (SFE), Operating Basis Earthquake (OBE) and Uniform Building Code Earthquake (UBC) and is in accordance with the earthquake level assignment and applicable NRC regulations.

- The Design Basis Wind (DBW) is the same as the Operating Basis Wind (OBW) for the Hanford Site. American National Standard Institute (ANSI) requirements will govern the design.

- There will be no design basis for flood (DBF) because of the elevation of the reference site above the Columbia River.

- An MRS/IS facility need not be protected from tornado missiles but shall be designed to prevent massive collapse of building structures or the dropping of heavy objects on the waste forms as a result of building structure failures.

\subsubsection{Environmental Considerations}

Construction, operation, and decommissioning of an MRS/IS facility by the federal government will require compliance with the National Environmental Policy Act (NEPA). These activities will almost certainly be viewed as major federal actions requiring the preparation of an environmental impact statement (EIS). Two EISS will probably be required, one covering construction and operation of the facility and the other covering decomissioning. The EISs will be prepared in accordance with the regulations of the Council on Environmental Quality (CEQ). In addition, since the facility is to be licensed by the U.S. Nuclear Regulatory Commission (NRC), a safety analysis report (SAR) will be prepared covering operation of the facility. Together, these documents will describe the facility and alternatives to the facility; the environmental impacts of constructing, operating, and decomissioning the facility; the measures taken to assure safety, and the measures taken to monitor safety. 
The proposed MRS/IS facilities are described in Subsection 4.3. The potential environmental impacts associated with these facilities that will require consideration in the EISs are discussed briefly in the following subsections.

\subsubsection{Environmental Impacts During Construction}

During construction of the MRS/IS facility, the environmental impacts will be similar to those of any major construction project, except that construction work force at any time is likely to be less than 200 or 300 people. Therefore, socioeconomic impacts and the impacts from the presence of extra temporary workers or from many people concentrated in a small geographic area will be small. Some of the environmental impacts from construction will be:

- removal of the land from production or other uses

- possible removal of timber from the land

- irreversible use of some construction materials

- irreversible use of fuels and electricity

- occasional minor traffic congestion

- dust from construction activities

- noise from construction activities

- minor socioeconomic impacts.

\subsubsection{Environmental Impacts During Operation}

Radioactive materials, including spent fuel, will be hand led during operation of the MRS/IS facility. Appropriate measures will be taken at all times to avoid criticality and the possibility of any other accident, as well as to minimize occupational or public radiation dose from routine radioactive waste handling activities. Probably the most significant impact from operation of the facility will be the large number of shipments of radioactive material to and from the facility.

The impacts from operation will include:

- routine occupational radiation doses to workers at the facility

- substantial freight traffic to and from the facility hauling radioactive shipments 
- routine public radiation doses due to transportation activities

- potential (small) for accidental offsite releases of radioactivity.

\subsubsection{Environmental Impacts During Decommissioning}

Only the storage areas will need to be decommissioned when the MRS/IS facility ceases operation because the waste handling facility will become part of the repository. Before decommissioning of the storage areas begins, all packaged radioactive wastes will be placed in the repository, leaving only incidental amounts of radioactivity to be removed. Significant quantities of construction materials (e.g., iron) could be reclaimed. The decommissioning work force will be small, so socioeconomic impacts will be small. Some of the impacts from decommissioning will be:

- routine occupational radiation doses from decommissioning activities

- routine public radiation doses from the transportation of radioactive wastes to low-level waste burial grounds

- some noise

- little socioeconomic impact

- traffic to and from land fills.

Because the storage facilities are expected to be essentially uncontaminated, or readily decontaminated at the time of decommissioning, only the last of the listed impacts is expected to be significant.

\subsubsection{General Standards and Criteria}

The design and construction of the MRS/IS facilities are governed by a vast variety of codes and standards. These are summarized briefly in this subsection with a comprehensive listing given in Appendix $D$.

The pertinent codes and standards are listed by title, starting with federal codes.

U.S. Government Codes, Standards, and Guides

- National Environmental Policy Act (NEPA)

- Occupational Safety and Health Administration (OSHA) 
- Code of Federal Regulations, including NRC and DOT requirements and guides

- U.S. Department of Energy Manual Chapters

State of Washington Codes, Standards, and Guides

- Washington Administrative Code, including construction standards and safety standards for handling explosives

- Washington Highway Manual

- Washington Grid System

Industrial and Professional Society Publications

- American Conference of Governmental Industrial Hygienists

- American Concrete Institute

- American National Standards Institute

- American Nuc lear Society

- American Society of Civil Engineers

- American Society of Heating Refrigeration and Air Conditioning Engineers

- American Society of Mechanical Engineers

- American Society for Testing and Materials

- American Water Works Association

- Factory Mutual Resource Corporation Manual

- Government-Industry Data Exchange program

- Institute of Electrical and Electronic Engineers

- Insulated Power Cable Engineers Association

- National Fire Code

- National Fire Protection Association

- Underwriter's Laboratories, Inc.

- Uniform Building Code 


\subsubsection{Quality Assurance}

A quality assurance (QA) program based on the criteria of 10 CFR 50 , Appendix $B$, will be established, implemented, and applied to the structures, systems and components of the MRS/IS facility that are important to safety. The QA program will extend throughout design, development, manufacturing, construction and operation. Primary focus will be on items essential to the integrity of conf inement, to radiological safety, and to prevent criticality events. However, it will also encompass other items and activities at varying levels of assurance.

The QA program shall include:

- designation of organizational responsibilities

- preparation of QA plan, procedures, and instructions including quality levels

- program for training personnel

- implementation and documentation

- documented audit program.

The QA program shall cover the following activities:

- design and development

- procurement

- manufacturing, fabrication, and assembly

- construction and installation

- operation, maintenance, and modification.

\subsubsection{Development of QA Program}

A QA program to ensure the MRS/IS facility does not adversely affect the health and safety of the public will be developed in steps of increasing specificity. An overall QA program document, including general QA procedures and instructions for siting, design, construction, testing, and operation of structures, systems, and components of the facility, will be prepared. The overall program will outline the hierarchy of responsibilities and organizational interfaces, and the procedures for internal controls and auditing. 
Major participating organizations will prepare and submit for review and approval separate detailed $Q A$ plans that meet the requirements set forth by the overall program document. Upon approval, these separate QA plans become part of the overall program. Detailed QA plans will also be required of all lower-tier contractors; these will also be subject to approval and will form part of the overall program upon their approval.

\subsubsection{QA Classifications}

Structures, systems, and components of the MRS/IS facility are to be classified into three levels as related to their importance to nuclear safety.

- Quality Assurance Level I - Level I structures, systems, and components, or portions thereof, will be subjected to the requirements of a quality assurance program established in accordance with guidelines provided in 10 CFR 50, Appendix B. Structures, systems, and components will be considered important to nuclear safety and designated Level I if they are necessary to ensure

- maintenance of the confinement system for the Level I building

- prevention or mitigation of the consequences of accidents which would result in potential offsite exposures as large as 10 percent of 10 CFR 100 limits

- prevention of offsite doses arising from the failure of a system or component containing radioactive material that would result in doses at the site boundary $>500 \mathrm{mR}$ to the whole body or its equivalent to any part of the body.

- Quality Assurance Level II - Structures, systems and components, or portions thereof, that are not Level I but are either essential to normal operation of the MRS/IS facility, essential to preventing a non-nuclear hazard to repository operating personnel, or are required for physical protection against radiological sabotage, will be classified as Level II. Level II structures, systems, and components are not essential for the nuclear safety of the MRS/IS 
facility and their failure could not result in an accident or accident consequences that would release hazardous materials to the offsite environs consisting of:

- radioactivity that would result in doses or concentrations of radioactive material in excess of the limits of 10 CFR 20 , or

- hazardous or toxic materials in concentrations that would cause undue risk to the health and safety of the general public.

- Quality Assurance Level III - Structures, systems, and components, or portions thereof, that are not Level I or Level II and the failure of which could not result in any release of radioactive, hazardous, or toxic materials to the environs, will be classified as Level III.

A component may be classified at a lower level than its parent system, provided that the consequences of its failure satisfy the criteria for the lower classification. No component will be classified at a higher level than its parent system. If no specific level is established for a component, it will be considered to be at the classification level of its parent system. This classification will consider safety analyses, programmatic loss potential, and industrial experience.

\subsubsection{Functional Criteria and System Requirements}

The MRS/IS system is intended to receive, store, and ship out spent reactor fuel, solidified $H L W$, and packaged TRU wastes during the time period before availability of a geologic repository and for a reasonable period of time thereafter. The general functional capabilities required of the MRS/IS facility are discussed in Subsection 4.1.6.1.

To be acceptable into the facility, the radioactive materials and the handling and storage system must satisfy a number of specifications. These charcteristics are discussed in Subsection 4.1.6.2.

\subsubsection{Functional Criteria}

The MRS/IS facility which is co-located with a repository will have the capability to receive, store and ship the volumes of spent fuel, solidified $H L W$, and packaged TRU wastes, as described in Appendix B, for the Reference scenario, the Delayed Reprocessing scenario, and the Delayed Disposal 
scenario. The radioactive materials are assumed to be delivered to the MRS/IS site by both rail and highway transport, with the volume of materials evenly distributed between the two transport modes.

The facility will have the capability to unload the materials, inspect as appropriate, repackage when necessary, transfer to the storage locations, retrieve from the storage locations, and ship to another location (reprocessing plant, geologic repository). Process flow diagrams for spent fuel, HLW, RHTRU and CHTRU materials are shown in Figures $4.1,4.2,4.3$ and 4.4 , respectively.

Shielding at the facility will be sufficient to permit handling, inspection and storage of spent reactor fuel that has cooled at least 10 years, or solidified HLW and TRU wastes whose source fuel assemblies were discharged from reactors at least 10 years prior to receipt at the facility, while maintaining occupational radiation exposure within allowable limits.

The storage facilities at the facility will have the capability to transfer sufficient heat from the stored material to the environment to prevent overheating and possible damage to the stored material. The transfer of heat will be accomplished using passive techniques to avoid the need for active operating systems in the storage areas.

The ability to periodically sample the environment within the storage containers and the environment surrounding the storage containers will be provided to assure detection of any unexpected dispersion of the radioactive materials while in storage.

Accountability for all waste packages received by the facility will be maintained until the material is removed from the facility.

The facility will be designed to preclude accidental criticality.

The facility will be constructed in such as way as to facilitate its physical protection and to facilitate safeguarding the stored material.

The facility will have the capability to process and package for disposal radioactive wastes resulting from facility operation.

The facility will have the capability to provide surge storage for 20 waste packages. 


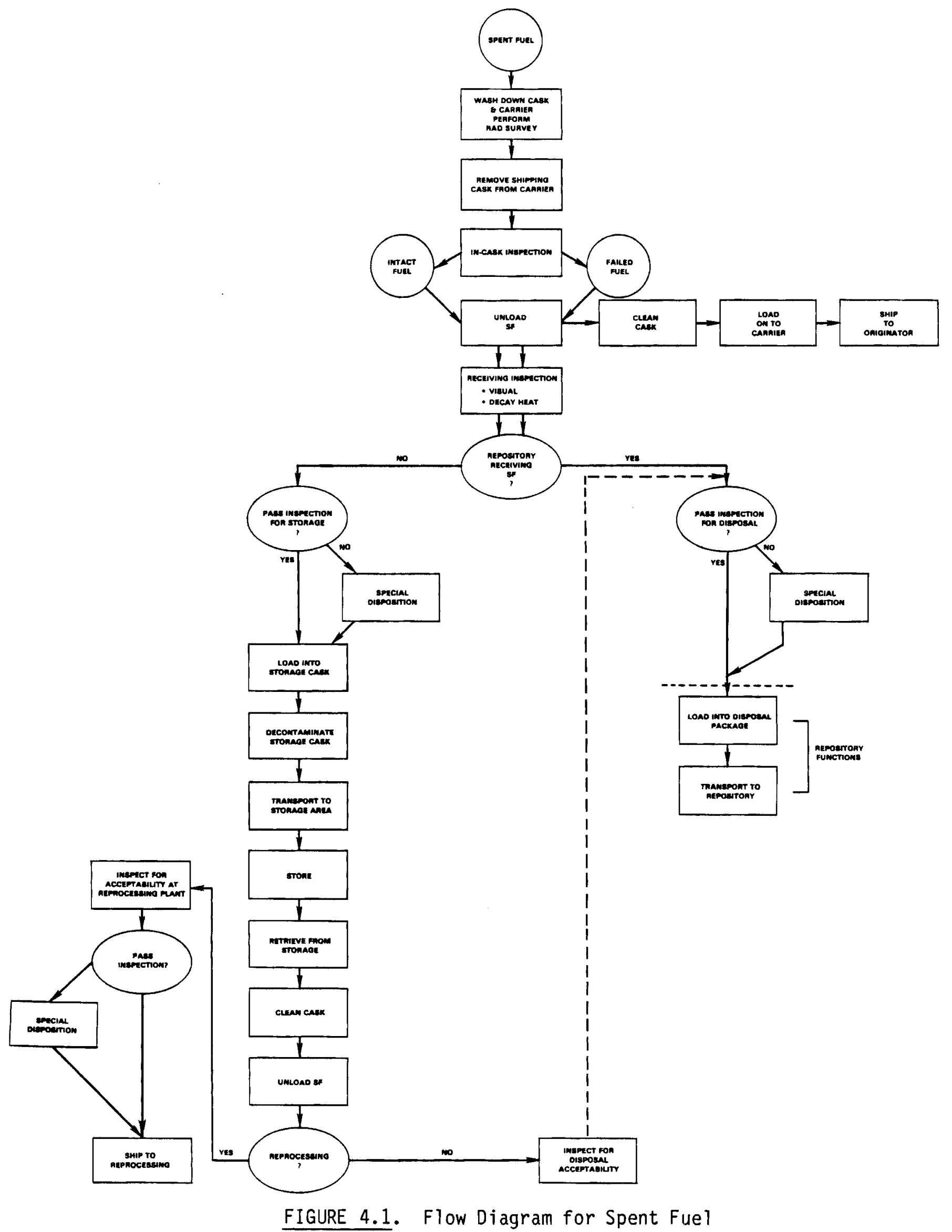

4.13 


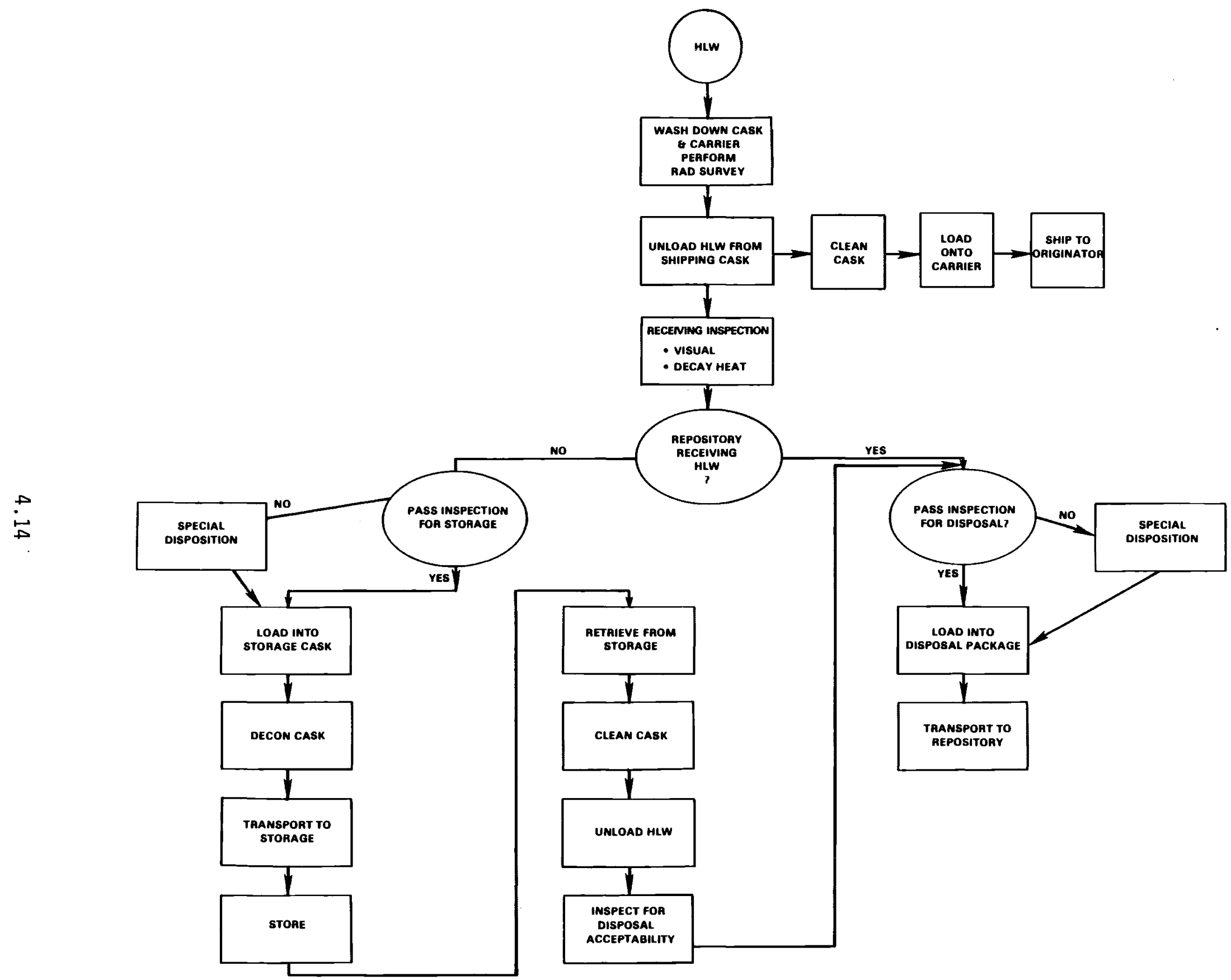

FIGURE 4.2. Flow Diagram for High-Level Waste 


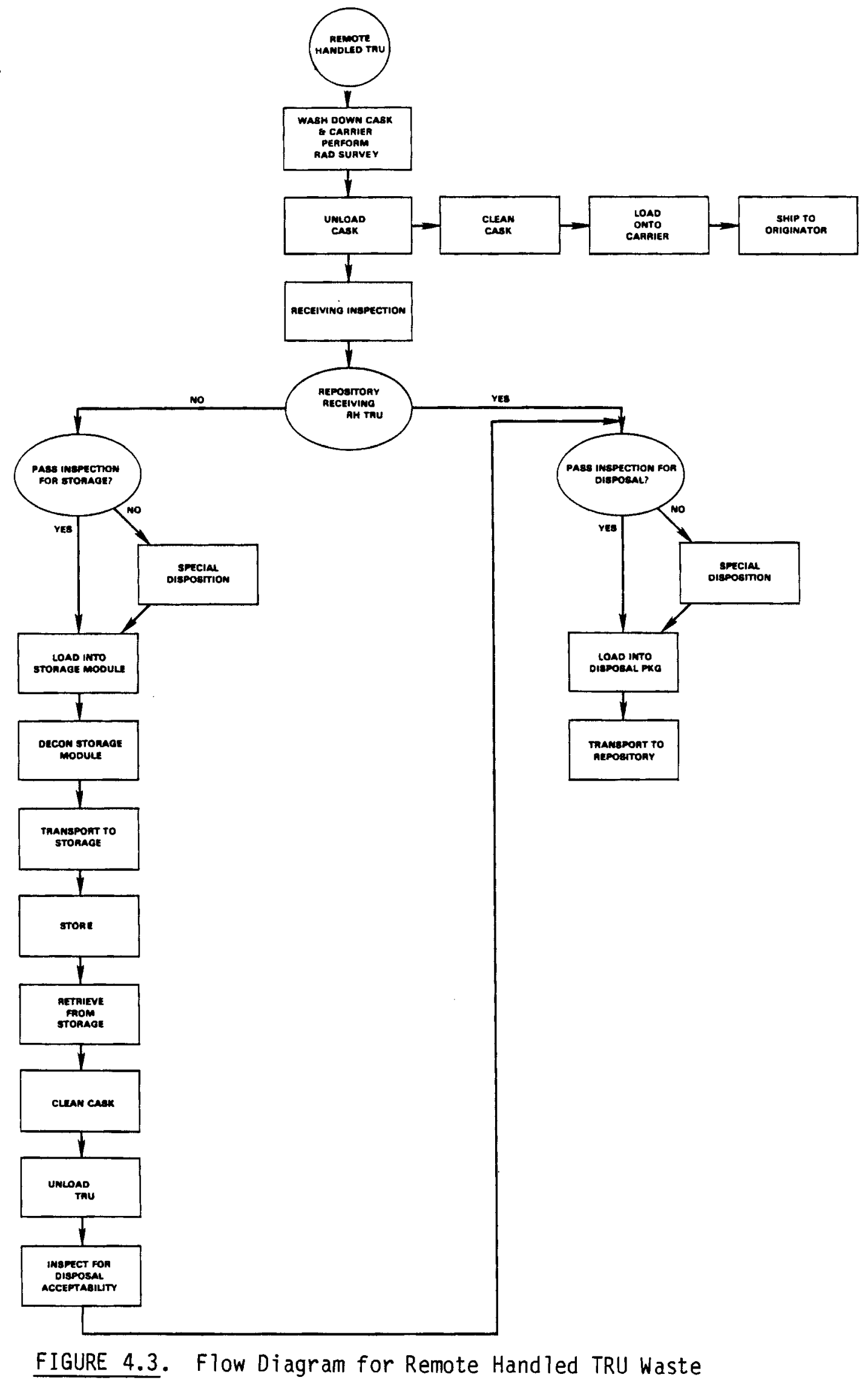




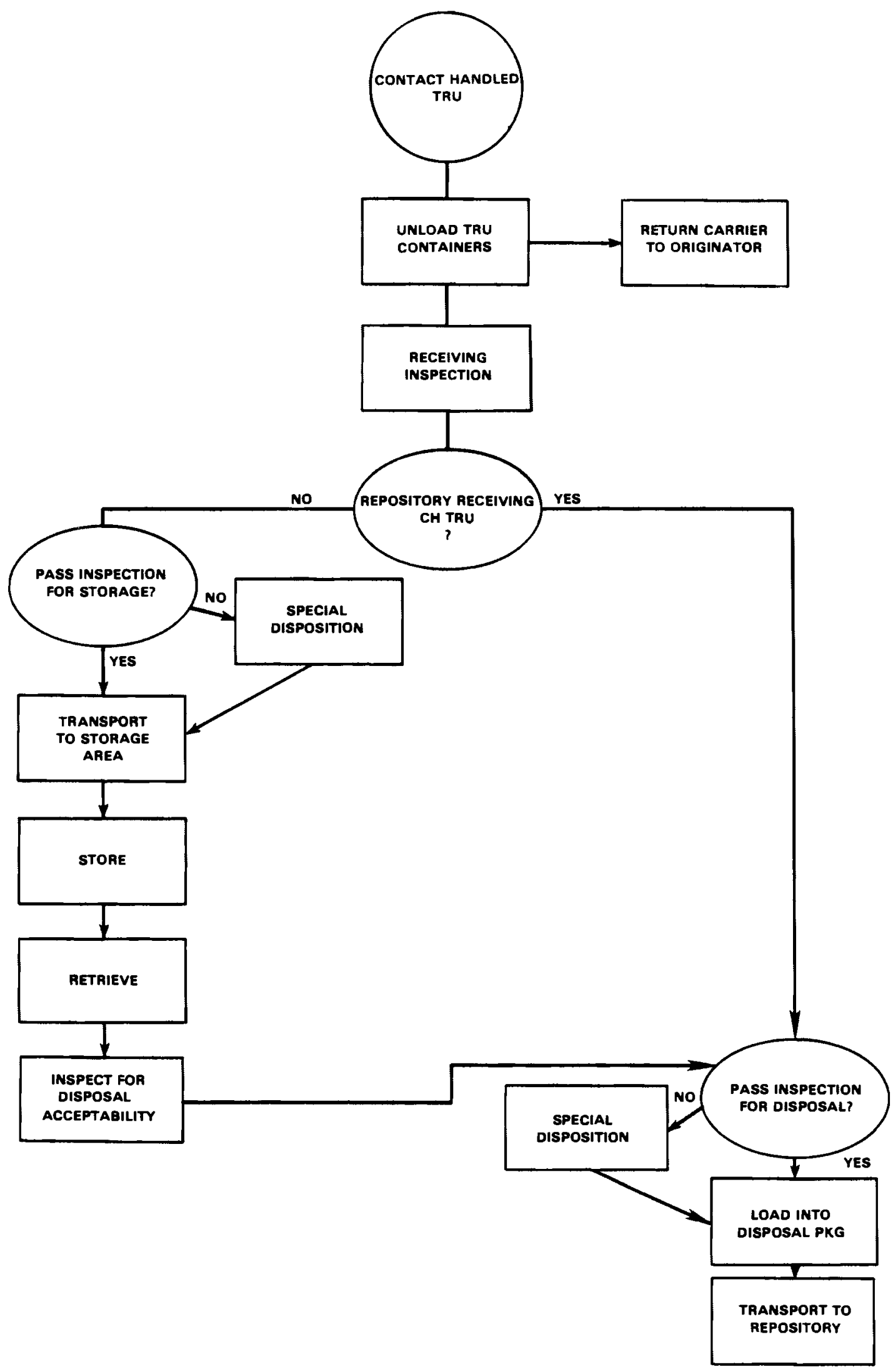

FIGURE 4.4. Flow Diagram for Contact-Handled TRU Waste 


\subsubsection{System Requirements}

Requirements and characteristics of the radioactive materials that are acceptable for storage in the MRS/IS facility and the processing capabilities required at the facility are discussed in this subsection.

Heat Emission. The reference heat emission rates from spent fuel and solidified HLW are given in Table 4.1. It is anticipated most of the materials received by the facility will have lower heat emission rates than the reference case.

Radiation Emission. The gamma surface dose rates and neutron emission rates emanating from unshielded containers of reference waste material are given in Table 4.2 .

Physical Characteristics. The dimensions and weights of waste packages anticipated to be processed at the MRS/IS facility are listed in Table 4.3.

Receiving Capability. The facility has the ability to receive and process or place in surge storage 1 rail car shipment and/or 5 truck shipments per day. Each rail shipment of spent fuel is assumed to consist of 7 PWR or 18 BWR assemblies. Each truck shipment is assumed to consist of 1 PWR or 2 BWR assemblies. HLW canisters are also received in cask shipments, 1 canister per truck cask, 5 canisters per rail cask. The TRU wastes in 55-gallon drums are received in the TRU-PACT container (72 drums, 6 boxes/rail; 36 drums, 3 boxes/truck).

TABLE 4.1. Reference Heat Emission Rates

\begin{tabular}{|c|c|}
\hline Package & $\begin{array}{l}\text { Watts, } 10 \text { Years } \\
\text { After Discharge } \\
\end{array}$ \\
\hline PWR element $(\mathrm{a})$ & 550 \\
\hline BWR element ${ }^{(b)}$ & 175 \\
\hline HLW canister (c) & 2300 \\
\hline
\end{tabular}

(a) $462 \mathrm{~kg}$ initial U, 35,000 MWD/MTU exposure.

(b) $186 \mathrm{~kg}$ initial U, 25,000 MWD/MTU exposure.

(c) 2.14 MT initial U processed, 60 percent PWR, 40 percent BWR. 
TABLE 4.2. Reference Gamma Dose Rate and Neutron Emission Rates

\begin{tabular}{|c|c|c|}
\hline Package & $\begin{array}{l}\text { Gamma Surface } \\
\text { Dose Rate, R/hr }\end{array}$ & $\begin{array}{l}\text { Neutron Emission } \\
\text { Rate, } \mathrm{n} / \mathrm{sec} \\
\end{array}$ \\
\hline HLW canister ${ }^{(a)}$ & $1 \times 10^{5}$ & $5 \times 10^{8}$ \\
\hline Hulls canister ${ }^{(b)}$ & $1 \times 10^{3}$ & $5 \times 10^{6}$ \\
\hline Hardware canister $(c)$ & $3 \times 10^{4}$ & -- \\
\hline
\end{tabular}

(a) 2.14 MT initial $U$ processed, 60 percent PWR, 40 percent BWR, 10 years from discharge.

(b) Hulls from processing 4.4 MT initial U, 0.5 percent loss, 5 years from discharge.

(c) Hardware from processing 10.7 MT initial U. Dose rate is proportional to calculated cobalt in hardware five years after discharge.

TABLE 4.3. Reference Physical Characteristics of Wastes

\begin{tabular}{|c|c|c|}
\hline Waste Type & $\begin{array}{c}\text { Nominal } \\
\text { Dimensions, } \mathrm{ft}\end{array}$ & $\begin{array}{l}\text { Nominal } \\
\text { Weight, } 1 \mathrm{~b}\end{array}$ \\
\hline PWR fuel & $16.7 \times 0.71 \times 0.71$ & 1,500 \\
\hline BWR fuel & $15 \times 0.46 \times 0.46$ & 600 \\
\hline $\begin{array}{l}\text { HLW glass } \\
\text { canister }\end{array}$ & $10.0 . \times 10$ & 1,700 \\
\hline $\begin{array}{l}\text { Compacted hull } \\
\text { canister }\end{array}$ & $20.0 . \times 10$ & 1,700 \\
\hline $\begin{array}{l}\text { Fuel hardware } \\
\text { canister }\end{array}$ & $20.0 . \times 10$ & 1,700 \\
\hline $\begin{array}{l}\text { Remote-handled } \\
\text { TRU canister }\end{array}$ & $20.0 . \times 10$ & $1,700(a)$ \\
\hline $\begin{array}{l}\text { Remote-handled } \\
\text { TRU container }\end{array}$ & 55-gal drum & $900(a)$ \\
\hline $\begin{array}{l}\text { Cont act-handled } \\
\text { TRU container }\end{array}$ & 55-gal drum & $900(a)$ \\
\hline $\begin{array}{l}\text { Contact-handled } \\
\text { TRU container }\end{array}$ & $4 \times 6 \times 6$ box & $14,000(a)$ \\
\hline
\end{tabular}

(a) TRU wastes mixed with concrete for stabilization within the container. 
Processing Capability. The facility has the ability to repackage for storage as required and to store spent fuel assemblies at a maximum rate of 1500 assemblies per year (750 PWR, 750 BWR) or HLW at a maximum rate of 700 canisters per year (equivalent to $\sim 1500$ metric tons of spent fue1), RHTRU at a rate of $\sim 550$ canisters and $\sim 70055-$ gallon drums per year, and CHTRU at a rate of $\sim 3300$ 55-gallon drums and twenty-five 4- $x 4-\times 6$-foot boxes per year. These rates are equivalent to throughputs for the hot cell/transfer/repackaging station of about 6 spent fuel assemblies ( 3 PWR, 3 BWR), 3 HLW canisters, 2 RHTRU canisters and 3 RHTRU drums per day. The facility is assumed to operate on the following schedule:

$$
\begin{aligned}
& \text { Receiving } \quad-300 \text { days/yr, three } 8 \mathrm{hr} \text { shifts/day, } 7 \text { days/wk } \\
& \text { Packaging/transfer }-250 \text { days/yr, three } 8 \mathrm{hr} \text { shifts/day, } 5 \text { days/wk. }
\end{aligned}
$$

\subsection{SITE LOCATION AND DESCRIPTION}

The assumed location for this MRS/IS facility co-located with a geologic repository is within the boundaries of the Hanford Site. Hanford occupies $\sim 570 \mathrm{mi}^{2}\left(1500 \mathrm{~km}^{2}\right)$ in the semiarid region of Southeastern Washington (see Figure 4.5).

\subsubsection{Site Location and Arrangement}

A hypothetical site for the MRS/IS facility is postulated to be located west of the 200 West area within the Hanford Site above the Cold Creek Syncline. The facility site arrangement, shown in Figures 4.6 and 4.7 , is compatible with the constraints of the hypothetical site and should also satisfy the requirement of the follow-on repository and its operation. Approximately 250 acres will be required for the initial facility. To cover the interim storage requirements for the various scenarios, up to 400 total acres may be required. In comparison, about 550 acres are projected to be required at the surface to supply and to support an underground respository that may cover or have a surface projection of up to 2000 acres.

The initial area will be developed by the required site preparation, roads, fences, walkways, and rail systems with due consideration and provisions for the additional areas and facilities that may be required later. 


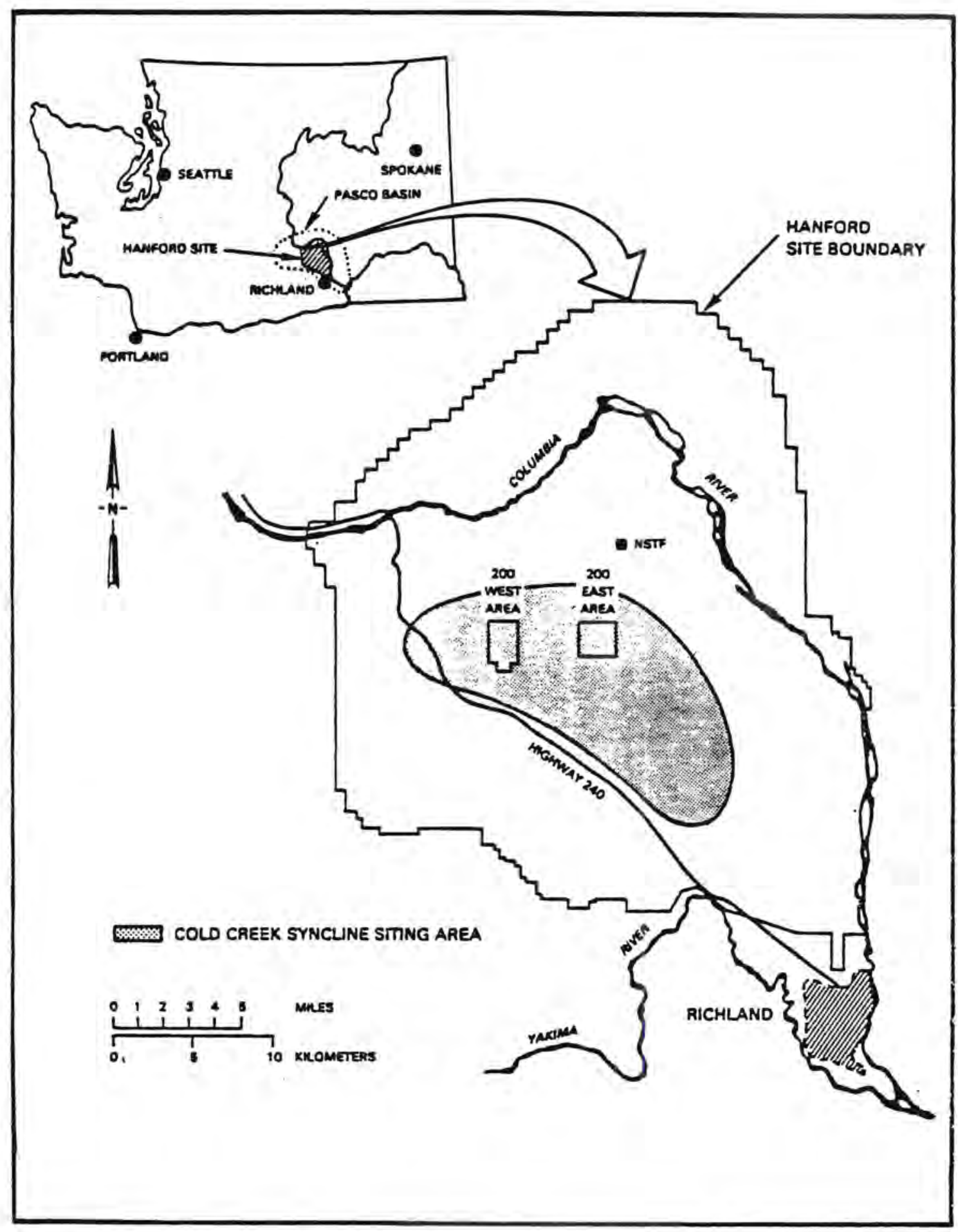

FIGURE 4.5. Location Map - Hanford Site 
FACILITY INDEX

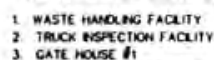
cart house ti

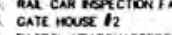

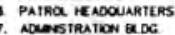

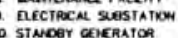

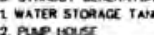
14 wheriouse

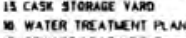

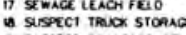

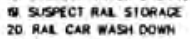

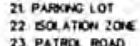

$\stackrel{+}{\sim}$

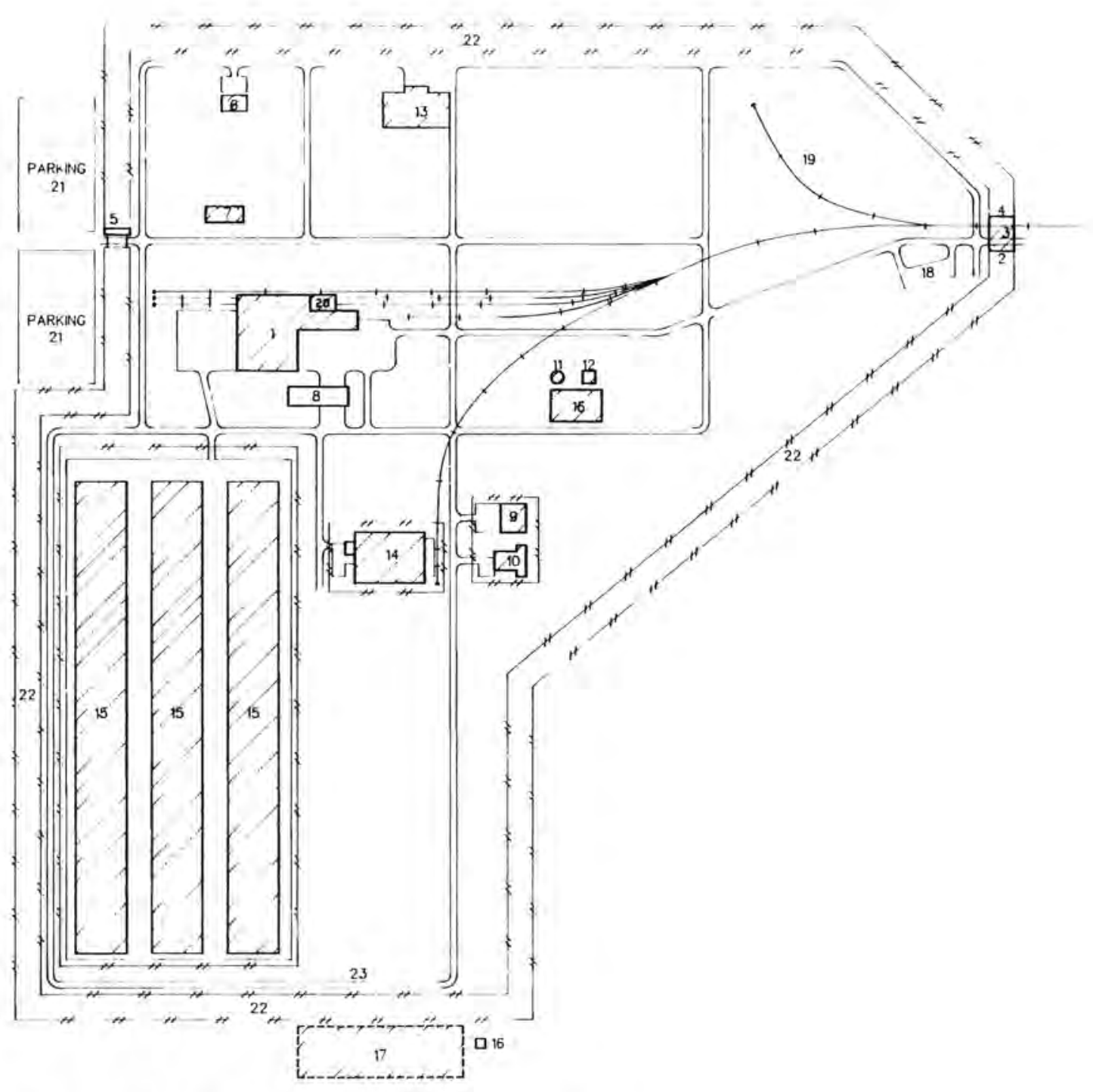

FIGURE 4.6. MRS/IS Facility Site Arrangement 
FACILITY II IDEX

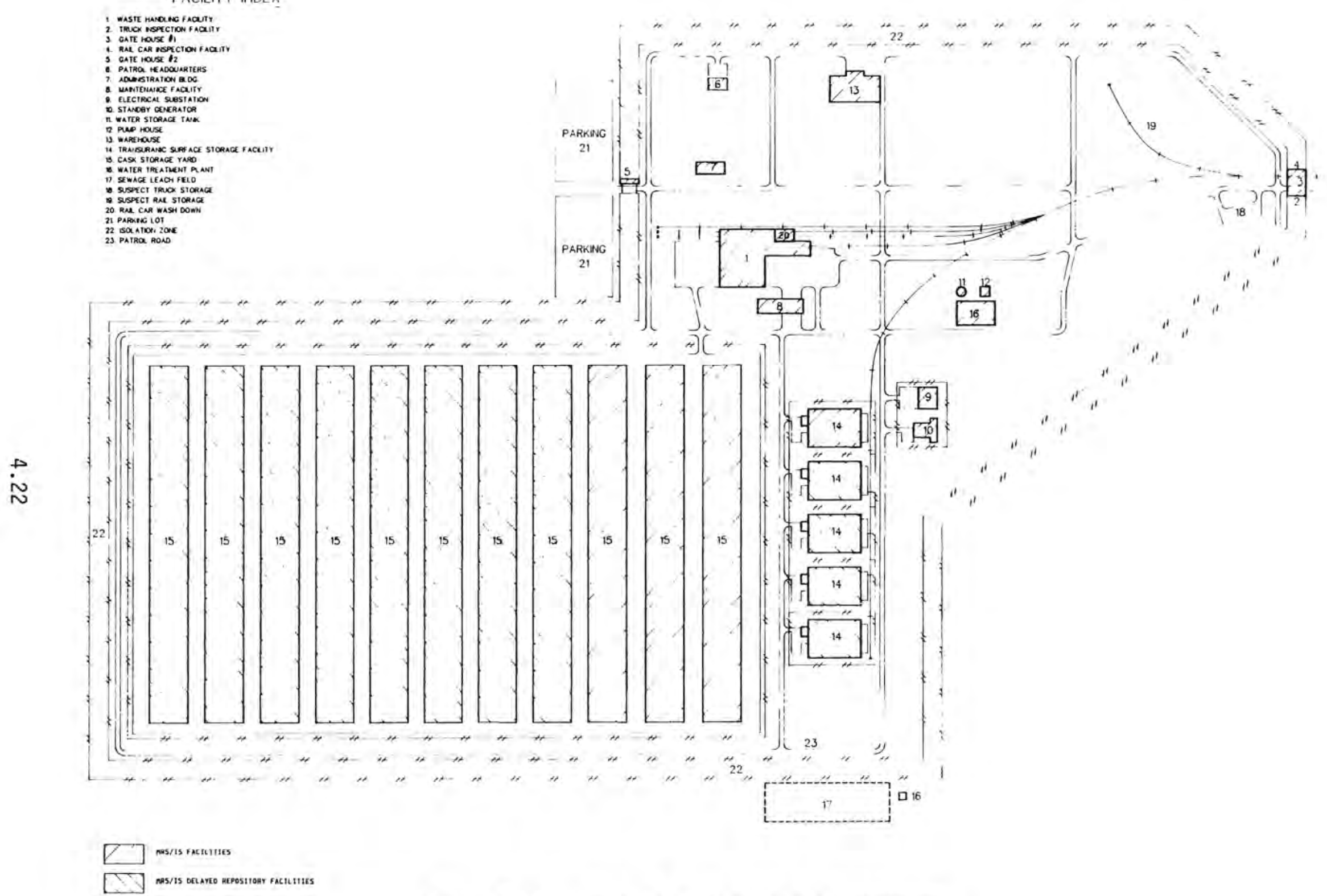

FIGURE 4.7. Expanded MRS/IS Site Arrangement 


\subsubsection{Site Parameters}

Conditions of this hypothetical site are assumed to be in accordance with typical conditions found at Hanford. These assumed conditions, which include climatology, ecology, hydrology, environment, terrain and geologic formations, and flood plain management, are discussed in subsequent subsections.

Real-time wind speed, direction, and stability data are available from the Hanford Meteorological Station, which has been in continuous operation since the middle 1940s.

\subsubsection{Climatology}

The Hanford climate is generally mild and dry with occasional periods of high winds. Summers are generally hot and dry with relatively mild winters, considering the latitude. For the months of January and July, the average maximum temperatures are $36.7^{\circ} \mathrm{F}\left(2.6^{\circ} \mathrm{C}\right)$ and $91.8^{\circ} \mathrm{F}\left(33.2^{\circ} \mathrm{C}\right)$, respective $1 y$, and average minimum temperatures are $22.1^{\circ} \mathrm{F}\left(-5.5^{\circ} \mathrm{C}\right)$ and $61.0^{\circ} \mathrm{F}\left(16.1^{\circ} \mathrm{C}\right)$, respectively. Average annual precipitation is 6.25 inches $(15.9 \mathrm{~cm})$ with 42 percent occuring November through January. Average monthly wind speeds fluctuate from $5 \mathrm{mph}(2.3 \mathrm{~m} / \mathrm{s})$ during winter months to $9 \mathrm{mph}(4.1 \mathrm{~m} / \mathrm{s})$ during summer months, with the prevailing wind direction from the northwest, although the strongest winds are from the southwest.

Tornadoes are infrequent in the region; they tend to be small and cause little damage when they do occur. A single, small tornado has been observed onsite, but no damage was reported. Fourteen tornadoes have been confirmed within 100 miles $(160 \mathrm{~km})$ of the Hanford Site between 1916 and the present. Data have been analyzed to determine the probability of a tornado hitting a particular Hanford facility. During any year, it is estimated that the probability is six chances in a million or less than once in 100,000 years.

The number of thunderstorm days at Hanford gives an estimated annual lightening-strike frequency of 0.022 for a building 30 feet $(9 \mathrm{~m})$ high. This frequency corresponds to about one strike per 45 years.

\subsubsection{Hydrology}

The hydrology of the Hanford Site consists of both surface and subsurface flow systems. The Columbia and Yakima Rivers form the principal surface water 
drainage of the area. On an average, these rivers discharge 100,000 and $10,000 \mathrm{ft}^{3} / \mathrm{sec}\left(2,830\right.$ and $\left.283 \mathrm{~m}^{3} / \mathrm{sec}\right)$, respectively. Two ephemeral streams occur along the extreme western boundary of the Hanford Site, but their water discharges are very low, even during the rainy season. Various ditches and ponds in and near the 200 Areas contain cooling and process waters, which either evaporate or recharge the underlying unconf ined aquifer.

The groundwater flow systems consist of unconfined and numerous confined aquifers. Hydrologic knowledge of aquifer properties is quite extensive for the unconfined system; however, it is less complete for the confined systems, particularly those small systems within the deeper basalts. An extensive field testing program is under way to acquire a solid understanding of all confined aquifers that may be important in designing and siting an underground repository.

Groundwater beneath the Hanford Site occurs in either an unconfined aquifer or in one of several deeper confined aquifers. The unconfined aquifer consists of both galciofluvial sand and gravel deposit and the Ringold silts and gravels. The Yakima River recharges the unconfined aquifer. The unconfined aquifer overlies a series of confined aquifers, including portions of the lower Ringold Formation and interbeds of the Columbia River Basalt Group.

\subsubsection{Ecology}

The Hanford Site is described as a "shrub-steppe" zone characterized by low precipitation and wide daily and annual temperature ranges.

The vegetation consists primarily of eight major kinds of shrub-steppe communities identified by the most conspicuous or abundant plant species:

- sagebrush/bluebunch wheatgrass

- sagebrush/cheatgrass or sagebrush/Sandberg bluegrass

- sagebrush-bitterbrush/cheatgrass

- greasewood/cheatgrass/saltgrass

- winterfat/Sandberg bluegrass

- Thyme buckwheat/Sandberg bluegrass

- cheatgrass-tumble mustard

- willow. 
The sagebrush/bluebunch wheatgrass and sagebrush-bitterbrush/cheatgrass vegetation types cover extensive acreage. Bluebunch is the most important livestock forage. Cheatgrass provides forage for mule deer, especially in the fall and winter.

Scarcity of grass allows the invasion of tumbleweed, especially in burn-over areas. Both cheatgrass and tumbleweed are we11 adapted to invading disturbed habitats. They will become more prevalent on the Hanford Site as soil is disturbed by construction.

\subsubsection{Environment}

The MRS/IS facility site is to be incorporated into an environment already slightly altered from its original state due to 1) livestock grazing and 2) the activities associated with Hanford projects since the early 1940s. Land within a $50-$ mile $(80 \mathrm{~km})$ radius is used primarily for grazing, growing wheat, and irrigated farm crops. The nearest military facility is the U.S. Anmy Yakima Firing Range located $\sim 30$ miles $(48 \mathrm{~km})$ to the northwest. There are no recreational facilities within a 5 -mile radius of the proposed site. The closest public highways are State Highways 12, 240 and 24.

\subsubsection{Terrain and Geology}

The Hanford Site lies on the low-lying, partly dissected, and modified alluvial plain of the Columbia River within the central part of the Pasco Basin. Most of the Hanford site is underlain by generally coarse-grained sediments deposited by several glacial floods. Sediments at or near the ground surface range from coarse boulder and cobble gravel in the extreme northern reaches, to sandy cobble and granular gravels in the central part of the site, to coarse sands in the southern part. The entire site is blanketed by a veneer of wind-blown (eolian) sediments that range from very fine sands and silts to coarse sand.

The MRS/IS facility site is underlain by 1000 feet $(300 \mathrm{~m})$ of sands, silts, and clays laying on a basalt lava accumulation estimated to be 10,000 feet $(3000 \mathrm{~m})$ thick. The soil type which makes up the site consists of Rupert Sand, which is mostly composed of granitic, quartzitic, and basaltic sand. 
The Hanford Site 1 ies in a region characterized by few earthquakes of damaging intensity, with no clear-cut relationships of epicenters to specific surface faulting or specific geologic structures. To date, no intensities greater than four on the Modified Mercalli Scale (MM-IV) with a gravitational ground acceleration of $0.01 \mathrm{~g}$ have occurred in the immediate Hanford Site area, although intensities as high as MM-V or MM-VI have been observed in surrounding areas.

\subsubsection{Floodplain Management}

Because of recurring damages due to flooding, proper floodplain management has become an item of national concern. The proposed facility site is not located in a floodplain as defined by 10 CFR 122. By definition, a floodplain is any low land or relatively flat area adjoining inland or coastal waters, that are flood-prone and subject to a 1 percent or greater chance of flooding in any given year (the 100-year flood). The estimated 100-year maximum Columbia River flood of 444,000 cfs would result in a river elevation of $356 \pm 2$ feet mean sea leve1 (MSL) based on U.S. Corps of Engineers projections.

The probable maximum flood (PMF), as evaluated by the U.S. Corps of Engineers, would result in a Columbia River elevation of $382 \pm 4$ feet with an occurrence rate of once every several thousand years. The hypothetical site for the MRS/IS facility is at an elevation of $\sim 600$ feet MSL; therefore, it is concluded that the site would not be subject to inundation by any flood having a volume equal to or less than the PMF.

\subsection{SYSTEM DESCRIPTIONS}

The MRS/IS facility consists of the major systems or components described in the following subsections. Security, accountability, monitoring, surveillance, and control functions are provided in the appropriate areas within the facility. 


\subsubsection{Waste Handling Facility}

The waste handling facility (WHF), illustrated in Figure 4.8, is to receive, examine, and prepare for storage both remotely-handled and contact-handled waste. It provides space and systems so the process functions can be accomplished effectively and safely as well as providing the necessary support activities and functions. Its requirements are basically independent of the storage concept used (i.e., surface casks or below-grade drywells). However, requirements and/or size or capacity will vary with the various fuel cycle and transportation scenarios. Also if the drywell storage concept is adopted, additional provisions and capabilities will be required to overpack al1 fuel element bundles on a production basis in the WHF. The building is the sealed-confinement type with ventilation systems adequate to prevent exposure of the public to radiation doses in excess of allowable limits.

The core of the WHF (Figures 4.9, 4.10 and 4.11) is designed for the handiing and transfer of waste packages that require remote handling. This is done in a series of hot cells located on an upper level and flanked by operating and service galleries. On the ground floor, beneath this group, the shipping cask unloading area provides a space in which the incoming cask is upended and connected to the shielding sleeve from the primary hot cel1, thus providing a confined route for transfer of fue1, canisters or drums from the cask to the primary hot cell. Below the secondary cell is another transfer corridor for loading the casks to be transferred to interim storage.

The second waste handling area in the facility is for waste packages that can be contact handled. After preliminary inspection and washdown, the drums or containers are removed from the carriers, inspected for damage, radiation and surface contamination, decontaminated or modified if necessary, and placed on pallets as appropriate for transfer to storage.

The building support areas include radwaste treatment facilities, ventilation and filter rooms, mechanical and electrical rooms, service areas, and administrative areas. 


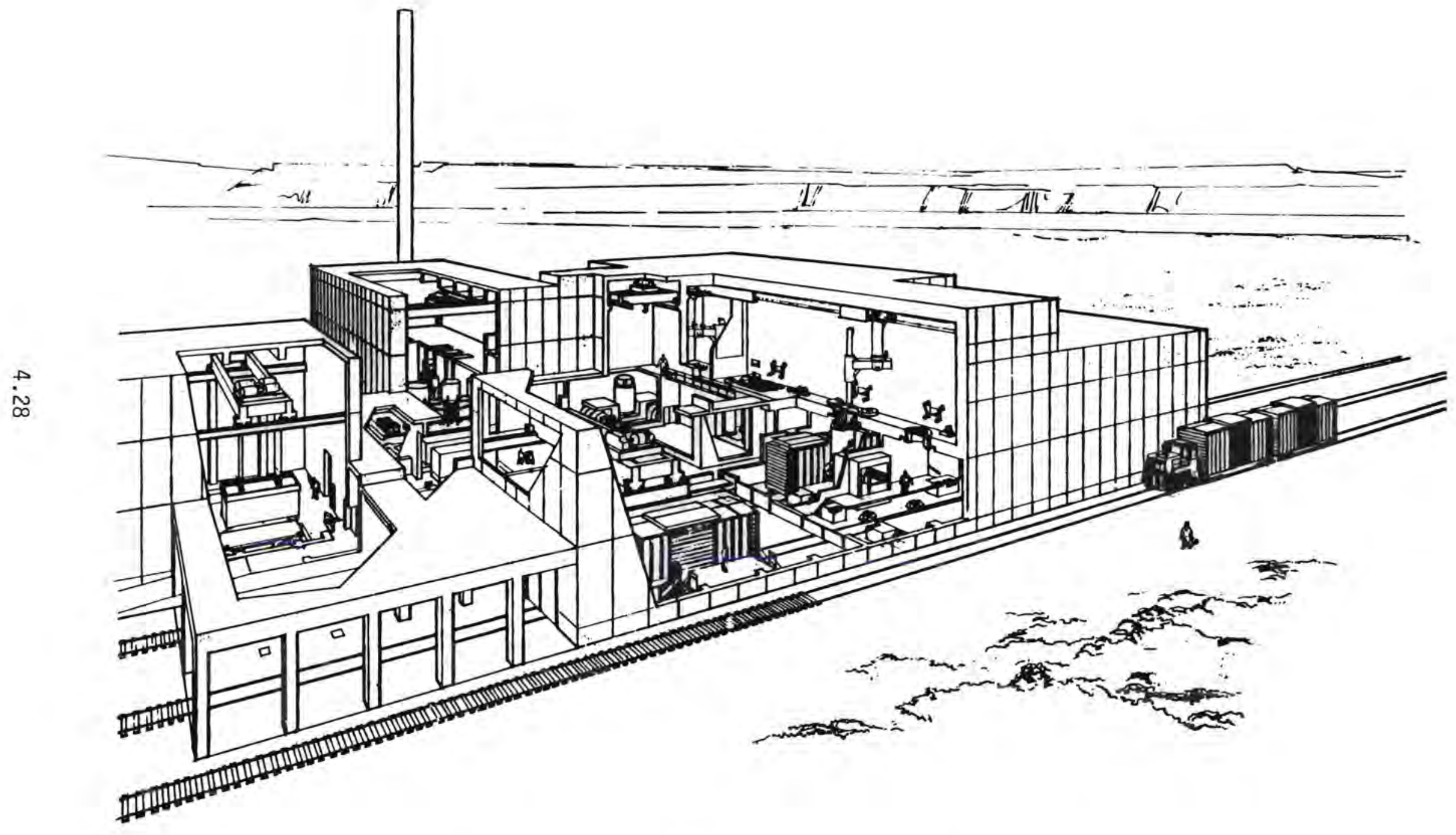

FIGURE 4.8. Waste Handling Facility 


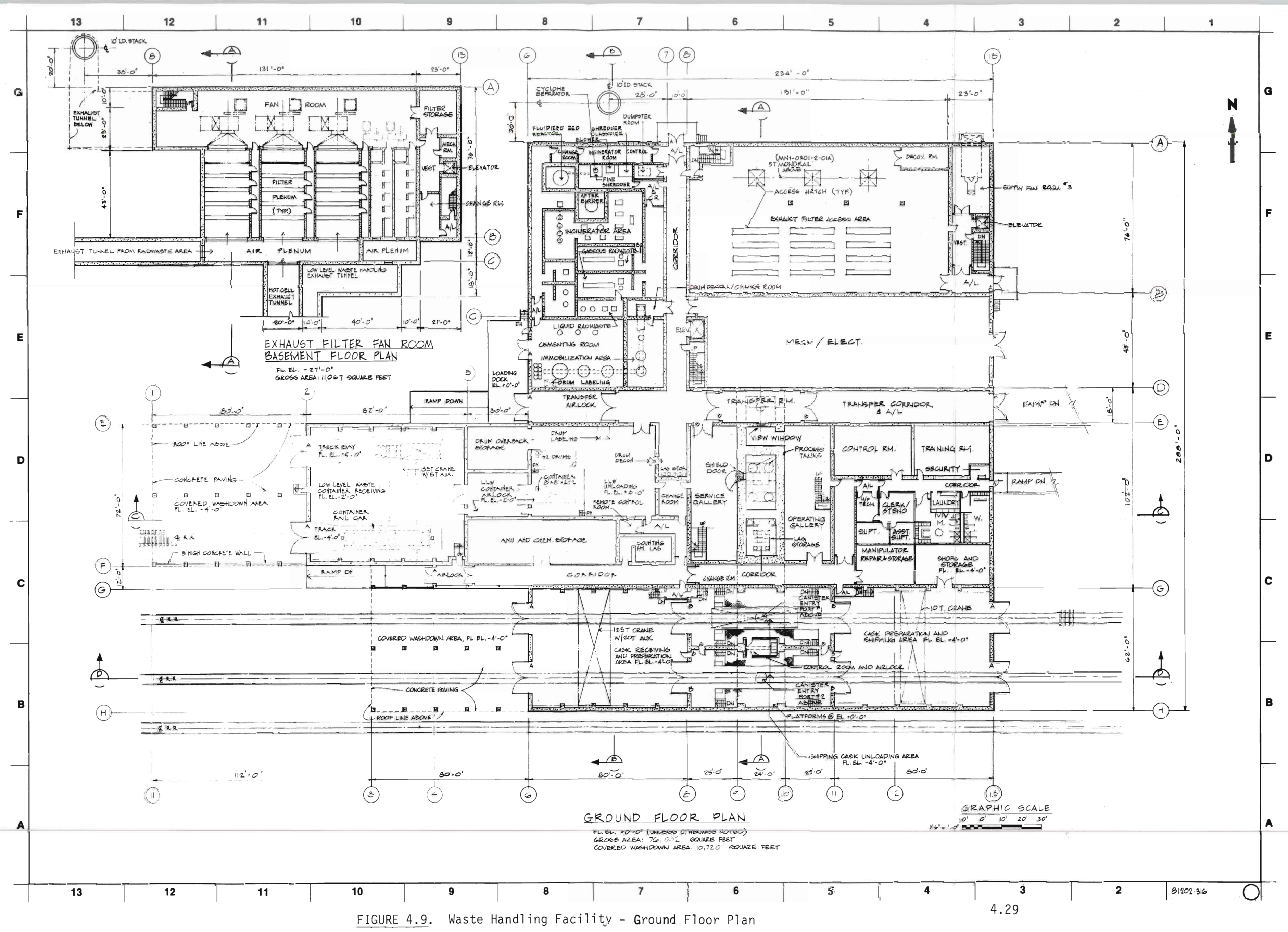




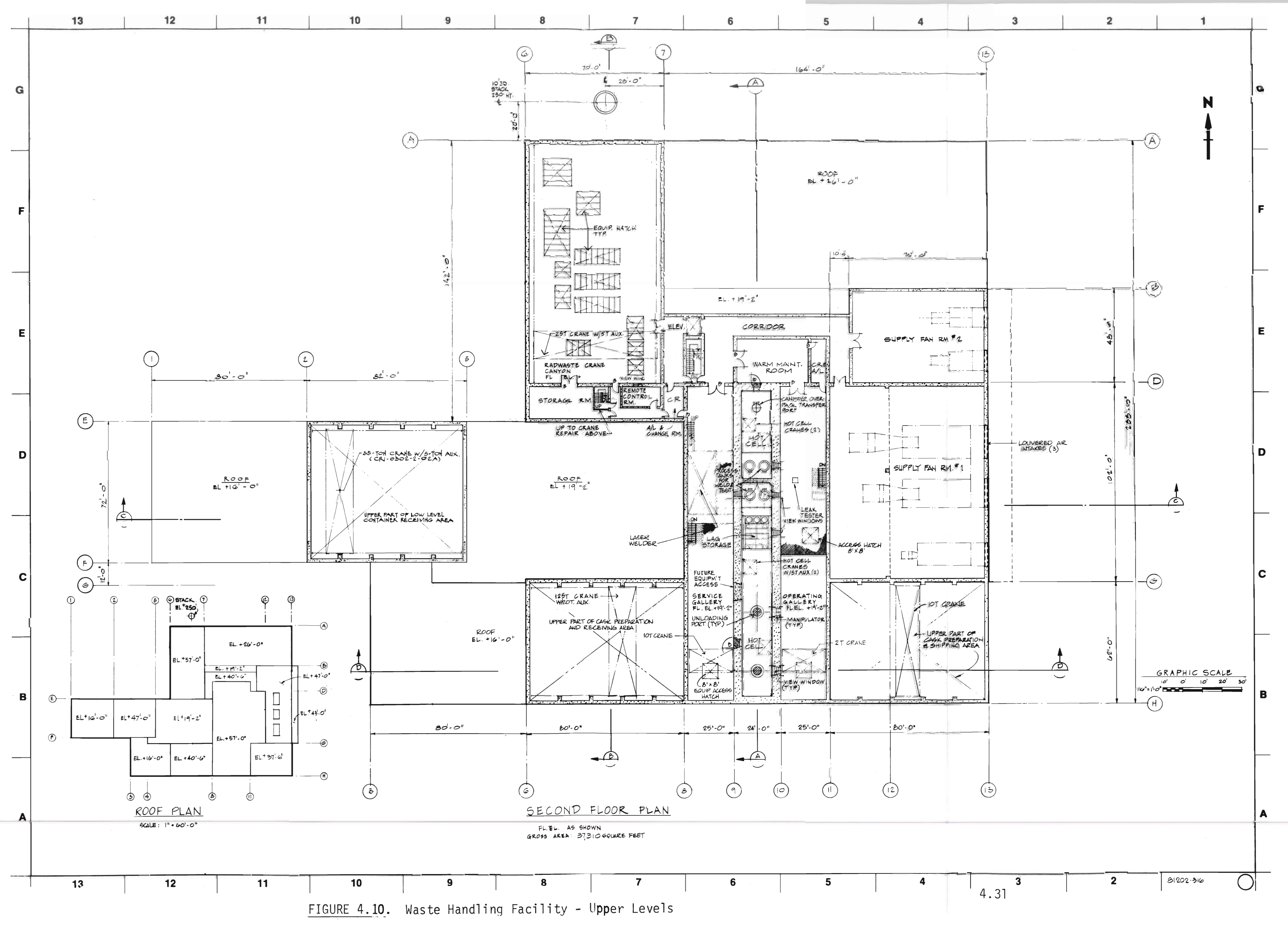




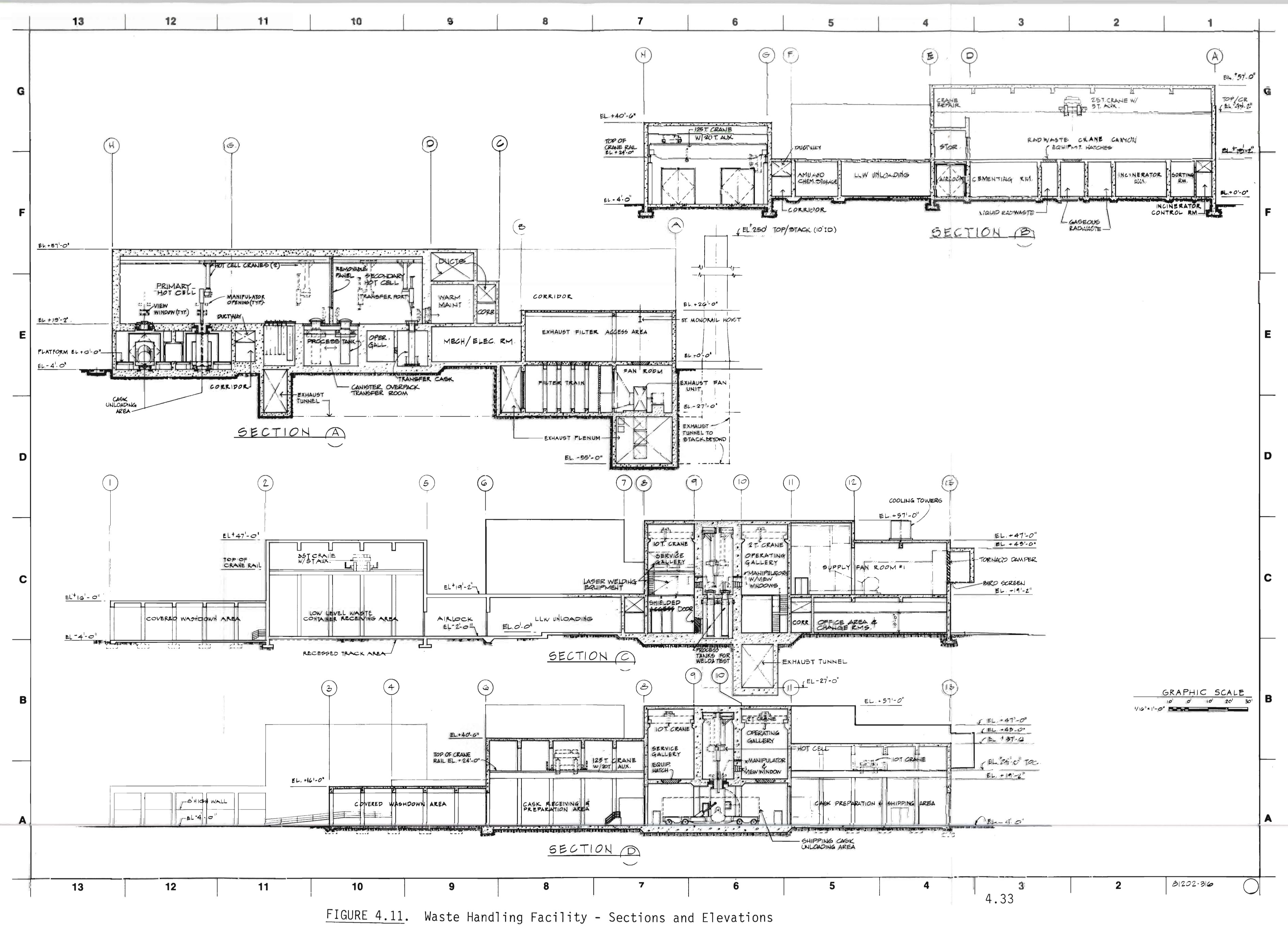


0 
Two separate ventilating systems are furnished in the building: the confinement system for the waste handling areas, and a standard ventilating system for support and administrative areas. The confinement system supplies fresh air to the negative pressure zones of the waste handling areas and exhausts it through a filter system (which includes HEPA filters) and to the stack.

\subsubsection{Cask Receiving and Shipping}

This area of the facility can accommodate at least two rail cars or trucks at any given time. Shipping casks transported either by rail or by truck are inspected, cooled, protected and, as required, they and their contents are transported to the transfer or packaging portion of the facility. This portion of the facility consists of two basic areas: 1) cask carrier preparation and 2) cask and material transfers or unloading. The preparation activities are located in enclosed spaces that also serve as air locks for truck and rail car entry into the transfer area. Basically this portion of the facility has the following process functions (Figure 4.12):

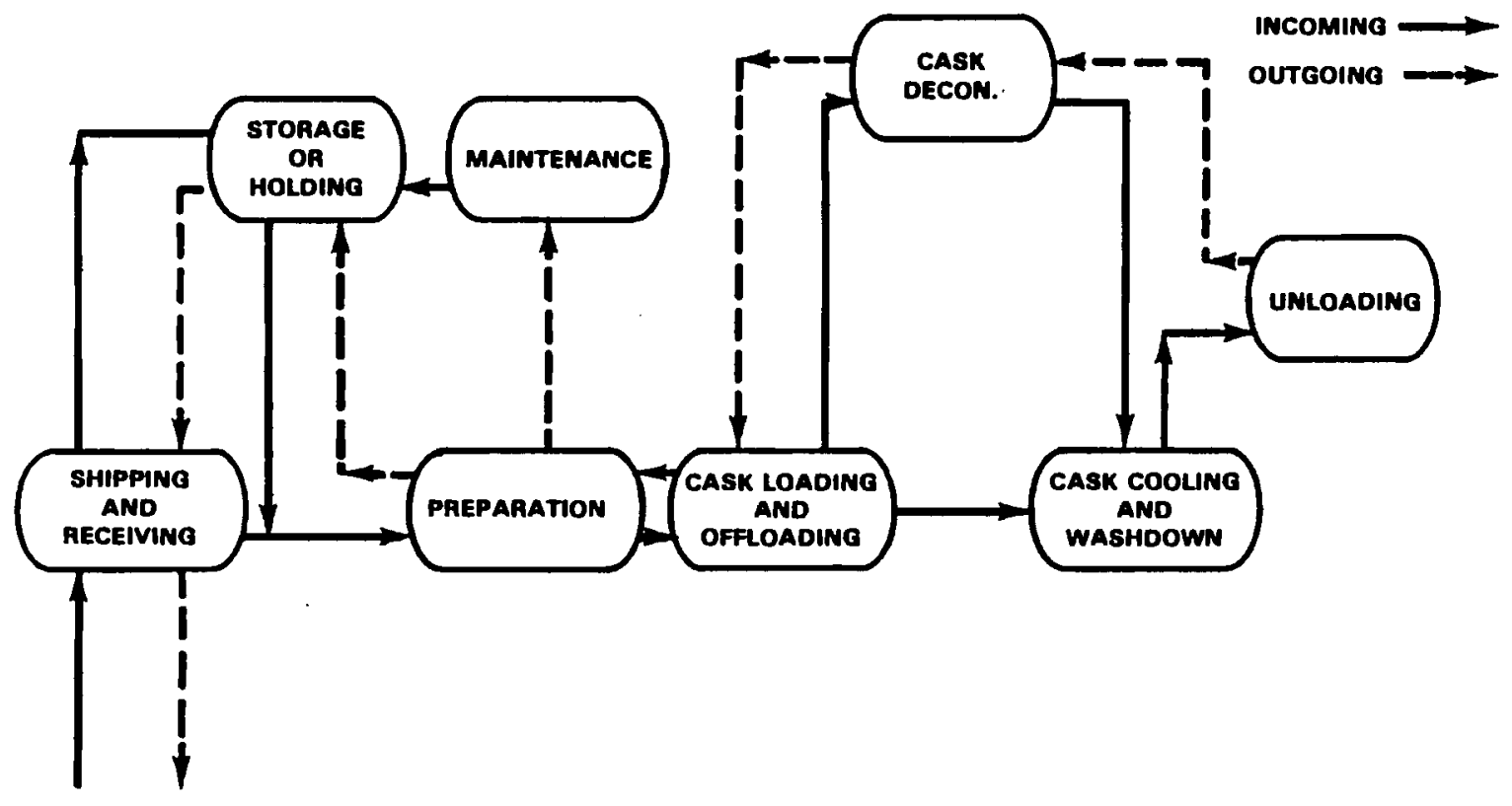

FIGURE 4.12. Cask Receiving and Handling 
1. receiving and shipping - receives loaded casks and returns empty casks

2. cask surge or holding - for the temporary storage of cask(s) and carrier(s)

3. cask maintenance - for minor repair and maintenance of cask(s) and carrier(s)

4. preparation - peripheral equipment is removed from the cask and/or carrier and stored

5. cask loading and offloading - casks can be removed from or loaded on a carrier

6. cooling and washdown - casks can be given exterior washdown or interior venting, flushing and cooling

7. decontamination - casks can be decontaminated as required

8. material unloading - casks can be isolated or mated with the transfer/packaging portion of the facility

\subsubsection{Container Transfer and Packaging}

If the cask is shipped in a horizontal position it will be raised to vertical position on the transporter or set in a vertical position on a special car. Then it will be moved beneath the primary hot cell and mated with a shielded collar lowered from the cell. After removal of the shielding plugs from the hot cell and the cask, each canister or fuel bundle is raised up into the hot cel1. There it is checked as necessary, and it can be stored temporarily in a lag storage location or it can be placed in one of the process tank areas or cells. These areas have the capability of enclosing fuel bundles or canisters in an overpack; inspecting spent fuel or completed waste packages (both helium-leak and ultrasonically tested for structural soundness), and decontaminating if necessary. Clean canisters and packages are transferred from the primary process cells to the secondary (and clean) hot cell. From there the completed waste package is lowered through shielding collars into a storage cask, which can be sealed and made ready for transfer to the storage area. 
The transfer and packaging area of the facility is to be designed to:

- use dry handling of the waste throughout the system

- minimize the number of handling operations in the interest of safety and economy

- receive remotely handled spent fuel bundles, HLW canisters and RHTRU pack ages

- inspect external surfaces of canisters and waste packages for physical damage and contamination

- overpack canisters and fuel (if leaking or damaged or if required for the storage concept) to form acceptable waste packages and inspect the packages following overpacking

- repair canister and waste package closure welds when necessary

- decontaminate canisters and waste packages when necessary

- retain traceability of all waste packages. Remotely operated cranes, manipulators or devices are used to perform the following functions in the transfer and packaging hot cells:

- remove and replace shielding plugs for cell ports

- unlock/lock and remove/replace cask shield plugs

- extract material packages from shipping cask, move them to and through the hot cells, place them in transfer or storage casks; also the reverse of the above sequence

- mechanically interlock the grapple jaws with the payload while the payload is suspended from the crane.

\subsubsection{Contact Material Handling System}

Another portion of the WHF comprises two bays equipped to receive and handle either truck or rail cars, and a system to receive and remove waste containers from the TRU-PACT or similar shipping system; and to process and prepare the drums and boxes for storage. 
After inspection, the entering vehicle is moved to the washdown area for removal of road dirt. Then it goes to the CHTRU waste receiving bay. There a crane offloads the carrier to an air pallet transfer machine which moves the carrier through an air lock into a processing area. In the processing area the drums or boxes are removed from their container by a lift truck and are subsequent ly inspected for surface contamination and radiation level. Drums that show evidence of damage are overpacked into larger drums or containers and are handled separately. Containers having excessive surface contamination are decontaminated by manual methods. Acceptable containers are placed on pallets and made ready for transfer to the transuranic surface storage (TRUSS) facility.

\subsubsection{Transfer and Storage of Contact-Handled Wastes - TRUSS Facility}

The TRUSS facility, shown in Figure 4.13, is an above-ground, warehousetype building designed to optimize CHTRU drum and steel box storage life cycle costs within safety, security, and storage environment requirements. The facility will provide indoor container storage in clean, dry conditions. State-of-the-art handling and storage methods will permit efficient operation with forklifts and a minimum of operating personnel. Containers on pallets can be transported to the TRUSS facility by forklift, truck or rail. The necessary segregation of TRU waste types $c$ an be accomplished within the facility by zoning with interior walls and aisles, or by covering arrays of similar containers with fire retardant protective covers. The internal floor space measures $280 \times 200$ feet $\left(56,000 \mathrm{ft}^{2}\right)$ of which $\sim 35,000 \mathrm{ft}^{2}$ will accommodate a 10-year waste stream volume of 55-gal drums, based on the anticipated waste stream estimates given in Table 4.4. Access aisles will require a total of $-9000 \mathrm{ft}^{2}$ of floor space, leaving $7000 \mathrm{ft}^{2}$ for storing TRU boxes. The facility is sized to accommodate primarily the drummed CHTRU waste generated between the start-up of the MRS/IS facility and start-up of the co-located repository, a period anticipated to be $\sim 10$ years. After repository start-up, it is expected that the drummed TRU waste stream will be diverted directly to the repository, and not require interim storage. At the same time, the inventory of waste stored in the TRUSS facility will be sequentially retrieved and transported to the repository. 


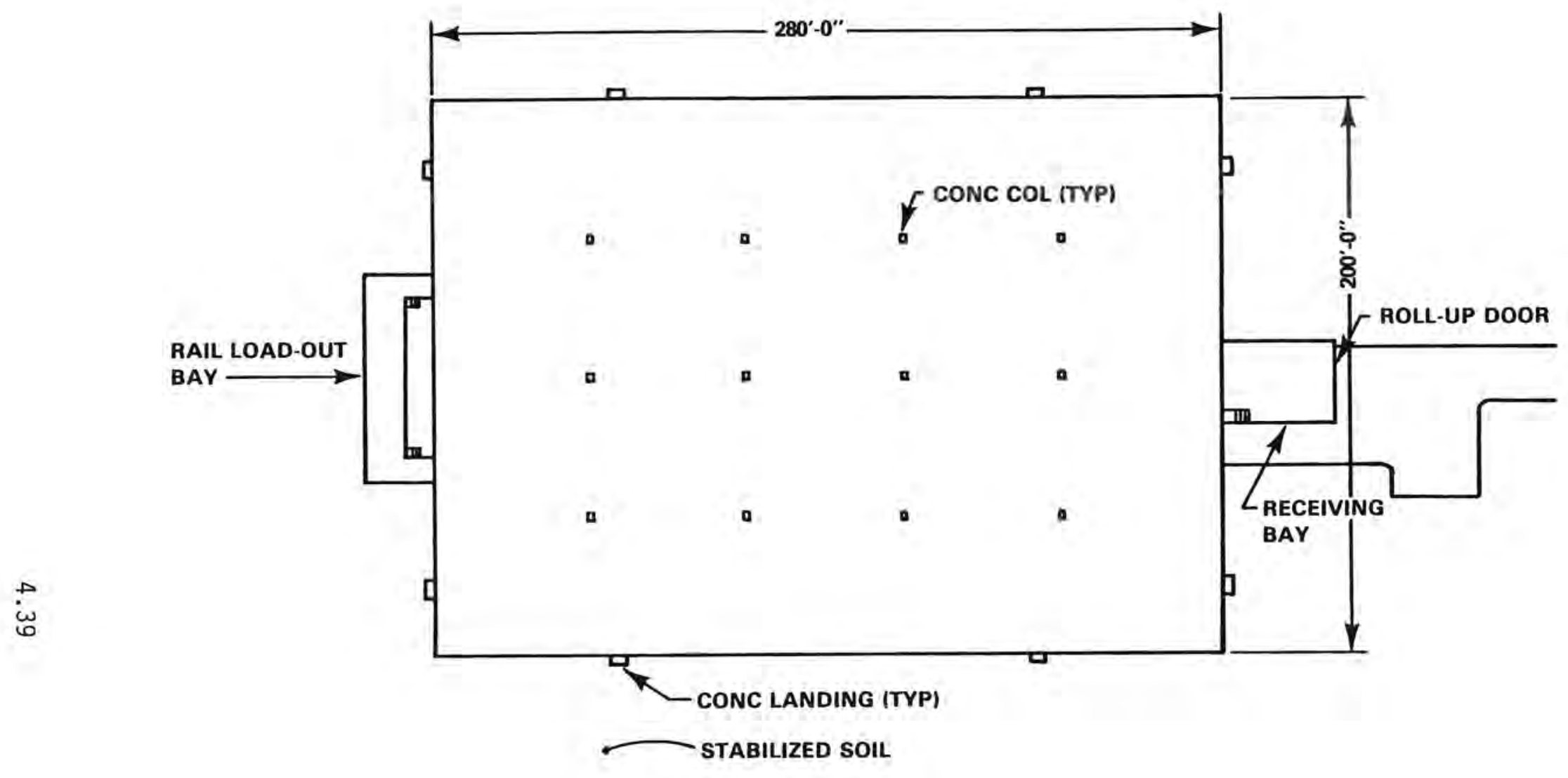

PLAN

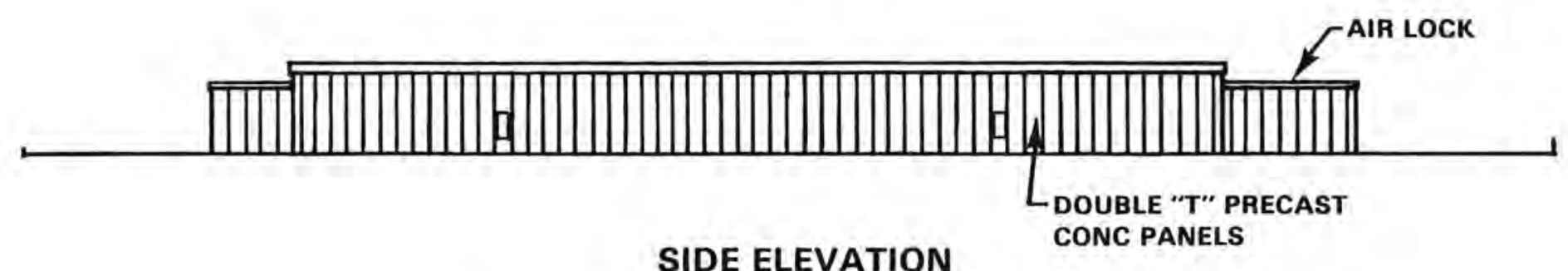

FIGURE 4.13. Transuranic Surface Storage Facility 
IABLE 4.4. MRS Reference Scenario Storage Requirements

Casks

\begin{tabular}{|c|c|c|c|c|}
\hline & MTHM & Containers & Required & Comments \\
\hline Fue1 & 530 & & 54 & $\begin{array}{l}\text { REA-2023 cask, } \\
24 \text { PWR or } 52 \text { BWR } \\
\text { fuel assemblies } \\
\text { per cask }\end{array}$ \\
\hline$H L W-1 \mathrm{ft} \times 10 \mathrm{ft}$ & 11,000 & 4,900 & 350 & $\begin{array}{l}\text { REA-2023 cask, } 14 \\
\text { canisters per cask }\end{array}$ \\
\hline RHTRU $-2 \mathrm{ft} \times 10 \mathrm{ft}$ & & 3,845 & 1,282 & $\begin{array}{l}\text { Concrete cask, } \\
\text { average } 3 \text { containers } \\
\text { per cask }\end{array}$ \\
\hline RHTRU-55 gal & & 4,486 & 408 & $\begin{array}{l}\text { Concrete cask, } 12 \\
\text { drumis per cask }\end{array}$ \\
\hline $\begin{array}{l}\text { CHRTU-55 gal (a) } \\
\text { CHTRU } 4 \mathrm{ft} \times 6 \mathrm{ft} \times 6 \mathrm{ft} \\
(\mathrm{b})\end{array}$ & & $\begin{array}{r}34,076 \\
286\end{array}$ & & \\
\hline
\end{tabular}

(a) Stacked four high, $-35,000 \mathrm{ft}^{2}$ required.

(b) Stacked two high, $\sim 3,500 \mathrm{ft}^{2}$ required.

\subsubsection{Structure}

A precast concrete building is used for the TRUSS facility to meet requirements of containment and protection. The basic function of the building is to shelter waste-storage containers; however, it should also confine and reduce the spread of radioactive material in the event of a container failure inside the facility. A fairly light building with an inward-directed air flow will provide reasonable assurance of meeting this objective. This type structure will also provide ample protection from plausible natural events. Floor and loading bay areas are designed to accommodate the handiing equipment and containers.

\subsubsection{Material Handling and Storage}

The TRUSS facility will receive and store TRU waste packages for ultimate shipment to a federal repository for disposal. These packages will range from 55-gallon drums and similar containers to $4-\times 4-\times 6$-foot rectangular steel 
boxes. Packages will be certified to meet contact-handled waste acceptance criteria for permanent disposal, and will be stored in designated areas in the facility.

Deliveries to the TRUSS facility will nomally be made by truck from the WHF and will be received in an enclosed loading bay which will fully contain the delivery trucks or trailers. The $20 \mathrm{ft} \times 40 \mathrm{ft}$ bay will have roll-up doors leading into the facility and to the outside. During waste deliveries the outer door can be closed to provide weather protection and containment. The loading dock in these bays will match the height of truck or trailer beds to permit forklift unloading and storage operations. Fifty-five-gallon drums will be handled by forklifts equipped with drum handling tongs, and stacked in rectangular modules in designated areas in the building. Drums may be stacked no more than 5 layers high, but the storage arrays may be any convenient length or width. The maximum weight of a drum is $\sim 900$ pounds. Forklifts configured with regular tines will handle TRU boxes and preassembled 6- or 12-packs of 55-galion drums. Such packages may have a maximum size of up to $12 \times 8 \times 8.5 \mathrm{ft}$ and may weigh up to 25,000 pounds. This will require that at least one forklift in the facility have a capacity in excess of 25,000 pounds.

There will be a load-out area on the rear of the facility for loading certified waste packages into TRU-PACTs on trailer beds or rail cars for transfer to the repository. This dock will be completely enclosed to permit forklifts to drive from the interior of the facility onto a trailer or a railcar and load waste packages. The bay will measure $75 \times 25$ feet, and will contain one trailer or rail car at a time. It will have doors on both ends to permit forward movement of trailers or rail cars after loading, thus allowing the next carrier to follow directly behind.

\subsubsection{Retrieval}

Drums and boxes from the TRUSS facility will be retrieved with forklifts. There is no preliminary work required to make the containers accessible. They can be moved out of the facility and onto trucks at the loading bays, which is essentially the reverse of the delivery and emplacement 
operations. The favorable storage environment will insure that containers will be in good condition at retrieval and not require repackaging, an extra operational step that would add to the cost of TRU retrieval. In short, the TRUSS facility can provide inexpensive TRU retrieval because of:

- immediate access to the waste containers

- avoidance of the need to repackage or contain the original waste containers

- small retrieval crew, using efficient eqipment and techniques.

\subsubsection{Storage Environment}

The TRUSS facility provides a favorable storage environment. The walls and roof will be precast concrete panels with insulation sandwiched inside. Insulation $R$ values of about 11 to 13 for the walls and 19 for the roof will be used. Artificial temperature control requirements are minimized by the inherent thermal stability provided by the structure and concrete slab floor, and by the wide storage temperature range allowed for the waste. The ventilation exhaust system will also help lower the temperature if required for personnel access. No firmly established low temperature limit will be set but the temperature will be high enough to avoid formation of frost on the storage containers. This will be accomplished in the TRUSS facility by using the interior lights to heat the storage space as necessary.

The relative humidity inside the TRUSS facility will be below critical levels for the vast majority of the storage periods, even without mechanical dehumidification equiment or heating. Studies show that the mean ambient relative humidity at Hanford is at, or below, 55 percent for 7 months of the year, and ranges between 60 and 80 percent for the other 5 months. By maintaining the internal TRUSS storage temperature $10^{\circ} \mathrm{F}$ above the outside temperature in the winter time, the resulting relative humidity will not exceed 55 percent.

\subsubsection{Criticality Prevention}

Storage of fissile material in the TRUSS facility will be done in arrays that make efficient use of the facility and will not permit criticality to 
take place. Because of the quantity and form of fissile material that will be placed in the facility and its form and arrangement, the facility will be classified as a Limited Control Facility. As such, criticality monitors are not mandatory, but may be incorporated along with other fissile facility requirements as deemed prudent.

\subsubsection{Radiation Monitoring}

Radiation monitoring and alam systems will be provided in the TRUSS building, in the ventilation stack, and exterior to the building, to detect any inadvertant releases.

\subsubsection{Lighting}

Skylights may be installed to augment the installed energy-efficient fluorescent lighting. The number and location of skylights will be determined during conceptual design. The skylights will minimize the electrical power requirements during normal working hours only. During non-normal hours or inclement weather the fluorescent lighting must be able to provide 100 percent of the lighting needed, plus heating requirements.

\subsubsection{Fire Detection and Suppression}

Fire alarm control boxes will be provided near the loading bay areas to permit manual activation by operating personnel. The general storage area inside the facility will be equipped with a smoke detection system and an automatic sprinkler system, both of which will signal the fire department upon activation.

A dry-pipe, water sprinkler system will provide fire suppression capability throughout the facility. A dry-pipe system is required because the facility is unheated. A fire main will be required to bring the fire fighting and sprinkler system water to the facility. If the sprinklers are activated the drain system will collect the runoff water and route it to a holding tank. Hand-held fire extinguishers should be provided in accessible areas, but consideration should be given to selecting these locations to permit routine monthly inspection and maintenance when the facility is locked. 


\subsubsection{Ventilation}

The facility will be equipped with a ventilation exhaust system to provide negative pressure ventilation within the building. The system will be sized to ensure that the normal air flow through the facility doors and openings is directed toward the inside. It will have a single exhaust stack, equipped with a motor-driven damper interlocked with the exhaust fans. The stack will have an isokinetic sample probe leading to a record and alarm monitoring system. The monitoring system will automatically shut down the ventilation system if air particulate levels reach preset limits. Alarms for the stack monitoring system will be displayed locally on an annunciator panel outside of the facility, and remotely in the WHF.

Because of the inherent thermal stability of this type of structure, ventilating with outside air will be sufficient to provide an acceptable working environment inside the facility during the summer. Material handling will not be a full-time operation, the main function being storage. Cooling for personnel comfort will be limited to keeping the peak globe temperature (WBGT) below $89^{\circ} \mathrm{F}$, which can easily be accomplished without air conditioning. Sufficient heat will be generated from the lighting to provide a moderate temperature during the winter to prevent freezing.

\subsubsection{Transfer and Storage of Remote-Handled Wastes - Casks}

The interim storage provisions for the material received at the MRS/IS facility encompass an enclosed building (TRUSS) and either below-ground drywells or casks located on the surface. This section describes the cask storage concepts.

Two different types of storage casks are used. The REA-2023 cask, shown in Figure 4.14, is the reference cask for fuel and HLW storage, and has been designed, but not yet built. The unit consists of a double containment design with a welded final closure. The various components include a rugged, smooth stainless steel outer skin, a lead gamma shield, a water neutron shield and a basket featuring boral neutron-absorbing plates. The primary containment vessel is also stainless steel, designed according to ASME Boiler and Pressure Vessel Codes. This cask is compatible with loading and unloading procedures 


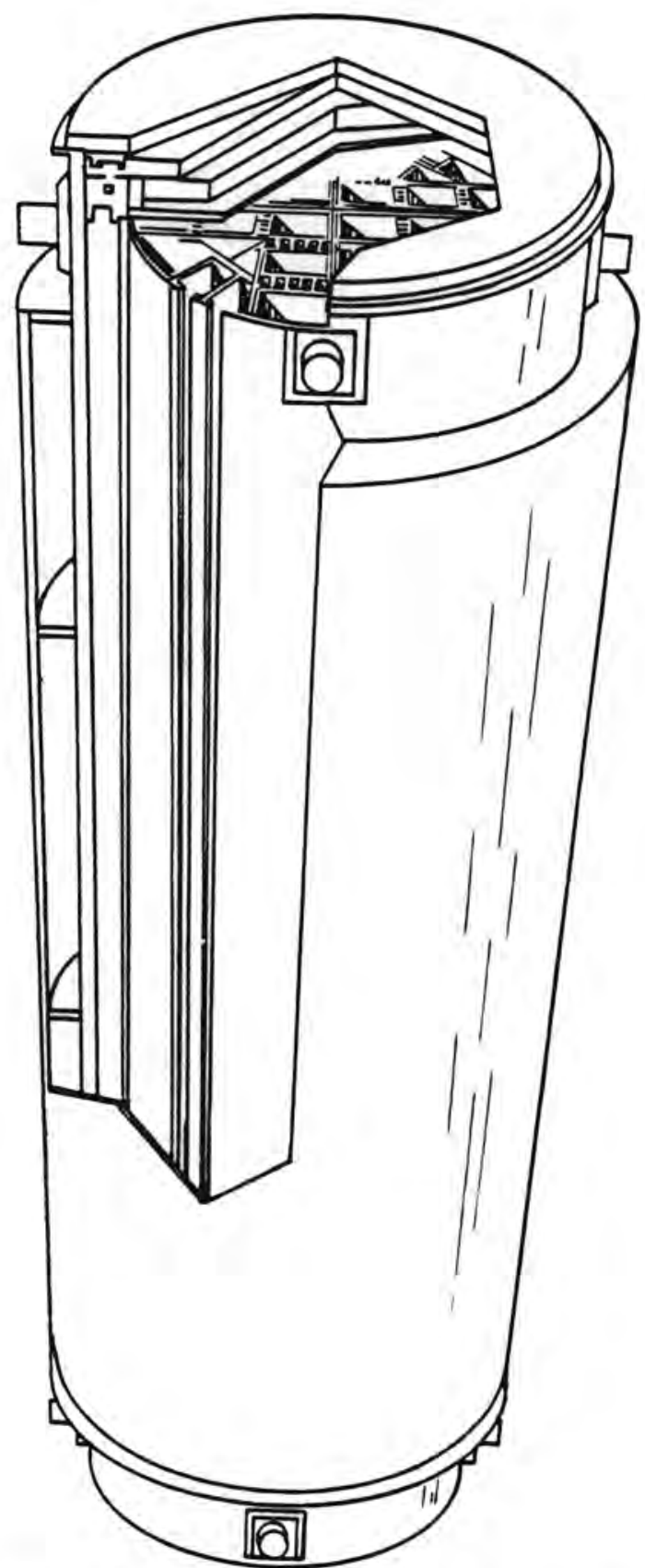

FIGURE 4.14. The Reference Passive Cooling Dry Storage Cask 
which are common to utilities. Handling is accomplished by a redundant lifting yoke and two sets of lifting trunnions. An additional set of pivoting trunnions is also used. The cask can be handled and stored in either a horizontal or vertical attitude. Design permits continuous monitoring of both primary and secondary containment as discussed in Section 4.3.3.4. Cask design data are shown in Table 4.5. This cask is 8 feet in diameter by 16 feet long and weighs about 100 tons.

For storage of RHTRU, reference concrete casks, as shown in Figure 4.15, are used. The concrete casks are up to 9 feet in diameter by 16 feet long and weigh up to 90 tons. Different bore sizes and shielding thicknesses are used to accommodate different cask payloads, which vary from 1- to 2-foot diameter by 10-foot long RHTRU canisters to twelve 55-gallon drums.

The same handling, unloading and storage system is used for all casks. This system uses above-ground storage on reinforced concrete pads. A typical storage yard is 200 feet by 1850 feet and can accommodate about 1000 casks on a nominal 20-foot spacing. A tractor-trailer with pneumatic tires is used to haul the casks from the WHF to the storage yard. A gantry crane or a truck-mounted crane are located in the storage yard for unloading the casks from the trailer onto the storage pad.

Typical radiation levels of the material to be stored are shown in Table 4.6.

TABLE 4.5. Reference Metal Storage Cask Design Data

$\begin{array}{ll}\text { Designer/manuf acturer } & \text { REA } \\ \text { Mode1 } & \text { REA-2023 } \\ \text { Capacity - PWR assemblies } & 24 \\ \text { Weight, loaded, tons } & 52 \\ \text { Size } & 87.5-97.5 \\ \text { Age of fue 1, years } & 8 \mathrm{ft} 00 \times \text { up to } 16 \mathrm{ft} \\ \text { Thermal load, kW } & 5 \\ \end{array}$

(a) Can be increased to $47 \mathrm{~kW}$ by addition of special fins. 


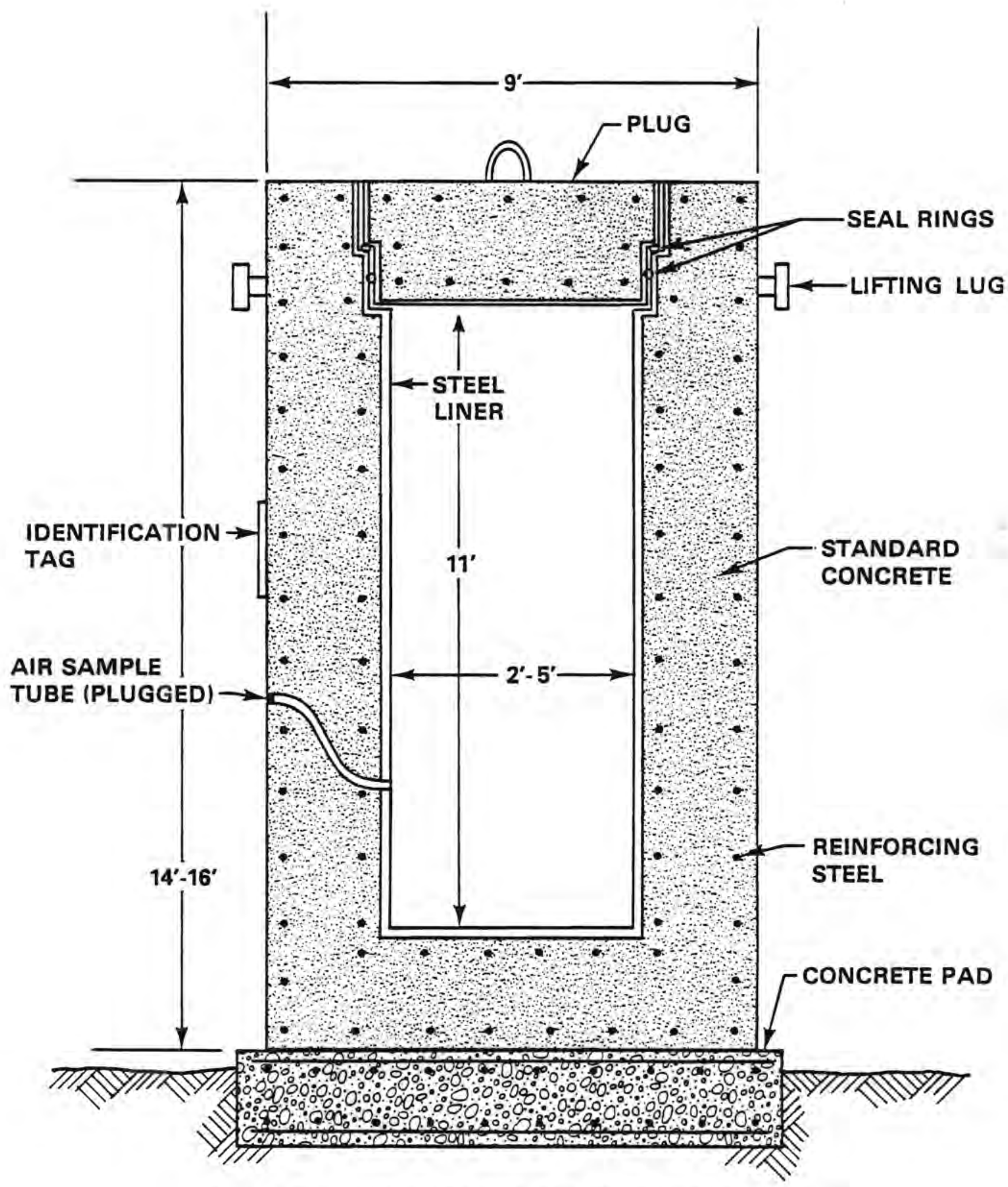

FIGURE 4.15. Concrete Cask for RHTRU Waste Storage 
TABLE 4.6. Typical Surf ace Radiation Levels of Remote-Handled Material

Fue1 Assemblies

HLW Canisters

Hu 11s, compacted

Hardware

RHTRU 1-ft dia x 10-ft can

RHTRU 55-gallon drums

\begin{tabular}{clllll}
$\mathrm{R} / \mathrm{hr}$ \\
\hline$\underline{0.2-5}$ & $\underline{5-50}$ & $\underline{50-500}$ & $\underline{1,000}$ & $\underline{50,000}$ & $\underline{100,000}$ \\
\end{tabular}

A) 1

A11

\subsubsection{Surface Cask Storage}

After a cask storage unit is filled in the WHF, it is loaded onto a pneumatic-tired transport trailer and towed into the cask storage area by a wheel tractor. The storage area is served by a mobile yard gantry crane, which spans two rows of storage units with an aisle between the rows for transport trailer access. This allows the gantry crane to unload a storage unit on either side of the transport trailer, as shown in Figure 4.16. In the storage area, the transport trailer meets the yard gantry crane at the placement site, where the gantry crane attaches to the storage unit by means of a cab-controlled power-operated load grab, lifts the cask unit clear of the trailer bed and places the unit in final position on its preconstructed concrete foundation pad. While performing the unloading operation, the gantry crane stands on power-operated stabilizing jacks and operates as a fixed gantry. The storage unit is handled intact and is lifted no more than 4 feet above the ground to minimize the potential for cask damage in the event of a dropped load.

The empty transport trailer is returned by tractor to the WHF for reloading. Since the trailer is of the four-wheel trailer type, it can be separated from the tractor, parked, and retrieved later or taken directly through the system, whichever pattern of operating practice is most advantageous.

The overall average transport travel speed is 4 to $5 \mathrm{mph}$. Slower speeds will be used when traveling between storage units in the storage area and 


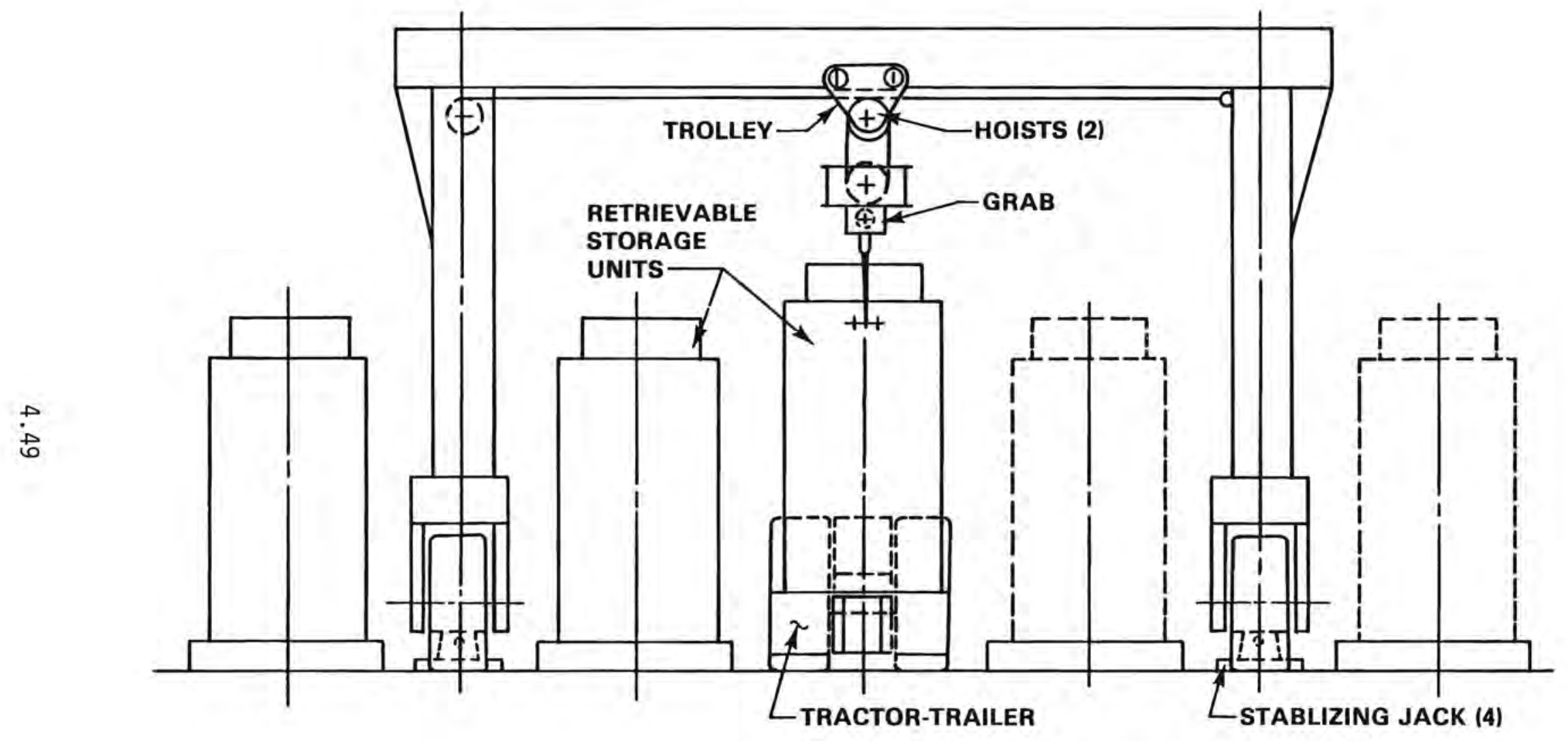

FIGURE 4.16. Yard Gantry Crane 
higher speeds can be used when traveling empty on main roads. The nomal time required for a complete round trip of a transport tractor-trailer for delivery, including placement of a storage unit into the storage area by the crane, is estimated to be 2 hours or less, based on the longest distance to be traveled in the ultimate facility. For early years, a round trip time of 1 hour or less can be expected.

The yard gantry crane is sufficiently mobile, traveling on pneumatic tires at about $2 \mathrm{mph}$ average, to serve the storage area and also to assist in the unloading of inbound shipments.

The transport and yard gantry crane system can retrieve any storage unit from any position in the storage area by reversing the procedure of the normal delivery. The storage area aisles provide unlimited access to any single storage unit, and retrieval cycle time will be comparable to the delivery-placement cycle time. To protect the storage unit against upset due to credible seismic or wind forces during transport and placement, the trailer is designed for stability, and both trailer and gantry crane are provided with antidrop skids to limit trailer or gantry drop in case of tire failure.

Because the surface radiation levels on the casks may be as high as $20 \mathrm{mr} / \mathrm{hr}$, some local or limited shielding may be required to allow safe approach by personnel and equipment for recovery from equipment malfunction or failure during the placement operations.

\subsubsection{System Arrangement}

For the waste casks, the storage area is subdivided into lots of -1000 storage units. The array spacing within each lot, to provide $400 \mathrm{ft}^{2}$ for each storage unit in conformance with design limitations for handling operations is as follows (center-to-center of storage units):

- parallel to travel of transport trailer and yard gantry crane spacing alternately $21 \mathrm{ft}$ to $27 \mathrm{ft}$.

- transverse to travel of transport trailer and yard gantry crane spacing nominally $16 \mathrm{ft} 8 \mathrm{in}$. 
This spacing provides alternating wide aisles, 15 feet minimum width, for transport tractor-trailer movement and narrow aisles, 9 feet minimum width, for yard gantry crane movement. These widths will also serve possible future larger storage units with storage unit foundation pads 12 feet in diameter. The aisle widths provide for free movement of maintenance and surveillance vehicles and personnel. The gantry crane, trailer and cask arrangement during unloading are shown in Figure 4.17.

The above arrangement and spacing are based on the reference 8 to 9 foot diameter casks, but they can be modified to accommodate casks with different sizes (within reasonable limits). Different cask sizes would only change the internal array arrangement and not the land usage of the storage system.
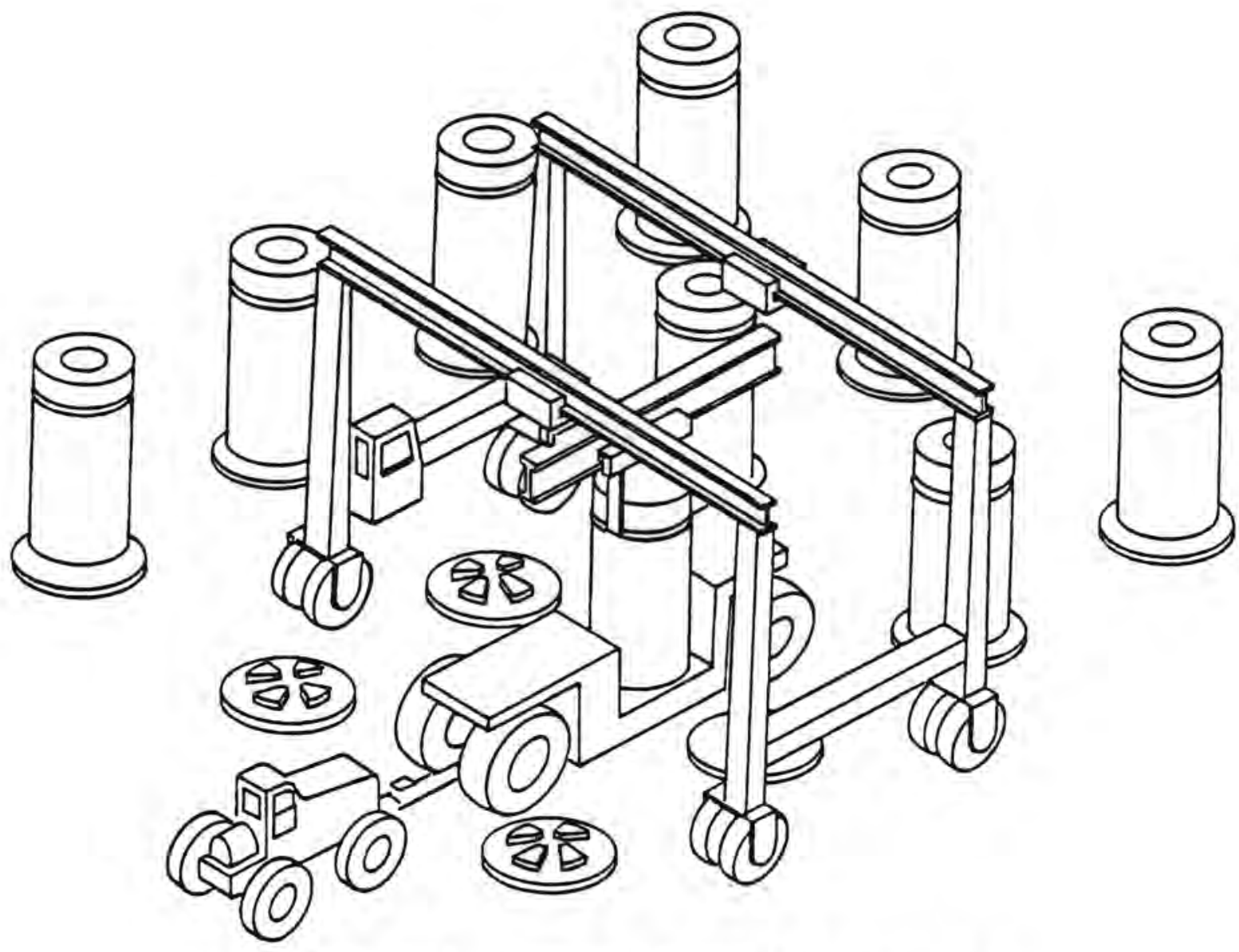

FIGURE 4.17. Surface Storage Cask Unloading 
Between storage area lots, aisles of 90-foot width are provided to facilitate large-radius turning of the transport tractor-trailer and straight alignment of the transport trailer with the aisles in the lots. The wide aisle also provides ample space for turning and travel of the yard gantry crane. This arrangement provides for drive-through operation of the transport tractor-trailer, avoiding complex maneuvers or backing. The storage area layout in relation to the WHF is shown in Figures 4.6 and 4.7 .

The initial storage area fence will enclose an area capable of storing waste through the year 1995 . The initial construction will consist of about 50 foundation pads, which is the number required for the first 5 years of facility operation for the Reference scenario.

\subsubsection{Component Description}

Foundation pads for support of the waste storage units are poured in place. The pads are octagonal, circular or three smaller square reinforced concrete slab on grade, approximately 18 inches thick. After construction of the initial 50 pads, they will be built in quantities dictated by the placement schedule.

The area between storage pads, and the lightly traveled portions of the wide aisles between lots, are treated with defoliant, graded, and surfaced with 8 inches of crushed rock. This surface is considered adequate for travel by the transport equipment and yard gantry crane equipped with wide base earthmover-type pneumatic tires, and for use by surveillance and maintenance vehicles. The main roadway portions of aisles, where repeated and heavy traffic is expected, and feeder and collector roadways traveled by the transport equipment are 10 inches of compacted aggregate over a prepared and compacted subgrade.

The transport trailer is a 110-ton capacity, low bed, four-wheel trailer, running on wide base earthmover-type pneumatic tires. Skid rails are provided along each side, $\sim 6$ inches clear of the ground, to support the trailer in case of flat tires. Shielding is built into the trailer bed frame to supplement the limited shielding in the bottom of the storage casks. Initial equipment complement is one trailer. 
The tractor for the transport trailer is a four wheel, pneumatic-tired, diesel-engined unit tractor which has electric power and lighting to support night operation in the storage area. Initial equipment complement is one tractor.

The mobile yard gantry crane is a self-contained, self-propelled, straddle-type lifting system, with rated lifting capacity of 110 tons when stationary on stabilizing jacks.

The gantry main structure comprises two portal frames, each with under-running hoist trolley and hoist. Normal load pickup is by means of power-operated cab-controlled load grab. The load grab is carried by a longitudinal spreader which has a hoist load block built into each end and which incorporates a power-operated load-shift device to provide $\sim 2$ feet longitudinal load movement for spotting loads when the gantry is standing on the stabilizing jacks. Operator's cab and engine power unit are mounted on the side frame between the wheels. The four wheels have single wide-base, earthmover-type pneumatic tires. Other features include power-operated stabilizing jacks; skid rails to limit drop to 6 inches in case of flat tires; electric power and lighting to support night operation in the waste storage area. Initial equipment complement is one mobile yard gantry crane.

\subsubsection{Cask Monitoring System}

A monitoring and surveillance program will be implemented and maintained throughout the life of the storage area. The REA cask, described earlier, consists of a double containment design with a welded final enclosure. REA cask design permits continuous monitoring of both primary and secondary containment. Utilization of a pressure sensor permits continuous signal transmission and automatic sensing and recording by a multipoint interrogation system for the secondary containment system. Each cask wi1l be sampled on an established basis for pressure and airborne activity through a sample valve. In order to detect any abnomal thermal conditions, the temperature of the exterior of the casks will also be monitored on an established basis.

Monitoring and service trucks with portable themocouple and pressure readout and recording instrumentation, pressure gauge and gas sampling 
manifolds, and sample bottles will be used to periodically measure the environment within each cask. Cask air samples will be withdrawn into an evacuated sample bottle and analyzed in the WHF laboratory for evidence of leakage from the stored fuel or HLW packages.

Measurement of the cask exterior surface temperature will provide an indirect measurement of the fuel element temperature and will simplify the cask design and fabrication by avoiding a thermocouple penetration through the cask pressure boundary.

Because the partial pressure of the air in the cask will increase during the first few months after packaging (due to an increase in temperature), the pressure will be monitored at frequent intervals during this period.

Excessive pressure, if any, will be relieved through a sampling manifold into an evacuated waste-gas cylinder.

\subsubsection{Transfer and Storage of Remote-Handled Wastes - Drywells}

Below-grade drywells could be utilized as a means and method for the interim storage of waste requiring major shielding and isolation. If RHTRU waste packages of a configuration not compatible with drywell dimensional limits are received, they could be stored in concrete casks as previously discussed.

Drywe11 passive storage would consist of 30 - and 18-inch-diameter steel pipe extending about 24 feet below the ground, as shown in Figure 4.18. The ground provides shielding from radiation and permits dry heat dispersion by conduction through the surrounding soil to the atmosphere. The bottom of the pipe is sealed by welding and the top of the drywell is sealed by gasketing or welding. A small sealed tube is provided for sampling the arywell interior on a periodic basis for airborne activity.

\subsubsection{Transportation and Placement Systems}

After a drywell package, which would typically contain three BWR fuel elements, one PWR fuel element or one HLW canister, has been either prepared or checked out in the WHF, it and sand shielding material will be transported 


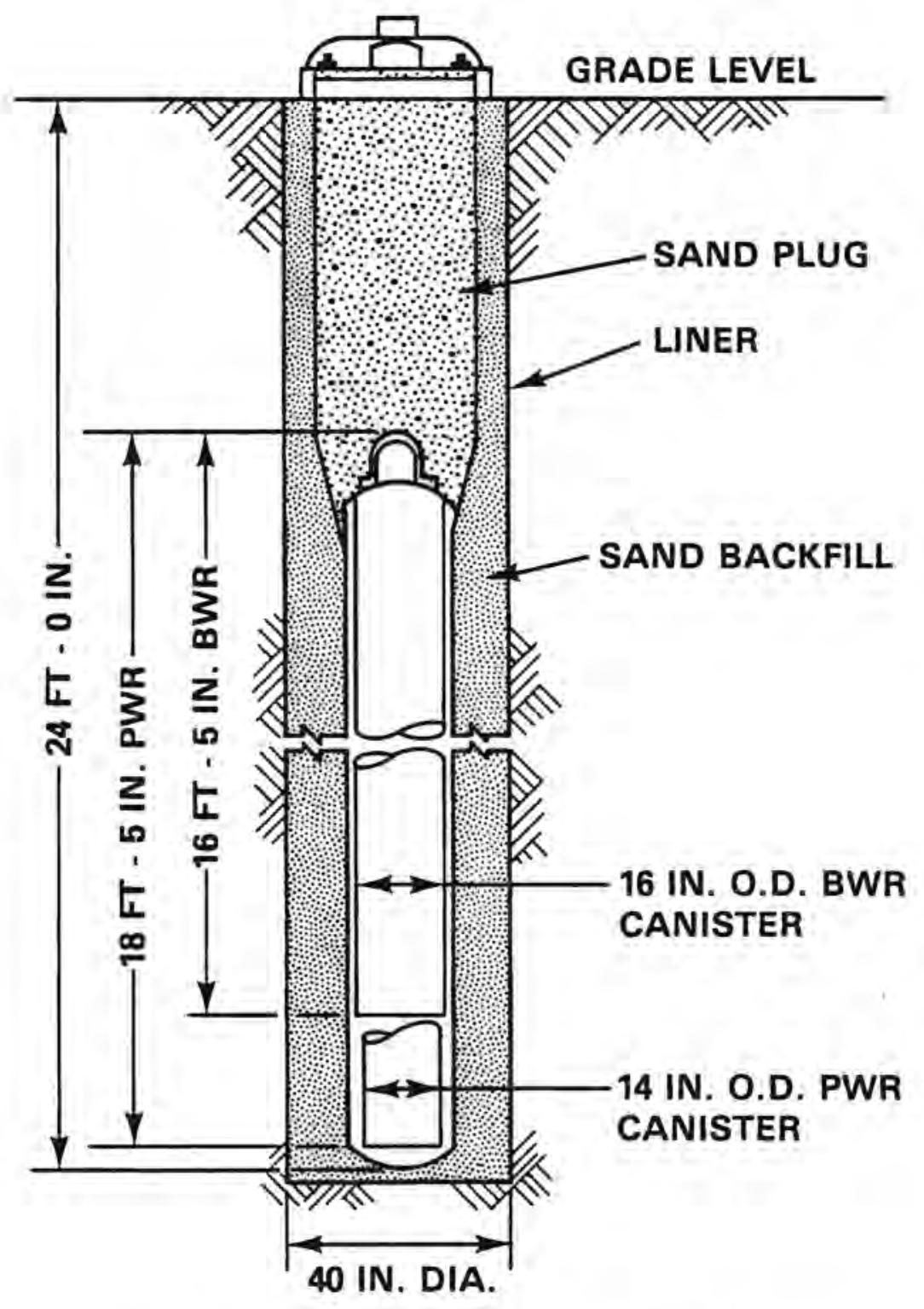

FIGURE 4.18. Reference Drywe11 Encasement

to the storage area in a shielded cask transporter vehicle. The sequence of the canister placement operations, as illustrated in Figure 4.19, will be in three major steps: drywell preparation, package placement, and completion of placement. These placement activities may be described as follows:

- A cask-positioning fixture will be installed over the drywell to facilitate alignment of the transporter cask on the drywell centerline. 


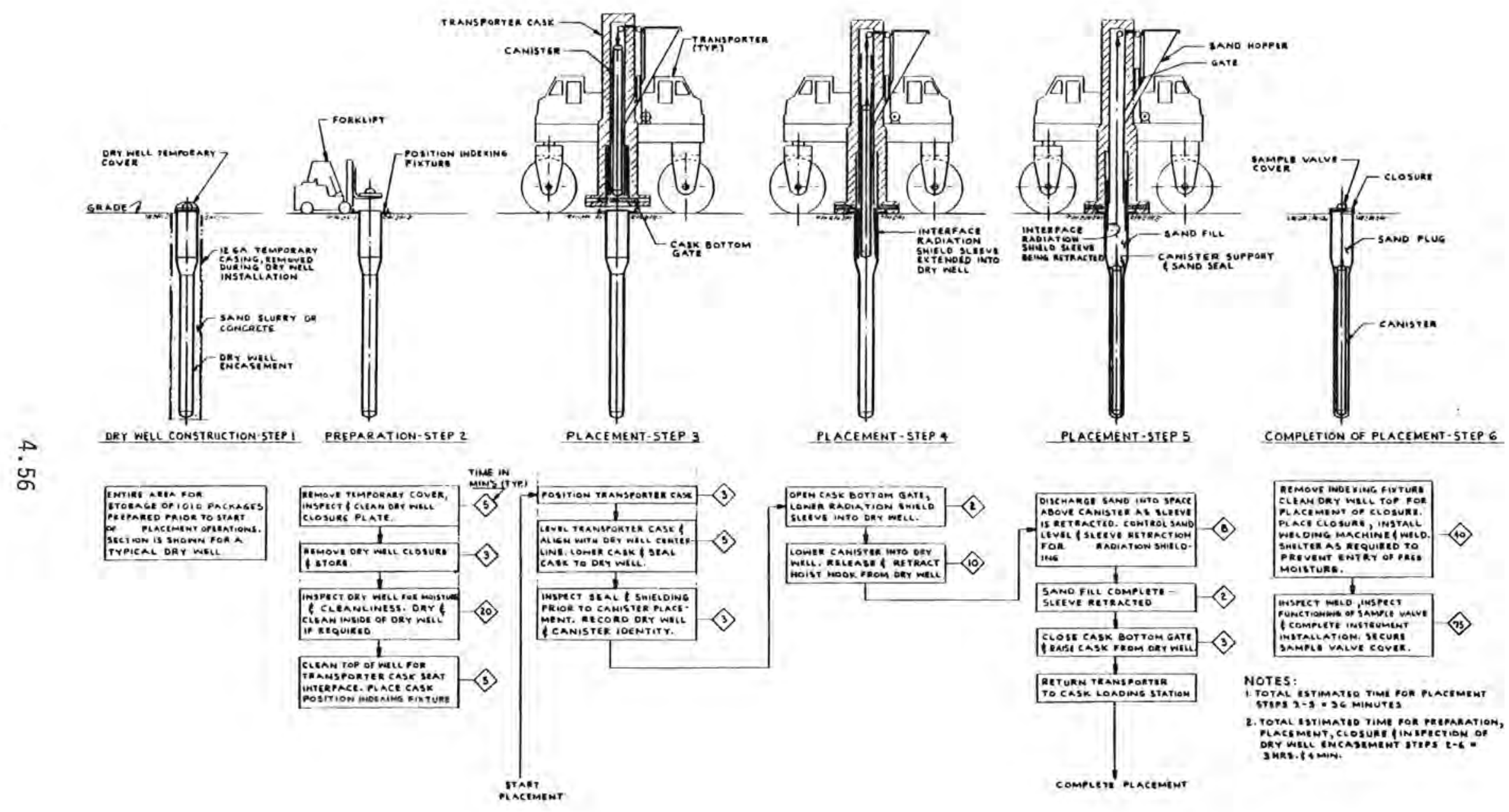

FIGURE 4.19. Drywell Canister Unloading Sequence 
- The transporter vehicle will be driven into position over the arywe11 for placement of the package. The bottom gate of the transporter cask will be opened and a radiation shield sleeve, located inside the cask, will be lowered into the drywell. The package or canister, attached to a grapple, will be lowered by a hoist mechanism built into the transporter cask.

- After the package has been placed in the drywe11, $30 \mathrm{ft}^{3}$ of sand will be discharged from the transporter sand hopper into the space above the canister to fill the upper compartment of the drywell. As the sand fills the compartment, the radiation shield will be retracted into the shield cask.

- Upon completion of these tasks, the transporter cask will be lifted into the transport position and the cask bottom gate closed. The transporter will then return to the WHF loadout station for another package.

- The cask positioning fixture will be removed and relocated to the next drywell scheduled for package placement. The closure plate will be bolted or welded to the top of the drywell encasement.

The transporter will be supported by and will travel on large earthmover-type pneumatic tires. The transporter speed will be 1 imited to a maximum 10 miles/hour.

The fuel and HLW canisters will be shielded by a vertical, cylindrical bottom-loading cask mounted on the transporter. The cask will be complete with a hoisting mechanism and a grapple device to permit vertical loading and retrieval of the canister.

The transporter will be equipped with positioning mechanisms for vertical, horizontal, and angular adjustment of the cask for alignment with the drywell centerline. The transporter will be capable of handling a package with maximum dimensions of $18 \mathrm{ft} \mathrm{5-1/2}$ inches in length and 16 inches in diameter. The heaviest package weight wi11 be $\sim 3850$ pounds. 


\subsubsection{Drywell Storage Field}

Each drywe11 consists of a cylindrical carbon-steel package encasement vessel that projects $\sim 6$ inches above and extends $\sim 24$ feet below the ground surface, as shown in Figure 4.18. The encasement vessels will be shop-fabricated of 18-inch- and 30-inch-diameter pipe joined by a pipe reducer. The encasement will be closed at the bottom by a pipe cap welded onto the 18-inch-diameter lower section of the encasement. The closure plate on top of the encasement vessel will be either field welded to the encasement or bolted to provide secondary containment after placement of a package.

The drywells in the storage area will consist of vertical steel encasements buried in the ground in a rectangular array, with a uniform 17-foot center-to-center spacing for spent fuel assemblies and a 44-foot spacing for HLW canisters. The initial storage field for fuel will contain about 1110 drywe11s, with primary and secondary road systems for package transport, support equipment, and security vehicles.

The storage area will be expandable by modular construction of arywells to ensure a minimum availability of 1 year of storage capacity in advance of ongoing storage operations. It is assumed that the conductivity of the soil will effectively transfer $1 \mathrm{~kW} / \mathrm{hr}$ of thermal decay heat from the spent fuel packages to the atmosphere on a 17-foot spacing. However, to facilitate the transfer of the $2.3 \mathrm{~kW} / \mathrm{hr}$ decay heat from the HLW packages, an 11- to 12-inch blanket of a more highly conductive material (e.g., concrete) will be placed around the drywell encasements that are on 44-foot spacings.

\subsubsection{Drywell Monitoring}

A monitoring and surveillance program will be implemented and maintained throughout the life of the drywell field. Design permits continuous monitoring of the interior of each drywell. Utilization of a pressure sensor permits continuous signal transmission and automatic sensing and recording by a multipoint integration system. The interior of each arywelt will also be sampled on an established basis for airborne activity through a sample valve located on top of the drywell closure. In order to detect any abnormal 
thermal conditions, a thermocouple will be provided on the exterior of selected drywell encasements for periodic measurements of the temperature within the drywell.

Monitoring and service trucks with portable thermocouple and pressure readout and recording instrumentation, pressure gauge and gas sampling manifolds, and sample bottles will be used to periodically measure the environment within each drywell. Encasement air samples will be withdrawn into a sample bottle and analyzed in the WHF laboratory for evidence of inert gas leakage from the stored packages.

Measure of the drywell encasement exterior surface temperature will provide an indirect measurement of the fuel element temperature and will simplify the encasement design and fabrication by avoiding a thermocouple penetration through the encasement she11.

The pressure in each drywell will also be measured on a scheduled basis to detect any abnormal changes in pressure. Because the partial pressure of the air in the encasement will increase during the first few months after package placement (due to an increase in temperature), the pressure will be monitored at frequent intervals. Excessive pressure will be relieved through a sampling manifold into an evacuated waste-gas cylinder.

\subsubsection{Service Facilities}

In addition to the WHF and the storage areas, other support and servicing buildings and facilities as shown in Figures 4.6, 4.7, and 4.20 will be provided for the efficient and safe operation of the NRS/IS facility, first in its role as interim storage and later as the basic surface facility for the co-located repository. Because of the existence and close proximity to various services such as fire and emergency vehicles, no site-specific facilities are provided for these.

\subsubsection{Administration Building}

A one-story building of 6000 to $8000 \mathrm{ft}^{2}$ provides office and storage space for the onsite administration, quality assurance, safety, and engineering personne1, provided overall administrative functions are conducted in other existing Hanford Site buildings. 
FACILITY INDEX

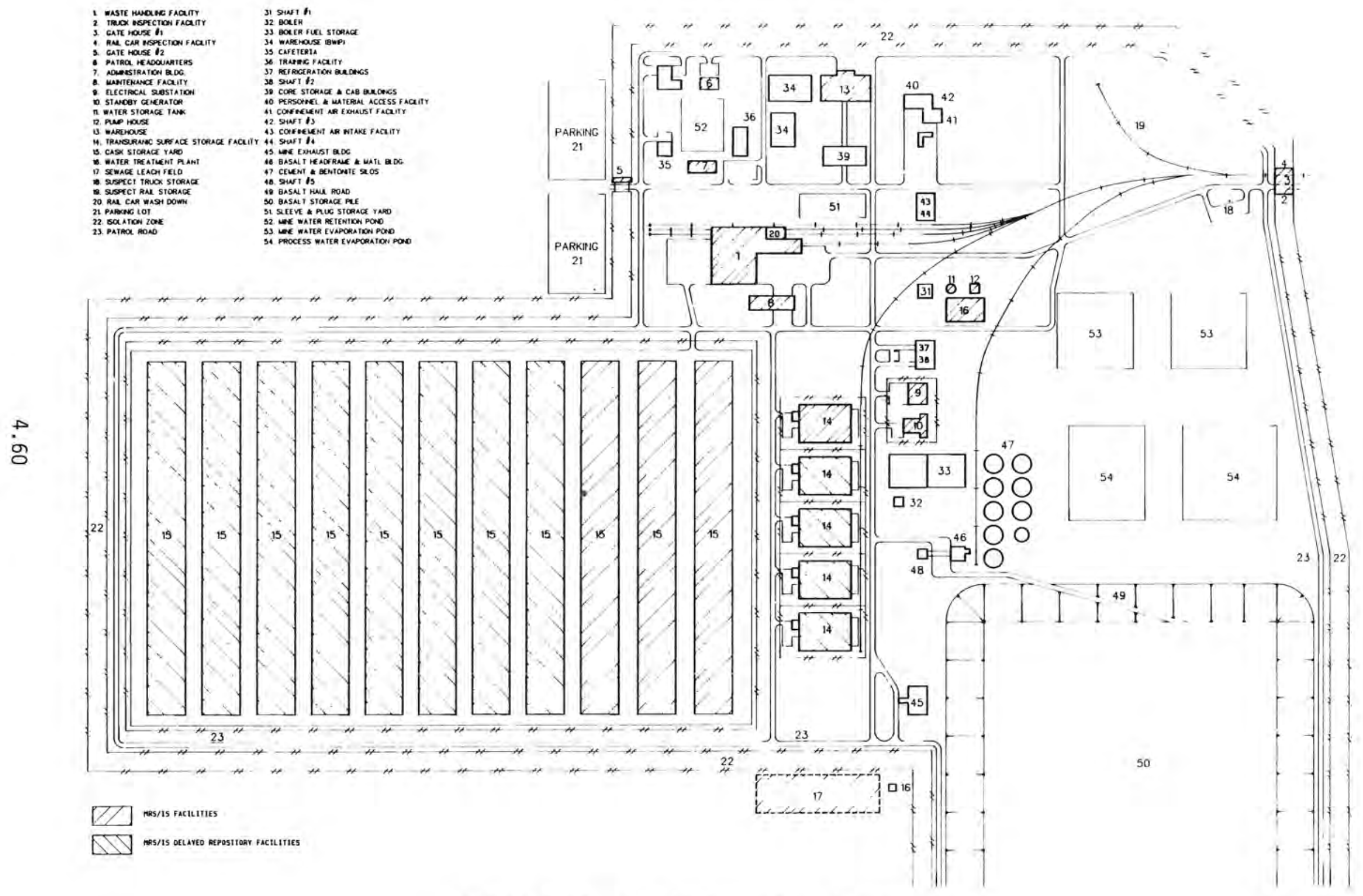

FIGURE 4.20. MRS/IS/Repository Arrangement 


\subsubsection{Maintenance Building}

A one-story building of about $15,000 \mathrm{ft}^{2}$ provides the supporting shops and associated shop storage for the MRS/IS operation.

\subsubsection{Material Warehouse Building}

The material warehouse, a building of varying heights, consists of two functional portions: a high bay building of about 50 feet high and a low bay for administrative and small equipment storage. The total building has about $20,000 \mathrm{ft}^{2}$. The high bay portion of the building has a bridge crane for handling operating supplies and spare equipment for the WHF and other support buildings. Forklift truck access will be provided for stacked pallet racks and floor storage areas. Also, areas will be provided for outdoor storage of large equipment items.

\subsubsection{Gate Houses}

There are two, one-story gate house buildings for the area. The first provides a security check area for entering employees and visitors and the second is for rail car and truck shipments. Truck inspection and rail car inspection pits are provided adjacent to the second guard station.

\subsubsection{Service Utilities}

Water, electrical power, roads and railways to the MRS/IS facility are assumed to be available from sources on the Hanford Site. Descriptions of these utility systems plus several in-area systems are given below.

\subsubsection{Water Supply}

The water supply system delivers water to the required in-plant systems; these include the raw water system, water treatment, water storage, water distribution and the fire protection system. Raw water will be received from an existing export line pumping station. A water treatment plant is provided for a sanitary water supply. Distribution pumps will maintain a 100 psig nomal distribution network for sanitary and process use.

The fire protection system will include a 250,000-gallon water tank and two fire pumps discharging into the facility water distribution network 
supplying fire hydrants, sprinkler systems and fire hoses. One pump will be electric-motor-driven and one will be diesel-engine-driven.

\subsubsection{Electrical Power Systems}

Normal and emergency standby power systems will be provided. Offsite power will be obtained at 115 or $230 \mathrm{kV}$ and will be brought to a new substation that will reduce the voltage to $13.8 \mathrm{kV}$. Dual electrical feed systems to the substation are planned for maximum reliability. From the main substation the power will be distributed to the various building and centers via $13.8 \mathrm{kV}$ direct burial cables.

Emergency standby power will be provided to vital systems by means of a turbine generator set. An essential function of this system is to restore power to those essential loads which must maintain safety functions but can accept short duration interruption in power. Uninterruptable power will be supplied by batteries to those systems that cannot accept short duration interruptions.

\subsubsection{Sanitary Waste Disposal System}

A sanitary waste disposal system will be provided to collect, treat, and dispose of a maximum flow of 10,000 gallons/day of sanitary waste generated at the proposed facility. Sewage collection will be through an underground gravity pipe system. The sewer pipe will be laid under 4-1/2 feet of earth cover for frost protection. Sewage will be treated in a prepacked, extended aeration, biological treatment plant which will meet all local, state and federal effluent discharge standards. Effluent from the treatment plant will be discharged to an offsite subsurface tile drainage field. Wastes from potentially, radioactively contaminated sources will not be discharged to the sanitary waste disposal system, but will be treated within the facility waste treatment system.

\subsubsection{Communications and Fire Alarm System}

Communication systems for the facility will include a PA system, a plant intercom system, and telephone systems for both inside and outside calls. 
Security communications will be handled primarily by the Hanford Site radio system. Evacuation, radiation alert, and fire alarm systems also will be provided.

The PA system will be used for paging and for emergency instructions within the WHF, including the storage fields. Paging may be done from designated telephones as well as from the emergency communications center in the Patrol Headquarters building.

The fire alam system will be transmitted directly to the fire station as well as sounding local alarms to warn personnel to evacuate.

\subsubsection{Radiation Monitoring and Surveillance}

Radiation monitoring will be conducted both inside and outside the buildings and in the storage yards to assure that radiation levels and airborne particulate levels on or about the facility or area do not exceed preset limits. Monitors located in areas frequented by onsite personnel will have local alarm capability. Other monitors and monitoring devices will be under continuous surveillance at the environmental console or will be periodically checked by health physics personnel.

Area and perimeter monitoring will be accomplished with continuous air monitors (CAMS) and ion-chamber-type dosimeters strategically placed around the outside boundary of the site to provide continuous monitoring of the immobilized spent fuel and remote handled wastes. The heaviest concentration of units will be located downwind from the facility. The CAMs will be of the fixed-filter type and designed to withstand exposure to adverse elements of the environment.

Preliminary radiation monitors will be placed strategically around the outside boundary of the site. The heaviest concentration of units will be located downwind of the prevailing winds. Three types of monitors will be used: area gamma monitors, beta-gamma particulate monitors, and thermoluminescent dosimeters. 


\subsection{COST ESTIMATE AND SCHEDULES}

This section contains the estimated cost for the MRS/IS facility, and the bases for developing life cycle costs for the scenarios described previously. Cost estimates are based upon the use of constant unescalated 1982 dollars. Construction schedules are adjusted to satisfy the needs as specified in the scenarios.

\subsubsection{MRS/IS Facility Base Cost and Construction Schedule}

It is estimated that detailed design will require 30 months. Construction will overlap the design by 1 year and is estimated to continue for 4 years. Total time from authorization to hot operation of the facility is estimated to be $51 / 2$ years. The design and construction schedule is shown in Figure 4.21 .

It is assumed that the facility is constructed during the period 1985 to 1990. The disbursement schedule associated with this construction time table is: a 5 percent expenditure in 1985, a 15 percent expenditure in 1986, a 20 percent expenditure in 1987, 25 percent expenditures in 1988 and 1989, and a 10 percent expenditure in 1990 .

The estimated cost to design, construct and outfit the facilities described in Subsection 4.3 is $\$ 178$ million. Initially, the facility consists of: 1) a waste handling building, 2) a basic storage yard consisting of one TRUSS building and a cask storage yard designed to accommodate 1000 storage units but equipped only with 100 concrete storage pads, and 3) support or auxiliary buildings (i.e., an administration, maintenance, warehouse, and patrol buildings), security system, etc. A summary of the cost estimates is provided in Table 4.7 .

The capital costs include the direct construction costs and the percentages of construction costs assigned for the functions of design, indirect labor, contingency, and owner's cost for contract management. The general bases used for the capital, operating, and decommissioning costs are presented in Table 4.8 . 


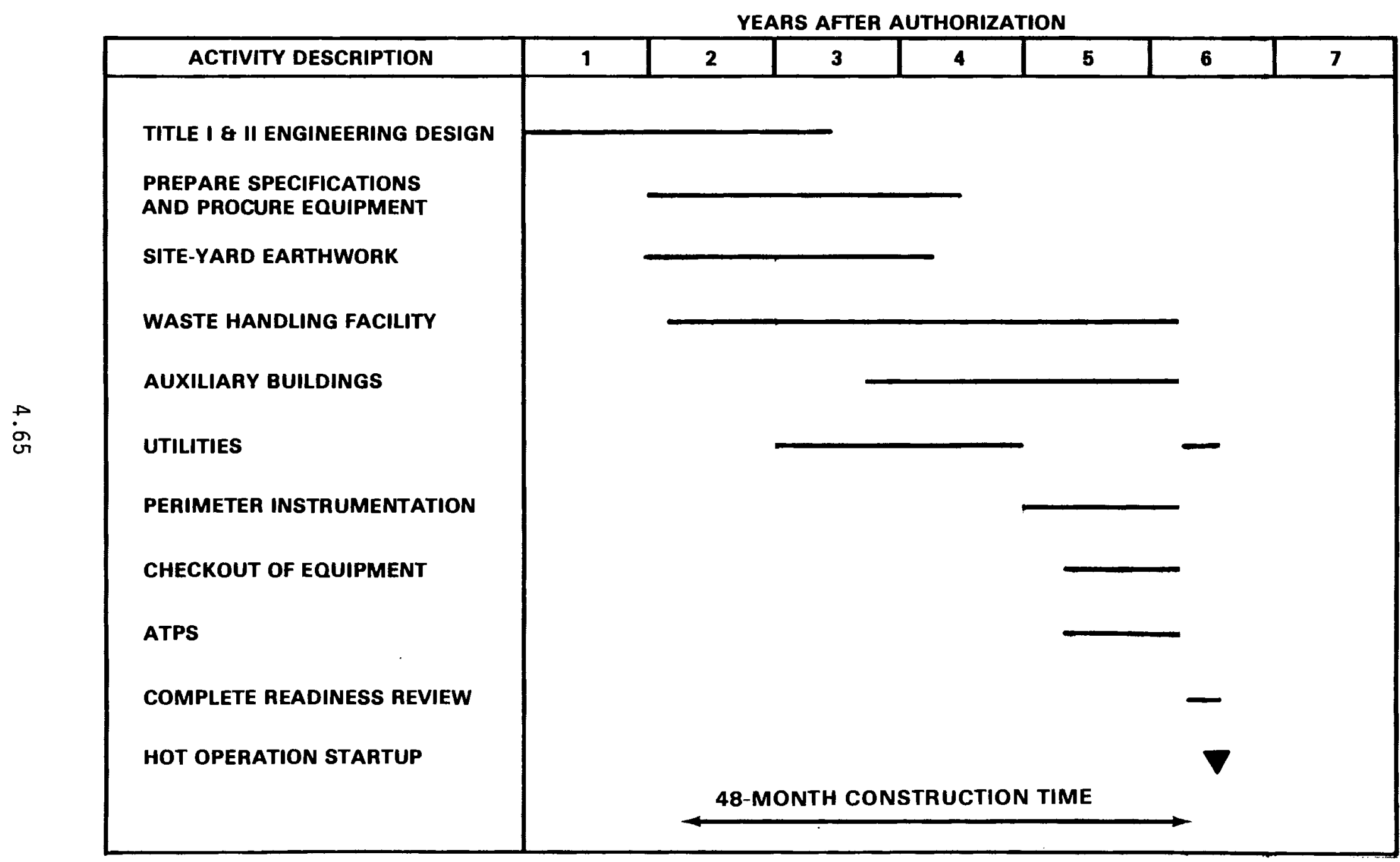

FIGURE 4.21. Postulated MRS/IS Facility Design and Construction Schedule 
TABLE 4.7. Construction Capital Cost Summary (thousands of mid-1982 dollars)

A. (a) Construction

Offsite Development (electrical, roads, railroads, water)

$\$ 7,500$

Land Improvements (railroads, roads, sidewalks)

4,200

Waste Handling Facility

44,200

Cargo Receiving and Shipping

Hot Cell

Radwaste System

Hot Maintenance Shop

Mechanical Electrical Instrument 5,200 System

HVAC and Personnel $\quad 8,500$

Service Facilities (standby generator,

6,000 security buildings)

Storage facilities (warehouse, rail cars)

2,500

Other Facilities

1,850

Waste Handling System

2,450

Area Service Systems (electrical, security, water, radiological waste management, lighting)

32,000

TRUSS Building

2,500

Transporter and Gantry Crane

2,000

Subtotal

$\$ 105,200$

B. Cask Storage Yard (100 pads)

C. Indirect Costs $(12.5 \%$ of $A+B)$

13,200

D. Engineering and Services $(12 \%$ of $A+B+C)$

14,250

E. Contingency $(25 \%$ of $A+B+C+D)$

33,250

F. Owners cost $(7 \%$ of $A+B+C+D+E)$

11,780

Total Cost

(a) Letters refer to categories of cost as listed in Table 4.8. 
TABLE 4.8. Cost Estimating Factors

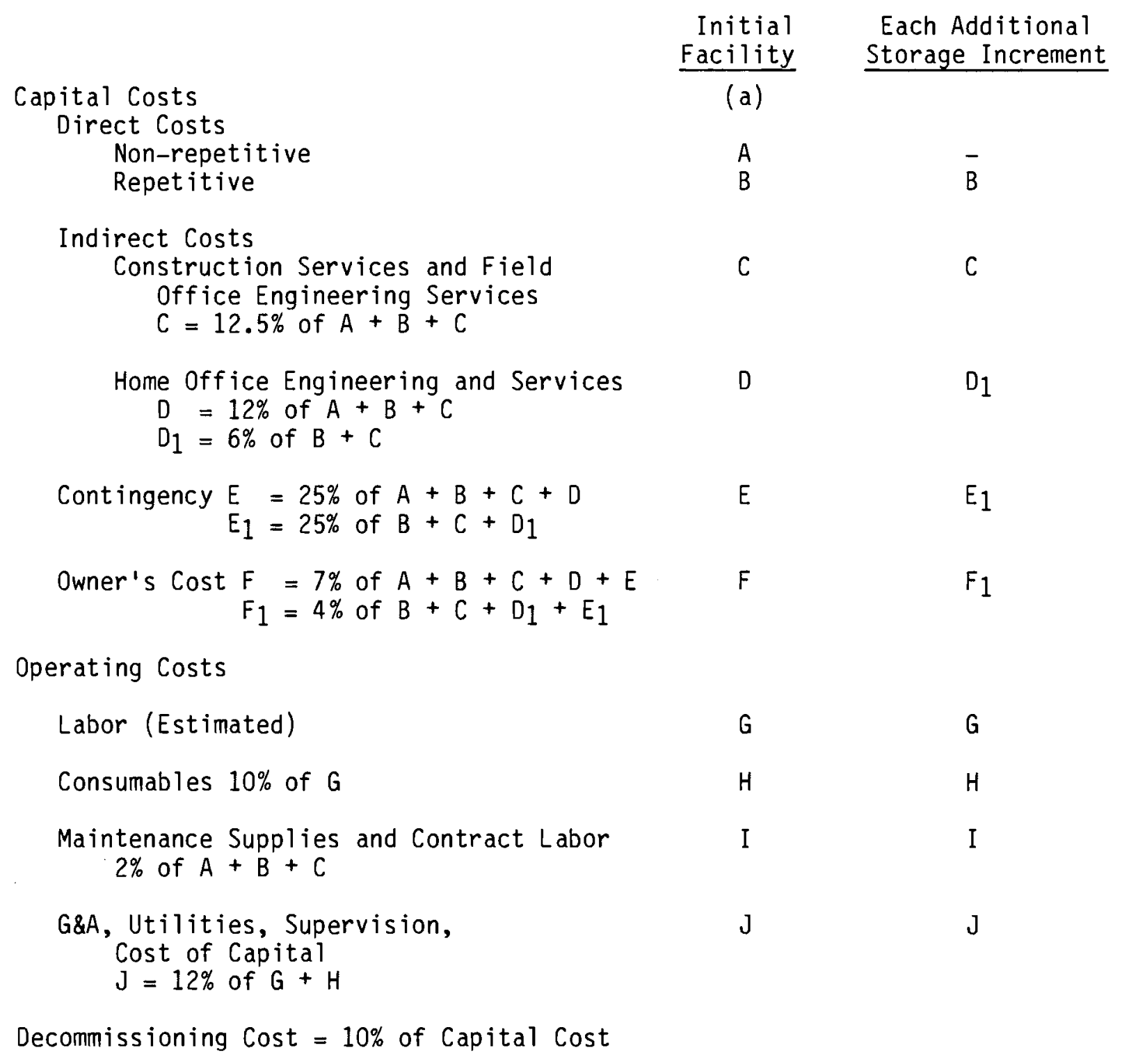

(a) These letter designations are used in Tables 4.7 and 4.14 . 
The estimated costs associated with bringing the utility systems to the site are presented in Table 4.9, assuming the indicated distances are appropriate for connection to existing Hanford systems.

TABLE 4.9. Construction Costs for Utilities

(mil1ions of mid-1982 dollars)

$\begin{array}{lcc} & \frac{\text { Per Mile }}{0.160} & \frac{\text { Total }}{3.83} \\ \begin{array}{l}\text { Water - River Pumps and } \\ \text { 10-in. Pipe (7 miles) }\end{array} & & \\ \text { Electrical - } 115 \mathrm{kVA}, 10 \mathrm{MW} \text { (5 miles) } & 0.087 & 0.44 \\ \text { Roads - 2 Lane, Heavy Duty (5 miles) } & 0.275 & 1.38 \\ \text { Railroad - Single Track (5 miles) } & 0.370 & \frac{1.85}{7.50}\end{array}$

\subsubsection{Cost and Schedule: Reference Metal Storage Casks}

The number of metal casks required to store spent fuel and HLW varies for each scenario. A schedule for the purchase of casks is provided in Table 4.10. The following assumptions are used in developing the data provided in that table:

- Metal cask storage capacities (payload) are:

- 14 HLW waste canisters per cask

- 52 BWR spent fuel assemblies per cask

- 24 PWR spent fuel assemblies per cask

- Casks will be purchased in the year of their actual use.

Each cask purchased, regardless of design payload, is assumed to cost $\$ 700,000$ plus a 25 percent contingency, or $\$ 875,000$. The purchase of casks is assumed to be a capital expenditure.

\subsubsection{Cost and Schedule: Metal Cask Support Pads}

Cask support pads will be constructed as the need arises. Initially the facility will incorporate 100 storage pads on a storage field designed to accommodate 1000 storage units (casks). A schedule for adding additional storage pads and additional storage fields is provided in Table 4.11 . 
TABLE 4.10. Schedule and Costs for Annual Purchases of Metal Storage Casks

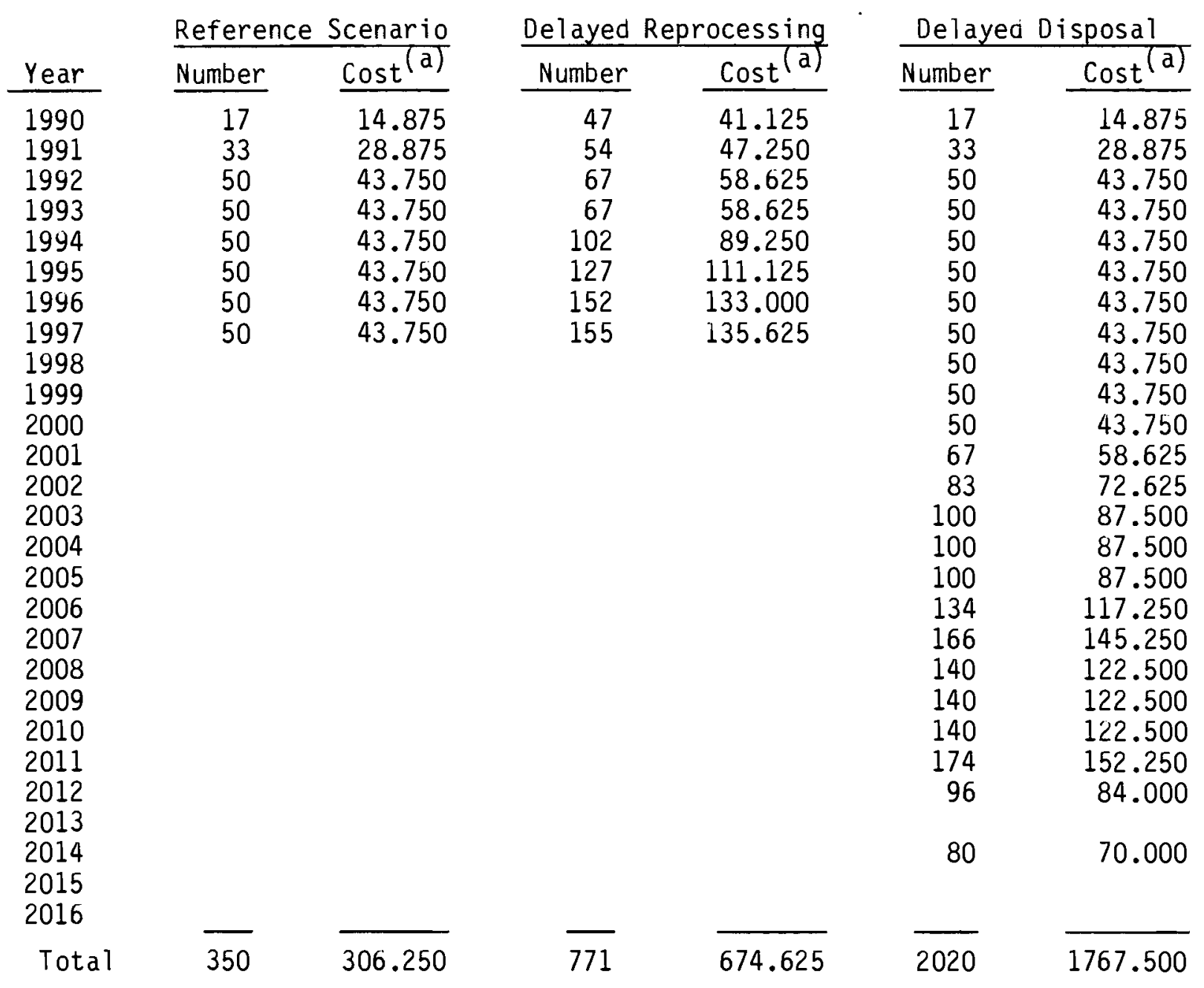

(a) Costs in millions of mid-1982 dollars. 
TABLE 4.11. Schedule and Costs for Annual Construction of Storage Pads and Storage Fields for Metal Casks

\begin{tabular}{|c|c|c|c|c|c|c|c|c|c|c|c|c|}
\hline \multirow[b]{2}{*}{ Year } & \multicolumn{4}{|c|}{ Reference Scenario } & \multicolumn{4}{|c|}{ Delayed Reprocessing } & \multicolumn{4}{|c|}{ Delayed Disposal } \\
\hline & $\begin{array}{r}\overline{\text { No. }} \\
\text { Pads } \\
\end{array}$ & Cost $(a)$ & $\begin{array}{l}\text { No. } \\
\text { Fields }\end{array}$ & Cost ${ }^{(a)}$ & $\begin{array}{r}\text { No. } \\
\text { Pads } \\
\end{array}$ & $\operatorname{Cost}^{(a)}$ & $\begin{array}{l}\text { No. } \\
\text { Fields } \\
\end{array}$ & Cost $(a)$ & $\begin{array}{r}\text { No. } \\
\text { Pads } \\
\end{array}$ & $\operatorname{Cost}^{(a)}$ & $\begin{array}{r}\text { No. } \\
\text { Fields } \\
\end{array}$ & $\operatorname{Cos} t^{(a)}$ \\
\hline $\begin{array}{l}1985 \\
1986 \\
1987 \\
1988 \\
1989 \\
1990\end{array}$ & 100 & 0.2 & 1 & 0.3 & 100 & 0.2 & 1 & 0.3 & 100 & 0.2 & 1 & 0.3 \\
\hline $\begin{array}{l}1991 \\
1992\end{array}$ & & & & & & & & & & & & \\
\hline $\begin{array}{l}1992 \\
1993\end{array}$ & 100 & 0.2 & & & 100 & 0.2 & & & 100 & 0.2 & & \\
\hline 1994 & 100 & 0.2 & & & 100 & 0.2 & & & 100 & 0.2 & & \\
\hline 1995 & & & & & 200 & 0.4 & & & & & & \\
\hline $\begin{array}{l}1996 \\
1997\end{array}$ & 100 & 0.2 & & & 80 & 0.16 & & & 100 & 0.2 & & \\
\hline $\begin{array}{l}1998 \\
1999\end{array}$ & & & & & & & & & 100 & 0.2 & & \\
\hline 2000 & & & & & & & & & 100 & 0.2 & & \\
\hline 2001 & & ' & & & & & & & 100 & 0.2 & & \\
\hline 2002 & & & & & & & & & 100 & 0.2 & & \\
\hline 2003 & & & & & & & & & 100 & 0.2 & 1 & 0.3 \\
\hline 2004 & & & & & & & & & 100 & 0.2 & & \\
\hline 2005 & & & & & & & & & 100 & 0.2 & & \\
\hline 2006 & & & & & & & & & 200 & 0.4 & & \\
\hline 2007 & & & & & & & & & 200 & 0.4 & & \\
\hline 2008 & & & & & & & & & 100 & 0.2 & & \\
\hline 2009 & & & & & & & & & 100 & 0.2 & & \\
\hline 2010 & & & & & & & & & 200 & 0.4 & 1 & 0.3 \\
\hline 2011 & & & & & & 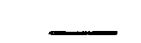 & - & - & 50 & 0.1 & & \\
\hline Total & 400 & 0.8 & 1 & 0.3 & 780 & 1.56 & 1 & 0.3 & 2020 & 4.04 & 3 & 0.9 \\
\hline
\end{tabular}

(a) Costs in millions of mid-1982 dollars.

The cost associated with each are assumed to be $\$ 2,000$ per storage pad and $\$ 300,000$ per storage field including indirect costs. It is assumed that storage pads and new storage fields are added the year prior to the need. Within reason, basic modules (additions) are assumed to be in multiples of 100 storage pads. The costs associated with construction of additional storage pads and storage areas are assumed to be a capital expenditure. 


\subsubsection{Cost and Schedule: Concrete Casks}

Concrete storage casks will be used to store RHTRU for both the Reference scenario and the Delayed Disposal scenario. The following assumptions are used to delineate a schedule for the purchase of concrete storage casks.

- Concrete cask storage capacities are:

- 12 RHTRU drums/cask

- 3 RHTRU canisters/cask

- Storage casks are reused if available.

- Storage casks are purchased in the year of their need or use.

A schedule for the purchase of concrete storage casks for both the Reference scenario and the Delayed Disposal scenario is presented in Table 4.12. The cost of each concrete cask was assumed to be $\$ 25,000$. The costs associated with purchasing concrete storage casks are assumed to be capital expenditures.

\subsubsection{Cost and Schedule: Concrete Cask Support Pads}

Concrete cask support pads will be constructed as the need arises. The pads will be constructed in modules of 500 in storage fields designed to accommodate 1000 storage units. The first storage pads and storage field will be constructed in 1988. Subsequent storage pad modules and additional storage fields will be constructed the year prior to their need. The schedule of construction storage pads and fields for concrete casks is presented in Table 4.13. The estimated cost associated with construction of each storage pad is $\$ 2,000$ and with each storage field is $\$ 300,000$ including indirect costs. The costs resulting from adding storage pads and storage fields are assumed to be capital expenditures.

\subsubsection{TRUSS Buildings}

For the Delayed Disposal scenario, additional TRUSS buildings will be constructed in the years 2003, 2006, 2009 and 2013 to store the projected quantities of CHTRU. Each additional storage unit (TRUSS building) is assumed to cost $\$ 2.5$ million. The cost associated with constructing each additional TRUSS building is assumed to be a capital expenditure. 
TABLE 4.12. Schedule and Costs for Annual Purchases of Concrete Storage Casks

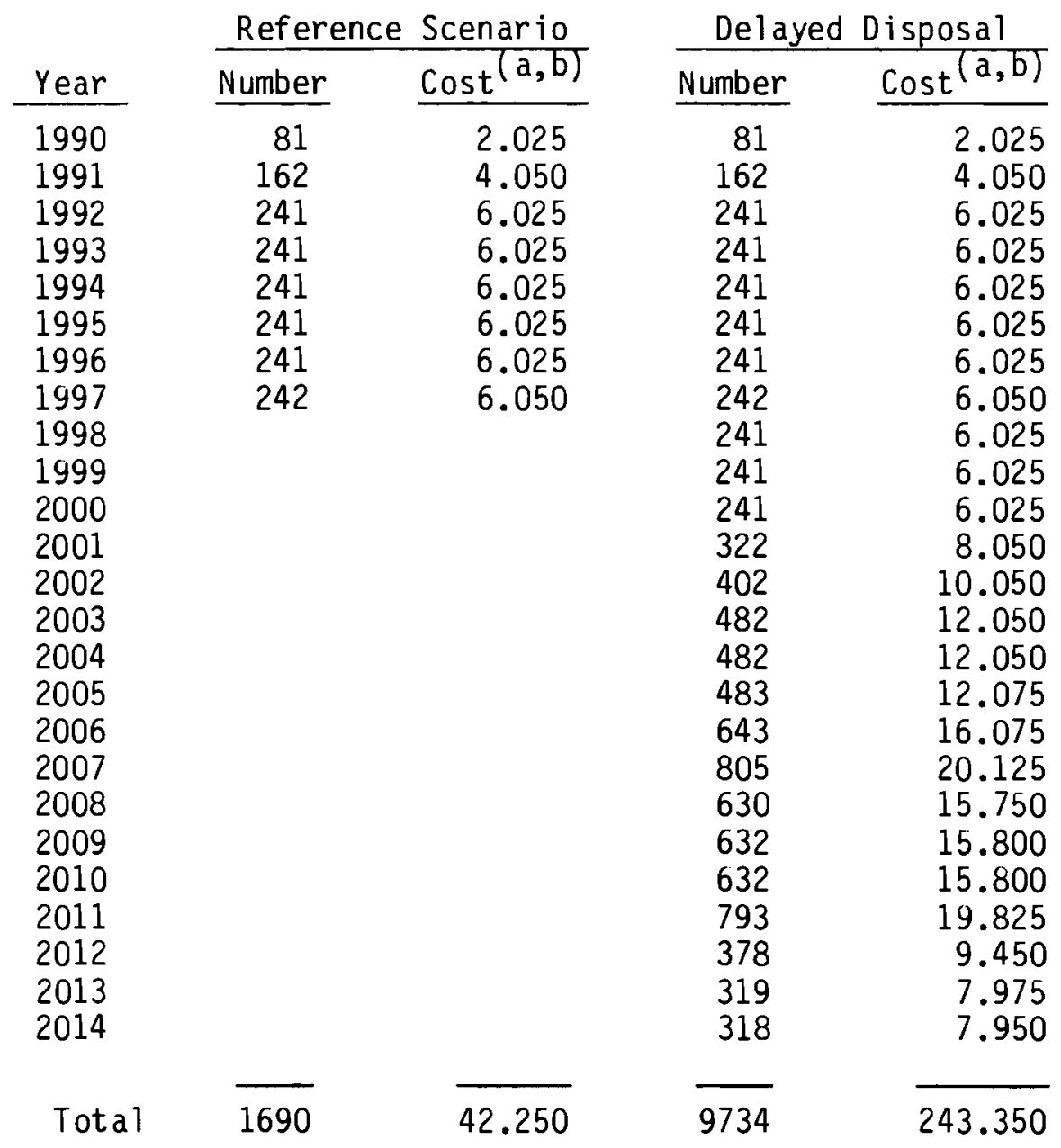

(a) Costs in millions of mid-1982 dollars.

(b) The number of significant figures is for computational accuracy and does not imply precision to the nearest $\$ 1000$. 
TABLE 4.13. Schedule and Costs for Annual Construction of Storage Pads and Storage Fields for Concrete Casks

\begin{tabular}{|c|c|c|c|c|c|c|c|c|}
\hline \multirow[b]{2}{*}{ Year } & \multicolumn{4}{|c|}{ Reference Scenario } & \multicolumn{4}{|c|}{ Delayed Disposal } \\
\hline & $\begin{array}{l}\text { No. } \\
\text { Pads } \\
\end{array}$ & $\operatorname{Cost}^{(a)}$ & $\begin{array}{c}\text { No. } \\
\text { Fields }\end{array}$ & $\operatorname{Cost}(a)$ & $\begin{array}{r}\text { No. } \\
\text { Pads } \\
\end{array}$ & Cost $(a)$ & $\begin{array}{c}\text { No. } \\
\text { Fieids } \\
\end{array}$ & $\operatorname{Cost}(a)$ \\
\hline $\begin{array}{l}1988 \\
1989 \\
1990 \\
1991\end{array}$ & 500 & 1.0 & 1 & 0.3 & 500 & 1.0 & 1 & 0.3 \\
\hline $\begin{array}{l}1992 \\
1993\end{array}$ & 300 & 1.0 & 1 & 0.3 & 500 & 1.0 & 1 & 0.3 \\
\hline $\begin{array}{l}1994 \\
1995\end{array}$ & 500 & 1.0 & & & 500 & 1.0 & & \\
\hline $\begin{array}{l}1996 \\
1997\end{array}$ & 190 & 0.38 & & & 500 & 1.0 & 1 & 0.3 \\
\hline $\begin{array}{l}1998 \\
1999\end{array}$ & & & & & 500 & 1.0 & & \\
\hline $\begin{array}{l}2000 \\
2001\end{array}$ & & & & & $\begin{array}{l}500 \\
500\end{array}$ & $\begin{array}{l}1.0 \\
1.0\end{array}$ & 1 & 0.3 \\
\hline $\begin{array}{l}2002 \\
2003\end{array}$ & & & & & $\begin{array}{l}500 \\
500\end{array}$ & $\begin{array}{l}1.0 \\
1.0\end{array}$ & 1 & 0.3 \\
\hline 2004 & & & & & 500 & 1.0 & 1 & 0.3 \\
\hline $\begin{array}{l}2005 \\
2006\end{array}$ & & & & & $\begin{array}{r}500 \\
1000\end{array}$ & $\begin{array}{l}1.0 \\
2.0\end{array}$ & 1 & $0 ?$ \\
\hline 2007 & & & & & 500 & $\begin{array}{l}1.0 \\
1.0\end{array}$ & 1 & U.J \\
\hline 2008 & & & & & 500 & 1.0 & 1 & 0.3 \\
\hline $\begin{array}{l}2009 \\
2010\end{array}$ & & & & & 500 & 1.0 & 1 & 0.3 \\
\hline 2011 & & & & & 500 & 1.0 & & \\
\hline 2012 & & & & & 234 & 0.47 & 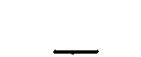 & \\
\hline Total & 1690 & 3.38 & 2 & 0.6 & 9734 & 19.47 & 10 & 3.0 \\
\hline
\end{tabular}

(a) Costs in millions of mid-1982 dollars. 


\subsubsection{Annual Operating Expense}

The annual cost associated with operating the Reference facility (i.e., labor and materials) is estimated to be $\$ 11.53$ million. A staff of approximately 138 is required to operate the MRS/IS facility and approximately 62 support personnel are needed to administer and safeguard the facility. A summary of the annual operating expense is presented in Table 4.14.

For the Reference and the Delayed Reprocessing scenarios, it is assumed the co-located geologic repository would come on- 1 ine in 1998. Since all of the MRS/IS facility except the interim storage areas would be utilized to service the underground repository, it has also been assumed that most of the operating costs after that date would be to the repository account. This would include the operating expense of removing the various wastes stored in the different interim storage areas and transferring them to the underground repository. As shown in Appendices $B$ and $C$, this would require several years to accomplish.

A similar approach is assumed for the Delayed Disposal scenario. Although, the first repository comes on- line in 2008, this MRS/IS facility would function and receive wastes until after the second and third repostitories open in 2012 and 2015, respectively. Assuming the first

TABLE 4.14. Yearly Operating Costs for the MRS/IS Facility (millions of mid-1982 dollars)
G. (a) Labor
H. Consumables ( $10 \%$ of $G) \quad 0.74$
I. Maintenance $(2 \%$ of $A+B+C$ of Table 4.7) 2.37
J. G\&A, Utilities, Supervision, Cost of Capital $(12 \%$ of $G+H)$

(a) Letters refer to categories of cost as listed in Table 4.8. 
repository would be the one co-located with this MRS/IS facility, then the operating costs of the original facility would be assumed by the repository in 2016. Between 2008 and 2016 the cost of operating the MRS/IS facility would be shared with the repository.

\subsubsection{Transportation Costs}

The bases for assigning transportation costs are described in Subsection 3.5, with additional details presented in Appendix C. A summary of the transportation cost for each scenario is provided in Table 4.15. The transportation cost is assumed to be an operational expense. Only those incremental offsite transportation costs associated with the MRS/IS facility that are in addition to the transportation costs normally required in the waste management system without an MRS/IS facility are included in the MRS/IS facility life cycle costs.

\subsubsection{Drywell Storage}

An alternative to storing spent fuel and $\mathrm{HLW}$ in a metal storage cask on the surface is a drywell imbedded in the soil. In this case, the RHTRU canisters and drums continue to be stored in the surface-mounted concrete casks, as before.

For the drywell storage system it is assumed that minimum changes would be required to either the design or the operation of the WHF. Since the hot cells within the building has an adequately-sized, semi-automatic system for canistering of failed fuel or HLW, no capacity increases are needed for canistering of all fuels. The other operations such as fuel unloading or loading require essentially the same systems as for the reference cask storage.

Other supporting buildings, services and utilities for drywell storage are the same as for the reference metal cask. The cost of the transporter for the drywell system is essentially the same as the cost of the trailer and gantry for the cask system.

The cost of constructing a drywell is estimated to be $\$ 18,000$ each including indirect costs. The drywells are arranged in fields of 1000 wells each and each field is estimated to cost $\$ 300,000$ to prepare. 
TABLE 4.15. Annual Transportation Costs for Each Scenario
(millions of mid-1982 dollars) (a) $\frac{\text { Reference Scenario }}{\text { Total MRS }} \frac{\text { Delayed Reprocessing }}{\text { Total MRS }} \frac{\text { Delayed Disposal }}{\text { Total }}$

\begin{tabular}{|c|c|c|c|c|c|c|}
\hline Year & System & Incremental & System & Incremental & System & Incremental \\
\hline 1990 & 17.675 & 0 & 40.097 & 32.536 & 60.778 & 0 \\
\hline 1991 & 34.794 & 0 & 45.893 & 43.934 & 36.136 & 0 \\
\hline 1992 & 51.918 & 0 & 56.140 & 45.626 & 51.918 & 0 \\
\hline 1993 & 51.918 & 0 & 58.091 & 45.933 & 51.918 & 0 \\
\hline 1994 & 51.918 & 0 & 87.039 & 70.595 & 51.918 & 0 \\
\hline 1995 & 51.918 & 0 & 108.416 & 88.206 & 51.918 & 0 \\
\hline 1996 & 51.918 & 0 & 130.202 & 105.797 & 51.918 & 0 \\
\hline 1997 & 51.918 & 0 & 130.340 & 105.783 & 51.918 & 0 \\
\hline 1998 & & 0 & & & 51.918 & 0 \\
\hline 1999 & & 0 & & & 51.918 & 0 \\
\hline 2000 & & 0 & & & 51.918 & 0 \\
\hline 2001 & & 0 & & & 69.232 & 0 \\
\hline 2002 & & 0 & & & 86.445 & 0 \\
\hline 2003 & & 0 & & & 102.859 & 0 \\
\hline 2004 & & 0 & & & 102.859 & 0 \\
\hline 2005 & & 0 & & & 102.859 & 0 \\
\hline 2006 & & 0 & & & 138.356 & 0 \\
\hline 2007 & & 0 & & & 172.841 & 0 \\
\hline 2008 & & 0 & & & 141.166 & 0 \\
\hline 2009 & & 0 & & & 141.166 & 0 \\
\hline 2010 & & 0 & & & 141.166 & 0 \\
\hline 2011 & 21.929 & 0 & & & 175.920 & 0 \\
\hline 2012 & 10.300 & 0 & 54.262 & 54.262 & 92.551 & 0 \\
\hline 2013 & 26.898 & 0 & 42.799 & 42.799 & 45.900 & 0 \\
\hline 2014 & 39.035 & 0 & 76.229 & 76.229 & b7.710 & 0 \\
\hline 2015 & & 0 & 155.783 & 155.783 & 7.300 & 0 \\
\hline 2016 & & 0 & 238.458 & 238.458 & 10.996 & 0 \\
\hline 2017 & & 0 & 88.851 & 88.851 & & 0 \\
\hline Total & 462.139 & 0 & 1312.600 & 1193.139 & 2163.503 & 0 \\
\hline
\end{tabular}

(a) The number of significant figures is for computational accuracy and does not imply precision to the nearest $\$ 1000$. 
Fuel placed in a drywell must be sealed within a canister. Each canister will hold 3 BWR or 1 PWR fuel assembly and is estimated to cost $\$ 5500$. The cost of preparing the field and the construction and installation of the drywells are assumed to be capital expenditures. The cost of the canisters is assumed to be an operating expense.

A schedule for the construction of storage field and drywells is given in Table 4.16, together with the annual capital expenditures for that construction and installation work for the three fuel cycle scenarios.

\subsubsection{Decommissioning Costs}

With the exception of the storage casks and storage fields, all of the MRS/IS facilities become the surface facilities for the co-located repository when repository operations are begun. Therefore, the cost of decommissioning the surface facilities (except for casks and storage fields), which is estimated to be about 10 percent of the capital cost of these facilities or about $\$ 18$ million, is not chargeable to the MRS/IS system but is charged to the repository system when the repository is closed. It is anticipated that the costs of decontaminating and removing the casks, support pads and storage fields will be paid from funds recovered when the decontaminated metal casks are sold for salvage. As a result, no net costs are assigned to the MRS/IS facility co-located with a repository for decommissioning.

\subsection{LIFE CYCLE COSTS}

To provide compatibility with other studies of spent fuel and waste disposal, life cycle costs are evaluated for the Reference, Delayed Reprocessing, and Delayed Disposal scenarios for the MRS/IS facility co-located with a repository. All costs are presented in terms of constant value, mid-1982 dollars (no escalation or inflation). The bases for costs are provided in Subsection 4.4. In addition to undiscounted program costs, a present worth program cost using a discount factor of 2 percent is included. 
TABLE 4.16. Schedule and Costs for Annual Construction of Drywells and Drywell Fields

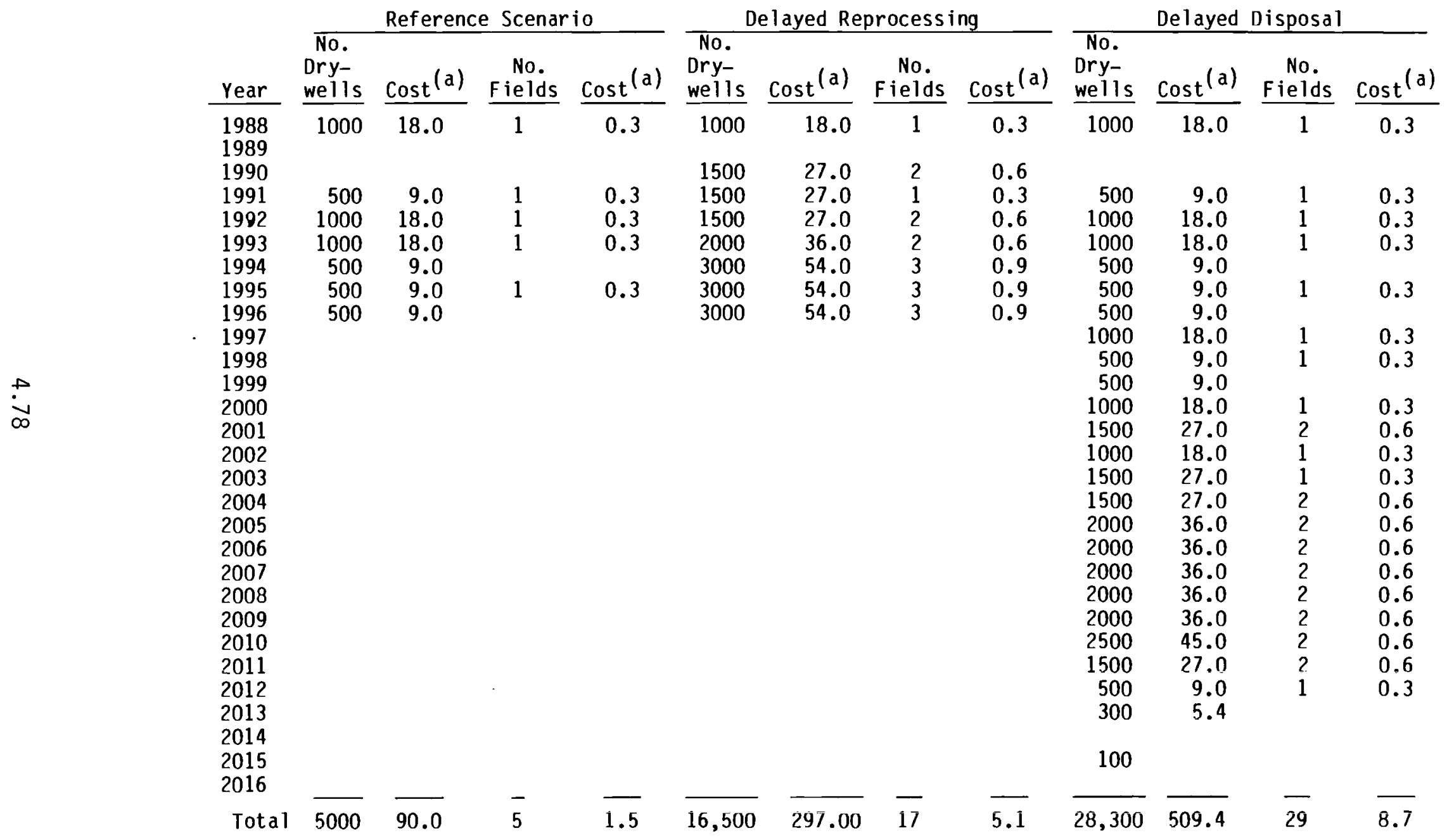

(a) Costs in millions of mid-1982 dollars. 


\subsubsection{Reference Scenario Life Cycle Costs}

A summary of the program costs associated with the Reference scenario, using metal storage casks, is presented in Table 4.17. The undiscounted life cycle cost is estimated to $\$ 0.731$ billion. The discounted life cycle cost is estimated to be $\sim \$ 0.578$ billion.

A similar summary for the Reference scenario, using drywells for storage of spent fuel and HLW canisters instead of metal casks, is given in Table 4.18. The undiscounted life cycle cost is estimated to be $\sim \$ 0.518$ billion. The discounted life cycle cost is estimated to be $-\$ 0.412$ billion.

In developing these cost estimates, it is assumed that for any year in which MRS/IS operations occur after the opening of the repository in 1998, the operating costs are divided approximately equally between the MRS/IS facility and the repository. Thus in the years 1998 through 2015, the annual MRS/IS facility operating cost is $\$ 6.0$ million.

Includea in the operating costs for the drywell case are the cost of the canisters in which the spent fuel is encapsulated.

\subsubsection{Delayed Reprocessing Scenario Life Cycle Costs}

A summary of the program costs associated with the Delayed Reprocessing scenario, using metal storage casks, is presented in Table 4.19. The undiscounted life cycle cost is estimated to be $\$ 2.294$ billion. The discounted life cycle cost is estimated to be $\sim \$ 1.592$ billion.

A similar summary for the Delayed Reprocessing scenario, using drywells for storage of spent fuel instead of metal casks, is given in Table 4.20. The undiscounted life cycle cost is estimated to be $\sim \$ 2.013$ billion. The discounted life cycle cost is estimated to be $\sim \$ 1.376$ billion.

As in the Reference scenario, the costs of operations in years following opening of the repository are divided between the MRS/IS facility and the repository for those years in which material was placed in storage or was shipped off-site. Again, the cost of canisters for spent fuel is included in the operating cost for the drywell case. 
TABLE 4.17. MRS/IS Facility Co-located With a Repository--Reference Scenario, Life-Cycle Cash Flows: Cask Storage (millions mid-1982 dollars) (a)

\begin{tabular}{|c|c|c|c|c|c|}
\hline \multirow[b]{2}{*}{ Year } & \multicolumn{2}{|c|}{ Capital Costs } & \multirow[b]{2}{*}{$\begin{array}{l}\text { Operating } \\
\text { Costs } \\
\end{array}$} & \multirow[b]{2}{*}{$\begin{array}{c}\text { Transpert } \\
\text { Costs }\end{array}$} & \multirow[b]{2}{*}{ Total } \\
\hline & $\begin{array}{l}\text { Handling and } \\
\text { Support } \\
\end{array}$ & Storage & & & \\
\hline $\begin{array}{l}1985 \\
1986\end{array}$ & $\begin{array}{r}8.900 \\
26.700\end{array}$ & & & & $\begin{array}{r}8.900 \\
26.700\end{array}$ \\
\hline $\begin{array}{l}1987 \\
1988 \\
1989 \\
1990 \\
1991\end{array}$ & $\begin{array}{l}35.600 \\
44.500 \\
44.500 \\
17.800\end{array}$ & $\begin{array}{r}1.300 \\
16.900 \\
32.925\end{array}$ & $\begin{array}{l}11.530 \\
11.530\end{array}$ & & $\begin{array}{l}35.600 \\
45.800 \\
44.500 \\
46.230 \\
44.455\end{array}$ \\
\hline $\begin{array}{l}1992 \\
1993 \\
1994 \\
1995 \\
1996\end{array}$ & & $\begin{array}{l}50.975 \\
50.075 \\
50.975 \\
49.775 \\
50.355\end{array}$ & $\begin{array}{l}11.530 \\
11.530 \\
11.530 \\
11.530 \\
11.530\end{array}$ & & $\begin{array}{l}62.505 \\
61.605 \\
62.505 \\
61.305 \\
61.885\end{array}$ \\
\hline $\begin{array}{l}1997 \\
1998 \\
1999 \\
2000 \\
2001\end{array}$ & & 49.800 & $\begin{array}{r}11.530 \\
6.000 \\
6.000 \\
6.000 \\
6.000\end{array}$ & & $\begin{array}{r}61.330 \\
6.000 \\
6.000 \\
6.000 \\
6.000\end{array}$ \\
\hline $\begin{array}{l}2002 \\
2003 \\
2004 \\
2005 \\
2006\end{array}$ & & & $\begin{array}{l}6.000 \\
6.000 \\
6.000 \\
6.000 \\
6.000\end{array}$ & & $\begin{array}{l}6.000 \\
0.000 \\
6.000 \\
6.000 \\
6.000\end{array}$ \\
\hline $\begin{array}{l}2007 \\
2008 \\
2009 \\
2010 \\
2011\end{array}$ & & & $\begin{array}{l}6.000 \\
6.000 \\
6.000 \\
6.000 \\
6.000\end{array}$ & & $\begin{array}{l}6.000 \\
6.000 \\
6.000 \\
6.000 \\
6.000\end{array}$ \\
\hline $\begin{array}{l}2012 \\
2013 \\
2014 \\
2015\end{array}$ & & & $\begin{array}{l}6.000 \\
6.000 \\
6.000 \\
6.000\end{array}$ & & $\begin{array}{l}6.000 \\
6.000 \\
6.000 \\
6.000\end{array}$ \\
\hline ed Total $(c)$ & 178.000 & 353.080 & 200.24 & 0.0 & $\begin{array}{l}731.320 \\
578.165\end{array}$ \\
\hline
\end{tabular}

(a) The number of significant figures is for computational accuracy and does not imply precision to the nearest $\$ 1000$.

(b) Transportation costs are incremental to those which would be incurred if no MRS existed.

(c) Discount rate of 2 percent per year. 
TABLE 4.18. MRS/IS Facility Co-located With a Repository--Reference Scenario, Life-Cycle Cash Flows: Drywell Storage (millions mid-1982 dollars) (a)

\begin{tabular}{|c|c|c|c|c|c|}
\hline Year & $\begin{array}{l}\text { Capital } \\
\text { Handling and } \\
\text { Support } \\
\end{array}$ & sts & $\begin{array}{c}\text { Operating } \\
\text { Costs } \\
\end{array}$ & $\begin{array}{l}\text { Transpprt } \\
\text { Costs } \\
\end{array}$ & Total \\
\hline $\begin{array}{l}1985 \\
1986\end{array}$ & $\begin{array}{r}9.000 \\
27.000\end{array}$ & & & & $\begin{array}{r}9.000 \\
27.000\end{array}$ \\
\hline $\begin{array}{l}1987 \\
1988 \\
1989 \\
1990 \\
1991\end{array}$ & $\begin{array}{l}36.000 \\
45.000 \\
45.000 \\
18.000\end{array}$ & $\begin{array}{r}19.600 \\
2.025 \\
13.350\end{array}$ & $\begin{array}{l}11.530 \\
11.530\end{array}$ & & $\begin{array}{l}36.000 \\
64.600 \\
45.000 \\
31.555 \\
24.880\end{array}$ \\
\hline $\begin{array}{l}1992 \\
1993 \\
1994 \\
1945 \\
1996\end{array}$ & & $\begin{array}{l}25.325 \\
74.625 \\
16.025 \\
15.325 \\
15.405\end{array}$ & $\begin{array}{l}11.530 \\
11.530 \\
11.530 \\
11.530 \\
11.530\end{array}$ & & $\begin{array}{l}36.855 \\
36.155 \\
27.555 \\
26.855 \\
26.935\end{array}$ \\
\hline $\begin{array}{l}1997 \\
1998 \\
1999 \\
2000 \\
2001\end{array}$ & & 6.050 & $\begin{array}{r}11.530 \\
6.000 \\
6.000 \\
6.000 \\
6.000\end{array}$ & & $\begin{array}{r}17.580 \\
6.000 \\
6.000 \\
6.000 \\
6.000\end{array}$ \\
\hline $\begin{array}{l}2002 \\
2003 \\
2004 \\
2005 \\
2006\end{array}$ & & & $\begin{array}{l}6.000 \\
6.000 \\
6.000 \\
6.000 \\
6.000\end{array}$ & & $\begin{array}{l}6.000 \\
6.000 \\
6.000 \\
6.000 \\
6.000\end{array}$ \\
\hline $\begin{array}{l}2007 \\
2008 \\
2009 \\
2010 \\
2011\end{array}$ & & & $\begin{array}{l}6.000 \\
6.000 \\
6.000 \\
6.000 \\
6.000\end{array}$ & & $\begin{array}{l}6.000 \\
6.000 \\
6.000 \\
6.000 \\
6.000\end{array}$ \\
\hline $\begin{array}{l}2012 \\
2013 \\
2014 \\
2015\end{array}$ & & & $\begin{array}{l}6.000 \\
6.000 \\
6.000 \\
6.000\end{array}$ & & $\begin{array}{l}6.000 \\
6.000 \\
6.000 \\
6.000\end{array}$ \\
\hline ed $\operatorname{Total}(c)$ & 180.000 & 137.730 & 200.240 & 0.0 & $\begin{array}{l}517.970 \\
412.430\end{array}$ \\
\hline
\end{tabular}

Total
Discounted Total $(c)$

(a) The number of significant figures is for computational accuracy and does not imply precision to the nearest $\$ 1000$.

(b) Transportation costs are incremental to those which would be incurred if no MRS existed.

(c) Discount rate of 2 percent per year. 
TABLE 4.19. MRS/IS Facility Co-located With a Repository--Delayed Reprocessing Scenario, Life-Cycle Cash Flows: Cask Storage (millions mid-1982 dollars)(a)

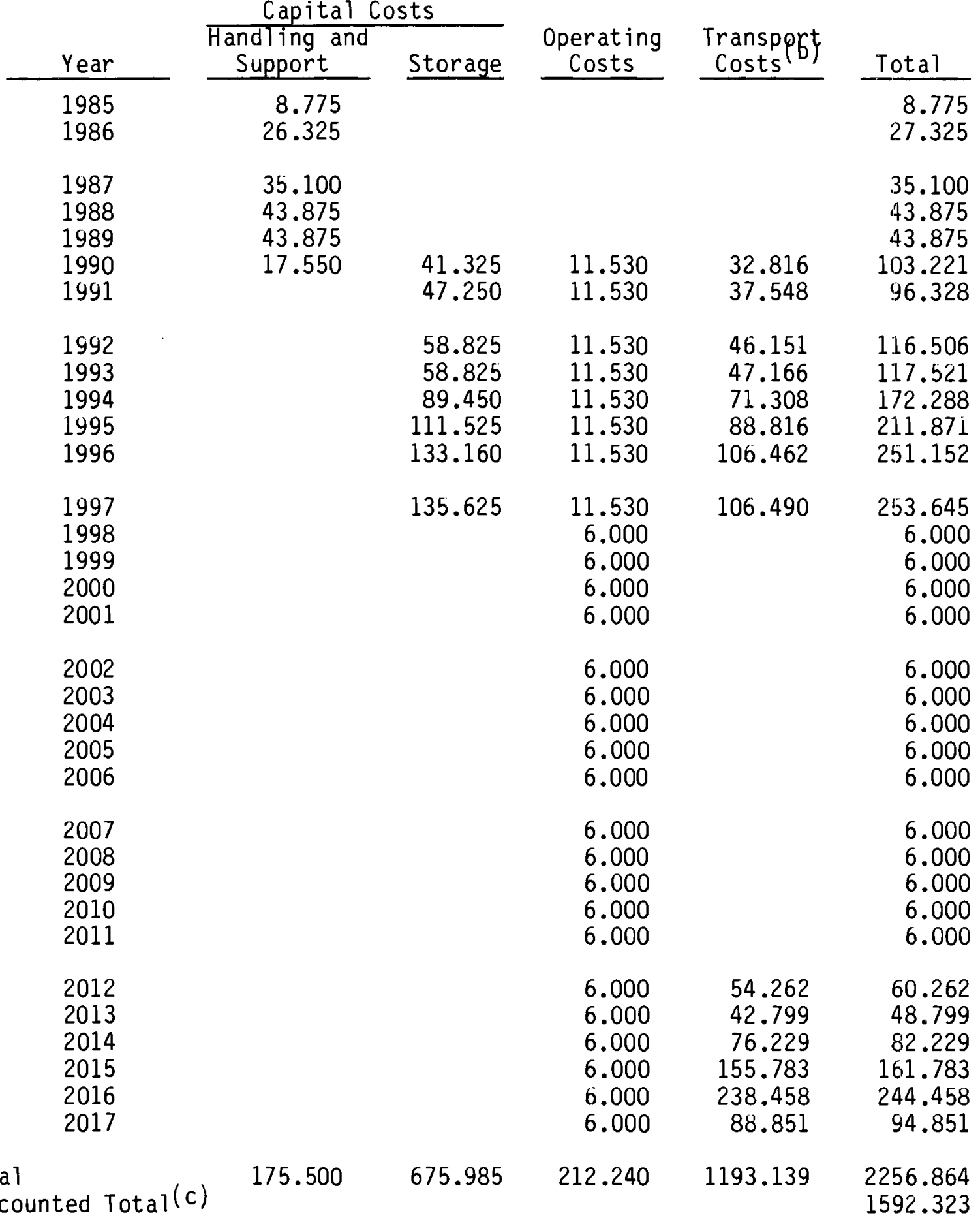

Total

Discounted Total $(c)$

(a) The number of significant figures is for computational accuracy and does not imply precision to the nearest $\$ 1000$.

(b) Transportation costs are incremental to those which would be incurred if no MRS existed.

(c) Discount rate of 2 percent per year. 
TABLE 4.20. MRS/IS Facility Co-located With a Repository--Delayed Reprocessing Scenario, Life-Cycle Cash Flows: Drywell Storage (millions mid-1982 dollars) (a)

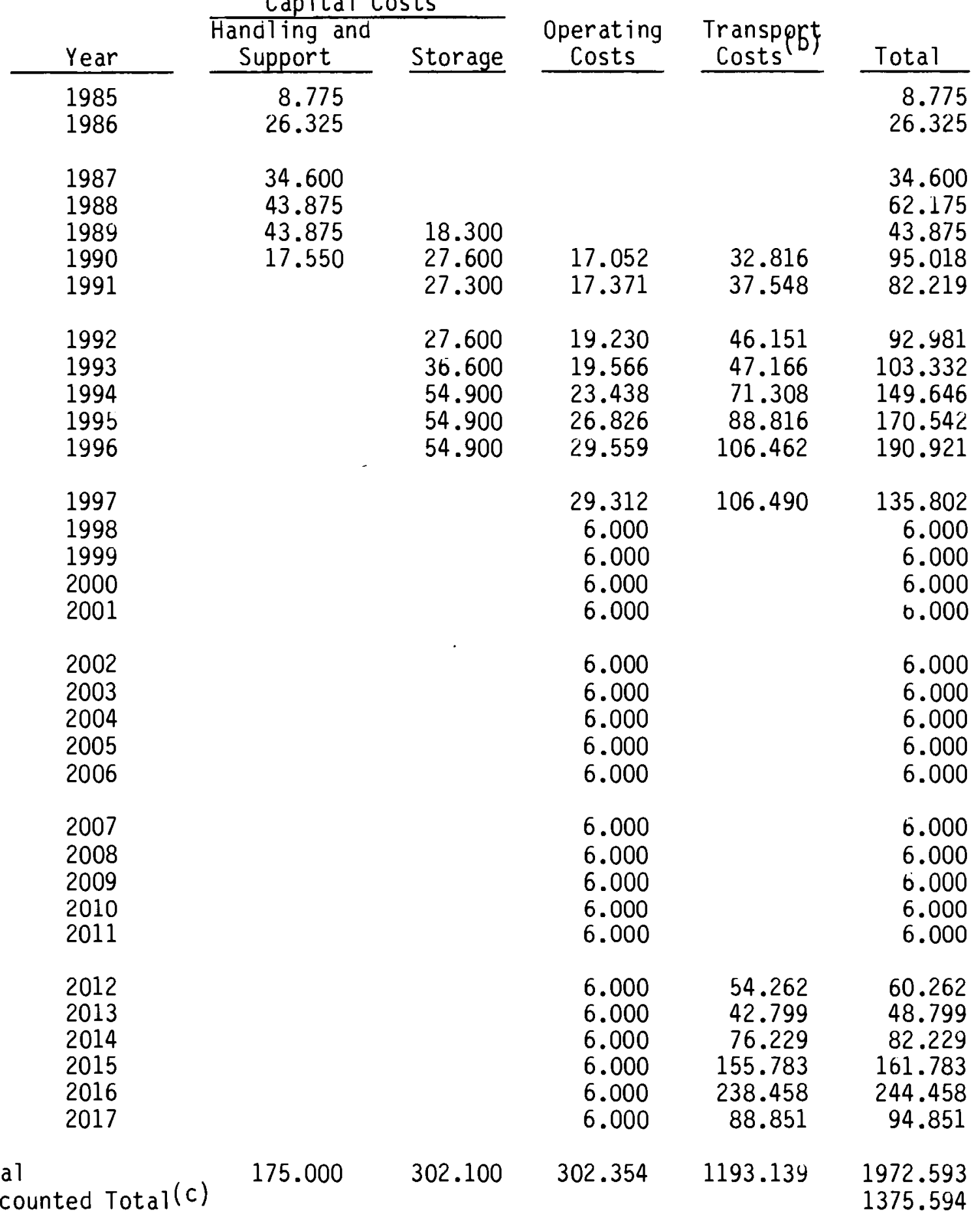

(a) The number of significant figures is for computational accuracy and does not imply precision to the nearest $\$ 1000$.

(b) Transportation costs are incremental to those which would be incurred if no MRS existed.

(c) Discount rate of 2 percent per year. 


\subsubsection{Delayed Disposal Scenario Life Cycle Costs}

A summary of program costs associated with the Delayed Disposal scenario, using metal storage casks, is presented in Table 4.21. The undiscounted 1ife cycle cost is estimated to be $-\$ 2.487$ billion. The discounted life cycle cost is estimated to be $\sim \$ 1.661$ billion.

A similar summary for the Delayed Disposal scenario, using drywells for storage of spent fuel and HLW instead of metal casks, is presented in Table 4.22. The undiscounted life cycle cost is estimated to be $\sim \$ 1.235$ billion. The discounted life cycle cost is estimated to be $-\$ 0.868$ billion. 
TABLE 4.21. MRS/IS Facility Co-1ocated With a Repository--Delayed Reprocessing Scenario, Life-Cycle Cash Flows: Cask Storage (millions mid-1982 dollars)(a)

Capital Costs

\begin{tabular}{|c|c|c|c|c|c|}
\hline Year & $\begin{array}{l}\text { Handling and } \\
\text { Support } \\
\end{array}$ & Storage & $\begin{array}{c}\text { Operating } \\
\text { Costs } \\
\end{array}$ & $\begin{array}{c}\text { Transpprt } \\
\text { Costs }\end{array}$ & Total \\
\hline $\begin{array}{l}1985 \\
1986\end{array}$ & $\begin{array}{r}8.900 \\
26.700\end{array}$ & & & & $\begin{array}{r}8.900 \\
26.700\end{array}$ \\
\hline $\begin{array}{l}1987 \\
1988 \\
1989 \\
1990 \\
1991\end{array}$ & $\begin{array}{l}35.600 \\
44.500 \\
44.500 \\
17.800\end{array}$ & $\begin{array}{r}1.300 \\
16.900 \\
32.925\end{array}$ & $\begin{array}{l}11.530 \\
11.530\end{array}$ & & $\begin{array}{l}35.600 \\
45.800 \\
44.500 \\
46.230 \\
44.455\end{array}$ \\
\hline $\begin{array}{l}1992 \\
1993 \\
1994 \\
1995 \\
1996\end{array}$ & & $\begin{array}{l}50.975 \\
50.075 \\
50.975 \\
49.775 \\
50.975\end{array}$ & $\begin{array}{l}11.530 \\
11.530 \\
11.530 \\
11.530 \\
11.530\end{array}$ & & $\begin{array}{l}62.505 \\
61.605 \\
62.505 \\
61.305 \\
62.505\end{array}$ \\
\hline $\begin{array}{l}1997 \\
1998 \\
1999 \\
2000 \\
2001\end{array}$ & 2.500 & $\begin{array}{l}50.300 \\
50.975 \\
49.975 \\
51.075 \\
67.875\end{array}$ & $\begin{array}{l}11.530 \\
11.530 \\
11.530 \\
11.530 \\
11.530\end{array}$ & & $\begin{array}{l}64.330 \\
62.505 \\
61.505 \\
62.605 \\
79.405\end{array}$ \\
\hline $\begin{array}{l}2002 \\
2003 \\
2004 \\
2005 \\
2006\end{array}$ & 2.500 & $\begin{array}{r}84.175 \\
100.750 \\
101.350 \\
100.775 \\
136.025\end{array}$ & $\begin{array}{l}11.530 \\
11.530 \\
11.530 \\
11.530 \\
11.530\end{array}$ & & $\begin{array}{r}98.205 \\
112.280 \\
112.880 \\
112.305 \\
150.055\end{array}$ \\
\hline $\begin{array}{l}2007 \\
2008 \\
2009 \\
2010 \\
2011\end{array}$ & & $\begin{array}{l}166.775 \\
139.750 \\
139.800 \\
140.800 \\
173.175\end{array}$ & $\begin{array}{r}11.530 \\
6.000 \\
6.000 \\
6.000 \\
6.000\end{array}$ & & $\begin{array}{l}178.305 \\
145.750 \\
145.800 \\
146.800 \\
179.175\end{array}$ \\
\hline $\begin{array}{l}2012 \\
2013 \\
2014 \\
2015 \\
2016\end{array}$ & 2.500 & $\begin{array}{r}93.920 \\
7.975 \\
77.950\end{array}$ & $\begin{array}{l}6.000 \\
6.000 \\
6.000 \\
6.000 \\
6.000\end{array}$ & & $\begin{array}{r}99.920 \\
16.475 \\
83.950 \\
6.000 \\
6.000\end{array}$ \\
\hline ed $\operatorname{Total}(c$ & 188.000 & 2037.320 & 261.540 & 0.0 & $\begin{array}{l}2486.860 \\
1660.739\end{array}$ \\
\hline
\end{tabular}

Total
Discounted Total $(c)$

(a) The number of significant figures is for computational accuracy and does not imply precision to the nearest $\$ 1000$.

(b) Transportation costs are incremental to those which would be incurred if no MRS existed.

(c) Discount rate of 2 percent per year. 
TABLE 4.22. MRS/IS Facility Co-located With a Repository-- Delayed Disposal Scenario, Life-Cycle Cash Flows: Drywell Storage (millions mid-1982 dollars)(a)

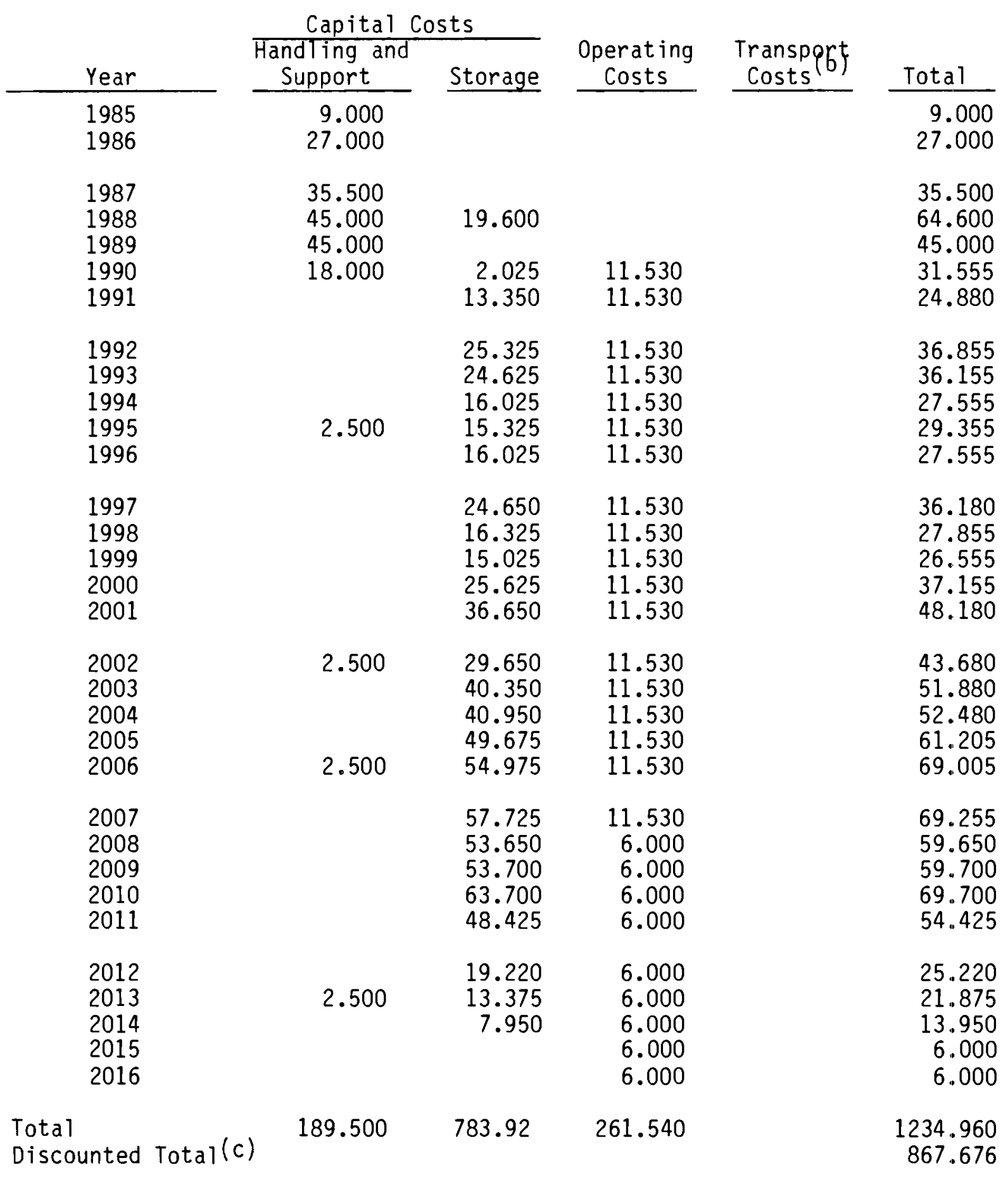

(a) The number of significant figures is for computational accuracy and does not imply precision to the nearest $\$ 1000$.

(b) Transportation costs are incremental to those which would be incurred if no MRS existed.

(c) Discount rate of 2 percent per year. 


\subsection{RELATION TO OTHER FACILITIES}

The monitored retrievable storage/interim storage (MRS/IS) facility co-located with a geologic repository, as one part of the overall nuclear fuel cycle system, has interfaces with several other parts of the system, such as the nuclear power stations, the reprocessing plants, and the geologic repositories. It also has a number of interfaces with the support systems and services already present in the vicinity of the site. These interfaces are discussed in this section.

\subsection{REACTOR POWER STATIONS}

As presently conceived, the MRS/IS facility could receive spent fuel from the reactor stations as necessary for the stations to maintain the ir full core reserve storage capacity. This fuel would be stored until either a reprocessing plant is operating, at which time the fuel would be shipped to the reprocessor, or, if the operation of reprocessing plants is delayed until after a geologic repository is available, some or all of the fuel might be emplaced in the repository without reprocessing. In any event, the principal interface between the MRS/IS facility and the reactor stations is the transportation link by which the spent fuel is transported from the reactors to the MRS/IS facility. Thus, it is essential that the facility is capable of receiving, unloading, loading, and decontaminating any of the present generation of spent fuel shipping casks.

\subsection{REPROCESSING PLANTS}

The interface between the MRS/IS facility and the reprocessing plant is also the transportation link whereby spent fuel is shipped from storage to the reprocessor, and solidified high-level waste (HLW) and transuranic (TRU) waste from the reprocessing operation are shipped to the MRS/IS facility for storage pending availability of a geologic repository. Some additional receiving, unloading, and decontamination capability is necessary to accommodate the TRU waste packages. 


\subsection{GEOLOGIC REPOSITORIES}

The reference MRS/IS facility for this study is located near the planned location of a geologic repository. In most respects, the reference MRS/IS facility is equivalent to the surface facilities that would nomally be required to support the geologic repository. The radioactive waste is received, unloaded, examined, decontaminated and provided with additional packaging if necessary, and transported to the storage location. The principal differences between placing the waste into the MRS/IS facility or into a repository are in the types of additional packaging that might be required and in the methods of transporting the wastes to the storage location. Only the actual storage containers' storage fields are left unused when the MRS/IS facility is converted into the receiving and handling facility for the repository. Transport of wastes from the handling facility to the repository shaft would be accomplished using essentially the same equipment as is used for the MRS/IS facility.

The unused storage capacity of the MRS/IS facility provides a convenient surge storage for the repository, when and if needed. A list of the main items and functions common to the MRS/IS facility and the repository that would serve to reduce the capital costs for the paired system is given in Table 5.1.

\subsection{LOCAL SITE SUPPORT SYSTEMS}

The selection of the Hanford Site as the location of the MRS/IS facility co-located with a repository makes possible the utilization of many support services already available on the Site. These services are discussed briefly in this subsection.

\subsubsection{Transportation Services}

The Hanford Site is served by an existing network of rail lines extending to nearly all parts of the Site. The Hanford rail network is connected directly to the principal railroads operating in the Pacific Northwest, with connections to other major rail roads in the U.S. 
TABLE 5.1. Items and Functions Shared or Used by Both MRS/IS Facility and the Repository

Capital

Permits and Licenses

Design and Engineering

Site Preparation

Facilities

- Administration

- Receiving/Surge Storage

- Packaging/Transfers

- Support

Engineered Equipment

- Cranes

- Packaging/Transfers

- Decont amination

- Ventilation and Containment

- Spare Parts

Operations

Inspection and $Q A$

Support

Utilities

Operational Personnel

Security Personne 1

Maintenance Personnel

Decontamination and Decommissioning

Disposal

Rehabilitation 
Extension of the existing Hanford rail networks to the MRS/IS/Repository site can be accomplished relatively easily, with the length of new track likely to be in the vicinity of 5 miles or less.

The Hanford Site is also served by a network of onsite highways, with connections to major state and interstate highways. Extensions of the existing highway network to the MRS/IS/Repository site can also be accomplished relatively easily, with the length of roadway to be added likely to be in the vicinity of 5 miles or less.

The Hanford Site is also served by river barge on the Columbia River, thus making the shipment of large, heavy items relatively easy.

\subsubsection{Essential Services}

The Hanford Site is served by a large network of electric power transmission lines owned and operated by the Bonneville Power Administration. These lines interconnect the principal electricity generating stations in the Pacific Northwest and provide an assured source of electrical energy to the facilities on the Hanford Site. Extension of the existing Hanford distribution system to the MRS/IS/Repository site can be accomplished readily.

Water for use at the site would be pumped from the Columbia River at an existing pumping station by the installation of new pumps and delivered to the site through a new delivery line. Alternatively, if the demand for water is not too great, wells could be drilled into the underlying aquifer and the necessary water pumped to the surface. In any event, ample water supplies can be made available.

Sludges from the sanitary waste disposal system and from process waste evaporation ponds would be disposed of at the existing Hanford sludge disposal facilities.

In view of the close proximity of the MRS/IS/Repository to existing Hanford waste treatment facilities, and since the quantities of radioactive waste generated within the MRS/IS/Repository complex are expected to be quite small, extensive systems for treatment of radioative wastes should not be required at the complex. 
The Hanford Site is served by an existing telephone system which is connected into the national telephone network. Additional communications are available through the plant radio network, under the control of the plant security forces.

Security for the Hanford Site and for government-owned facilities on the Site is provided by the Hanford Patrol organization. Rapid response to any situations requiring such a response is made possible by a closely-integrated communications system, a fleet of emergency response vehicles, and a large force of well-trained personnel. It is expected that security at the MRS/IS/Repository site would be provided by the Hanford Patrol organization.

\subsubsection{Other Support Services}

The existing central stores, employee transport, contaminated laundry service, central heavy equipment and vehicle maintenance, and central computing services already in operation on the Hanford Site are available as needed by the MRS/IS/Repository complex. 


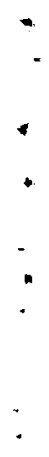




\subsection{RESULTS AND RECOMMENDATIONS}

The monitored retrievable storage/interim storage (MRS/IS) facility design which is evaluated in this study is derived from a design developed by Kaiser Engineers for the Basalt Waste Isolation Program. The design by Kaiser Engineers encompassed all of the facilities required on the earth's surface to service the deep geologic repository. For this study, those facilities not required to serve MRS/IS functions are eliminated, and the storage fields and transuranic (TRU) warehouse are added. The resulting reference MRS/IS facility design has an estimated capital cost of $\$ 178$ million in mid-1982 dollars. Included in this base cost are: the waste handling facility (WHF); the initial storage field for metal casks with 100 storage pads; the initial warehouse building for storing contact-handled TRU (CHTRU) wastes; and the necessary support facilities as described in Subsection 4.3 of this report. The metal casks or drywells used for storing spent fuel and high-level wastes (HLW) and the concrete casks used for storing remote-handled TRU (RHTRU) wastes are purchased as required throughout the operational life of the facility.

The results of the analyses for the three principal scenarios are presented and discussed in Subsection 6.1. The advantages and disadvantages of co-locating an MRS/IS facility with a repository are discussed in Subsection 6.2, and recommendations derived from consideration of the analyses results and the advantages and disadvantages are presented in Subsection 6.3 .

\subsection{RESULTS OF STUDY ANALYSES}

The components of the life cycle cost (undiscounted) for each of the three scenarios and for two storage devices (metal casks, drywells) are presented in Table 6.1 , together with the percentages of total cost that each component represents. These percentages, illustrated in Figure 6.1 , indicate the relative importance of each cost component, and suggest which of the cost components might be most useful to examine in search of cost reductions. 
TABLE 6.1. Components of Life Cycle Costs, Percentages and Totals (millions of mid-1982 dollars, undiscounted)

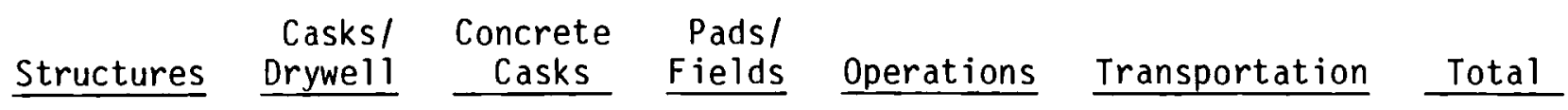

\section{Reference}

Scenario

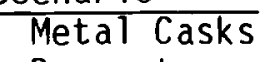

Percent

\section{$178.0 \quad 306.250$}

42.25

4.58

200.24

Drywells

Percent

24.3

41.9

5.8

0.6

27.4

180.0

90.0

34.8

42.25

8.2

4.98

200.24

$\begin{array}{ll}1.0 & 38.7\end{array}$

731.32

100.0

517.97

100.0

Delayed

in

Reprocessing

Metal Casks

Percent

175.5

$-$

1.36

212.240

1193.139

2256.864

$7.8 \quad 29.9$

0.1

9.4

52.9

100.0

Drywells

$175.0 \quad 297.000$

Percent

8.7

14.8

$--$

$5.1 \quad 302.354$

$0.3 \quad 15.0$

1233.612
61.3

2013.066

Delayed

$\frac{\text { Disposal }}{\text { Metal Casks }}$

Percent

$\begin{array}{rr}188.0 & 1767.5 \\ 7.6 & 71.1 \\ & \\ 189.5 & 509.4 \\ 15.3 & 41.2\end{array}$

243.35

9.8

26.91

261.54

Drywells

Percent

15.3

41.2

243.35

19.7

1.1

10.5

2486.860

100.0

1234.96

$31.17 \quad 261.54$

100.0 


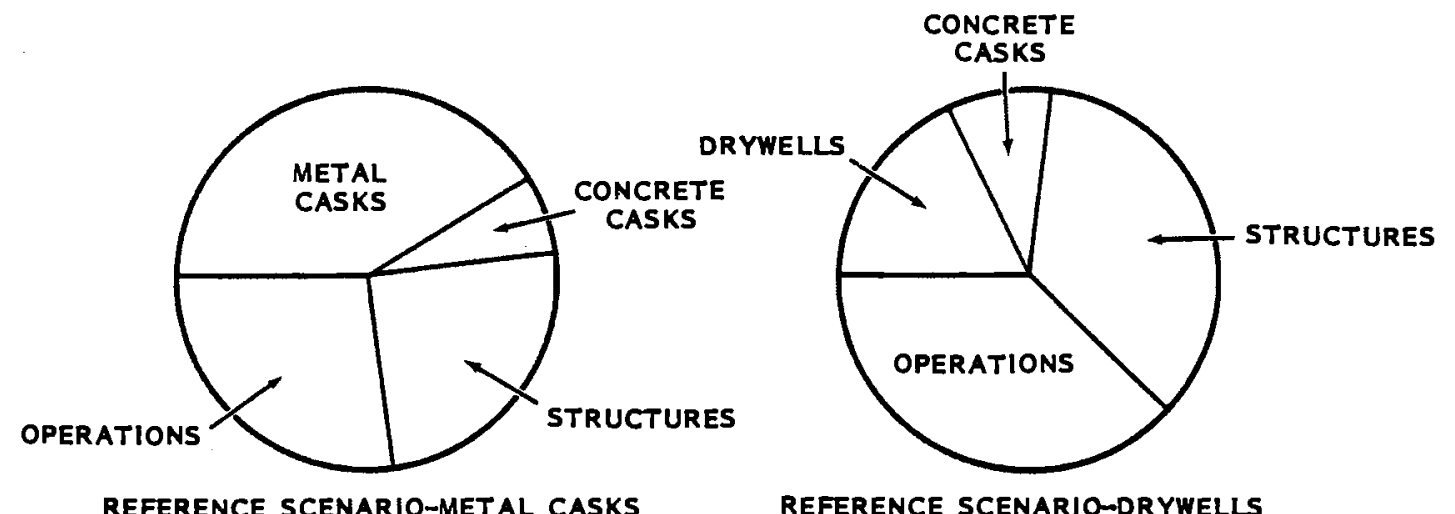

REFERENCE SCENARIO-METAL CASKS

REFERENCE SCENARIO-DRYWELLS

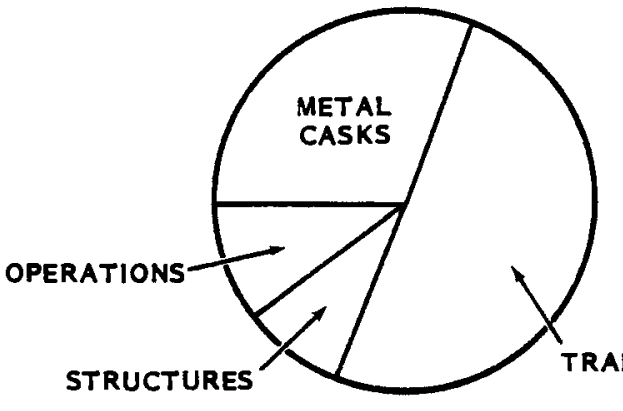

DELAYED REPROCESSING-METAL CASKS

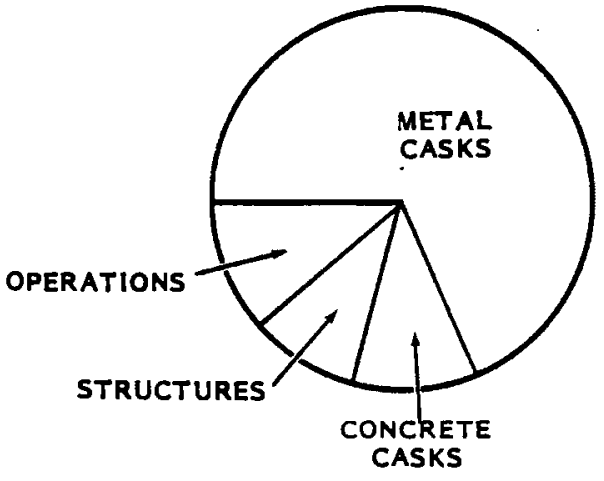

DELAYED DISPOSAL-METAL CASKS

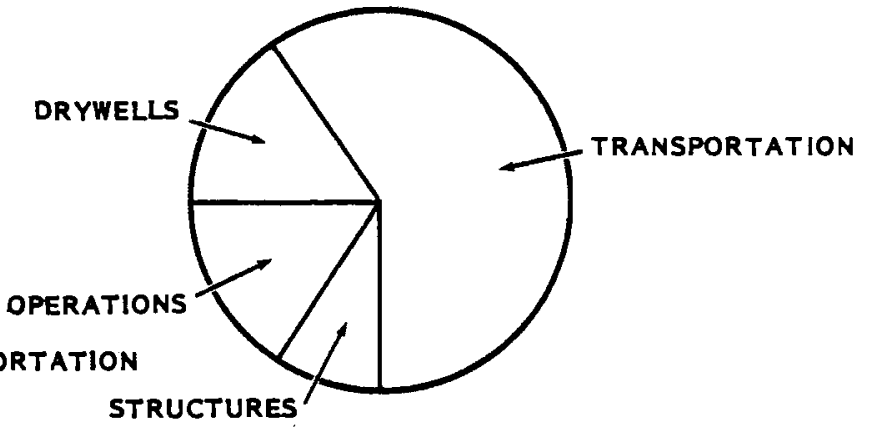

DELAYED REPROCESSING-DRYWELLS

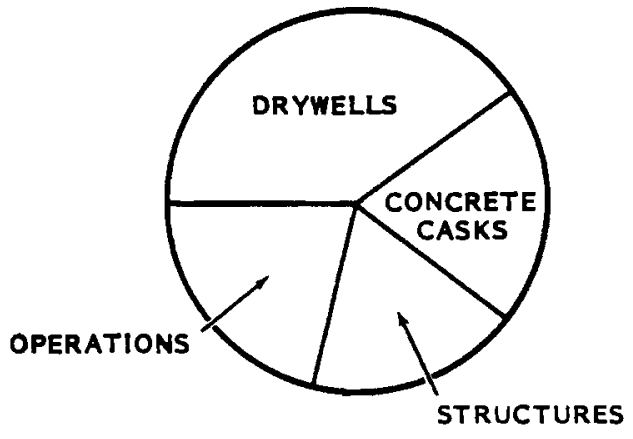

DELAYED DISPOSAL-DRYWELLS

FIGURE 6.1. Fractions of Total Undiscounted Life Cycle Cost Attributable to Each Component of Cost, for Each Scenario and Storage Alternative 


\subsubsection{Comparison of Metal Storage Casks with Drywells}

The total life cycle costs for each of the alternatives considered in this analysis are summarized in Table 6.2. The cost reduction obtained by utilizing drywells for storage of spent fuel and HLW canisters ranges from $\$ 213$ million to over $\$ 1.25$ billion. While many more drywells than metal casks are needed to store the same quantity of material, the greatly reduced capital cost of the reference drywell as compared with the reference metal cask $(\$ 18,000$ versus $\$ 875,000)$ makes the drywell a reasonably attractive alternative for locations suitable for drywell installation.

Possible disadvantages of drywells compared with storage casks are the much larger land surface area needed, the greater difficulty of decontamination and removal from the ground, and the perception of permanence that is engendered by the emplacement of the well assembly into the ground. Another disadvantage of drywells relative to metal casks is that the drywells can only be used for storage at the installed location while the metal casks can be transported to other locations for use, if appropriate.

TABLE 6.2. Undiscounted and Discounted Life Cycle Costs for the Scenarios and Storage Alternatives Studied (billions of mid-1982 dollars)

\begin{tabular}{|c|c|c|}
\hline & $\begin{array}{c}\text { Delayed } \\
\text { Reprocessing }\end{array}$ & $\begin{array}{l}\text { Delayed } \\
\text { Disposal }\end{array}$ \\
\hline
\end{tabular}

Undiscounted Cost:

$\begin{array}{lccc}\text { Metal Casks } & 0.731 & 2.257 & 2.487 \\ \text { Drywells } & 0.518 & 1.973 & 1.235 \\ \text { Casks } \rightarrow \text { Drywells } & -0.213 & -0.284 & -1.252 \\ \Delta \text { Cost } & -29.1 & -12.6 & -50.3 \\ \% \text { Change } & & & \\ & & & \\ \text { Discounted Cost: } & 0.578 & 1.592 & 1.661 \\ \text { Metal Casks } & 0.412 & 1.376 & 0.868 \\ \begin{array}{l}\text { Drywells } \\ \text { Casks } \rightarrow \text { Drywells }\end{array} & & & \\ \Delta \text { Cost } & -0.166 & -0.215 & -0.793 \\ \% \text { Change } & -28.7 & -13.6 & -47.7\end{array}$




\subsubsection{Possibilities for Cost Reduction}

It is instructive to review Figure 6.1 to select components of cost that should be examined for possible cost reductions. Since transportation of radioactive materials to and from the MRS/IS facility comprises from about 54 to 61 percent of the total life cycle cost of the system for the Delayed Reprocessing Scenario, transportation is a logical cost component to consider first.

Two alternatives to reduce the cost of transportation for the MRS/IS system are considered. These are: 1) consolidation of spent fuel bundles at the source site before shipment, thus reducing the number of shipments by a factor of 2, and 2) utilization of the large metal storage cask to ship spent fuel and solidified HLW from the source site to the MRS/IS facility, thus reducing the number of shipments by a large factor. These alternatives are discussed in the following subsections.

\subsubsection{Consolidation of Spent Fuel Assemblies}

Consolidating spent fuel assemblies into closely packed arrays with in containers results in packing the equivalent of two assemblies into the space formerly occupied by one assembly. Three cost components are affected by consolidation: transportation, storage containers, and storage pads. The number of spent fuel shipments is reduced by half, as is the number of metal casks or drywells required to store the spent fuel. The estimated values for these cost components with the fuel assemblies unconsolidated and consolidated are given in Table 6.3 , where it is seen that the possible cost reduction resulting from fuel consolidation is about $\$ 934 \mathrm{million}$, or over 41 percent of the life cycle cost for the Delayed Reprocessing scenario.

\subsubsection{Shipment in Large Metal Storage Casks}

The spent fuel and HLW canisters are assumed to be shipped 50 percent by volume by truck and 50 percent by volume by rail. If it were possible to license the reference metal storage cask for shipment of spent fuel and HLW canisters, the number of shipments could be greatly reduced. While incremental transportation cost is a contributor to the MRS/IS facility life cycle cost 
TABLE 6.3. Effect of Fuel Assembly Consolidation on MRS/IS

System Life Cycle Costs $(a, b)$

Cost Component

Unconsolidated:

Transportation

(Incrementa l)

Metal Casks

Pads/Fields

Total

Consolidated:

Reduction in Total

Life Cycle Cost

$\Delta$ Cost

$\%$ Reduction
Delayed

Reprocessing

1193.139

674.625

1.360

1869.124

934.562

934.562

41.4

(a) Millions of mid-1982 dollars, und iscounted.

(b) The number of significant figures is for computational accuracy and does not imply precision to the nearest $\$ 1000$.

only for the Delayed Reprocessing scenario, transportation is a major factor in overall waste management system costs. The effect on total waste management system cost of using the reference storage cask for shipment is illustrated in Table 6.4.

The possible waste management cost reductions resulting from utilization of the reference metal storage cask for shipment of spent fuel and HLW canisters range from $\$ 259$ million to over $\$ 1.2$ billion, depending upon the scenario.

6.1.2.3 Combined Effect of Fuel Consolidation and Storage Cask Transport

It is useful to examine the total reductions in waste management costs that can be obtained by utilizing both fuel consolidation and storage cask transport.

The combined effect of fuel consolidation and use of metal storage casks for transport and storage of spent fuel and HLW canisters is shown in Table 6.5. 
TABLE 6.4. Effect of Snipment in Metal Storage Casks on Waste Management System Costs $(a, b)$

\begin{tabular}{|c|c|c|c|}
\hline Cost Component & $\begin{array}{l}\text { Reference } \\
\text { Scenario }\end{array}$ & $\begin{array}{c}\text { Delayed } \\
\text { Reprocessing } \\
\end{array}$ & $\begin{array}{l}\text { Delayed } \\
\text { Disposal }\end{array}$ \\
\hline $\begin{array}{l}\text { Transport in } \\
\text { Standard Casks: } \\
\text { Spent Fue } 1 \\
\text { HLW }\end{array}$ & 291.875 & $\begin{array}{c}1312.600 \\
-\end{array}$ & 1283.630 \\
\hline $\begin{array}{l}\text { Transport in } \\
\text { Storage Casks: } \\
\text { Spent Fuel } \\
\text { HLW }\end{array}$ & 27.171 & 59.853 & 156.813 \\
\hline $\begin{array}{l}\text { Reduction in Waste } \\
\text { Management Cost }\end{array}$ & 264.704 & 1252.747 & 1126.817 \\
\hline
\end{tabular}

(a) Millions of mid-1982 dollars, undiscounted.

(b) The number of significant figures is for computational accuracy and does not imply precision to the nearest $\$ 1000$.

TABLE 6.5. Combined Effect of Fuel Consolidation and Shipment in Storage Casks on Waste Management System Costs $(a, b)$

\begin{tabular}{|c|c|c|c|}
\hline Cost Component & $\begin{array}{l}\text { Reference } \\
\text { Scenario }\end{array}$ & $\begin{array}{c}\text { Delayed } \\
\text { Reprocessing }\end{array}$ & $\begin{array}{l}\text { Delayed } \\
\text { Disposal }\end{array}$ \\
\hline $\begin{array}{l}\text { Transport in Standard } \\
\text { Casks Unconsol idated: } \\
\text { Spent Fuel } \\
\text { HLW } \\
\text { Storage (Spent Fuel) } \\
\text { Total }\end{array}$ & $\begin{array}{l}291.875 \\
291.875\end{array}$ & $\begin{array}{c}1312.600 \\
-- \\
675.985 \\
1988.585\end{array}$ & $\begin{array}{l}1283.630 \\
1283.630\end{array}$ \\
\hline $\begin{array}{l}\text { Transport in Storage } \\
\text { Casks Consolidated: } \\
\text { Spent Fuel } \\
\text { HLW } \\
\text { Storage (Spent Fuel) } \\
\text { Total }\end{array}$ & 27.171 & $\begin{array}{c}29.927 \\
-\overline{-} \\
337.993 \\
367.920\end{array}$ & 156.813 \\
\hline $\begin{array}{l}\text { Reduction in Waste } \\
\text { Management cost }\end{array}$ & 264.704 & 1620.665 & 1126.817 \\
\hline
\end{tabular}

(a) Millions of mid-1982 dollars, undiscounted.

(b) The number of significant figures is for computational accuracy and does not imply precision to the nearest $\$ 1000$. 
As shown in Table 6.5 , the possible waste management cost reductions resulting from the combination of fuel consolidation and storage cask shipment range from about $\$ 265$ million to over $\$ 1.6$ billion, depending upon the scenario.

\subsection{ADVANTAGES AND DISADVANTAGES OF CO-LOCATION}

The principal advantage of co-locating a storage facility with a geologic repository is that the structures and services installed for the storage facility become the surface facilities for the repository when the repository is placed in operation. Duplication of facilities is avoided, thus reducing the total capital investment in facilities for the waste management system by nearly $\$ 200$ million, as compared with equivalent facilities located separately.

Another related advantage is that the surface facilities remain in useful service over the combined lifetimes of the storage facility and the repository. The capital investment in facilities can be amortized over a period of more than 40 years rather than the 15 to 20 years appropriate for just the storage facility, thus reducing the cost to electricity customers due to waste management.

Since transport of the radioactive materials through the waste management system is the principal component of the system cost, it is desirable to minimize the length and number of shipments that must be made. The advantage or disadvantage of an MRS/IS/Repository facility for reducing transport costs depends largely on the scenario that is considered. In a situation like the Delayed Reprocessing scenario, where spent fuel assemblies are first shipped to the storage facility and stored, then to the reprocessing plant for reprocessing, and finally to a repository for disposal, the MRS/IS/Repository is a definite disadvantage since it would tend to maximize transportation costs. On the other hand, if the reprocessing plant is placed in operation early enough to avoid any interim storage of spent fuel, the MRS/IS/Repository will receive only solidified HLW and TRU wastes for eventual emplacement in the repository, and transport costs will be minimized. 
Another advantage of the MRS/IS/Repository is that the stored material can be transferred directly from storage to the repository, using the same transporter equipment as was used to place the material in storage initially. No shipments beyond the site boundary would be required, minimizing the potential for transportation accidents and the possible exposure of the public resulting from such accidents.

\subsection{RECOMMENDATIONS}

Because transportation of the radioactive materials to the storage site is the largest component of the system life cycle cost, those actions that will reduce transport costs should be implemented to the extent possible. The action to be taken first should be the consoliaation of all spent fuel assemblies prior to shipment from the source site(s). For compatibility with the internal structures of shipping and storage casks, the consolidated rods must be contained in canisters whose dimensions match those of an intact fuel assembly. Consolidation of fuel assemblies for storage has been demonstrated on an experimental basis in reactor fuel pools. Scaling these efforts up for production-level consolidation is within the present state-of-the-art, and should be a licensed process in the near future.

The next immediate beneficial action should be the licensing of the large storage casks for shipment when filled with spent fuel or HLW canisters. Should licensing be accomplished before any shipments are made to the storage facility, most of the structures at the facility would be unnecessary, since the radioactive material would be sealed in the storage cask at the source site. All that would be required at the storage site would be the capability to remove the cask from its rail car and to place the cask on its storage pad. The shielded handling facility would not be required until the repository is opened and the materials sealed in casks are removed for emplacement in the repository.

The use of the reference metal storage casks is a very costly approach for storing the large quantities of material postulated in the three principal scenarios. In the Delayed Disposal scenario, 2020 casks are needed, at a 
cost of nearly $\$ 1.8$ billion. The use of the reference drywells in the same scenario would cost just over $\$ 0.5$ billion. On a cost-effectiveness basis, the drywells should be the preferred choice.

Another consideration is the availability of the raw materials needed to fabricate the casks or drywells. About 50 tons of lead is used in each of the reference metal casks, or a total of about 100,000 tons for the Delayed Disposal scenario. Slightly smaller quantities of stainless steel would be required. The drywells would require essentially no lead and greatly reduced quantities of stainless steel, another factor favoring the drywell concept.

A recent analysis by Kaiser Engineers has suggested that water pool storage for spent fuel is about equivalent in cost to drywell storage. While not analyzed in this study, in view of the massive quantities of material that would be stored under the Delayed Disposal scenario, a water pool storage facility may be the most cost-effective approach. A detailed analysis of a water pool facility should be made before embarking on the establishment of a cask or drywell facility. 


\subsection{SENSITIVITY OF ESTIMATED COSTS TO VARIATIONS}

IN CONCEPTS AND ASSUMPTIONS

The scope of this study is limited to dry storage concepts: metal casks, and drywells. The prior assumption is made, perhaps erroneously, that either of the dry storage concepts can be developed and utilized for a monitored retrievable storage/interim storage (MRS/IS) facility on a more cost-effective basis than can the fully-developed and demonstrated water pool storage concept.

The principal components of cost are listed in Table 7.1 for the three scenarios considered. Also shown in the table are the percent changes in life cycle costs that are estimated to result from using a different storage device (drywell instead of metal cask), from consolidating the spent fuel assemblies at the source site(s) prior to shipment, and from shipping the radioactive materials to the storage facility in the large metal storage casks.

As might be expected, the Delayed Reprocessing and Delayed Disposal scenarios are more costly than the Reference scenario by about a factor of 3 . This result suggests that placing the reprocessing plants and the repositories in operation at the earliest possible time would also minimize the life cycle cost for the MRS/IS facility.

The major component of cost for the delayed reprocessing scenario ( $\sim 4$ percent) is the transporting of the spent fuel to and/or from the MRS/IS facility. Since the total waste management system cost for each of the three scenarios evaluated is very sensitive to transportation costs, ways and means to reduce transportation costs should be developed and applied in the selected waste processing system. For example, if incorporated into the commercial nuclear waste system, the concept of consolidating fuel assemblies at the reactor sites would not only reduce the transport costs but would also reduce the capital and operating costs of the MRS/IS facility. As shown in Table 7.1, fuel consolidation is estimated to produce a net reduction in MRS/IS facility costs of 41.4 percent for the Delayed Reprocessing scenario. This total includes possible reductions in transportation charges, purchase of fewer storage casks and construction of fewer storage cask pads and fields. 
TABLE 7.1. Estimated Life Cycle Costs and Possible Variations

\begin{tabular}{|c|c|c|c|}
\hline & \multicolumn{3}{|c|}{ Scenario } \\
\hline & Reference & $\begin{array}{c}\text { Delayed } \\
\text { Reprocessing }\end{array}$ & $\begin{array}{l}\text { Delayed } \\
\text { Disposal } \\
\end{array}$ \\
\hline $\begin{array}{l}\text { Total Undiscounted Cost } \\
\text { ( } \$ \text { Billions) }\end{array}$ & 0.731 & 2.257 & 2.487 \\
\hline \multicolumn{4}{|l|}{$\begin{array}{l}\text { Total Cost } \\
\text { Breakdown (by } \% \text { ) }\end{array}$} \\
\hline $\begin{array}{l}\text { Structures } \\
\text { Metal Cask } \\
\text { Concrete Cask } \\
\text { Pads/fields } \\
\text { Operations } \\
\text { Shipping (Incremental) }\end{array}$ & $\begin{array}{r}24.3 \\
41.9 \\
5.8 \\
0.6 \\
27.4 \\
0.0\end{array}$ & $\begin{array}{r}7.8 \\
29.9 \\
-- \\
0.1 \\
9.4 \\
52.9\end{array}$ & $\begin{array}{r}7.6 \\
71.1 \\
9.8 \\
1.1 \\
10.5 \\
0.0\end{array}$ \\
\hline $\begin{array}{l}\text { Fuel Consolidation at } \\
\text { Reactor Sites (\% change) }\end{array}$ & & -41.4 & \\
\hline $\begin{array}{l}\text { Ship in Storage } \\
\text { Cask (\% change) }\end{array}$ & -36.2 & -50.2 & -45.3 \\
\hline $\begin{array}{l}\text { Fuel Consolidation and } \\
\text { Shipment in Storage } \\
\text { Casks (\% change) }\end{array}$ & -36.2 & -66.5 & -45.3 \\
\hline $\begin{array}{l}\text { Drywe } 11 \text { s in lieu of } \\
\text { Casks (\% change) }\end{array}$ & -29.1 & -12.6 & -50.3 \\
\hline
\end{tabular}

This approach would also lessen the demands on items such as stainless steel, lead, boron steel and other scarce and expensive materials.

Another concept that, if developed and used in the commercial nuclear waste storage system, would also reduce costs is the use of a common cask for both shipment and storage. The reduction of 50.5 percent for the Delayed Reprocessing scenario (as shown in Table 7.1) represents savings due to the reduction in the number of cask shipments required.

If both fuel consolidation and shipment using large metal storage casks were implemented, estimated cost reductions of $36.2,66.5$, and 45.3 percent for the Reference, Delayed Reprocessing, and Delayed Disposal scenarios, respectively, could be realized. 
The potential cost reductions, if drywells were used for the storage of spent fuel and HLW instead of surface casks, are significant for each of the three scenarios, as shown in Table 7.1. Although the use of drywells is not analyzed in depth in this study, it is felt that their use would result in considerable reduction in the demands on stainless steel, lead, and other gamma-shielding materials.

Since the majority of the structures that make up the MRS/IS facility co-located with a repository can and will also serve as the basic surface facility for the repository, the overall costs to the commercial nuclear waste system can be reduced by using the co-located facilities. As shown in Table 4.7, the capital cost of the MRS/IS facility is about $\$ 180$ million. If separate MRS/IS facilities and repository surface facilities were to be built, the combined facility cost would approximately double.

In addition to reduced capital costs, the operating and decommissioning costs for a co-located facility would also be less than the associated costs for an MRS/IS facility and a repository that are separated.

As noted previously, the scope of this study does not include the "wet" storage concept. However, considering the need to provide a relatively large storage capacity in the very near time frame that would be required to operate for about 20 to 30 years, it appears that water pool storage is an option worthy of further consideration. It definitely would be one that would not require such large quantities of stainless steel, lead, and other scarce or expensive shielding materials.

One of the basic ground rules of this study is that only one MRS/IS facility would be built for the system required to handle and store nuclear wastes from commercial reactors. However, based on the magnitude of the transport requirements and costs as compared to facility costs for all of the scenarios studied, it may be prudent and cost-effective to use two MRS/IS facilities in the commercial waste system. While this concept has not been evaluated in any depth, it appears that the most cost-effective system may be one with an MRS/IS facility at both the reprocessing plant and at the site of the first repository. 


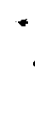




\subsection{TECHNICAL STATUS/RESEARCH AND DEVELOPMENT REQUIREMENTS}

The methods and systems to be used at a monitored retrievable storage/interim storage (MRS/IS) facility are, for the most part, well within the state-of-the-art and most have either been used or demonstrated at various facilities in the United States or abroad. The status of the principal components and areas needing further research and development are discussed in this section.

\subsection{RECEIVING AND HANDLING}

A considerable amount of experience has been gained in the use of rail and truck casks, both wet and dry, for the transportation of irradiated fuel elements in the United States.

Shipping cask unloading and fuel handling storage have been routinely performed at two reprocessing plants and in the spent fuel storage basin at commercial LWRs for a number of years. Dry receiving, unloading and storage have been considered and proposed in a number of different types of facilities ranging from reprocessing plants to repositories; they have been performed at the Nevada Test Site (NTS) in support of both the Spent Fuel Dry Surface Storage Program conducted by ONWI at the E-MAD facility and the disposal demonstration program conducted by the Lawrence Livermore Laboratory at the CLIMAX facility.

Transporter/emplacement systems for use with both casks and drywells of equivalent weight and configuration being considered for the MRS/IS facility have been demonstrated at E-MAD as part of the Spent Fuel Surface Storage Program.

\subsection{STORAGE}

Drywell development programs and projects at NTS, Hanford and the Idaho National Engineering Laboratory (INEL) have all provided experience with procedures and equipment, heat transfer data in soil and confirmation of the feasibility of the method. 
The use of drywells has been demonstrated at NTS/E-MAD as part of the Spent Fuel Surface Storage Program. Drywells have been used to store HTGR and LMFBR fuels at INEL for over ten years.

Surface storage casks have also been demonstrated at NTS under the Spent Fuel Surface Storage Program. In addition, large surface storage casks have been used for spent fuel storage and for storage demonstrations in both Canada and West Germany.

Required storage monitoring such as gas sampling and measuring, and temperature measuring systems are all well developed and can be applied to either storage concept.

\subsection{RESEARCH AND DEVELOPMENT REQUIREMENTS}

As noted above, the general systems and components required at an MRS/IS facility have been developed and demonstrated. It is anticipated that the R\&D requirements will essentially be the same for all MRS/IS facilities no matter where they are located. An exception for the MRS/IS/Repository is that geological, hydrological and geotechnical exploration and data evaluation will be required to assure the facility is located on an acceptable and viable geologic repository site.

The need to achieve a relatively high facility throughput and capacity will require additional development and improvements to some of the present systems and methods. Specific devices for monitoring and safeguard applications will need to be developed and refined. Additional R\&D efforts will be required to develop:

- licensed truck and rail casks designed for dry mode transfers of contents

- licensed shippable storage casks

- efficient licensed TRU waste containers and shipping casks

- standardized and licensed waste containers. 
Development and testing will be requireo to:

- confirm the heat rejection capabilities of large surface storage casks

- establish drywell heat transfer parameters for site-specific environments

- establish large surface storage cask heat transfer parameters for site-specific environments.

Development and prototype testing should be conducted on:

- grapples to handle canisters and waste packages

- automated cask decontamination station

- remotely operated contamination detection equipment

- container leak testing systems. 


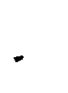




\section{APPENDIX A}

CONSIDERATIONS FOR MRS/IS COST EVALUATION 
APPENDIX A

\section{CONSIDERATIONS FOR MRS/IS COST EVALUATION}

The MRS/IS facility is conceived as a government-owned facility for providing temporary storage capability for spent fuel and/or reprocessing wastes while reprocessing capability and repositories for geologic disposal are introduced.

To provide compatibility with other studies performed in evaluation of spent fuel and waste disposal, all costs should be presented in terms of constant-value, mid-1982 dollars (without cost escalation or inflation). All costs from the present to the final year of decommissioning are to be entered into a cash flow table (Table A.1) and presented both as undiscounted costs and as discounted at 2 percent per year. The annual costs should be summed over all years included, to provide undiscounted program costs and the present worth costs at 2 percent discount. The discounted (present worth) costs will be used in comparing alternatives.

To ensure that all alternatives are equitably treated during comparisons, the details of component costs, background, and cost bases must be presented in support of the costs given in Table A.1. Tables A.2 through A.7 are provided for this purpose. These tables in turn should be supported by the cost schedules indicating the cost bases or components for each category in the tables. Typical cost categories are outlined in Attachment 1, following these tables. Insofar as possible, cost breakdowns by these categories should be provided. If other cost bases are used, these should be detailed.

Table A.2 summarizes the capital construction costs for the first module of the MRS/IS; costs for additional modules should be entered on Table A.6 (in multiple copies if needed). Costs for each module should be prorated into the appropriate years, using Table A.3, and the prorated annual costs should then be included in the cash flow summary of Table A.1.

Owner's costs are defined separately for three periods: those costs incurred during the construction period (Table A.5), annual operating costs for the facility (Table A.6), and decommissioning costs (Table A.7). The costs summarized on Tables $A .5$ and $A .7$ should, as before, be prorated into the appropriate years using Table A.3. 
TABLE A.1. Cash Flow and Present Worth for

\begin{tabular}{|c|c|c|c|c|c|}
\hline \multirow[b]{2}{*}{ Year } & \multirow[b]{2}{*}{$\begin{array}{l}\text { Discount } \\
\text { Factor } \\
\end{array}$} & \multicolumn{4}{|c|}{ Costs, $\$ 1000$ 's } \\
\hline & & Capital & Operating & Total & $\begin{array}{c}\text { Discounted } \\
\text { Total } \\
\end{array}$ \\
\hline 1982 & 1.000 & & & & \\
\hline 1983 & 0.9804 & & & & \\
\hline 1984 & 0.9612 & & & & \\
\hline 1985 & 0.9423 & & & & \\
\hline 1986 & 0.9238 & & & & \\
\hline 1987 & 0.9057 & & & & \\
\hline 1988 & 0.8880 & & & & \\
\hline 1989 & 0.8706 & & & & \\
\hline 1990 & 0.8535 & & & & \\
\hline 1991 & 0.8368 & & & & \\
\hline 1992 & 0.8203 & & & & \\
\hline 1993 & 0.8043 & & & & \\
\hline 1994 & 0.7885 & & & & \\
\hline 1995 & 0.7730 & & & & \\
\hline 1996 & 0.7579 & & & & \\
\hline 1997 & 0.7430 & & & & \\
\hline 1998 & 0.7284 & & & & \\
\hline 1999 & 0.7142 & & & & \\
\hline 2000 & 0.7002 & & & & \\
\hline 2001 & 0.6864 & & & & \\
\hline 2002 & 0.6730 & & & & \\
\hline 2003 & 0.6598 & & & & \\
\hline 2004 & 0.6468 & & & & \\
\hline 2005 & 0.6342 & & & & \\
\hline
\end{tabular}


TABLE A.1. (contd)

\begin{tabular}{|c|c|c|c|c|c|}
\hline \multirow[b]{2}{*}{ Year } & \multirow[b]{2}{*}{$\begin{array}{l}\text { Discount } \\
\text { Factor } \\
\end{array}$} & \multicolumn{4}{|c|}{ Costs, $\$ 1000$ 's } \\
\hline & & Capital & Operating & Total & $\begin{array}{c}\text { Discounted } \\
\text { Total } \\
\end{array}$ \\
\hline 2006 & 0.6217 & & & & \\
\hline 2007 & 0.6095 & & & & \\
\hline 2008 & 0.5976 & & & & \\
\hline 2009 & 0.5859 & & & & \\
\hline 2010 & 0.5744 & & & & \\
\hline 2011 & 0.5631 & & & & \\
\hline 2012 & 0.5521 & & & & \\
\hline 2013 & 0.5412 & & & & \\
\hline 2014 & 0.5306 & & & & \\
\hline 2015 & 0.5202 & & & & \\
\hline 2016 & 0.5100 & & & & \\
\hline 2017 & 0.5000 & & & & \\
\hline 2018 & 0.4912 & & & & \\
\hline 2019 & 0.4806 & & & & \\
\hline 2020 & 0.4712 & & & & \\
\hline 2021 & 0.4619 & & & & \\
\hline 2022 & 0.4529 & & & & \\
\hline 2023 & 0.4440 & & & & \\
\hline 2024 & 0.4353 & & & & \\
\hline 2025 & 0.4268 & & & & \\
\hline 2026 & 0.4184 & & & & \\
\hline 2027 & 0.4102 & & & & \\
\hline 2028 & 0.4022 & & & & \\
\hline 2029 & 0.3943 & & & & \\
\hline 2030 & 0.3865 & & & & \\
\hline
\end{tabular}

SUM

A. 3 
TABLE A.2. First Module Capital Cost Estimate for

Cost Element

Manhours, 1000 's

Non-Manual Manual
Costs, $\$ 1000^{\prime} s$

Labor Material Total

Site and improvments

Receiving facility

Canning facility

Drywells or casks

Balance of storage facility

Other buildings

Canning equipment

Transporter

other engineered equipment

Total directs

Indirects

A-E services

Contingency

TOTAL 
A.3. Cost Distribution for

(from Tables B.20, B.22 and B.25

Year Distribution Fraction Annual Cost 
TABLE A.4. Estimate of Additional Module Capital Cost for

Cost Element

Manhours, $1000^{\prime} \mathrm{s} \quad$ Costs, $\$ 1000^{\prime} \mathrm{s}$

Non-Manual ManuaT Labor Material Total

Site preparation

Drywells or casks

Balance of storage facility

Total directs

Indirects

A-E services

Contingency

TOTAL 
TABLE A.5. Estimate of Owner's Costs During Construction for

Manhours

Cost Element or Other Basis Cost

Hearing preparation and testimony

Contract management

Inspection and $Q A$

Training program

Security

Genera] and Administrative

TOTAL 
TABLE A.6. Estimate of Owner's Annual Operating Costs During for

Manhours

Cost Element or Other Basis Cost

Supplies

Capital replacement allowance

Cans and lids

Security

Maintenance

Receiving and shipping

Hot cell (canning, etc.)

Placement or removal

Surveillance

Outside support services

Subtotal

General and Administrative

Utility costs

other

TOTAL ANNUAL COST 
TABLE A.7. Estimate of Owner's Costs During Decommissioning for

Manhours

Cost Element or Other Basis Cost

Casks or drywells

Engineered equipment

Buildings

Site restoration

Supplies (decontamination, cutting, packaging)

Security

Shipping and burial fees

Subtotal

General and administrative

Utilities

Other

TOTAL 
Table A.6 should be used for estimates of annual operating costs. Normally one table will be required for each year of operation. However, if operating costs are identical for successive years, a single table may be used with the notation in the heading as to the years the table applies to. Again, the total cost for each year should be included in the cash flow summary of Table A.1. Transportation-related expenses inside the facility fence (except transportation equipment lease or use fees) are to be estimated and included in annual operating expenses.

\section{Cost Bases}

Bases for estimates should be given in all instances. Design and construction costs are generally influenced by physical conditions at a site. Attachment 2 lists the pertinent conditions that should be described as part of this cost basis. Attachment 3 provides guidelines for social and economic factors that need to be considered and described in the bases. These procedures, should be followed, are based upon work initially done for PNL by Bechtel Corporation during preparation of DOE/ET-0028 (Technology for Commercial Waste Management).

A contingency of 25 percent should be used in defining construction costs.

If the design does not require a facility or an operation given in a table, a cost of zero may be entered. The detail in the tables is not intended to dictate design, only to permit normalization. 


\section{ATTACHMENT 1: OUTLINE OF COST CATEGORIES}

A. Possible capital expenses at MRS/IS

1. Reports and testimony for site approval, cost of permits and licenses

2. Design engineering

3. Site preparation, access control, abatement of impacts on air and water quality

4. Buildings
a) Receiving facility including holding areas for incoming and outgoing casks
b) Canning facility, transfer facility
c) Storage facility including drywells or casks
a) Administration auxiliary, etc.

5. Engineered equipment

a) Cranes

b) Canning equipment

c) Decontamination and waste treatment equipment

d) Ventilation and contamination control

e) Spare parts inventory
f) Transporter for 100 ton cask or shielded transporter for cans

6. Contractor indirects (percent of 4,5 and 6)

7. Construction management and inspection

8. Licensing and safety reports

9. Contingency 
B. Owner's costs for MRS/IS

1. Payroll for personnel at hearings and for preparation of presentation and testimony

2. Contract management
a) Engineering
b) Licensing consultants
c) Construction contractor

3. Inspection and quality assurance

4. Operating supplies
a) Decontamination chemicals, wipes, protective clothing, dosimeters, etc.
b) Filter aids, demineralizers, regeneration chemicals
c) Annual capital replacement as used from spare parts inventory
d) Cans and lids

5. Payroll for personnel to:
a) Operate training program
b) Guard plant and storage yard
c) Maintain cranes, decontamination equipment, waste treatment equipment, heating and ventilating equipment, and transporter
d) Receive, prepare, inspect, survey, cool, flush, and decontaminate shipping casks, storage casks, and/or shielded transporter
e) Move shipping cask and storage cask into hot cell and open them
f) Bring fuel, fuel can, hardware can and lids to work station 
g) Disassemble fuel and place fuel pins in fuel cans and hardware in hardware cans

h) When cans are full, seal, test seal, decontaminate exterior and survey

i) Place completed cans in a cask, shielded transporter or lag storage

j) Mark each can and record the contents and location

k) Move fuel assemblies from shipping cask to storage cask or transporter or cans from storage to the storage cask or transporter

1) Close, inspect, survey and decontaminate a cask or shielded transporter

m) Reassemble and ship the shipping cask

n) Remove the storage cask from the hot cell and place in the storage yard

o) Remove the shielded transporter from the hot cell, place the fuel or can in a drywell, seal the drywell, test the seal, survey, and decontaminate.

6. Maintenance and operating supplies for the storage period.

7. Payroll during storage period
a) Guards
b) Maintenance to keep plant in standby and counteract weathering of casks or drywells
c) Leak test casks or drywells and repair as necessary

8. Maintenance and operating supplies for removal
a) Decontamination chemicals, wipes, etc.
b) Filter aids, demineralizer regeneration chemicals
c) Capital replacements as used from spare parts inventory. 
9. Payroll during removal for personnel to:

a) Guard plant and storage yard

b) Maintain cranes, decontamination equipment, waste treatment equipment, heating ventilating equipment and transporter

c) Receive, prepare, inspect, survey, cool, flush and decontaminate storage casks, shipping casks, and/or shielded transporter

d) Move storage cask or fuel from shielded transporter and shipping cask into hot cell and open casks

e) Move fuel assembly or can into shipping cask

f) Record location of all fuel moved

g) Close, inspect, survey and decontaminate casks and/or transporter

h) Prepare and ship the shipping cask to reprocessing or disposal (if storage cask becomes licensed for shipping, this step may replace many of the above steps)

10. Pay premium or receive credit for condition of fuel relative to normal uncanned assemblies based upon impact on reprocessing or disposal.

11. Decommission facility

a) Survey, decontaminate and sell for scrap, send to shallowland burial or disposal the storage casks or drywells

b) Decontaminate, disassemble, and sell for scrap or package and ship for shallow burial or disposal all engineered equipment

c) Convert to other use or demolish and sell for scrap or send to shallow burial or disposal all buildings and storage structures

d) Prepare land for conversion to other uses. 
12. Shipping and burial fees for decontamination wastes generated during fuel placement, storage, and removal, and during decommissioning.

13. General and overhead expenses (as a percentage of 4 through 12)

14. Contracted services.

15. Fuel and utilities. 


\section{ATTACHMENT 2: DESIGN AND CONSTRUCTION BASES}

Please describe the following items in your basis.

1. Site Location

2. Meterological Conditions

2.1 Wind conditions as indicated below:

- Maximum velocity

- Average velocity

- Design velocity (basic wind speed)

- Design pressure.

\subsection{Tornado}

2.3 Tornado Missiles

2.4 Rainfall (Precipitation)

- Annual average precipitation

- Maximum precipitation

- Design maximum rate (peak $1 \mathrm{hr}$ rate 50 yr recurrence)

- Design maximum duration.

2.5 Snow

2.6 Temperature design basis temperature conditions

- Summer maximum (July)

- Winter minimum (January)

- Design maximum, summer

dry buib

wet buib

- Design minimum, winter.

3. Surface Conditions

3.1 obstructions

3.2 Topography

3.3 Vegetation

3.4 Drainage 


\subsection{Flooding}

3.6 Roads

Approximate new road construction required to provide access to the site from an existing highway suitable for heavy transport.

\subsection{Railroads}

Approximate new railroad required to provide a rail spur service to the site.

\subsection{Utilities}

Will temporary facilities be required during construction, or are permanent facilities part of site preparation.

4. Subsurface Conditions

\subsection{Obstructions}

Are there any major underground obstructions to facility construction.

\subsection{Soils - Thickness}

4.3 Rock - Depth type and load bearing ability

4.4 Groundwater - Depth and need for dewatering

4.5 Frost - Design ground penetration

4.6 Cavities and Small Voids

Do they exist in the soils or rock underlying the site

5. Geologic and Seismic Conditions

5.1 Faults - The nearest known or inferred fault

\subsection{Seismic Design}




\section{ATTACHMENT 3: COST ESTIMATE BASES AND METHODS}

1. Construction Conditions

As a basis for cost estimating, the construction conditions described below are assumed to prevail at all sites.

1.1 Construction Labor will follow a 40-hour, single-shift work week schedule except for casual overtime (e.g., to complete a concrete pour), and in instances where twoor three-shift concrete work operations are planned to meet the construction schedule.

1.2 Severe Work Stoppages such as extensive jurisdictional disputes between labor crafts will not occur during construction.

1.3 Labor Availability in each craft will be adequate so that importing labor, except for general foremen, will not be required.

1.4 Craft Labor Wage Rates, including fringe benefits are those prevailing in the geographic region of the construction site in mid-1982.

\section{Pricing: Field Costs}

The various elements comprising the field costs will be priced by the methods described below:

2.1 Major Equipment Costs will be determined using estimated prices of similar or nearly similar equipment from other cost estimates of fuel reprocessing plants, radioactive wastes disposal processes and other plants dealing with the nuclear fuel cycle.

2.2 Bulk Materials. Except for instances where enough information exists to warrant quantity assessments and unit pricing of certain specifically identified material, bulk materials costs will be determined either as a function of major equipment costs or as a cost allowance.

2.3 Direct Labor Costs will be evaluated from estimated manhours for erection and installation sequences and operations and craft wage rates and fringe benefits in effect at mid-1982. Labor manhours are representative of the craft production rates in the area of reference jobsites. 
2.4 Indirect Site Construction Costs such as contractor's fee, supervision, construction equipment, tools and consumable supplies, temporary facilities and utilities, material handling, cleanup and the like will be combined and evaluated as a factor of the total direct labor.

3. Architect-Engineer (A-E) Services

The costs of A-E services will be estimated as a percentage of the total field costs and will include burden and fee.

4. Owner's Cost

Owner's costs during construction will be estimated in conjunction with the operating and maintenance costs.

5. Costs Not Included

Exclusions from the estimate are generally limited to the following particular cost classifications:

- Site acquisition costs

- Escalation of costs beyond mid-1982

- Process and patent royalties

- General research and development costs

- Costs incurred beyond those that reflect the current degree of involvement in securing approvals from regulatory agencies monitoring environmental and safety considerations

- Costs generated directly by any governing or regulatory agency for administration, engineering, procurement and construction

- Sales/use tax

- Local property tax or payments in lieu thereof

- Impact payments to local government

- Insurance or prorate cost of self insurance

- Nuclear hazards insurance that may be required if nuclear hazards exist on site before completion of project

- Housing for construction workers. 

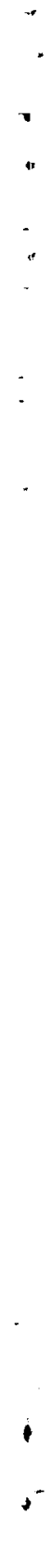
APPENDIX B

MRS/IS FUEL CYCLE AND WASTE SCENARIOS 


\section{MRS/IS FUEL CYCLE AND WASTE SCENARIOS}

Five MRS/IS scenarios are to be used by all MRS/IS projects. Each MRS/IS facility should be designed to satisfy the reference scenario, the delayed reprocessing scenario, and the delayed disposal scenario. The early disposal scenario and the delayed disposal-no reprocessing scenario are included for information only.

\section{Basis for Projections}

The bases and assumptions used in developing the projections are as follows:

- Maximum pool expansion at reactors is assumed based on utility estimates.

- Each pool maintains a full core reserve.

- Historic spent fuel inventory data are used as reported by utilities.

- Discharge projections used are as given by utilities.

- Generic reactors added beginning in 1996 have lifetime storage capability.

- TRU wastes are sent to disposal or storage the year after reprocessing.

- The maximum receiving rate for each repository for spent fuel or equivalent $\mathrm{HLW}$ is $1800 \mathrm{MTHM} / \mathrm{yr}$ the first five years and $3000 \mathrm{MTHM} / \mathrm{yr}$ for the next 21 years.

- The maximum TRU receiving rates are designed to be compatible with the HLW receiving rates and are about 15 percent greater than those rates in terms of equivalent MTHM. 
- Solidified HLW is sent to disposal or storage one year after reprocessing or 10 years after reactor discharge, whichever is later.

- Time from discharge is determined by youngest fuel in the mixture.

- 01dest fuel is shipped first to MRS/IS or reprocessing.

- Shipping the oldest fuel first is assumed to relieve the at-reactor storage problems.

- Spent fuel can be sent to disposal if the overflow from reactor basins is 10 years old and reprocessing is limited.

- The first two reprocessing plants have capacities of $1500 \mathrm{MTHM} / \mathrm{yr}$ and the next two have capacities of 3000 MTHM/yr.

- The fourth reprocessing plant is a replacement for the first plant, which is assumed to be retired after about 20 years service.

- Each reprocessing plant operates at $1 / 3$ and $2 / 3$ capacity in its first two years.

- Spent fuel requiring storage prior to 1990 is stored in casks at reactor sites or at government-owned emergency storage.

The startup dates for reprocessing plants and repositories which define the scenarios are summarized in Table B.1. MRS/IS activity concludes before 2025 for all except the delayed disposal scenario; a fourth repository is needed in the delayed disposal scenario to permit retiring the MRS/IS at a reasonable date.

\section{Reprocessing Plant Waste Quantities}

Reprocessing plant waste quantities are based on information provided by AGNS in a draft report. (a) The projection is based on:

- Compaction of the hulls (after separation of hardware) and other compactible and noncombustible wastes

(a) W. H. Carr, Estimation of Nuclear Waste from the Barnwell Nuclear Fuel Plant, Allied-General Nuclear Services, April 26, 1982 (Draft). 
TABLE B.1. Startup Dates for the Scenarios

\begin{tabular}{|c|c|c|}
\hline Scenario & Reprocessing & Disposal \\
\hline Reference & $1989,2000,2005,2010$ & $1998,2002,2015$ \\
\hline $\begin{array}{l}\text { Delayed } \\
\text { Reprocessing }\end{array}$ & $1999,2010,2015,2020$ & $1998,2002,2015$ \\
\hline Delayed Disposal & $1989,2000,2005,2010$ & $2008,2012,2015,2025$ \\
\hline Early Disposal(a) & $1989,2000,2005,2010$ & $1993,1998,2010$ \\
\hline $\begin{array}{c}\text { Delayed Disposal(a) } \\
\text { no Reprocessing }\end{array}$ & & $2008,2012,2015$ \\
\hline
\end{tabular}

(a) Information only

- Incineration of combustible wastes with cement immobilization of the ash and incinerator scrubber solution

- Immobilization of $U_{6}$ plant particulates with cement

- Volume reduction factors based on data developed for the GEIS on commercial radioactive waste (DOE/ET-0028)

- Use of a 2-ft diameter $\times 10-\mathrm{ft}$ long canister for hulls and other canistered wastes (excluding HLW). This size is assumed to be more compatible with storage and shipping casks than the 4-ft diameter $x$ 8-ft long canister.

The annual quantities of waste from the 1500 MT/yr AGNS plant are summarized in Table B.2 for the volume-reduced and immobilized wastes. Table B.2 also shows the number of HLW canisters, if a standard 1-ft diameter $\times 10-\mathrm{ft}$ long canister is used. The TRU wastes are divided into five surface dose rate categories: $0.2,0.2-5,5-50,50-500$, and $>500 \mathrm{R} / \mathrm{hr}$. Waste containers with surface dose rates greater than $0.2 \mathrm{R} / \mathrm{hr}$ are identified here as remote handled TRU (RHTRU). Those less than $0.2 \mathrm{R} / \mathrm{hr}$ are identified as 
TABLE B.2. Annual AGNS Plant HLW and TRU Wastes with Volume Reduction and Immobilization (per 1500 MTU)

\begin{tabular}{|c|c|c|c|c|c|c|c|}
\hline Waste & $\mathrm{ft}^{3} \mathrm{yr}$ & Container & $0.2 \mathrm{R} / \mathrm{hr}$ & $\underline{0.2-5}$ & $\underline{5-50}$ & $\underline{50-500}$ & $>500 \mathrm{R} / \mathrm{hr}$ \\
\hline HLW glass & 4,900 & $1 \mathrm{ft} D \times 10 \mathrm{ft} \mathrm{can}$ & -- & -- & -- & -- & 700 \\
\hline Hulls compacted & 9,600 & $1 \mathrm{ft} D \times 10 \mathrm{ft} \mathrm{can}$ & -- & -- & -- & -- & 340 \\
\hline Fuel hdwr. & 3,900 & $2 \mathrm{ft} D \times 10 \mathrm{ft} \mathrm{can}$ & -- & -- & -- & -- & 140 \\
\hline RHTRU & 1,600 & $2 \mathrm{ft} D \times 10 \mathrm{ft} \mathrm{can}$ & -- & 40 & 7 & 4 & -- \\
\hline RHTRU & 4,600 & 55 gal drums & -- & 614 & 76 & 8 & -- \\
\hline CHTRU & 1,380 & $4 \mathrm{ft} \times 6 \mathrm{ft} \times 6 \mathrm{ft} \mathrm{Stl}$. boxes & 25 & -- & -- & -- & -- \\
\hline CHTRU & 19,560 & 55 gal drums & 3,293 & -- & -- & -- & - \\
\hline Mox Plant & & & & & & & \\
\hline CHTRU & 10,400 & 55 gal drums & 1,575 & -- & -- & -- & -- \\
\hline CHTRU & 2,000 & $4 \mathrm{ft} \times 6 \mathrm{ft} \times 6 \mathrm{ft} \mathrm{stl}$. boxes & 15 & -- & -- & -- & -- \\
\hline
\end{tabular}


contact handled (CHTRU). The AGNS data included a category 0.05 to $0.5 \mathrm{R} / \mathrm{hr}$. For this analysis one-half the waste in that category is assumed to have a surface dose rate of less than $0.2 \mathrm{R} / \mathrm{hr}$ and, therefore, to be CHTRU. The remainder is assumed to be greater than $0.2 \mathrm{R} / \mathrm{hr}$ and, therefore, to be RHTRU. Scenario Projection

The reference scenario is summarized in Table B.3. All numbers on this table are expressed as metric tons of spent fuel or metric tons equivalent of HLW (i.e., metric tons of spent fuel reprocessed to produce the HLW). To convert from MTHM to fuel assemblies or HLW canisters, divide the listed MTHM values by 0.18 MTHM/BWR, 0.42 MTHM/PWR, 2.143 MTHM/Canister. Column headings can be defined as follows:

\begin{tabular}{|c|c|c|}
\hline Column & Label & Definition \\
\hline 2 & Discharge & MT spent fuel discharged per year \\
\hline 3 & AR Inv. & $\begin{array}{l}\text { At-reactor spent fuel storage } \\
\text { inventories, MT }\end{array}$ \\
\hline 4 & MRS Inv. & $\begin{array}{l}\text { Spent fuel inventory at the } \\
\text { MRS/IS, MT }\end{array}$ \\
\hline 4 & MRS Inv. & $\begin{array}{l}\text { Spent fuel inventory at the } \\
\text { MRS/IS, MT }\end{array}$ \\
\hline 5 & Reprocess & Reprocessing rate, MT/yr \\
\hline 6 & Disposal & $\begin{array}{l}\text { Spent fuel shipped to disposal, } \\
\text { MT/yr }\end{array}$ \\
\hline 7 & Disposal Inv. & $\begin{array}{l}\text { Spent fuel inventory in reposi- } \\
\text { tories, MT }\end{array}$ \\
\hline 8 & HLW AR & $\begin{array}{l}\text { HLW stored at reprocessing plant, } \\
\text { MT equivalent }\end{array}$ \\
\hline 9 & HLW MRS & HLW stored at MRS/IS, MT equivalent \\
\hline 10 & Disposal & HLW sent to disposal, MT/yr \\
\hline 11 & Disposal Inv. & $\begin{array}{l}\text { HLW inventories in repositories, } \\
\text { MT equivalent }\end{array}$ \\
\hline
\end{tabular}


TABLE B.3. Reference Scenario Summary (Reference Case June 21, 1982)

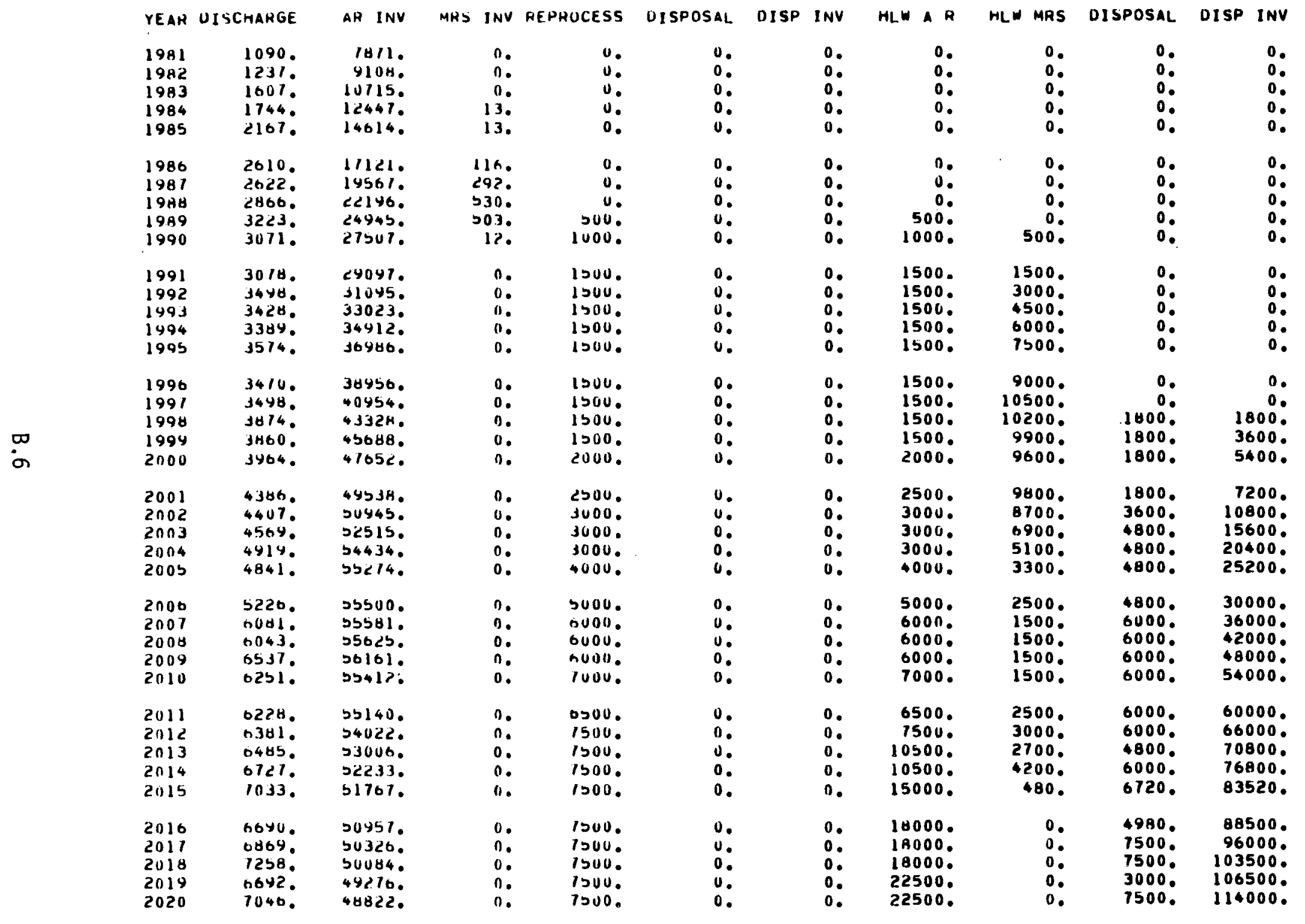


The 13 tons in MRS/IS before 1986 come from Surry-2. It is possible the ulitity will find another solution to its storage problem. Columns six and seven are provided for spent fuel disposal in other scenarios. Column eight represents the HLW inventory at the reprocessing plant, based on a minimum of one year hold up or until 10 years after reactor discharge.

Table B.4 contains the details of shipments of fuel and HLW to and from the MRS/IS. The left half of the table has BWR data and the right half PWR data. Positive numbers represent additions or shipment to the facility while negative values represent shipments or removals from the facility. In Table B.4, the amount of each shipment is given as the tonnes of heavy metal in the original fuel. Thus the HLW shipments must be converted to canisters to obtain storage requirements (see Table B.5). The exposure is the average exposure in $M W d / \mathrm{kg}$. The discharge year is the year the youngest fuel in the mixture was discharged.

Table B.6 contains similar data for TRU. On this table, the left-hand column of each pair represents TRU generated while reprocessing BWR fuel and the right-hand column of each pair represents TRU generated while reprocessing PWR fuel. Number of packages of treated wastes handled each year is also given in Table B.6. In addition to the data given in Table B.6, the MOX plant is assumed to produce one $4 \mathrm{ft} \times 6 \mathrm{ft} \times 6 \mathrm{ft}$ box for each 100 drums.

Tables B.7 and B.8 are similar to Tables B.3 and B.4 and present data for the delayed reprocessing scenario. Table B.8, however, does not include TRU since the MRS/IS will not receive any TRU in this scenario. Tables B.9-11 are similar to Tables B.4-6 and present data for the delayed disposal scenario. Tables B.12 through B.16 present data for the early disposal and delayed disposal-no reprocessing scenario and are for information only.

The spent fuel and HLW requirements at MRS/IS were summarized in Table B.5. The peak rates given in Tables B.4, B.8, and B.10 were averaged over 2 or 3 years since the peaks are the result of setting the age of a year's reprocessing plant production of HLW equal to the age of the youngest fuel in the mixture. This causes large and unrealistic variations in 
TABLE B.4. Reference Scenario, Fuel and HLW Shipments at MRS (Reference Case June 21, 1982)

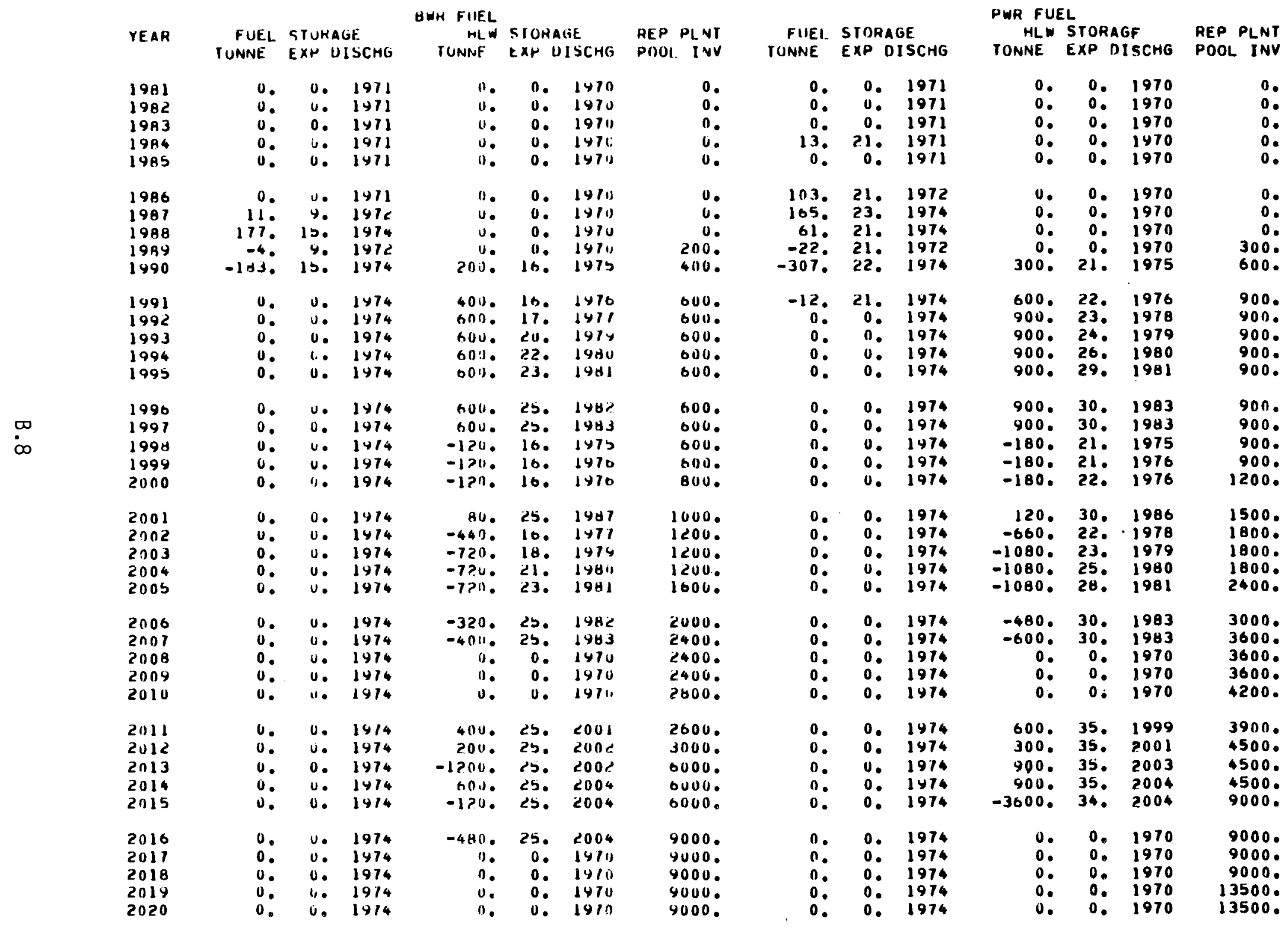


TABLE B.5. Spent Fuel and HLW (MTHM) Storage Capacity Requirements at MRS/IS Facility

Reference $\quad \begin{array}{cl}\text { Delayed } & \text { Delayed } \\ \text { Reprocessing } & \text { Disposal }\end{array}$

Fuel capacity

-(a)

7,547

(a)

HLW capacity

10,500

--

1,500

60,600

Annual receiving rate ${ }^{(b)}$

1,500

2,200

4,500

1,800

4,800

\footnotetext{
(a) No spent fuel in stored at MRS/IS facility prior to startup in 1990

(b) Peak rates averaged over 2 years.

(b) Peak rates averaged over 3 years.
} 
TABLE B.6. Reference Scenario, Number of TRU Packages Handled at MRS (Reference Case June 21, 1982)

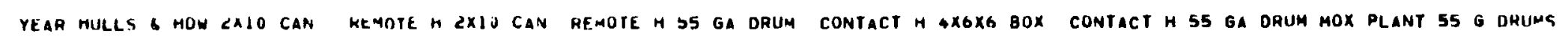

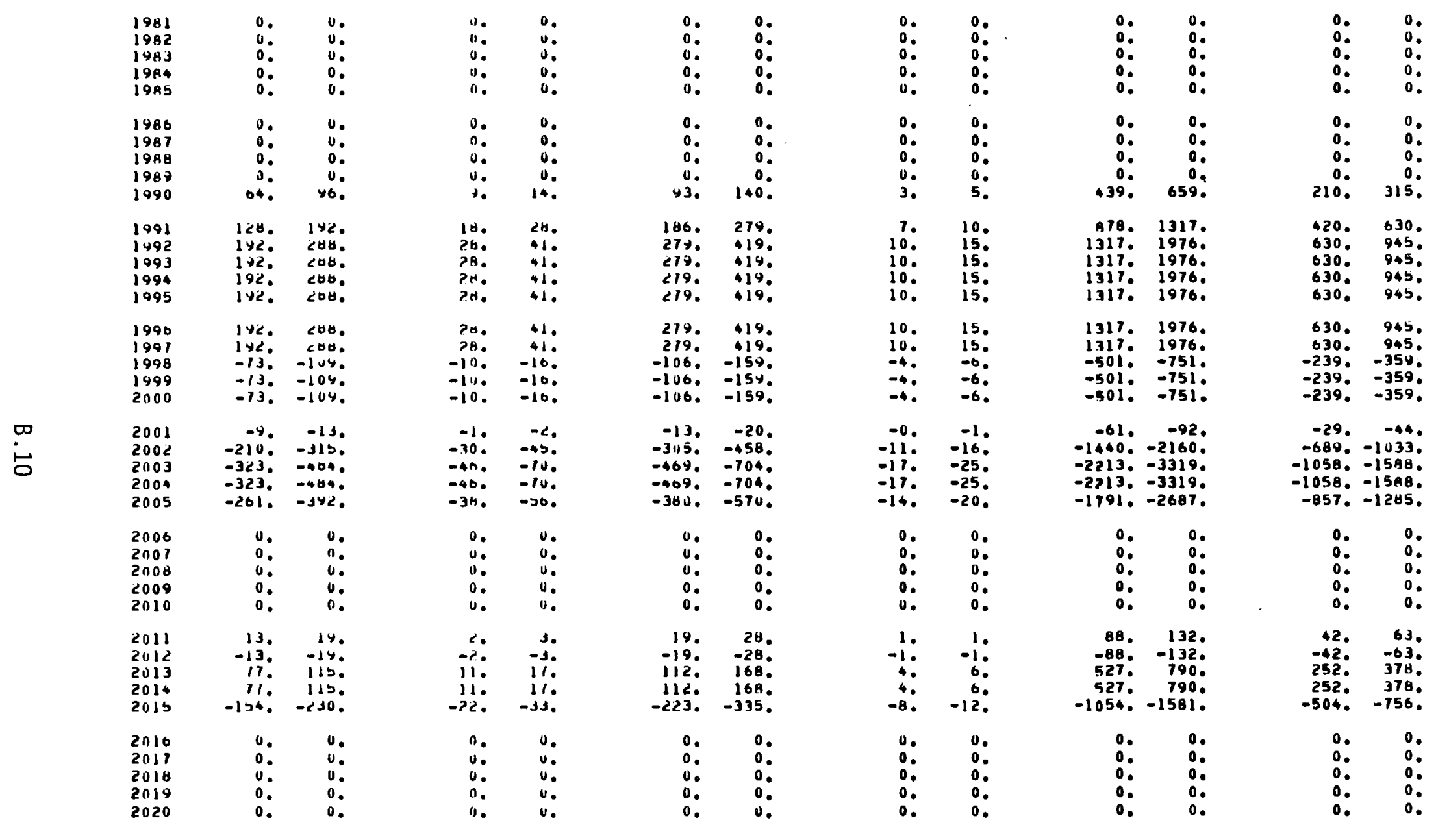


TABLE B.7. Delayed Reprocessing Scenario Summary (June 21, 1982)

\begin{tabular}{|c|c|c|c|c|c|c|c|c|c|c|}
\hline YEAK & UISCHAHGE & AR INV & MRS INV & REPROCESS & UISPOSAL & DISP INV & HL $\| R$ & HLW MFS & DISPOSAL & DISP INV \\
\hline $\begin{array}{l}1981 \\
1982 \\
1983 \\
1984 \\
1985\end{array}$ & $\begin{array}{l}1090 . \\
1231 \\
1607 \\
1744 \\
216 \%\end{array}$ & $\begin{array}{l}7871 . \\
4108 . \\
10715 . \\
12441 . \\
14014 .\end{array}$ & $\begin{array}{l}0 . \\
0 . \\
0 . \\
13 . \\
13 .\end{array}$ & $\begin{array}{l}0 . \\
0 . \\
0 . \\
0 . \\
0 .\end{array}$ & $\begin{array}{l}0 . \\
0 . \\
0 . \\
0 . \\
0 .\end{array}$ & $\begin{array}{l}0 . \\
0 . \\
0 . \\
0 . \\
0 .\end{array}$ & $\begin{array}{l}0 . \\
0 . \\
0 . \\
0 . \\
0 .\end{array}$ & $\begin{array}{l}0 . \\
0 . \\
0 . \\
0 . \\
0 .\end{array}$ & $\begin{array}{l}0 . \\
0 . \\
0 . \\
0 . \\
0 .\end{array}$ & $\begin{array}{l}0 . \\
0 . \\
0 . \\
0 . \\
0 .\end{array}$ \\
\hline $\begin{array}{l}1980 \\
1987 \\
1488 \\
1989 \\
1990\end{array}$ & $\begin{array}{l}2610 . \\
2622 . \\
2806 . \\
1223 . \\
3011 .\end{array}$ & $\begin{array}{l}17121 . \\
14567 . \\
22196 . \\
24945 . \\
21555 .\end{array}$ & $\begin{array}{l}116 . \\
292 . \\
530 . \\
1003 . \\
1463 .\end{array}$ & $\begin{array}{l}0 . \\
0 . \\
0 . \\
0 . \\
0 .\end{array}$ & $\begin{array}{l}0 . \\
0 . \\
0 . \\
0 . \\
0 .\end{array}$ & $\begin{array}{l}0 . \\
0 . \\
0 . \\
0 . \\
0 .\end{array}$ & $\begin{array}{l}0 . \\
0 . \\
0 . \\
0 .\end{array}$ & $\begin{array}{l}0 . \\
0 . \\
0 . \\
0 . \\
0 .\end{array}$ & $\begin{array}{l}0 . \\
0 . \\
0 . \\
0 . \\
0 .\end{array}$ & $\begin{array}{l}0 . \\
0 . \\
0 . \\
0 . \\
0 .\end{array}$ \\
\hline $\begin{array}{l}1991 \\
1992 \\
1993 \\
1994 \\
1995\end{array}$ & $\begin{array}{l}3078^{\circ} \\
3498 . \\
3428 . \\
3389 . \\
3574 .\end{array}$ & $\begin{array}{l}30110 . \\
12962 . \\
35121 . \\
38110 . \\
40434 .\end{array}$ & $\begin{array}{l}1487 . \\
2033 . \\
3102 . \\
4502 . \\
5552 .\end{array}$ & $\begin{array}{l}0 . \\
0 . \\
0 . \\
0 . \\
0 .\end{array}$ & $\begin{array}{l}0 . \\
0 . \\
0 . \\
0 . \\
1 .\end{array}$ & $\begin{array}{l}0 . \\
0 . \\
0 . \\
0 . \\
0 .\end{array}$ & $\begin{array}{l}0 . \\
0 . \\
0 . \\
0 . \\
0 .\end{array}$ & $\begin{array}{l}0 . \\
0 . \\
0 . \\
0 . \\
0 .\end{array}$ & $\begin{array}{l}0 . \\
0 . \\
0 . \\
0 . \\
0 .\end{array}$ & $\begin{array}{l}0 . \\
0 . \\
0 . \\
0 . \\
0 .\end{array}$ \\
\hline $\begin{array}{l}1996 \\
1997 \\
1998 \\
1997 \\
2000\end{array}$ & $\begin{array}{l}1410 . \\
3490^{\circ} \\
3814 . \\
3800 . \\
1964 .\end{array}$ & $\begin{array}{l}42404 . \\
44404 . \\
46550 . \\
44456 . \\
30333 .\end{array}$ & $\begin{array}{l}\text { lus?. } \\
0>50 . \\
0478 . \\
0478 . \\
847 \mathrm{H} .\end{array}$ & $\begin{array}{r}0 . \\
0 . \\
000 . \\
1000 .\end{array}$ & $\begin{array}{r}0 . \\
0 \% \\
1800 \\
1454 \\
108 \%\end{array}$ & $\begin{array}{r}0 . \\
0 . \\
1800 \\
3254 \\
4341 .\end{array}$ & $\begin{array}{r}0 . \\
0 . \\
0 . \\
500 \\
1000\end{array}$ & $\begin{array}{l}0 . \\
0 . \\
0 . \\
0 . \\
0 .\end{array}$ & $\begin{array}{r}0 . \\
0 . \\
0 . \\
500\end{array}$ & $\begin{array}{r}0 . \\
0 . \\
0 . \\
0 . \\
500\end{array}$ \\
\hline $\begin{array}{l}20001 \\
20002 \\
20003 \\
20004 \\
20005\end{array}$ & $\begin{array}{l}4380 . \\
4401 . \\
4669 . \\
4919 . \\
4841 .\end{array}$ & $\begin{array}{l}52328 . \\
53449 . \\
55822 . \\
27054 . \\
54554 .\end{array}$ & 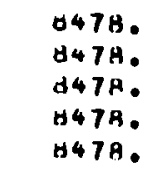 & $\begin{array}{l}1500 . \\
1500 . \\
1500 . \\
1000 . \\
1500 .\end{array}$ & $\begin{array}{l}8911^{\circ} \\
12860^{\circ} \\
11917^{\circ} \\
1388^{\circ} \\
1441^{\circ}\end{array}$ & $\begin{array}{l}5232 . \\
6518 \\
7715 \\
4302 \\
10743 .\end{array}$ & $\begin{array}{l}1500 . \\
1500 . \\
1500 . \\
1500 . \\
1500 .\end{array}$ & $\begin{array}{l}91 . \\
0 . \\
0 . \\
0 . \\
0 .\end{array}$ & $\begin{array}{l}909 . \\
1591 . \\
1500 . \\
1500 . \\
1500 .\end{array}$ & $\begin{array}{l}1409 . \\
3000 . \\
4500 . \\
6000 . \\
7500 .\end{array}$ \\
\hline $\begin{array}{l}2006 \\
2007 \\
2000 \\
2009 \\
2010\end{array}$ & $\begin{array}{l}6220 . \\
6001 . \\
6043 . \\
0537 . \\
0251 .\end{array}$ & $\begin{array}{l}01801 . \\
04591 . \\
019.36 . \\
11287 . \\
141166 .\end{array}$ & 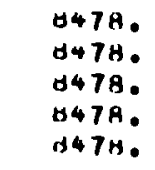 & $\begin{array}{l}1500 . \\
1500 . \\
1500 . \\
1500 . \\
2000 .\end{array}$ & $\begin{array}{l}1472 . \\
1790^{\circ} \\
11480 \\
1680^{\circ} \\
832 .\end{array}$ & $\begin{array}{l}12215 . \\
14013 . \\
15211 . \\
16896 . \\
17728 .\end{array}$ & $\begin{array}{l}1500 . \\
1500 . \\
1500 . \\
1500 . \\
2000 .\end{array}$ & $\begin{array}{l}0 . \\
0 . \\
0 . \\
0 . \\
0 .\end{array}$ & $\begin{array}{l}1500 . \\
1500 \\
1500 \\
1500 \\
1500 .\end{array}$ & $\begin{array}{r}9000 . \\
10500 \\
12000 \\
13500 \\
15000\end{array}$ \\
\hline 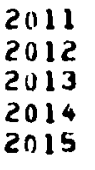 & $\begin{array}{l}6228 . \\
6381 . \\
6485 . \\
6721 . \\
1033 .\end{array}$ & $\begin{array}{l}14370 . \\
82317 . \\
06358 . \\
90962 . \\
95787 .\end{array}$ & $\begin{array}{l}4478 . \\
1052 . \\
7556 . \\
6479 . \\
4087 .\end{array}$ & $\begin{array}{l}2500 . \\
5000 . \\
3000 . \\
3000 . \\
4000 .\end{array}$ & $\begin{array}{r}04 . \\
0 . \\
0 . \\
0 . \\
0 .\end{array}$ & $\begin{array}{l}17793 . \\
17793 . \\
17793 . \\
17793 . \\
17793 .\end{array}$ & $\begin{array}{l}2500 . \\
3000 . \\
3000 . \\
3000 . \\
4000 .\end{array}$ & $\begin{array}{l}0 . \\
0 . \\
0 . \\
0 . \\
0 .\end{array}$ & $\begin{array}{l}2000 . \\
2500 . \\
3000 \\
3000 \\
3000\end{array}$ & $\begin{array}{l}17000 . \\
19500 \\
22500 \\
25500 \\
28500\end{array}$ \\
\hline $\begin{array}{l}2016 \\
2011 \\
20118 \\
2019 \\
2020\end{array}$ & $\begin{array}{l}6640 . \\
6869 . \\
1258 . \\
6642 . \\
1046 .\end{array}$ & $\begin{array}{l}100221 . \\
103033 . \\
104291 . \\
104944 . \\
10030 .\end{array}$ & $\begin{array}{r}1 \times 43 . \\
0 . \\
0 . \\
0 . \\
0 .\end{array}$ & $\begin{array}{l}5000 . \\
0000 . \\
6000 . \\
0000 . \\
7000 .\end{array}$ & $\begin{array}{l}0 . \\
0 . \\
0 . \\
0 . \\
0 .\end{array}$ & $\begin{array}{l}17793 . \\
17793 . \\
17793 . \\
17793 . \\
17793 .\end{array}$ & $\begin{array}{l}5000 . \\
6000 . \\
6000 . \\
6000 . \\
7000 .\end{array}$ & $\begin{array}{l}0 . \\
0 . \\
0 . \\
0 . \\
0 .\end{array}$ & $\begin{array}{l}6000 . \\
5000 . \\
6000 . \\
6000 . \\
6000 .\end{array}$ & $\begin{array}{l}32500 . \\
37500 \\
43500 \\
49500 \\
55500\end{array}$ \\
\hline
\end{tabular}


TABLE B.8. Delayed Reprocessing Scenario, Fuel and HLW Shipment at MRS (June 21, 1982)

\begin{tabular}{|c|c|c|c|c|c|c|c|c|c|c|}
\hline YEAH & $\begin{array}{l}\text { FUE: } \\
\text { TONNE }\end{array}$ & $\begin{array}{l}\text { STINAGE } \\
\text { EXP DISCHG }\end{array}$ & $\begin{array}{c}\text { AWH FIJEL } \\
\text { HIL } \\
\text { IUASNE }\end{array}$ & $\begin{array}{l}\text { STUKAGE } \\
\text { EXP DISCHG }\end{array}$ & $\begin{array}{l}\text { AEP PL VT } \\
\text { POOL I VV }\end{array}$ & $\begin{array}{l}\text { FUEL } \\
\text { IONNE. }\end{array}$ & $\begin{array}{l}\text { STOKAGE } \\
\text { EXP DISCHG }\end{array}$ & $\begin{array}{c}\text { PWH FUE } \\
\text { HLW } \\
\text { TONNE }\end{array}$ & $\begin{array}{l}\text { EL } \\
\text { STORAGE } \\
\text { EXP OISCHG }\end{array}$ & $\begin{array}{l}\text { REP PLNT } \\
\text { POOL INV }\end{array}$ \\
\hline $\begin{array}{l}1981 \\
1982 \\
1983 \\
1984 \\
1985\end{array}$ & $\begin{array}{l}0 . \\
0 . \\
0 . \\
0 \\
0 .\end{array}$ & $\begin{array}{ll}0 . & 1471 \\
u . & 1971 \\
u . & 1471 \\
u . & 1971 \\
0 . & 1411\end{array}$ & $\begin{array}{l}0 . \\
0 . \\
0 . \\
0 . \\
0 .\end{array}$ & $\begin{array}{ll}0 . & 1970 \\
0 . & 1971 \\
0 . & 1971 \\
0 . & 1970 \\
0 . & 1911\end{array}$ & $\begin{array}{l}0 . \\
0 . \\
0 . \\
0 . \\
0 .\end{array}$ & $\begin{array}{r}0 . \\
0 . \\
0 . \\
13 . \\
0 .\end{array}$ & $\begin{array}{l}1971 \\
1971 \\
1971 \\
1971 \\
1971\end{array}$ & $\begin{array}{l}0 . \\
0 . \\
0 . \\
0 . \\
0 .\end{array}$ & $\begin{array}{ll}0 . & 1970 \\
0 . & 1970 \\
0 . & 1970 \\
0 . & 1910 \\
0 . & 1970\end{array}$ & $\begin{array}{l}0 . \\
0 . \\
0 . \\
0 . \\
0 .\end{array}$ \\
\hline $\begin{array}{l}1980 \\
1981 \\
1988 \\
1944 \\
1990\end{array}$ & $\begin{array}{l}0 . \\
11 . \\
117 . \\
140 . \\
108 .\end{array}$ & $\begin{array}{ll}0 . & 1971 \\
4 . & 1972 \\
10 . & 1974 \\
10 . & 1916 \\
11 . & 1916\end{array}$ & $\begin{array}{l}0 . \\
0 . \\
u . \\
0 . \\
0 .\end{array}$ & $\begin{array}{ll}0 . & 1470 \\
0 . & 1970 \\
0 . & 19711 \\
0 . & 1970 \\
0 . & 1970\end{array}$ & $\begin{array}{l}0 . \\
0 . \\
0 . \\
0 . \\
0 .\end{array}$ & $\begin{array}{l}103 . \\
165 . \\
61 . \\
277 . \\
293 .\end{array}$ & $\begin{array}{ll}21 . & 1972 \\
23 \cdot & 1914 \\
21 . & 1974 \\
21 . & 1975 \\
21 . & 1976\end{array}$ & $\begin{array}{l}0 . \\
0 . \\
0 . \\
0 . \\
0 .\end{array}$ & $\begin{array}{ll}0 . & 1970 \\
0 . & 1970 \\
0 . & 1970 \\
0 . & 1970 \\
0 . & 1970\end{array}$ & $\begin{array}{l}0 . \\
0 . \\
0 . \\
0 . \\
0 .\end{array}$ \\
\hline $\begin{array}{l}1991 \\
1992 \\
1993 \\
1994 \\
1995\end{array}$ & $\begin{array}{l}331 . \\
248 . \\
234 . \\
348 . \\
353 .\end{array}$ & $\begin{array}{ll}11 . & 1971 \\
17 . & 1971 \\
160 & 1978 \\
21 . & 1978 \\
22 . & 1974\end{array}$ & $\begin{array}{l}u . \\
0 . \\
0 . \\
0 . \\
0 .\end{array}$ & $\begin{array}{ll}0 . & 1911 \\
0 . & 1911 \\
0 . & 147.1 \\
0 . & 1971 \\
0 . & 197: 1\end{array}$ & $\begin{array}{l}0 . \\
0 . \\
0 . \\
0 . \\
0 .\end{array}$ & $\begin{array}{l}193 . \\
398 . \\
435 . \\
612 . \\
498 .\end{array}$ & $\begin{array}{l}1976 \\
1977 \\
1978 \\
1979 \\
1980\end{array}$ & $\begin{array}{l}0 . \\
0 . \\
0 . \\
0 . \\
0 .\end{array}$ & $\begin{array}{l}1970 \\
1970 \\
1970 \\
1970 \\
1970\end{array}$ & $\begin{array}{l}0 . \\
0 . \\
0 . \\
0 . \\
0 .\end{array}$ \\
\hline $\begin{array}{l}1996 \\
1997 \\
1998 \\
1999 \\
2000\end{array}$ & $\begin{array}{r}518 . \\
598 . \\
-71 . \\
0 . \\
0 .\end{array}$ & $\begin{array}{cc}21 . & 1980 \\
24 . & 1981 \\
140 & 1974 \\
0 . & 1970 \\
0 . & 1970\end{array}$ & $\begin{array}{l}0 . \\
1 . \\
0 . \\
0 .\end{array}$ & $\begin{array}{ll}0 . & 19710 \\
0 . & 1971 \\
0 . & 1 \times 71 \\
0 . & 1971 \\
0 . & 1970\end{array}$ & $\begin{array}{r}0 . \\
0 . \\
0 . \\
200 \\
450\end{array}$ & $\begin{array}{r}981 . \\
900 . \\
-1 . \\
0 . \\
0 .\end{array}$ & $\begin{aligned} 29 . & 1981 \\
30 . & 1983 \\
21 . & 1971 \\
0 . & 1970 \\
0 . & 1970\end{aligned}$ & $\begin{array}{l}0 . \\
0 . \\
0 . \\
0 \\
0\end{array}$ & $\begin{array}{l}1970 \\
1970 \\
1970 \\
1970 \\
1970\end{array}$ & $\begin{array}{r}0 . \\
0 . \\
0 . \\
300 \\
550\end{array}$ \\
\hline $\begin{array}{l}2001 \\
2002 \\
2003 \\
2004 \\
2005\end{array}$ & $\begin{array}{l}0 . \\
0 . \\
0 . \\
0 . \\
0 .\end{array}$ & $\begin{array}{ll}1 . & 1970 \\
0 . & 1970 \\
0 . & 1970 \\
0 . & 1970 \\
0 . & 1970\end{array}$ & $\begin{array}{r}c . \\
-c . \\
u . \\
0 . \\
1 .\end{array}$ & $\begin{array}{ll}25 . & 1985 \\
25 . & 1985 \\
0 . & 1971 \\
0 . & 1470 \\
0 . & 1911\end{array}$ & $\begin{array}{l}550 . \\
600 . \\
600 . \\
600 . \\
600 .\end{array}$ & $\begin{array}{l}0 . \\
0 . \\
0 . \\
0 . \\
0 .\end{array}$ & $\begin{array}{ll}0 . & 1970 \\
0 . & 1970 \\
0 . & 1970 \\
0 . & 1970 \\
0 . & 1970\end{array}$ & $\begin{array}{r}88 . \\
-88 . \\
0 . \\
0 . \\
0 .\end{array}$ & $\begin{array}{rr}30 . & 1985 \\
30 . & 1985 \\
0 . & 1970 \\
0 . & 1970 \\
0 . & 1970\end{array}$ & $\begin{array}{l}950 . \\
900 . \\
900 . \\
900 . \\
900 .\end{array}$ \\
\hline $\begin{array}{l}2000 \\
2007 \\
20104 \\
2009 \\
2010\end{array}$ & $\begin{array}{l}0 . \\
u: \\
0 . \\
u: \\
0 .\end{array}$ & $\begin{array}{ll}0 . & 1910 \\
0 . & 1970 \\
0 . & 1970 \\
u . & 1910 \\
0 . & 1910\end{array}$ & $\begin{array}{l}11 . \\
0 . \\
0 . \\
0 . \\
1 .\end{array}$ & $\begin{array}{ll}0 . & 1970 \\
0 . & 1970 \\
0 . & 1970 \\
0 . & 1970 \\
0 . & 1970\end{array}$ & $\begin{array}{l}600 . \\
600 . \\
600 . \\
600 . \\
800 .\end{array}$ & $\begin{array}{l}0 . \\
0 . \\
0 . \\
0 .\end{array}$ & $\begin{array}{ll}0 . & 1970 \\
0 . & 1970 \\
0 . & 1970 \\
0 . & 1970 \\
0 . & 1970\end{array}$ & $\begin{array}{l}0 . \\
0 . \\
0 . \\
0 . \\
0 .\end{array}$ & $\begin{array}{ll}0 . & 1970 \\
0 . & 1970 \\
0 . & 1970 \\
0 . & 1970 \\
0 . & 1970\end{array}$ & $\begin{array}{l}900 . \\
900 . \\
900 . \\
900 . \\
1200 .\end{array}$ \\
\hline $\begin{array}{l}2011 \\
2012 \\
20113 \\
2014 \\
21113\end{array}$ & $\begin{array}{r}0 . \\
-184 . \\
-78 . \\
-313 . \\
-688 .\end{array}$ & $\begin{array}{ll}11 & 1970 \\
110 & 1970 \\
10 . & 1915 \\
110 & 1471 \\
11 . & 1976\end{array}$ & $\begin{array}{l}1.0 \\
0 . \\
0 . \\
1 . \\
0 .\end{array}$ & $\begin{array}{ll}0 . & 19711 \\
0 . & 19111 \\
0 . & 1471 ; \\
0 . & 197 . \\
0 . & 191 .\end{array}$ & $\begin{array}{l}1000 . \\
1200 \\
1200 \\
1200 \\
1600 .\end{array}$ & $\begin{array}{l}0 . \\
-442 . \\
-418 \\
-564 \\
-1103\end{array}$ & $\begin{array}{rr}0 . & 1970 \\
22 . & 1975 \\
21 . & 1976 \\
22 . & 1977 \\
23 . & 1979\end{array}$ & $\begin{array}{l}0 . \\
0 . \\
0 . \\
0 . \\
0 .\end{array}$ & $\begin{array}{l}1970 \\
1970 \\
1970 \\
1970 \\
1970\end{array}$ & $\begin{array}{l}1500 . \\
1800 . \\
1800 . \\
1800 . \\
2400 .\end{array}$ \\
\hline $\begin{array}{l}2016 \\
2017 \\
2018 \\
2019 \\
2020\end{array}$ & $\begin{array}{r}-963 . \\
-923 . \\
0 . \\
0 . \\
0 .\end{array}$ & $\begin{array}{cc}22 . & 1980 \\
23 . & 1981 \\
0 . & 1981 \\
0 . & 1981 \\
0 . & 1981\end{array}$ & $\begin{array}{l}\text { U. } \\
\text { u. } \\
0 . \\
0 . \\
\text { u. }\end{array}$ & $\begin{array}{ll}0 . & 1971 \\
0 . & 1911 \\
0 . & 1911 \\
0 . & 1911 \\
0 . & 1910\end{array}$ & $\begin{array}{l}2000 . \\
24000 \\
24000 \\
2400 . \\
2800 .\end{array}$ & $\begin{array}{r}-1781 . \\
-1019 . \\
0 . \\
0 .\end{array}$ & $\begin{aligned} 27 . & 1981 \\
30 . & 1983 \\
0 . & 1983 \\
0 . & 1983 \\
0 . & 1983\end{aligned}$ & $\begin{array}{l}0 . \\
0 . \\
0 . \\
0 . \\
0 .\end{array}$ & $\begin{array}{ll}0 . & 1970 \\
0 . & 1970 \\
0 . & 1970 \\
0 . & 1970 \\
0 . & 1970\end{array}$ & $\begin{array}{l}3000 \\
3600 \\
3600 \\
3600 \\
4200\end{array}$ \\
\hline
\end{tabular}




\begin{tabular}{|c|c|c|c|c|c|c|c|c|c|c|}
\hline $\begin{array}{l}.00099 \\
.00015 \\
000264 \\
00414 \\
.0096 E\end{array}$ & $\begin{array}{l}.0006 \\
.0081 \\
00081 \\
.0081 \\
.0099\end{array}$ & $\begin{array}{l}0008 \$ \\
00056 \$ \\
0006 \$ 5 \\
000945 \\
00045\end{array}$ & $\begin{array}{l}00522 \\
.00527 \\
000081 \\
000081 \\
.00081\end{array}$ & $\begin{array}{l}\because 0 \\
\because n \\
: 0 \\
0 \\
0\end{array}$ & $\begin{array}{l}\because 0 \\
\because n \\
: 0 \\
0 \\
0\end{array}$ & 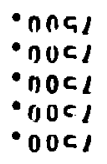 & $\begin{array}{l}0 u \\
: u \\
00 \\
\cdot u \\
\cdot u\end{array}$ & 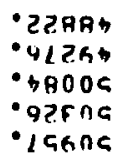 & 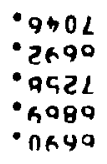 & $\begin{array}{l}0202 \\
9102 \\
9102 \\
9102 \\
1102 \\
91102\end{array}$ \\
\hline $\begin{array}{l}.00012 \\
.00 \$ 02 \\
.00951 \\
.00801 \\
0021\end{array}$ & $\begin{array}{l}.0099 \\
.0089 \\
0084 \\
.0098 \\
.0081\end{array}$ & $\begin{array}{l}.000 \angle 5 \\
.00409 \\
00065 \\
00285 \\
00055\end{array}$ & $\begin{array}{l}\text {.0005I } \\
\text {.0050I } \\
\text { OONSOI } \\
\text { O0OSL } \\
\text {.0059 }\end{array}$ & $\begin{array}{l}\because 0 \\
\because 0 \\
\because 0 \\
: 0 \\
0\end{array}$ & $\begin{array}{l}\cdot n \\
: n \\
: 0 \\
: n \\
n\end{array}$ & 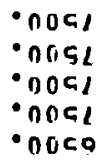 & $\begin{array}{l}\cdot 0 \\
\cdot 0 \\
\cdot u \\
\cdot u \\
\cdot u\end{array}$ & 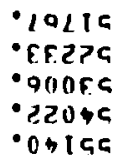 & 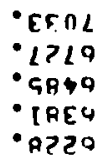 & $\begin{array}{l}\text { S1 } 102 \\
1102 \\
8102 \\
2102 \\
1102\end{array}$ \\
\hline $\begin{array}{l}.0045 \\
.009 E \\
0001 \\
00 \\
0\end{array}$ & $\begin{array}{l}\cdot 0081 \\
0001 \\
0081 \\
0081 \\
0 \\
0 \\
0\end{array}$ & $\begin{array}{l}.0010 S \\
.0065 \% \\
.0021 \% \\
\text { OOSLE } \\
\text { OOSZE }\end{array}$ & $\begin{array}{l}.0001 \\
00009 \\
0009 \\
0009 \\
00005\end{array}$ & $\begin{array}{l}\because 0 \\
\because 0 \\
\because 0 \\
0 \\
0\end{array}$ & $\begin{array}{l}: n \\
: 0 \\
: n \\
0 \\
0 \\
n\end{array}$ & 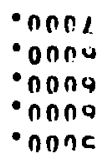 & $\begin{array}{l}\cdot 0 \\
: 0 \\
: 0 \\
0 \\
0 \\
0\end{array}$ & 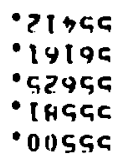 & 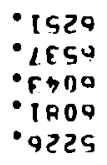 & $\begin{array}{l}0102 \\
6002 \\
9002 \\
1002 \\
9002\end{array}$ \\
\hline $\begin{array}{l}\because 0 \\
\because 0 \\
\because 0 \\
\because 0 \\
\because 0\end{array}$ & $\begin{array}{l}0 \\
0 \\
0 \\
0 \\
0 \\
0 \\
0\end{array}$ & $\begin{array}{l}\text { O0 0582 } \\
\text { 00552 } \\
.00522 \\
00561 \\
00011\end{array}$ & $\begin{array}{l}.0004 \\
.000 E \\
.000 E \\
.000 E \\
.005 ?\end{array}$ & $\begin{array}{l}\cdot 0 \\
: 0 \\
\bullet 0 \\
0 \\
0 \\
0\end{array}$ & $\begin{array}{l}\because 0 \\
\because 0 \\
\because 0 \\
0 \\
0\end{array}$ & 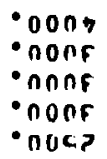 & $\begin{array}{l}\because 0 \\
\because 0 \\
\because n \\
\because 0 \\
0\end{array}$ & 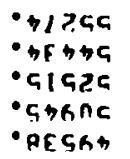 & 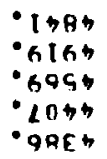 & $\begin{array}{l}5002 \\
7002 \\
5002 \\
2002 \\
1002\end{array}$ \\
\hline $\begin{array}{l}\because 0 \\
\because 0 \\
\because 0 \\
\because 0 \\
.0\end{array}$ & $\begin{array}{l}: 0 \\
0 \\
0 \\
0 \\
0 \\
0\end{array}$ & $\begin{array}{l}\text {.000SI } \\
\text { OOOSEI } \\
.00021 \\
.00501 \\
.0006\end{array}$ & $\begin{array}{l}.0002 \\
.0051 \\
.0051 \\
.0051 \\
.0051\end{array}$ & $\begin{array}{l}\because 0 \\
\because 0 \\
\because 0 \\
\because 0\end{array}$ & $\begin{array}{l}\because 0 \\
\because 0 \\
\because n \\
\because n \\
0\end{array}$ & $\begin{array}{l}\cdot 0 n 02 \\
000<1 \\
0 n 0<1 \\
00 n<1 \\
0001\end{array}$ & $\begin{array}{l}\cdot 0 \\
\cdot 0 \\
-11 \\
\cdot 0 \\
\cdot 0\end{array}$ & 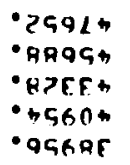 & 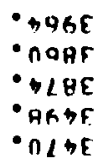 & $\begin{array}{l}0002 \\
4661 \\
9661 \\
1661 \\
9661\end{array}$ \\
\hline $\begin{array}{l}\because 0 \\
\because 0 \\
\because 0 \\
\because 0 \\
0\end{array}$ & $\begin{array}{l}\because 0 \\
0 \\
0 \\
0 \\
0 \\
0\end{array}$ & $\begin{array}{l}\text { OOSL } \\
.0009 \\
.005 \% \\
.0008 \\
.0051\end{array}$ & $\begin{array}{l}\text { OOSI } \\
\text { ONSI } \\
\text { ONOSI } \\
\text { OOSI } \\
\text { OOSI }\end{array}$ & 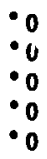 & $\begin{array}{l}\bullet 0 \\
\because n \\
: n \\
: n \\
0\end{array}$ & 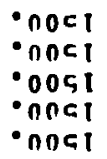 & $\begin{array}{l}\bullet u \\
\bullet 0 \\
\bullet 0 \\
\bullet u \\
\cdot u\end{array}$ & 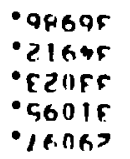 & 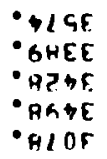 & $\begin{array}{l}5661 \\
7661 \\
5601 \\
2661 \\
1661\end{array}$ \\
\hline $\begin{array}{l}\because 0 \\
\because 0 \\
\because 0 \\
\because 0 \\
0\end{array}$ & $\begin{array}{l}0 \\
0 \\
0 \\
0 \\
0 \\
0 \\
0\end{array}$ & $\begin{array}{l}: 005 \\
: 0 \\
0 \\
0 \\
0 \\
0\end{array}$ & $\begin{array}{l}\because 0001 \\
\because 005 \\
: 0 \\
0 \\
0 \\
0\end{array}$ & $\begin{array}{l}: 0 \\
\because 0 \\
0 \\
\because 0 \\
0\end{array}$ & $\begin{array}{l}\because 0 \\
: 0 \\
: 0 \\
0 \\
0 \\
0\end{array}$ & $\begin{array}{l}\because \begin{array}{ll}n 001 \\
000 \\
n 0 \\
\because n \\
0 \\
0\end{array} \\
0\end{array}$ & 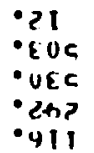 & 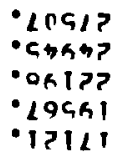 & $\begin{array}{l}-110 r \\
-8225 \\
0482 \\
02592 \\
0197\end{array}$ & $\begin{array}{l}0661 \\
6861 \\
9861 \\
1861 \\
9861\end{array}$ \\
\hline $\begin{array}{l}\because 0 \\
\because 0 \\
\because 0 \\
\because 0 \\
0\end{array}$ & $\begin{array}{l}: 0 \\
: 0 \\
: 0 \\
: 0 \\
: 0\end{array}$ & $\begin{array}{l}: 0 \\
0 \\
0 \\
0 \\
0 \\
0\end{array}$ & $\begin{array}{l}\because 0 \\
: 0 \\
0 \\
0 \\
0 \\
0\end{array}$ & $\begin{array}{l}\bullet 0 \\
\because 0 \\
\because 0 \\
\because 0 \\
0\end{array}$ & $\begin{array}{l}0 \\
\because n \\
0 n \\
n \\
n\end{array}$ & $\begin{array}{l}\cdot 11 \\
\cdot n \\
0 n \\
0 n \\
0 \\
n\end{array}$ & $\begin{array}{l}\cdot E 1 \\
\cdot E 1 \\
\bullet 0 \\
\cdot 0 \\
\cdot 0 \\
0\end{array}$ & 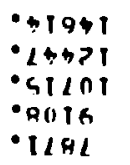 & 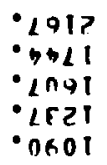 & $\begin{array}{l}5861 \\
7861 \\
5861 \\
2861 \\
\mid 861\end{array}$ \\
\hline
\end{tabular}


TABLE B.9 (contd)

\begin{tabular}{|c|c|c|c|c|c|c|c|c|c|c|c|c|}
\hline YEAK & UISCHARGE & AK INV & MHS & INV & HEPROLESS & UISPOSAL & DISP & INV & HLW A $\mathrm{K}$ & HLW MRS & OISPOSAL & DISP INV \\
\hline $\begin{array}{l}2021 \\
2022 \\
2023 \\
2024 \\
2025\end{array}$ & $\begin{array}{l}7000 . \\
7000 . \\
1000 . \\
1000 . \\
1500 .\end{array}$ & $\begin{array}{l}48322 . \\
41822 . \\
41322 . \\
46822 . \\
46822 .\end{array}$ & & $\begin{array}{l}0 . \\
0 . \\
0 . \\
0 . \\
0 .\end{array}$ & $\begin{array}{l}1200 . \\
1500 . \\
1500 . \\
1500 . \\
1500 .\end{array}$ & $\begin{array}{l}0 . \\
0 . \\
0 . \\
0 . \\
0 .\end{array}$ & & $\begin{array}{l}0 . \\
0 . \\
0 . \\
0 . \\
0 .\end{array}$ & $\begin{array}{l}25500 . \\
25500 . \\
25500 . \\
25500 . \\
25500 .\end{array}$ & $\begin{array}{l}43500 . \\
42000 . \\
40500 . \\
39000 \\
35700 .\end{array}$ & $\begin{array}{l}9000 . \\
9000 \\
9000 \\
9000 \\
10800\end{array}$ & $\begin{array}{r}15000 \\
84000 \\
93000 \\
102000 \\
112800\end{array}$ \\
\hline $\begin{array}{l}2026 \\
2027 \\
2028 \\
2029 \\
2030\end{array}$ & $\begin{array}{l}1500 . \\
7500 . \\
1500 . \\
7500 . \\
1500 .\end{array}$ & $\begin{array}{l}40022 . \\
46022 . \\
40022 . \\
40 \forall 22 . \\
46022 .\end{array}$ & & $\begin{array}{l}0 . \\
0 . \\
0 . \\
0 .\end{array}$ & $\begin{array}{l}\text { 1 } 200 . \\
1500 . \\
1500 . \\
\text { 1200. } \\
\text { 1 } 200 .\end{array}$ & $\begin{array}{l}0 . \\
0 . \\
0 . \\
0 . \\
0 .\end{array}$ & & $\begin{array}{l}0 . \\
0 . \\
0 . \\
0 . \\
0 .\end{array}$ & $\begin{array}{l}25500 \text {. } \\
30000 \\
30000 \\
30000 \\
30000 .\end{array}$ & $\begin{array}{l}32400 . \\
24600 \\
21300 \\
18000 \\
13500 .\end{array}$ & $\begin{array}{l}10800 . \\
10800 . \\
10800 \\
10800 \\
12000\end{array}$ & $\begin{array}{l}123600 \\
134400 \\
145200 \\
156000 \\
168000\end{array}$ \\
\hline $\begin{array}{l}2031 \\
2032 \\
2033 \\
2034 \\
2035\end{array}$ & $\begin{array}{l}7500 . \\
1500 . \\
7500 . \\
1500 . \\
1500 .\end{array}$ & $\begin{array}{l}46022 . \\
46022 . \\
46022 . \\
46022 . \\
46027 .\end{array}$ & & $\begin{array}{l}0 . \\
0 . \\
0 . \\
0 . \\
0 .\end{array}$ & $\begin{array}{l}\text { 1500. } \\
1500 . \\
1500 . \\
1500 . \\
1500 .\end{array}$ & $\begin{array}{l}0 . \\
0 . \\
0 . \\
0 . \\
0 .\end{array}$ & & $\begin{array}{l}0 . \\
0 . \\
0 . \\
0 . \\
0 .\end{array}$ & $\begin{array}{l}30000 . \\
30000 \\
30000 \\
30000 \\
30000 .\end{array}$ & $\begin{array}{r}9000 . \\
4500 . \\
0 . \\
0 . \\
0 .\end{array}$ & $\begin{array}{r}12000 . \\
12000^{\circ} \\
12000^{\circ} \\
7500^{\circ} \\
7500^{\circ}\end{array}$ & $\begin{array}{l}180000 . \\
192000 \\
204000 \\
211500 \\
219000\end{array}$ \\
\hline $\begin{array}{l}2036 \\
2031 \\
2038 \\
2039 \\
2040\end{array}$ & $\begin{array}{l}1500 . \\
7500 . \\
1500 . \\
7500 . \\
7500 .\end{array}$ & $\begin{array}{l}46822 . \\
46822 . \\
46022 . \\
46822 . \\
40622 .\end{array}$ & & $\begin{array}{l}0 . \\
0 . \\
0 . \\
0 .\end{array}$ & $\begin{array}{l}1500 . \\
1500 . \\
7500 . \\
7500 . \\
1000 .\end{array}$ & $\begin{array}{l}0 . \\
0 . \\
0 . \\
0 . \\
0 .\end{array}$ & & $\begin{array}{l}0 . \\
0 . \\
0 . \\
0 . \\
0 .\end{array}$ & $\begin{array}{l}30000 . \\
30000 . \\
30000 . \\
30000 . \\
30000 .\end{array}$ & $\begin{array}{l}0 . \\
0 . \\
0 . \\
0 . \\
0 .\end{array}$ & $\begin{array}{l}7500 . \\
7500 . \\
7500 . \\
7500 . \\
7500 .\end{array}$ & $\begin{array}{l}226500 \\
234000 \\
241500 \\
249000 \\
256500\end{array}$ \\
\hline
\end{tabular}


TABLE B.10. Delayed Disposal Scenario, Fuel and HLW Shipments at MRS (June 21, 1982)

\begin{tabular}{|c|c|c|c|c|c|c|c|c|c|c|}
\hline YEAH & $\begin{array}{c}\text { FUEI } \\
\text { IINNEE }\end{array}$ & $\begin{array}{l}\text { STUKAGE } \\
\text { EXP UISCHG }\end{array}$ & $\begin{array}{l}\text { GWK FUIEL } \\
\text { HLW" } \\
\text { IUNNF. }\end{array}$ & $\begin{array}{l}\text { STORAGE } \\
\text { EXP OISCHG }\end{array}$ & $\begin{array}{l}\text { REP PLNT } \\
\text { POOL I NV }\end{array}$ & $\begin{array}{l}\text { FIJEL } \\
\text { TONNE }\end{array}$ & $\begin{array}{l}\text { STORAGE } \\
\text { EXP DISCHG }\end{array}$ & $\begin{array}{c}\text { PWR FU } \\
\text { HLW } \\
\text { TONNE }\end{array}$ & $\begin{array}{l}\text { EL } \\
\text { STORAGE } \\
\text { EXP DISCHG }\end{array}$ & $\begin{array}{l}\text { REP PLNT } \\
\text { POOL INV }\end{array}$ \\
\hline $\begin{array}{l}1981 \\
1982 \\
1983 \\
1984 \\
1985\end{array}$ & $\begin{array}{l}0 . \\
0 . \\
0 . \\
0 . \\
0 .\end{array}$ & $\begin{array}{ll}0 . & 1471 \\
0 . & 1471 \\
0 . & 1411 \\
0 . & 1471 \\
0 . & 1411\end{array}$ & $\begin{array}{l}0 . \\
u . \\
0 . \\
0 . \\
1 .\end{array}$ & $\begin{array}{ll}0 . & 1970 \\
0 . & 1911 \\
0 . & 1910 \\
0 . & 1910 \\
0 . & 1970\end{array}$ & $\begin{array}{l}\text { u. } \\
\text { u. } \\
\text { u. } \\
\text { u. }\end{array}$ & $\begin{array}{l}0 . \\
0 . \\
0 . \\
13\end{array}$ & $\begin{array}{l}1971 \\
1971 \\
1971 \\
1971 \\
1971\end{array}$ & $\begin{array}{l}0 . \\
0 . \\
0 . \\
0 . \\
0 .\end{array}$ & $\begin{array}{ll}0 . & 1970 \\
0 . & 1970 \\
0 . & 1970 \\
0 . & 1970 \\
0 . & 1970\end{array}$ & $\begin{array}{l}0 . \\
0 . \\
0 . \\
0 . \\
0 .\end{array}$ \\
\hline $\begin{array}{l}1986 \\
1987 \\
1988 \\
1949 \\
1990\end{array}$ & $\begin{array}{r}0 . \\
110 \\
110 \\
-1430\end{array}$ & $\begin{array}{cc}0 . & 1971 \\
y . & 1912 \\
12 . & 1974 \\
y . & 1972 \\
150 & 1974\end{array}$ & $\begin{array}{l}11 . \\
11 . \\
11 . \\
200 .\end{array}$ & $\begin{array}{ll}0 . & 1911 \\
0 . & 1971 \\
0 . & 1971 \\
0 . & 1910 \\
16 . & 1910\end{array}$ & $\begin{array}{l}0 . \\
0 . \\
0 . \\
200 . \\
400 .\end{array}$ & $\begin{array}{r}103 . \\
165 . \\
61 . \\
-22 . \\
-307 .\end{array}$ & $\begin{array}{l}1472 \\
1974 \\
1974 \\
1972 \\
1974\end{array}$ & $\begin{array}{l}0 . \\
0 . \\
0 . \\
300 .\end{array}$ & $\begin{aligned} 0 . & 1970 \\
0 . & 1970 \\
0 . & 1970 \\
0 . & 1970 \\
21 . & 1975\end{aligned}$ & $\begin{array}{l}0 . \\
0 . \\
0 . \\
600 .\end{array}$ \\
\hline $\begin{array}{l}1991 \\
1992 \\
1993 \\
1994 \\
1995\end{array}$ & $\begin{array}{l}0 . \\
0 . \\
0 . \\
0 .\end{array}$ & $\begin{array}{ll}u . & 1974 \\
u . & 1914 \\
u . & 1974 \\
3 . & 1914 \\
0 . & 1974\end{array}$ & $\begin{array}{l}400 . \\
600 . \\
\text { 60u. } \\
600 . \\
\text { nou. }\end{array}$ & $\begin{array}{ll}16 . & 1971 \\
11 . & 1911 \\
20 . & 1971 \\
22 . & 1981 \\
23 . & 1981\end{array}$ & $\begin{array}{l}600 . \\
600 . \\
600 . \\
600 . \\
600 .\end{array}$ & $\begin{array}{r}-12 . \\
0 . \\
0 . \\
0 .\end{array}$ & $\begin{aligned} 21 . & 1974 \\
0 . & 1914 \\
0 . & 1974 \\
0 . & 1974 \\
0 . & 1974\end{aligned}$ & $\begin{array}{l}600 . \\
900 . \\
900 . \\
900 . \\
900 .\end{array}$ & $\begin{array}{l}1976 \\
1978 \\
1979 \\
1980 \\
1981\end{array}$ & $\begin{array}{l}900 . \\
900 . \\
900 . \\
900 \\
900 .\end{array}$ \\
\hline $\begin{array}{l}1996 \\
1997 \\
1994 \\
1999 \\
2000\end{array}$ & $\begin{array}{l}0 . \\
0 . \\
0 . \\
0 . \\
0 .\end{array}$ & $\begin{array}{ll}\text { U. } & 1974 \\
\text { u. } & 1974 \\
11 . & 1914 \\
\text { U. } & 1914 \\
\text { i. } & 1914\end{array}$ & $\begin{array}{l}600 . \\
600 . \\
600 . \\
600 . \\
600 .\end{array}$ & $\begin{array}{ll}25 . & 1982 \\
25 . & 1983 \\
25 . & 1984 \\
25 . & 1985 \\
25 . & 1980\end{array}$ & $\begin{array}{l}600 . \\
600 . \\
600 . \\
600 . \\
600 .\end{array}$ & $\begin{array}{l}0 . \\
0 . \\
0 . \\
0 . \\
0 .\end{array}$ & $\begin{array}{ll}0 . & 1974 \\
0 . & 1974 \\
0 . & 1974 \\
0 . & 1974 \\
0 . & 1974\end{array}$ & $\begin{array}{l}900 . \\
900 . \\
900 . \\
900 . \\
900 .\end{array}$ & $\begin{array}{ll}30 \cdot & 1983 \\
30 & 1983 \\
30 & 1984 \\
30: & 1985 \\
30 & 1986\end{array}$ & $\begin{array}{l}900 . \\
900 . \\
900 . \\
900 . \\
1200 .\end{array}$ \\
\hline $\begin{array}{l}2001 \\
2002 \\
2003 \\
2004 \\
2005\end{array}$ & $\begin{array}{l}u . \\
0 . \\
0 . \\
i . \\
u .\end{array}$ & $\begin{array}{ll}0 . & 1974 \\
1 . & 1974 \\
0 . & 1974 \\
0 . & 1474 \\
0 . & 1774\end{array}$ & $\begin{array}{l}\text { AnO. } \\
1001 . \\
1200 . \\
1200 . \\
1200 .\end{array}$ & $\begin{array}{ll}2 b . & 1981 \\
2 b . & 1984 \\
2 b . & 1944 \\
25 . & 1940 \\
25 . & 1941\end{array}$ & $\begin{array}{l}1000 . \\
1200 \% \\
1200 . \\
1200 . \\
1600 .\end{array}$ & $\begin{array}{l}0 . \\
0 . \\
0 . \\
0 . \\
0 .\end{array}$ & $\begin{array}{l}1974 \\
1974 \\
1974 \\
1974 \\
1974\end{array}$ & $\begin{array}{l}1200 . \\
1500 . \\
1800 \\
1800 . \\
1800 .\end{array}$ & $\begin{array}{ll}30 . & 1986 \\
30 . & 1987 \\
30 \circ & 1988 \\
30 . & 1989 \\
30 . & 1990\end{array}$ & $\begin{array}{l}1500 . \\
1800 \\
1800 \\
1800 \\
2400 .\end{array}$ \\
\hline $\begin{array}{l}2006 \\
2001 \\
2008 \\
2004 \\
2010\end{array}$ & $\begin{array}{l}0 . \\
0 . \\
0 . \\
0 . \\
0 .\end{array}$ & $\begin{array}{ll}u . & 1974 \\
0 . & 1974 \\
i . & 1974 \\
0 . & 1974 \\
0 . & 1974\end{array}$ & $\begin{array}{l}1600 . \\
2000 . \\
1680 . \\
1681.0 \\
1601 .\end{array}$ & $\begin{array}{ll}25 . & 1941 \\
25 . & 1994 \\
25 . & 1995 \\
25 . & 1991 \\
25 . & 1944\end{array}$ & $\begin{array}{l}2000 . \\
2400 . \\
2400 . \\
2400 . \\
2000 .\end{array}$ & $\begin{array}{l}0 . \\
0 . \\
0 . \\
0 . \\
0 .\end{array}$ & $\begin{array}{ll}0 . & 1974 \\
0 . & 1974 \\
0 . & 1974 \\
0 . & 1974 \\
0 . & 1974\end{array}$ & $\begin{array}{l}2400 . \\
3000 . \\
2520 . \\
2520 . \\
2520 .\end{array}$ & $\begin{array}{ll}33 . & 1991 \\
35 . & 1993 \\
35 . & 1994 \\
35 . & 1996 \\
35 . & 1998\end{array}$ & $\begin{array}{l}3000 \\
3600 \\
3600 \\
3600 \\
4200 .\end{array}$ \\
\hline $\begin{array}{l}2011 \\
2012 \\
2013 \\
2014 \\
2015\end{array}$ & $\begin{array}{l}0 . \\
0 . \\
0 . \\
0 . \\
0 .\end{array}$ & $\begin{array}{ll}\text { u. } & 1914 \\
\text { J. } & 1914 \\
u . & 1914 \\
u . & 1974 \\
\text { u. } & 1914\end{array}$ & $\begin{array}{r}\angle 080 . \\
1160 . \\
-1920 . \\
10810 \\
3 \times 0 .\end{array}$ & $\begin{array}{ll}25 . & 2001 \\
25 . & 2002 \\
18 . & 19 H 11 \\
25 . & 2004 \\
25 . & 2005\end{array}$ & $\begin{array}{l}2600 . \\
3000 . \\
6000 . \\
6000 . \\
6000 .\end{array}$ & $\begin{array}{l}0 . \\
0 . \\
0 . \\
0 .\end{array}$ & $\begin{array}{ll}0 . & 1974 \\
0 . & 1974 \\
0 . & 1974 \\
0 . & 1974 \\
0 . & 1974\end{array}$ & $\begin{array}{r}3120 . \\
1740 \\
1620 \\
1620 \\
-3960 .\end{array}$ & $\begin{array}{ll}35 . & 1999 \\
35 . & 2001 \\
35 . & 2003 \\
35 . & 2004 \\
24 . & 1981\end{array}$ & $\begin{array}{l}3900 . \\
4500 . \\
4500 . \\
4500 . \\
9000 .\end{array}$ \\
\hline $\begin{array}{l}21116 \\
2017 \\
2019 \\
2019 \\
2020\end{array}$ & $\begin{array}{l}0 . \\
0 . \\
0 . \\
0 . \\
0 .\end{array}$ & $\begin{array}{ll}1 . & 1974 \\
\text { U. } & 1974 \\
u . & 1974 \\
\text { u. } & 1974 \\
0 . & 1974\end{array}$ & $\begin{array}{l}-26411 . \\
-121 . \\
-121 . \\
-120 . \\
-600 .\end{array}$ & $\begin{array}{ll}24 . & 1984 \\
25 . & 1984 \\
25 . & 1984 \\
25 . & 1985 \\
25 . & 1986\end{array}$ & $\begin{array}{l}9000 . \\
9000 . \\
9000 . \\
9000 . \\
9000 .\end{array}$ & $\begin{array}{l}0 . \\
0 . \\
0 . \\
0 .\end{array}$ & $\begin{array}{ll}0 . & 1974 \\
0 . & 1974 \\
0 . & 1974 \\
0 . & 1974 \\
0 . & 1974\end{array}$ & $\begin{array}{r}540 . \\
-180 . \\
-180 . \\
-4680 . \\
-900 .\end{array}$ & $\begin{array}{l}2006 \\
1981 \\
1981 \\
1986 \\
1986\end{array}$ & $\begin{array}{l}9000 . \\
9000 . \\
9000 . \\
13500 . \\
13500 .\end{array}$ \\
\hline
\end{tabular}


TABLE B.10 (contd)

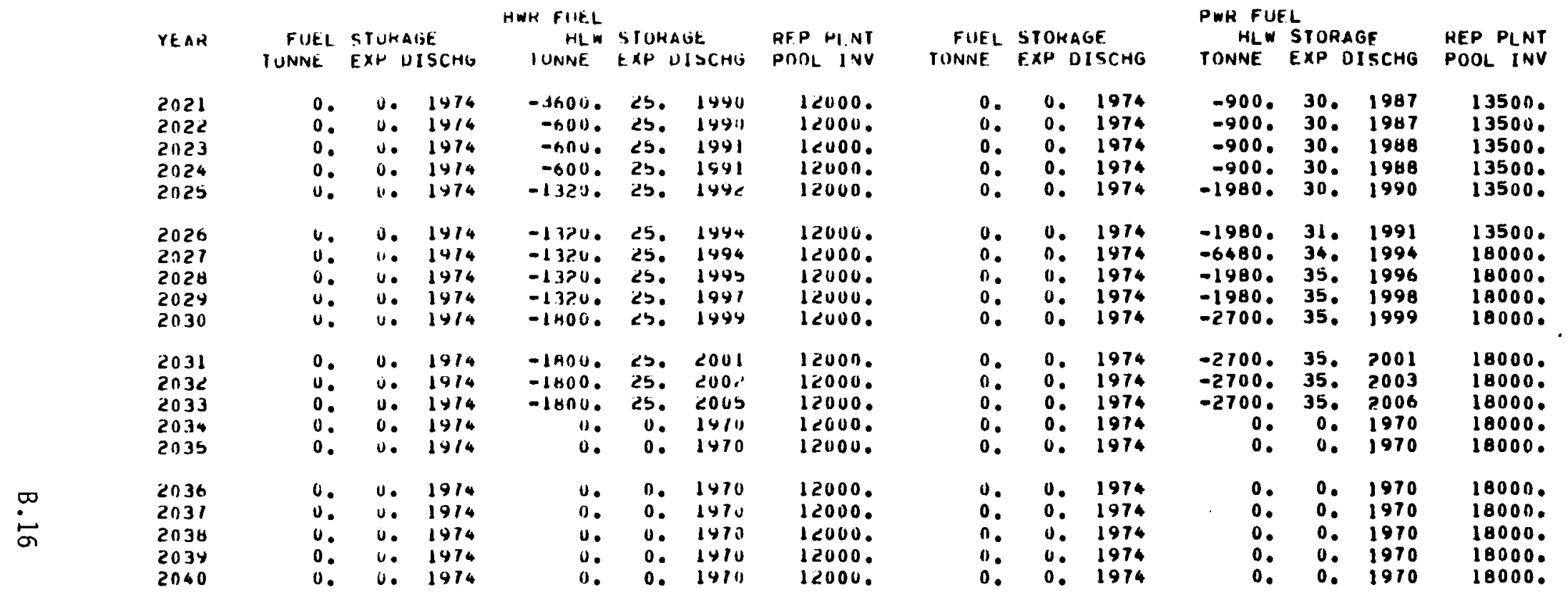


TABLE B.11. Delayed Disposal Scenario, Number of TRU Packages Handled at MRS (June 21, 1982)

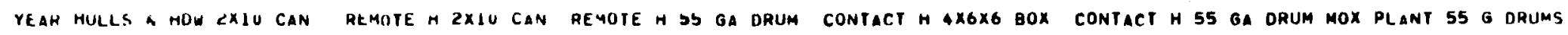

\begin{tabular}{|c|c|c|c|c|c|c|c|c|c|c|c|c|}
\hline $\begin{array}{l}19 A 1 \\
19 A 2 \\
19 A 3 \\
1984 \\
1985\end{array}$ & $\begin{array}{l}0 . \\
0: \\
0: \\
0 .\end{array}$ & $\begin{array}{l}0 . \\
0 . \\
0 . \\
0 . \\
0 .\end{array}$ & $\begin{array}{l}10 . \\
0 . \\
10 . \\
0 .\end{array}$ & $\begin{array}{l}0 . \\
0 . \\
0 . \\
0 . \\
0 .\end{array}$ & $\begin{array}{l}0 . \\
u: \\
0 . \\
0 . \\
1 .\end{array}$ & $\begin{array}{l}0 . \\
0: \\
0: \\
0 .\end{array}$ & $\begin{array}{l}0 . \\
0 . \\
0 . \\
0 . \\
0 .\end{array}$ & $\begin{array}{l}0 . \\
0: \\
0: \\
0 . \\
0 .\end{array}$ & $\begin{array}{l}0 . \\
0: \\
0 . \\
0 .\end{array}$ & $\begin{array}{l}0 . \\
0 . \\
0 . \\
0 .\end{array}$ & $\begin{array}{l}0 . \\
0 . \\
0 . \\
0 .\end{array}$ & $\begin{array}{l}0 . \\
0 . \\
0 . \\
0 .\end{array}$ \\
\hline $\begin{array}{l}1986 \\
1987 \\
1988 \\
1989 \\
1490\end{array}$ & $\begin{array}{l}0 . \\
0 . \\
0 . \\
0.0 \\
0.0\end{array}$ & $\begin{array}{l}0 . \\
0 . \\
0 . \\
0 . \\
\text { yo. }\end{array}$ & $\begin{array}{l}0 . \\
0 . \\
0 . \\
0 . \\
\text { y. }\end{array}$ & $\begin{array}{l}1.0 \\
0 . \\
u . \\
14 .\end{array}$ & $\begin{array}{l}0 . \\
0 . \\
0 . \\
0.0 \\
0.0\end{array}$ & $\begin{array}{r}0 . \\
0 . \\
0 . \\
0 .\end{array}$ & $\begin{array}{l}0 . \\
0 . \\
0 . \\
0 . \\
3 .\end{array}$ & $\begin{array}{l}0 . \\
0 . \\
0 . \\
0 . \\
5 .\end{array}$ & $\begin{array}{r}0 . \\
0 . \\
0 . \\
0 \\
49\end{array}$ & $\begin{array}{r}0 . \\
0 . \\
0 . \\
0 . \\
659\end{array}$ & $\begin{array}{r}0 \\
0 \\
0 \\
0 \\
210\end{array}$ & $\begin{array}{r}0 . \\
0 . \\
0 . \\
315 .\end{array}$ \\
\hline $\begin{array}{l}1991 \\
1992 \\
1993 \\
1494 \\
1995\end{array}$ & $\begin{array}{l}128 . \\
142 . \\
1920 \\
142 . \\
142 .\end{array}$ & $\begin{array}{l}1 y<. \\
2 \forall 0 . \\
608 . \\
<\forall 8 . \\
200 .\end{array}$ & 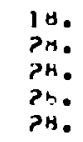 & $\begin{array}{l}20 . \\
41 . \\
41 . \\
41 .\end{array}$ & $\begin{array}{l}186 . \\
279 . \\
279 . \\
279 . \\
279 .\end{array}$ & $\begin{array}{l}279 . \\
419 . \\
419 . \\
419 . \\
419 .\end{array}$ & $\begin{array}{l}7 . \\
10 . \\
10 . \\
10 . \\
10 .\end{array}$ & $\begin{array}{l}10 . \\
15 . \\
15 . \\
15 . \\
15 .\end{array}$ & $\begin{aligned} 878 . \\
1317 . \\
1317 . \\
1317 . \\
1317 .\end{aligned}$ & $\begin{array}{l}1317 . \\
1976 . \\
1976 . \\
1976 . \\
1976 .\end{array}$ & $\begin{array}{l}420 . \\
630 . \\
630 \\
630 . \\
630 .\end{array}$ & $\begin{array}{l}630 . \\
945 . \\
945 . \\
945 . \\
945 .\end{array}$ \\
\hline $\begin{array}{l}1990 \\
1991 \\
1990 \\
1990 \\
2000\end{array}$ & $\begin{array}{l}142 . \\
142 . \\
192 . \\
192 . \\
142 .\end{array}$ & 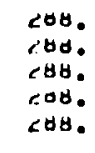 & $\begin{array}{l}20 . \\
26 . \\
24 . \\
20 . \\
24 .\end{array}$ & $\begin{array}{l}+10 \\
410 \\
410 \\
410\end{array}$ & $\begin{array}{l}279 . \\
279 . \\
279 . \\
279 . \\
279 .\end{array}$ & $\begin{array}{l}419 . \\
119 . \\
419 . \\
419 . \\
119 .\end{array}$ & $\begin{array}{l}10 . \\
100 \\
100 \\
10 . \\
10 .\end{array}$ & $\begin{array}{l}15 . \\
15 \\
15 \\
15 . \\
15 .\end{array}$ & 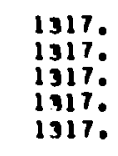 & $\begin{array}{l}1976 . \\
1976 . \\
1976 . \\
1976 . \\
1976 .\end{array}$ & $\begin{array}{l}630 . \\
630 . \\
630 \\
630 \\
630 .\end{array}$ & $\begin{array}{l}945 . \\
945 \\
945 \\
945 \\
945 .\end{array}$ \\
\hline $\begin{array}{l}2001 \\
2002 \\
2003 \\
2004 \\
2005\end{array}$ & $\begin{array}{l}250 . \\
300 . \\
384 . \\
304 . \\
304 .\end{array}$ & $\begin{array}{l}384 . \\
400 . \\
316 . \\
316 . \\
316 .\end{array}$ & $\begin{array}{l}31 . \\
46 . \\
53 . \\
53 . \\
55 .\end{array}$ & $\begin{array}{l}35 . \\
010 \\
430 \\
130 \\
0.0\end{array}$ & $\begin{array}{l}37 ? . \\
405 . \\
558 . \\
558 . \\
554 .\end{array}$ & $\begin{array}{l}558 . \\
698 . \\
838 . \\
838 . \\
838 .\end{array}$ & $\begin{array}{l}13 . \\
17 . \\
20 . \\
20 . \\
20 .\end{array}$ & $\begin{array}{l}20 . \\
25 . \\
30 . \\
30 . \\
30 .\end{array}$ & $\begin{array}{l}17560^{\circ} \\
21950 \\
26340 \\
26340 \\
2634 .\end{array}$ & $\begin{array}{l}2634 . \\
3293 \\
3952, \\
3952, \\
3952 .\end{array}$ & $\begin{array}{r}840 \\
1050^{\circ} \\
1260 \\
1260^{\circ} \\
1260^{\circ}\end{array}$ & $\begin{array}{l}1260^{\circ} \\
15750^{\circ} \\
1890^{\circ} \\
1890^{\circ}\end{array}$ \\
\hline $\begin{array}{l}2000 \\
2007 \\
2000 \\
2009 \\
2010\end{array}$ & $\begin{array}{l}512 . \\
640 . \\
503 . \\
503 . \\
503 .\end{array}$ & $\begin{array}{l}100 . \\
y 60 . \\
1050 \\
1050 \\
105 .\end{array}$ & $\begin{array}{l}74 . \\
92 . \\
72 . \\
72 . \\
72 .\end{array}$ & $\begin{array}{l}110 . \\
130 . \\
100 . \\
100 . \\
100 .\end{array}$ & $\begin{array}{l}744 . \\
431 . \\
7310 \\
731 . \\
731 .\end{array}$ & $\begin{array}{l}1117 . \\
1396 . \\
1097 . \\
1097 . \\
1097 .\end{array}$ & $\begin{array}{l}27 . \\
33 . \\
26 . \\
26 . \\
26 .\end{array}$ & $\begin{array}{l}40 . \\
50 . \\
39 . \\
39 . \\
39 .\end{array}$ & $\begin{array}{l}3512 . \\
4391 . \\
3451 . \\
3451 . \\
3451 .\end{array}$ & $\begin{array}{l}5269 . \\
6586 . \\
5177 . \\
5177 . \\
5177 .\end{array}$ & $\begin{array}{l}1600 . \\
2100 . \\
1651 . \\
1651 . \\
1651 .\end{array}$ & $\begin{array}{l}2520^{\circ} \\
3150^{\circ} \\
2476^{\circ} \\
2476^{\circ} \\
240^{\circ}\end{array}$ \\
\hline $\begin{array}{ll}20 & 11 \\
20112 \\
2019 \\
2014 \\
2015\end{array}$ & $\begin{array}{l}631 . \\
302 . \\
253 . \\
253 . \\
-12 .\end{array}$ & 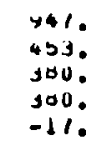 & $\begin{array}{l}91 . \\
36 . \\
36 . \\
-2 .\end{array}$ & $\begin{array}{l}130 . \\
\text { 65. } \\
35 . \\
35 . \\
-2 .\end{array}$ & $\begin{array}{l}918 . \\
434 . \\
369 . \\
369 . \\
-17 .\end{array}$ & $\begin{array}{r}1376 . \\
659 . \\
553 . \\
553 . \\
-25 .\end{array}$ & $\begin{array}{l}33 . \\
16 . \\
13 . \\
13 . \\
-1 .\end{array}$ & $\begin{array}{l}49 . \\
24: \\
20 \\
20 \\
-1 .\end{array}$ & $\begin{array}{r}4329 . \\
2072 . \\
1739 . \\
1739 . \\
-79 .\end{array}$ & $\begin{array}{l}6494 . \\
3109, \\
2608 . \\
2608 . \\
-119 .\end{array}$ & $\begin{array}{l}2071 . \\
991 . \\
832 . \\
832 . \\
-38 .\end{array}$ & $\begin{array}{r}3106 . \\
1487 \\
1247 \\
1247 \\
-57\end{array}$ \\
\hline $\begin{array}{l}2016 \\
2017 \\
2018 \\
2019 \\
2020\end{array}$ & $\begin{array}{l}-12 . \\
-1 \mathrm{H6} . \\
-1 \mathrm{0} . \\
-188 . \\
-365 .\end{array}$ & $\begin{array}{l}-11 . \\
-202 . \\
-202 . \\
-202 . \\
-247 .\end{array}$ & $\begin{array}{l}-2 . \\
-21 . \\
-21 . \\
-21 . \\
-52 .\end{array}$ & $\begin{array}{l}-2 . \\
-41 . \\
-41 . \\
-41 . \\
-79 .\end{array}$ & $\begin{array}{l}-11 . \\
-274 . \\
-274 . \\
-274 . \\
-530 .\end{array}$ & $\begin{array}{l}-25 . \\
-410 . \\
-410 . \\
-410 . \\
-796 .\end{array}$ & $\begin{array}{l}-1 . \\
-10 . \\
-10 \\
-10 \\
-19 .\end{array}$ & $\begin{array}{l}-1 . \\
-15 \\
-15 \\
-15 \\
-29\end{array}$ & $\begin{array}{l}-79 . \\
-1291 . \\
-1291 . \\
-1291 . \\
-2503 .\end{array}$ & $\begin{array}{l}-119 . \\
-1936 . \\
-1936 . \\
-1936 . \\
-3754 .\end{array}$ & $\begin{array}{r}-38 . \\
-617 . \\
-617 . \\
-617 \\
-1197 .\end{array}$ & $\begin{array}{r}-57 . \\
-926 . \\
-926 . \\
-926 . \\
-1795 .\end{array}$ \\
\hline
\end{tabular}




\section{$\underline{\text { TABLE B.11 (contd) }}$}

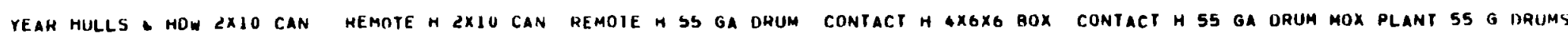

\begin{tabular}{|c|c|c|c|c|c|c|}
\hline $\begin{array}{l}2021 \\
2022 \\
2023 \\
2024 \\
2025\end{array}$ & $\begin{array}{l}-363 . \\
-365 . \\
-365 . \\
-365 . \\
-630 .\end{array}$ & $\begin{array}{l}-541 . \\
-541 . \\
-541: \\
-5410 \\
-545 .\end{array}$ & $\begin{array}{l}-5<. \\
-5<. \\
-5<. \\
-52 . \\
-41 .\end{array}$ & $\begin{array}{l}-14 . \\
-74 . \\
-74 . \\
-14 . \\
-116 .\end{array}$ & $\begin{array}{l}-530 . \\
-530 . \\
-530 . \\
-530 . \\
-916 .\end{array}$ & $\begin{array}{r}-796 . \\
-796 . \\
-796 . \\
-796 . \\
-1374 .\end{array}$ \\
\hline $\begin{array}{l}2026 \\
2027 \\
2028 \\
2029 \\
2030\end{array}$ & $\begin{array}{l}-630 . \\
-610 . \\
-630 . \\
-630 . \\
-806 .\end{array}$ & $\begin{array}{l}-445 . \\
-845 . \\
-445 . \\
-845 . \\
-1210 .\end{array}$ & $\begin{array}{l}-91 . \\
-91 . \\
-91 . \\
-910 \\
-116 .\end{array}$ & $\begin{array}{l}-110 . \\
-1136 . \\
-1130 . \\
-130 . \\
-114 .\end{array}$ & $\begin{array}{l}-916 . \\
-416 . \\
-416 . \\
-916 . \\
-1113 .\end{array}$ & $\begin{array}{l}-1374 . \\
-1374 . \\
-1374 . \\
-1374 . \\
-1759 .\end{array}$ \\
\hline $\begin{array}{l}2031 \\
2032 \\
2033 \\
2034 \\
2035\end{array}$ & $\begin{array}{r}-816 . \\
-516 . \\
0 . \\
0 . \\
0 .\end{array}$ & $\begin{array}{r}-1<10 \\
-804 . \\
0 . \\
0 . \\
0.0\end{array}$ & $\begin{array}{r}-116 . \\
-8.0 \\
0 . \\
0 . \\
0 .\end{array}$ & $\begin{array}{r}-114 . \\
-124 . \\
0 . \\
0 . \\
0 .\end{array}$ & $\begin{array}{r}-1173 . \\
-838 . \\
0 . \\
0 . \\
0 .\end{array}$ & $\begin{array}{r}-1754 . \\
-1256 . \\
0 . \\
0 . \\
0 .\end{array}$ \\
\hline $\begin{array}{l}2036 \\
2037 \\
2038 \\
2039 \\
2040\end{array}$ & $\begin{array}{l}0 . \\
0: \\
0 . \\
0 .\end{array}$ & $\begin{array}{l}0 . \\
0: \\
0: \\
0 . \\
0 .\end{array}$ & $\begin{array}{l}0 . \\
0 . \\
0 . \\
u . \\
0 .\end{array}$ & $\begin{array}{l}0 . \\
0 . \\
0 . \\
0 . \\
0 .\end{array}$ & $\begin{array}{l}0 . \\
0 . \\
0 . \\
0 .\end{array}$ & $\begin{array}{l}0 . \\
0 . \\
0 . \\
0 .\end{array}$ \\
\hline
\end{tabular}

$\begin{array}{ll}-19 . & -29 . \\ -19 . & -29 . \\ -19 . & -29 . \\ -19 . & -29 . \\ -33 . & -49 . \\ -33 . & -49 . \\ -33 . & -49 . \\ -33 . & -49 . \\ -33 . & -49 . \\ -42 . & -63 . \\ -42 . & -63 . \\ -30 . & -45 . \\ 0 . & 0 . \\ 0 . & 0 . \\ 0 . & 0 . \\ 0 . & 0 . \\ 0 . & 0 . \\ 0 . & 0 . \\ 0 . & 0 . \\ 0 . & 0 .\end{array}$

$-2503 .-3754$.

$-2503 .-3754$.

$-2503 .-3754$.
$-2503 .-3754$.

$-2503 .-3756:$
$-4320 .-6481$.

$-4320 .-6481$.

$-4320 .-6481$.

$-4320$

$-4320$.

$-5532 .-8298$.

$-5532 .-8298$.

$\begin{array}{ll}0 . & 0 . \\ 0 . & 0 .\end{array}$

o. 0 .

0.: 0.
$-1197 .-1795$.

$-1197 .-1795$.

$-1197 .-1795$.

$-2066 .-3100$.

$-2066 .-3100$.

-2066 . -3100.

-2066 - 3100 .

$-2646 .-3969$.

$-2646 .-3964$.

:.: 0 :

0.0

0 . 0 .

$\begin{array}{ll}0 . & 0 . \\ 0 . & 0 . \\ 0 . & 0 .\end{array}$ 
TABLE B.12. Early Disposal Scenario Summary (June 21, 1982)

YEAH DISCHARGE AR INV MHS INV REPKUCESS DISHOSAL DISP INV HLW A H HLW MRS OISPOSAL DISP INV

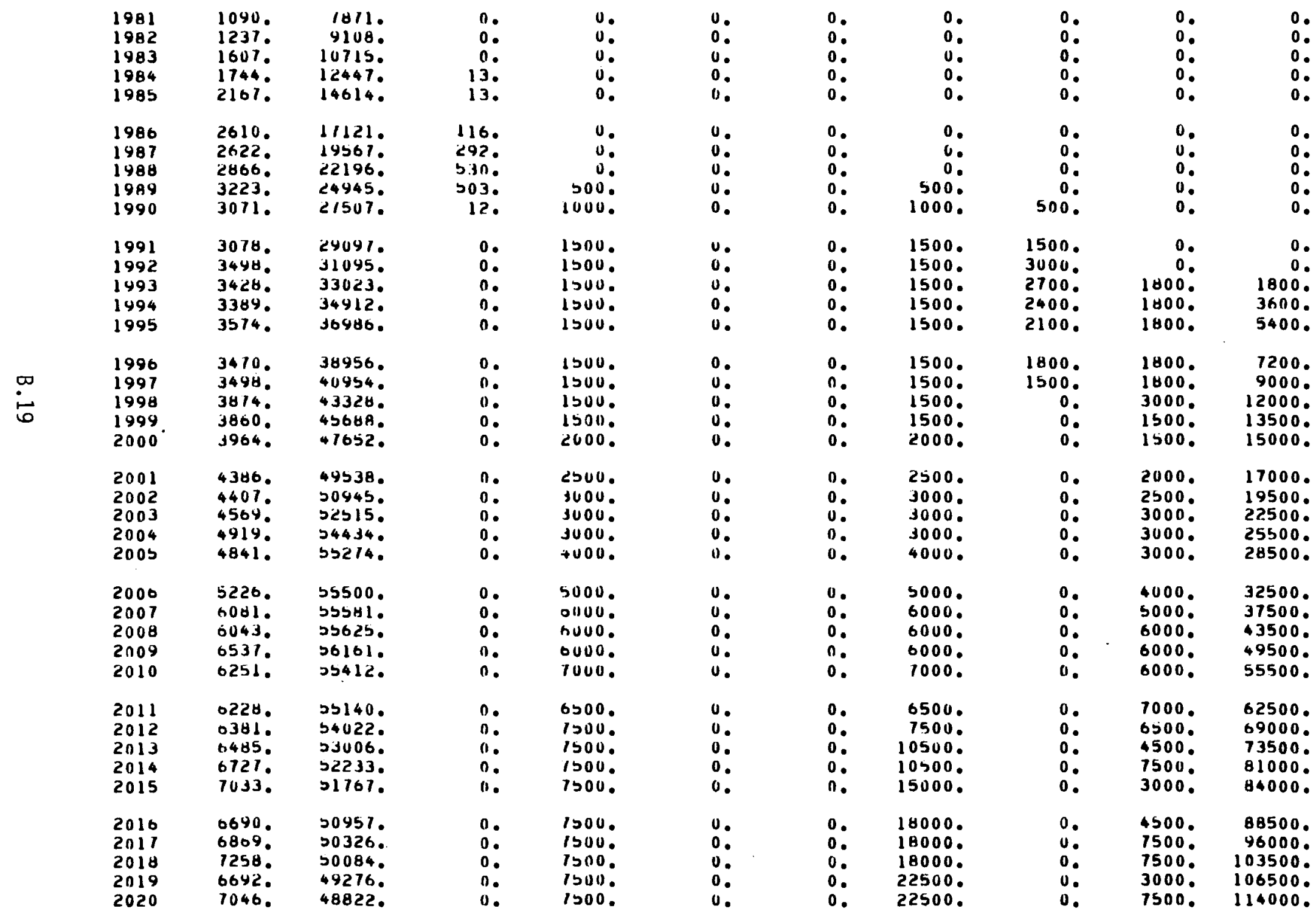


TABLE B.13. Early Disposal Scenario, Fuel and HLW Shipment at MRS (June 21, 1982)

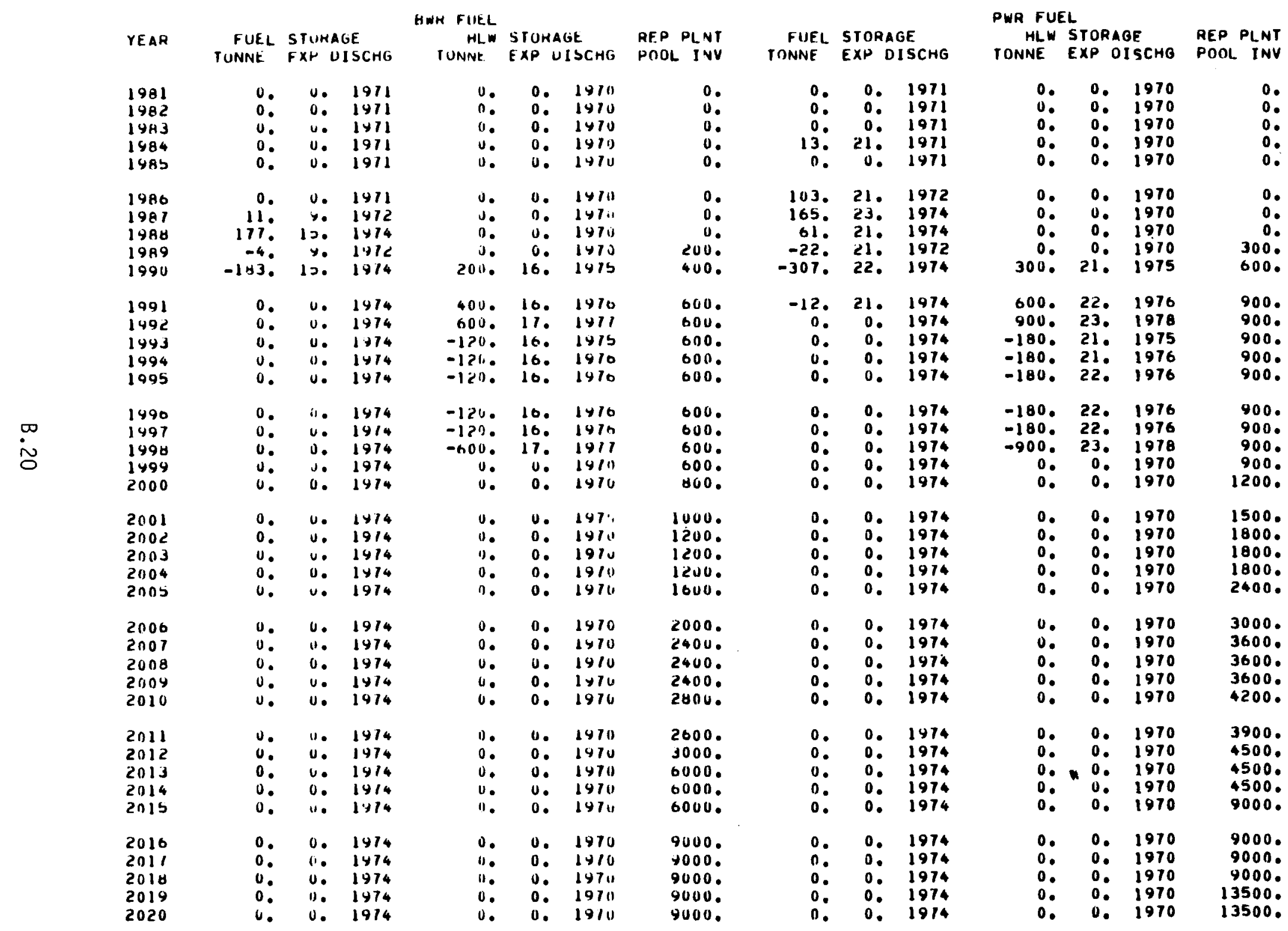


TABLE B.14. Early Disposal Scenario, Number of TRU Packages Handled at MRS (June 21, 1982)

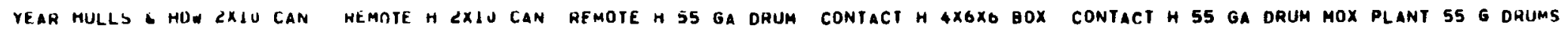

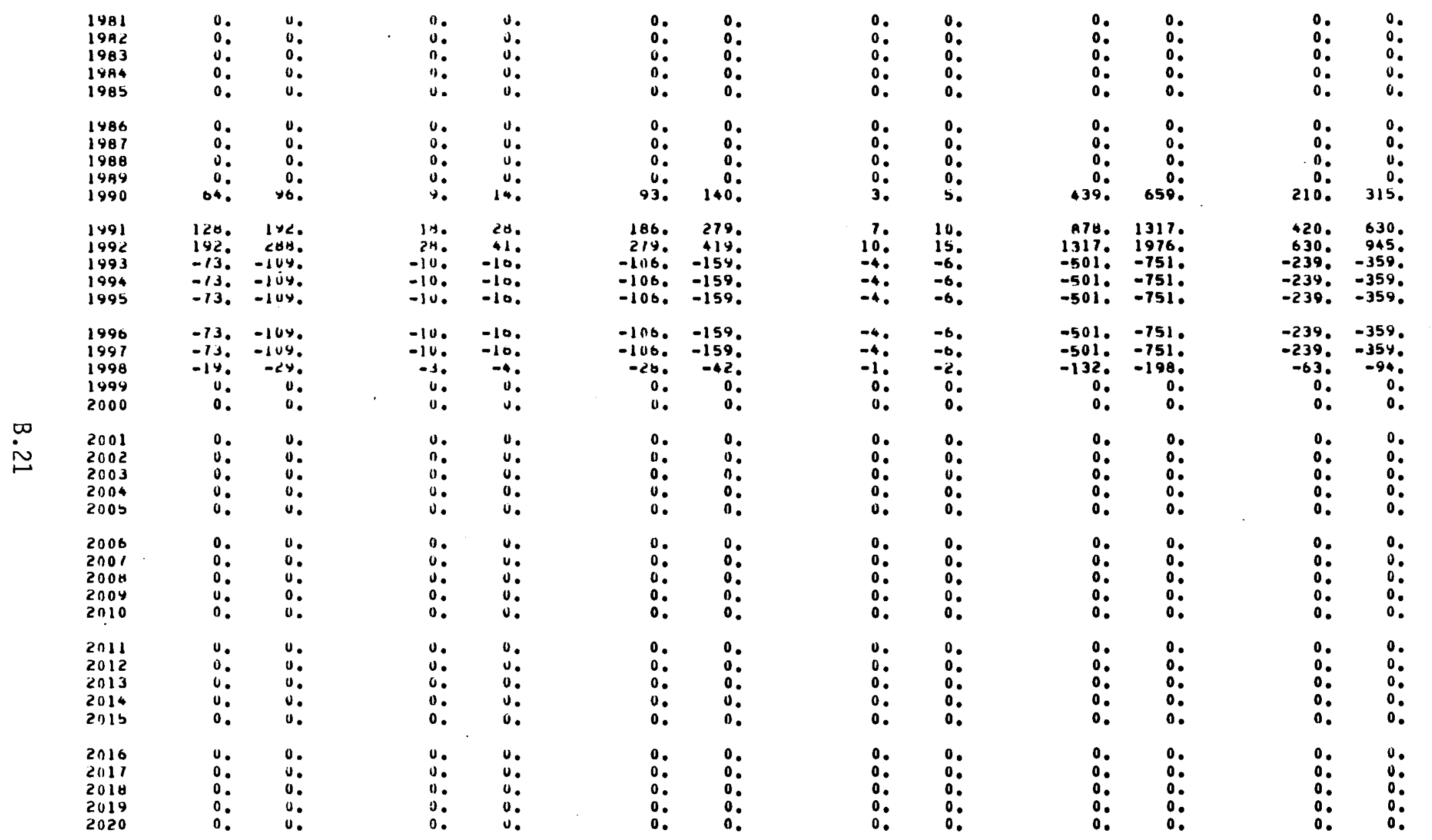


TABLE B.15. Delayed Disposal No Reprocessing Scenario Summary (June 21, 1982)

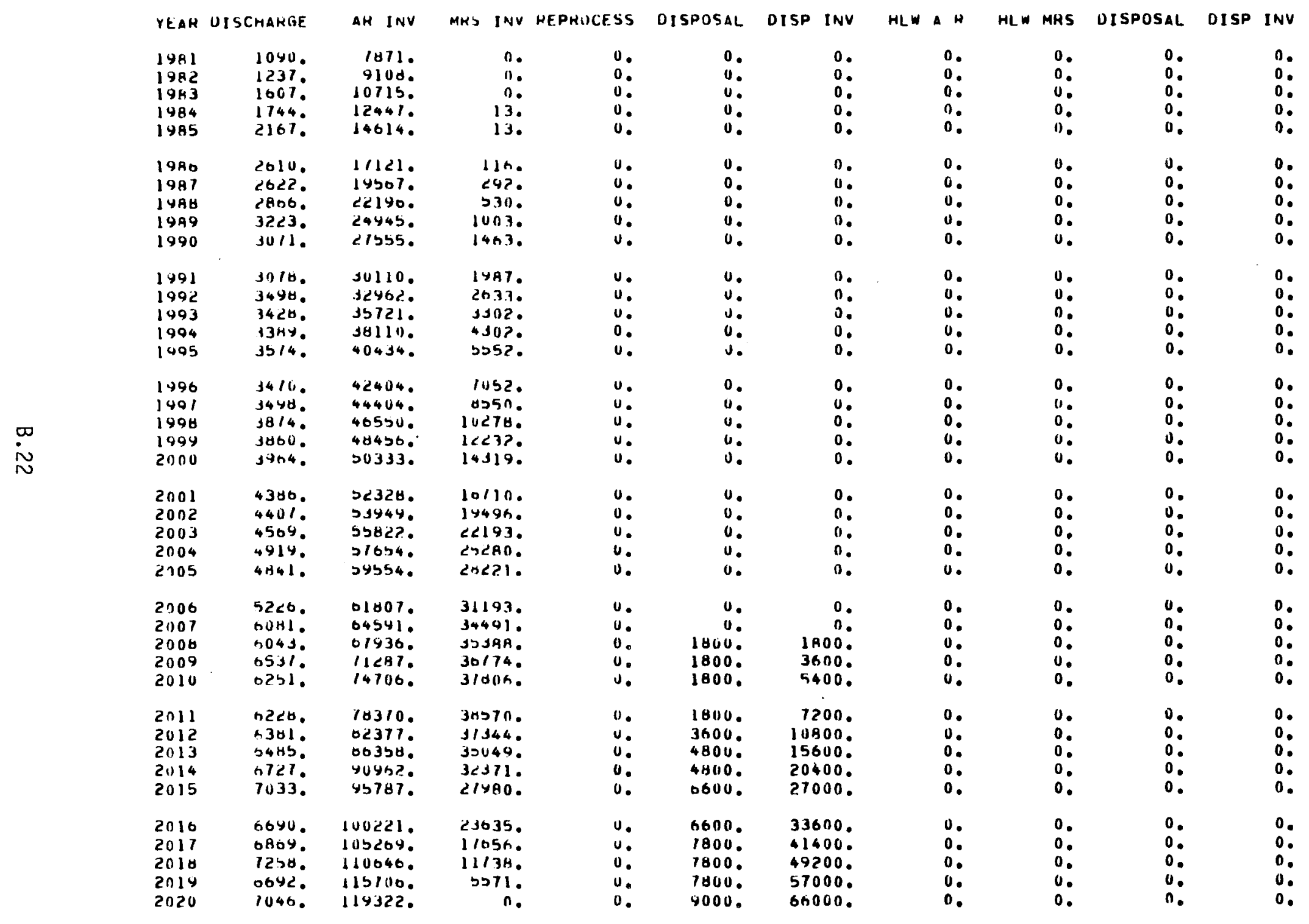


repository delivery rates when a full year's production of HLW is held at the reprocessing plant and a portion of it is not yet 10 years old. The TRU capacity requirements are summarized in Table $B .17$ and the annual handling requirements in Table B.18. The peak rates for the Delayed Disposal case are based on the average removal rates in 2030, 2031, and 2032; however, if a design is modular, it may be desirable to design for a lower rate and add capacity as needed.

TABLE B.17. Required Capacity for TRU Packages at MRS/IS Facility

\begin{tabular}{|c|c|c|}
\hline & Delayed & Delayed \\
\hline ence & Reprocessing & Disposal \\
\hline
\end{tabular}

Hulls and hardware cans

3,400

0

19,400

RHTRU $2 \times 10 \mathrm{ft}$ cans

500

0

2,800

RHTRU 55 gal drums

5,000

0

28,200

CHTRU $4 \times 6 \times 6 \mathrm{ft}$ boxes

175

0

1,010

CHTRU 55 gal drums

24,000

0

133,000

MOX Plant 55 gal drums

12,000

0

64,000

MOX Plant $4 \times 6 \times 6 \mathrm{ft}$

boxes

120

0

640

TABLE B.18. Annual Receiving or Removal Rate for TRU Packages at MRS/IS Facility

Reference \begin{tabular}{cl}
$\begin{array}{c}\text { Delayed } \\
\text { Reprocessing }\end{array}$ & $\begin{array}{l}\text { Delayed } \\
\text { Disposal }\end{array}$ \\
\hline
\end{tabular}

Hulls and hardware cans

760

0

1,850

RTHRU $2 \times 10 \mathrm{ft}$ cans

110

0

270

RHTRU 55-gal drums

1,100

0

2,700

CHTRU $4 \times 6 \times 6 \mathrm{ft}$ boxes

40

95

CHTRU 55 gal arums

5,200

12,500

MOX Plant 55-gal drums

2,500

6,000

MOX Plant $4 \times 6 \times 6 \mathrm{ft}$

boxes

25

0

60 
TABLE B.16. Delayed Disposal No Reprocessing Scenario, Fuel and HLW Shipments at MRS (June 21, 1982)

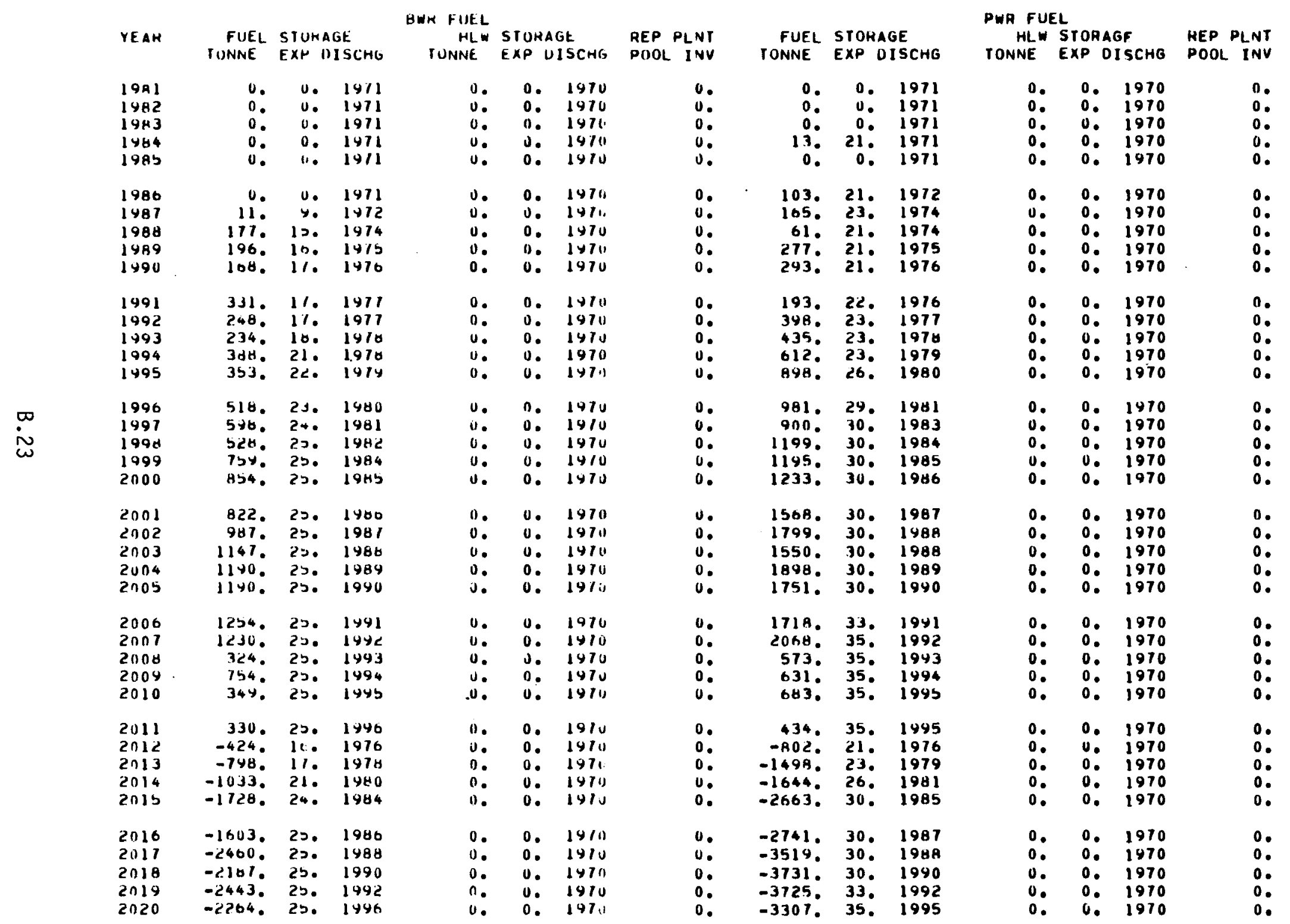


APPENDIX C

TRANSPORTATION INFORMATION 
APPENDIX C

TRANSPORTATION INFORMATION

Presented in this appendix are standardized bases, requirements and unit costs for transporting spent fuel, solidified high-level wastes, remotehandled transuranic wastes, and contact-handled transuranic wastes as required in the various fuel cycle scenarios. Also presented are the numbers of packages and shipments of each type and the estimated costs for each.

\section{C.1 TRANSPORTATION UNIT COSTS}

This section contains the unit transportation costs used in the preconceptual design studies for the Monitored Retrievable Storage/Interim Storage (MRS/IS) program in FY-82. The bases and assumptions pertaining to transportation for use in the preconceptual design study are also documented in this section. Unit transportation costs are calculated for four fuel cycle materials: spent fuel, high-level wastes (HLW), remote-handled transuranic (RHTRU) wastes, and contact-handled (CH) TRU wastes. RHTRU wastes are further subdivided into three categories: wastes that are packaged in special cylindrical canisters (including compacted cladding hulls), wastes that are packaged in "standard" 210-1iter (55 gal) drums with surface dose rates less than $5 \mathrm{R} / \mathrm{hr}$, and drummed wastes with surface dose rates greater than $5 \mathrm{R} / \mathrm{hr}$. Transportation costs are calculated for shipments by truck and by rail.

Three waste management scenarios are currently under study by the MRS/IS program. They include interim storage facilities located either at a fuel reprocessing plant, a geologic waste disposal repository, or a stand-alone facility. The transportation links and the assumed mileages between each facility are defined. Transportation in this study stops at the fences of the terminal facilities; i.e., onsite transportation is considered as facility handling operations. The reference shipping systems for transporting the spent 
fuel and HL and TRU wastes between the facilities are selected. Several criteria were used for selecting these systems, in particular the use of existing or near-existing technology, licensability, and compatibility with reference canister sizes. The reference shipping systems selected for use in this study are shown in Table C.1. The reference canister dimensions are also defined.

Transportation costs for the FY-82 MRS/IS program studies are based on the assumption that private industry will provide the transportation services as a commercial venture, although the services could be owned and provided by the government. Therefore, total transportation costs are the sum of the shipping charges, special equipment and security costs (where applicable) and shipping container rental fees. The unit transportation costs for truck and rail shipments of the six different cargoes are summarized in Table C.2.

Special equipment charges and security costs are currently required for shipments of spent fuel and may be required for shipments of high-level wastes in the future. The costs for HLW shipments shown in Table C.2 include these additional costs.

Introduction

The objectives of the MRS/IS program are to provide Federal contingency capability for storing spent nuclear fuel until a reprocessing facility can eliminate the need for such storage and to provide Federal capability for storing solidified high-level wastes (HLW) and transuranic (TRU) wastes until a waste disposal repository becomes available. Currently, two dry storage concepts are being evaluated to determine their effectiveness for reducing near-term spent fuel and waste storage space shortages. The two concepts consist of storage in large metal casks and drywells. Both concepts offer passive, low cost, easily maintained systems that can be expanded in increments which can be constructed according to demand. The degree of flexibility of these storage concepts is being assessed by comparing the results of using casks and drywells to provide interim storage. The two storage concepts are being evaluated as to their technical status, life cycle costs, safety and licensing issues, environmental issues, transportation considerations, and research and development requirements. 
TABLE C.1. Reference Shipping Systems Selected for Study

\begin{tabular}{|c|c|c|c|c|}
\hline Material & $\begin{array}{c}\text { Shipping } \\
\text { Mode }\end{array}$ & $\begin{array}{r}\text { Shipping } \\
\text { Container }\end{array}$ & $\begin{array}{c}\text { Canisters } \\
\text { per } \\
\text { Shipment }\end{array}$ & $\begin{array}{l}\text { Leasing } \\
\text { Fee, } \\
\text { \$1Day } \\
\end{array}$ \\
\hline \multirow[t]{2}{*}{ Spent fuel } & Truck & $N A C-1$ & $\begin{array}{l}1 \text { PWR or } \\
2 \text { BWR }\end{array}$ & $2000(a)$ \\
\hline & Rail & IF -300 & $\begin{array}{l}7 \mathrm{PWR} \text { or } \\
18 \mathrm{BWR}\end{array}$ & 5750 \\
\hline
\end{tabular}

\begin{tabular}{|c|c|c|c|c|}
\hline High-level & Truck & NAC-1 & 1 canister & 2000 \\
\hline & Rail & IF -300 & 5 canisters & 5750 \\
\hline RHTRU special & Truck & HLW-T & 1 canister & 1750 \\
\hline & Rail & $H L W-R$ & 5 canisters & 4375 \\
\hline RHTRU drums & Truck & CNS $14-170$ & 14 drums & 175 \\
\hline & $\operatorname{Rai}(\mathrm{b})$ & CNS $14-170$ & 42 drums & 525 \\
\hline RHTRU drums & Truck & CNS $7-100$ & 7 drums & 775 \\
\hline & $\operatorname{Ra} i{ }^{(b)}$ & CNS $7-100$ & 21 drums & 525 \\
\hline CHTRU wastes & Truck & TRUPACT & $\begin{array}{l}36 \text { arums or } \\
3 \text { boxes }\end{array}$ & 700 \\
\hline & $\operatorname{Raj}(c)$ & TRUPACT & $\begin{array}{l}72 \text { drums or } \\
6 \text { boxes }\end{array}$ & 1400 \\
\hline
\end{tabular}

(a) Leasing fee for the NAC-1 is calculated from a schedule.

(b) It is assumed that three of these shipping containers can be transported per railcar.

(c) Assumes two truck TRUPACT versions are transported per railcar. 
TABLE C.2. Round-Trip Transportation Costs for Truck and Rail Shipments of Spent Fuel and High-Level and Transuranic Wastes $(a)$

\begin{tabular}{|c|c|c|c|c|}
\hline & Shipping & $\begin{array}{r}\text { Round-Tr } \\
\text { One-l}\end{array}$ & $\begin{array}{l}\text { it Trans } \\
\text { les, } \$ / S\end{array}$ & $\begin{array}{l}\text { tion Costs } \\
n t(b, c)\end{array}$ \\
\hline Material & Mode & 500 & 2000 & 2500 \\
\hline Spent fuel(d) & Truck & 12,170 & 29,010 & 34,710 \\
\hline & Rail & 91,140 & 216,920 & 26,240 \\
\hline High-level(d) & Truck & 12,200 & & 31,510 \\
\hline & Rail & 91,210 & & 262,410 \\
\hline RHTRU wastes; & Truck & 9,280 & & 23,030 \\
\hline & Rail & 69,670 & & 193,770 \\
\hline RHTRU wastes; & Truck & 3,450 & & 10,825 \\
\hline & Rail & 21,090 & & 57,530 \\
\hline RHTRU wastes; & Truck & 3,380 & & 10,645 \\
\hline & Rail & 20,770 & & 55,680 \\
\hline CHTRU wastes & Truck & 5,310 & & 14,380 \\
\hline & Rail & 25,600 & & 70,600 \\
\hline
\end{tabular}

(a) Transportation costs include shipping charges, special equipment and security costs (where applicable) and shipping system rental fees.

(b) Rounded to the nearest ten dollars.

(c) These costs do not include demurrage fees for truck shipments. These are, on the average, $\$ 29.30$ for each hour of turnaround time at the terminal facilities. Rail demurrage fees are calculated using shipping system rental fees.

(d) Costs include charges for special equipment and escort services.

The purpose of this document is to provide standardized assumptions and unit costs for transportation to be used to set a baseline for common comparison of lifetime transportation costs. Unit costs are developed for transporting four types of radioactive materials: spent fuel, solidified high-level wastes, remote-handled transuranic (RH-TRU) wastes, and contact-handled TRU (CH-TRU) wastes. RH-TRU wastes are further divided into 
special canisters and two types of drummed wastes, so a total of six fuel cycle materials are considered in this study. In addition to transmitting standardized assumptions and transportation unit costs, this report defines the reference transportation systems for the MRS/IS program. Also included is an estimate of the costs of requiring security provisions for high-level waste shipments similar to those required for spent fuel in transit.

Bases and Assumptions

The bases for calculating unit transportation costs and key assumptions that were made to facilitate these calculations are discussed in this section. The section includes definition of the transport links connecting the fuel cycle facilities considered in this study. Transportation in this study refers only to offsite shipments, in the general public domain (i.e., between fences of the terminal facilities). Onsite transportation is considered as handling at the facility and is not included here. However, onsite handling of the cross-country vehicles and packagings can affect facility turnaround times and thus the cost of cross-country transport. Shipping parameters and transportation costs for six fuel cycle materials are considered: spent fuel, solidified high-level wastes, RHTRU cladding hulls, other RHTRU wastes, and CHTRU wastes.

At this time in the U.S., no commercial reprocessing of spent nuclear fuel to reclaim valuable uranium and plutonium is occurring. As a result, the spent fuel is being stored in reactor fuel storage basins. The maximum capacity of many of these basins is being reached. The strategy used in the MRS/IS studies assumes that: 1) the government will accept and store excess spent fuel in a federally owned facility until a fuel reprocessing plant (FRP) becomes available; 2) in the reference case, a $1500 \mathrm{MgHM} /$ year FRP will open in 1989 and the MRS/IS will accept and store HL and TRU waste from that operation until a repository is available; 3 ) the $\mathrm{HL}$ and TRU waste generated by the FRP will ultimately be shipped to a repository for final isolation; and 4) a generic mixed-oxide fuel fabrication plant will begin operation in 1989 . A gap exists between the 1998 planned opening date for the repository and the FRP opening date of 1989. The HLW and TRU wastes generated during this period will be shipped to an MRS/interim storage facility until they can be shipped to the repository for final isolation. 
Transport links connecting the storage facilities and power reactors are shown in Figure C.1. Co-locating the MRS/IS facility at the repository eliminates transportation of $H L W$ and TRU wastes from interim storage to the repository.

One purpose of this report is to define the reference transportation systems for use in the facility evaluations. There is no intent to endorse or reject any particular shipping system. Reference systems, however, were selected to provide consistency within this study using state-of-the-art hardware. Primarily, the systems selected were existing and licensed where available. If no such systems exist, those that are well along in the design stage were selected. Another criterion that must be met by the shipping system is that of licensability. Application of this criterion requires judgment as to whether or not a conceptual shipping system is expected to eventually meet the packaging regulations in 10 CFR 71 .

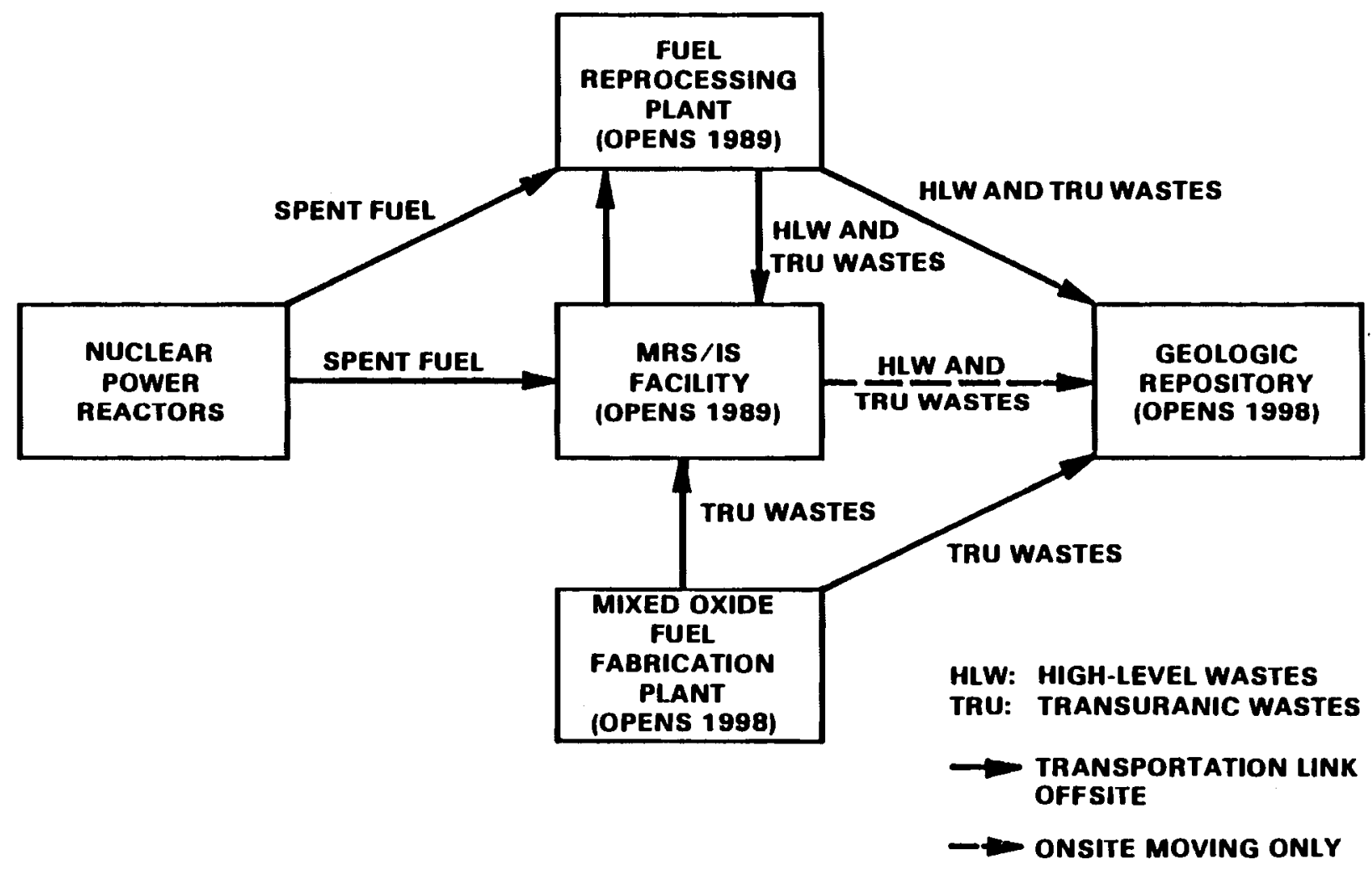

FIGURE C.1. Transportation Links for Co-locating the Interim Waste Storage Facility with the Repository 
A third criterion concerning the selection of the shipping systems is the sizes of the reference canisters assumed as the primary container for the high-level and transuranic wastes. The reference canister sizes for this study are shown in Table C.3.

The reference shipping systems in this study were selected to accommodate these sizes of canisters. Some inconsistencies may exist between these canisters and the canisters that the FRP is planning to use. For example, the cladding hulls canister the FRP is planning to use is $1.1 \mathrm{~m}(3.7 \mathrm{ft})$ in diameter and $2.3 \mathrm{~m}(7.5 \mathrm{ft})$ long. This canister, due to its large diameter, was not transportable in any of the spent fuel or high-level waste truck shipping casks. Therefore, to be more compatible with storage and shipping casks, the equivalent volume of waste is assumed to be transported in a larger number of $0.62 \mathrm{~m}(2 \mathrm{ft})$ diameter canisters for this study.

TABLE C.3. Reference Canister Sizes and Weights for Definition of Shipping Systems and Shipment Parameters

\begin{tabular}{|c|c|c|c|}
\hline Fuel Cycle Material & Dimensions, m & $\begin{array}{c}\text { Net }^{(a)} \\
\text { Capacity, } \mathrm{m}^{3}\left(\mathrm{ft} \mathrm{t}^{3}\right) \\
\end{array}$ & $\begin{array}{r}\text { Average } \\
\text { Weight } \\
\text { Loaded, kg (1b) } \\
\end{array}$ \\
\hline \multicolumn{4}{|l|}{ Spent fuel } \\
\hline PWR assembly & NA & $N A$ & $658(1448)$ \\
\hline BWR assembly & NA & NA & $284(625)$ \\
\hline $\begin{array}{l}\text { Solidified high-level } \\
\text { waste canister }\end{array}$ & $0.310 \times 3.1$ & $0.17(6.0)$ & $1050(2310)$ \\
\hline \multicolumn{4}{|l|}{ RHTRU wastes } \\
\hline $\begin{array}{l}\text { Hulls canister } \\
210 \text { L (55 gal) drum }\end{array}$ & $\begin{array}{l}0.620 \times 3.1 \\
0.620 \times 0.92\end{array}$ & $\begin{array}{l}0.75(2.6) \\
0.17(6.0)\end{array}$ & $3500(7700)$ \\
\hline $\begin{array}{l}\text { CH-TRU Wastes } \\
210 \text { L (55-gal) drum } \\
\text { Metal box }\end{array}$ & $\begin{array}{l}0.620 \times 0.92 \\
1.2 \times 1.9 \times 1.9\end{array}$ & $\begin{array}{l}0.19(6.7) \\
3.5(123.6)\end{array}$ & $\begin{aligned} 300 & (660) \\
4000 & (8800)\end{aligned}$ \\
\hline
\end{tabular}


A key assumption that simplifies the selection of the shipping systems is that the canister provides the second level of containment for plutonium bearing wastes, as required in federal regulations (10 CFR 71). The casks or shipping packagings provide only one level of containment. A final assumption concerning selection of the truck shipping systems is that they will all be legal-weight systems, i.e., gross-vehicle weight (tractor plus trailer plus loaded cask weights) do not exceed $36,400 \mathrm{~kg}(80,000 \mathrm{lb})$. It is recognized that over-weight truck shipments may be more economical than legal-weight shipments, but for this stuay, there was insufficient time to adequately calculate the charges for over-weight shipments. This would include defining specific routes and finding what each state on each route charges as an over-weight penalty. In addition, the use of overweight trucks routinely for numerous shipments would require considerable administrative efforts to obtain repeatedly the special permits from the states involved.

Shipping distances must be defined to calculate transportation costs. For the purposes of this study, two distances that represent somewhat bounding cases are defined. The first distance is $4000 \mathrm{~km}$ (2500 miles), which represents a cross-country shipment. The second distance is $800 \mathrm{~km}$ (500 miles), which was chosen because it approximates a typical distance between eastern power reactors and BNFP. The cost for each transport link in the evaluation studies of three sites for MRS/IS facilities is calculated using both of these distances.

The assumed distances must be assigned to the various transportation links in Figure C.1. Since most of the commercial reactors are in the east and the FRP will be in the east, the transportation link connecting these facilities is assumed to be $800 \mathrm{~km}$ (500 miles). The disposal repository is assumed to be in the west, which results in the $4000 \mathrm{~km}$ (2500 mile) transport distance between the FRP and repository and the MOX-FFP and repository. The MRS/IS facility is also assumed to be $4000 \mathrm{~km}$ from the reactors.

It is assumed in this study that 50 percent of the spent fuel and waste transported to the MRS/IS facility is to be shipped by truck and 50 percent by rail. This shipping mode split was chosen because it is not clear what mode 
of transport will be most extensively used in the future. Each has its own advantages and disadvantages. The reference truck/rail shipping split reflects no bias toward either mode.

Mid-year 1982 dollars were used when calculating transportation unit costs. Transportation costs are calculated as though private industry was shipping on a commercial basis even though that may eventually not be the case. Costs include operating costs plus amortization costs of hardware plus profits, at commercial rates. Therefore, transportation costs include the shipping charges assessed by carriers and the rental fees assessed by transportation hardware suppliers. A third factor in transportation costs is a fee for demurrage or detention of a carrier's equipment (railcars or truck-trailer rigs) and for drivers while unloading at terminal facilities. These three transportation factors are assumed to be supplied by the private sector as a commercial venture. Thus the total transportation costs are calculated as follows:

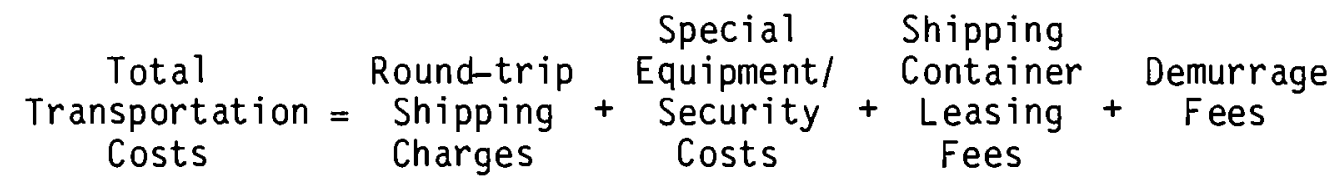

\section{Transportation System Descriptions}

This section describes transportation systems selected for this study for the five fuel cycle materials under consideration in this study: spent fuel, solidified HLW, TRU-contaminated fuel cladding hulls, other RHTRU wastes, and CHTRU wastes. Two shipping systems, one truck version and one rail version, are described for each material. It is bel ieved that the future nuclear waste management system will integrate their waste container designs with transportation system designs to provide compatible and optimum shipping configurations. Therefore, if a minor modification to the shipping containers results in significantly increased capacities, it is assumed this will be done. These modifications are noted where they occur.

Table C.4 lists the important shipping parameters and characteristics of the truck and rail shipping systems used in this study. Supplementary descriptive information is contained in the following sections. 
TABLE C.4. Characteristics of Transportation Systems for the MRS/IS Program

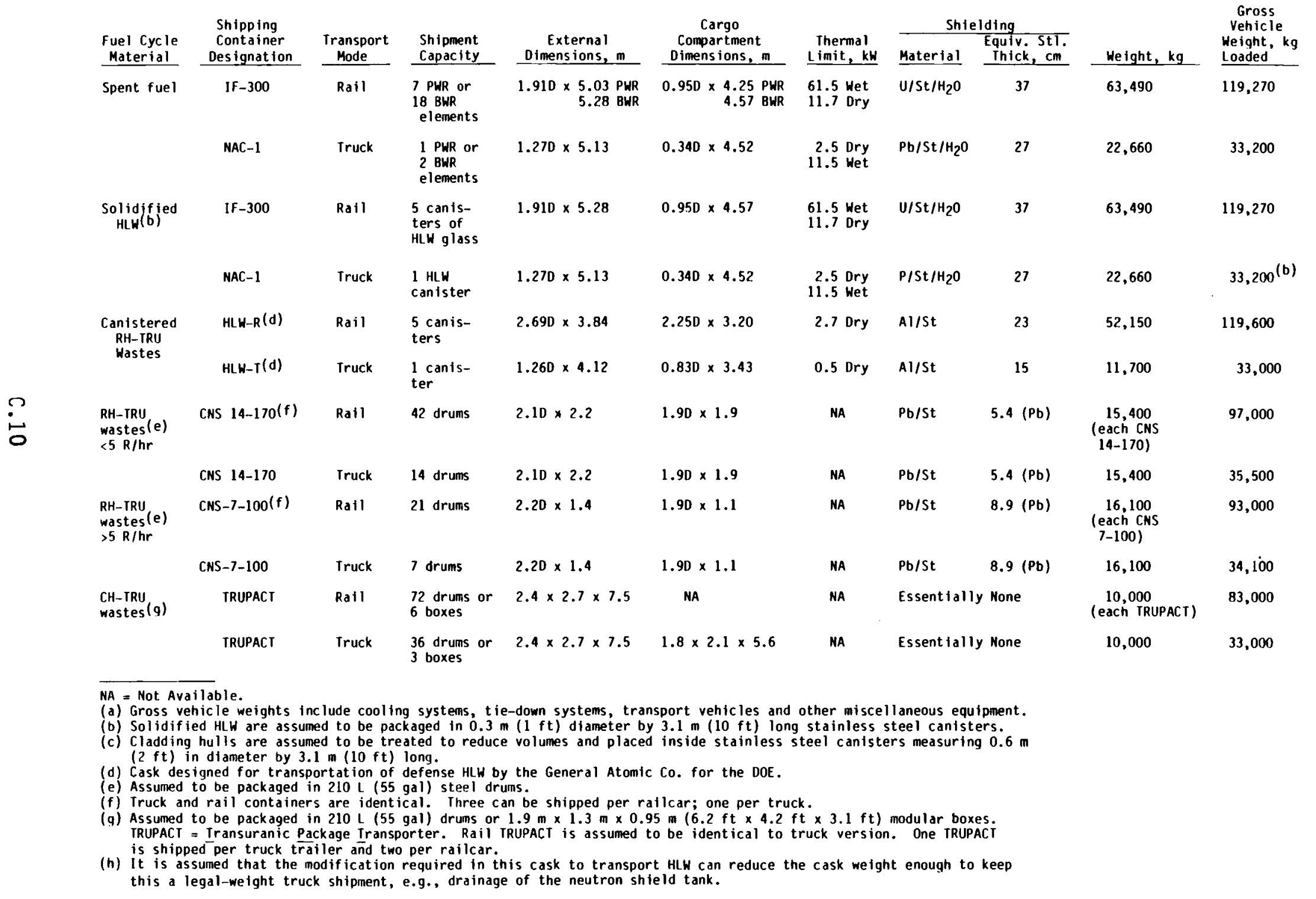


Spent fueT Shipping System

The representative truck and rail shipping systems used in this study are the NAC-1 owned by the Nuclear Assurance Corporation and the IF-300 owned by the General Electric Company, respectively. The NAC-1 and IF-300 shipping casks are depicted in Figures $C .2$ and C.3, respectively. The NAC-1 legal weight truck system uses a water-filled cask designed to transport one PWR or two BWR spent fuel assemblies. Decay heat from the spent fuel is removed by conduction and natural convection through the cask body and is released to the atmosphere by natural convection and radiation. The NAC-1 is currently shipped at a reduced heat loading.

The IF-300 cask of General Electric Company is a water-filled cask (a)though it is currently shippped dry), designed for rail transport of 7 PWR or 18 BWR spent fuel assemblies. Decay heat is removed from the fuel by natural circulation of the coolant (water, when used), by natural convection and conduction to the external surface, and by forced convection from the external surface to the environment. The forced convection (air impingement) system consists of two diesel-driven blowers and appropriate air ducts. In addition, the cask outer surface is corrugated to facilitate external cooling. The maximum heat-rejection capacity is $76 \mathrm{~kW}$ with blowers operating and $62 \mathrm{~kW}$ without blowers.

\section{High-Level Waste Shipping Systems}

Transportation systems for solidified high-level wastes have been conceptually designed but not built. These systems are expected to resemble the current generation of spent fuel shipping casks. Therefore, the shipping systems previously described for transport of spent fuel are also assumed to be used to transport high-level wastes in this study. Some minor modifications to the spent fuel casks are required, e.g., designing a new internal basket for the IF-300 with a capacity for five HLW canisters, but it is assumed that these casks would be licensable for HLW shipments by using appropriate baskets and spacer inserts. The only change to the "cask characteristics" is the cargo weights. It is recognized that the NAC-1 and IF-300 are not optimized for transporting high-level wastes and that future transportation systems may have higher cargo capacities for a given gross weight. 


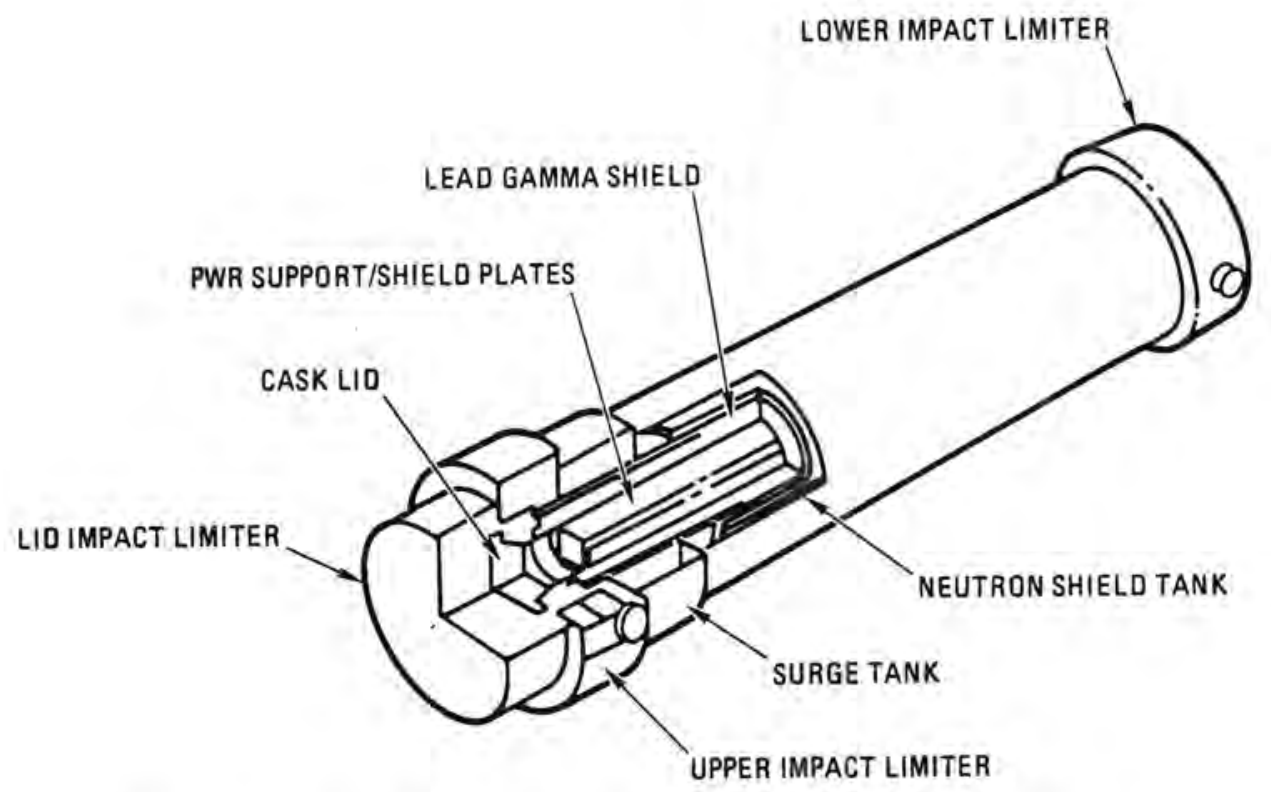

FIGURE C.2. NAC-1 Truck Spent Fuel Shipping Cask

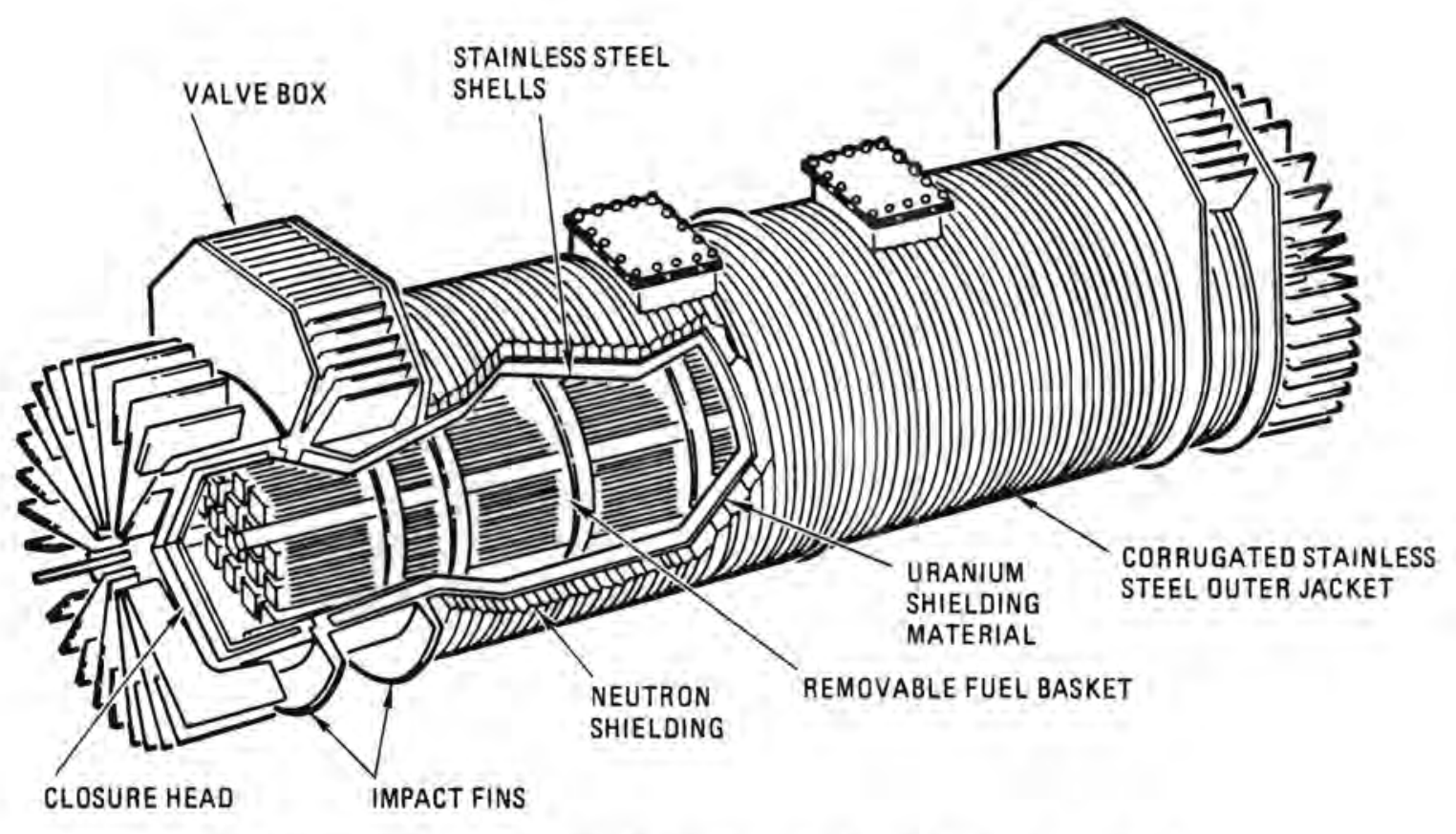

FIGURE C.3. IF-300 Rail Spent Fuel Shipping Cask 


\section{RHTRU Waste Shipping Systems}

Different shipping systems are required to transport "standard" 55 gal drums and other special canisters for RHTRU wastes. Special canisters $(0.62 \mathrm{~m}$ in diameter and $3.1 \mathrm{~m}$ long) are assumed to be transported in casks currently designated HLW-T and HLW-R for truck and rail versions, respectively. These casks are being designed by the General Atomic Company to transport defense high-level wastes for the DOE. They are assumed in this study to be licensable for transporting commercial RH-TRU wastes. The HLW-T cask is a thick-walled steel cylinder similar to the current generation of spent fuel truck casks. This cask can accommodate one special canister. The HLW-R cask is a cylindrical, solid steel cask capable of transporting five canisters. Conceptual drawings of these casks are shown in Figures C.4 and C.5, respectively.

RHTRU wastes are also packaged in standard 55-gal drums, having various dose rates from $200 \mathrm{mR} / \mathrm{hr}$ to several hundred $\mathrm{R} / \mathrm{hr}$. To make the economics of transport more realistic for the additional shielding needs, two shipping containers with different features are assumed to be used. For RHTRU waste drums with surface dose rates less than $5 \mathrm{R} / \mathrm{hr}$, the shipping container selected is the Chem-Nuclear Systems, Inc. cask designated CNS 14-170 (Figure C.6 shows a drawing of the CNS 14-170). This is a top-loading, lead and steel shipping cask for dewatered or solidified waste material. It is assumed to be licensable for transportation of TRU wastes.

RHTRU waste drums with surface dose rates exceeding $5 \mathrm{R} / \mathrm{hr}$ are assumed to be shipped in the CNS 7-100 cask. The maximum dose rate for drums in the CNS $7-100$ is $100 \mathrm{R} / \mathrm{hr}$. Any exceeding this value are assumed to be shipped in the HLW-T and HLW-R casks. The CNS 7-100 is a lead and steel shipping cask (Figure C.7) currently used to transport dewatered or solidified waste materiat. It is also assumed to be licensable for transporting transuranic wastes. 


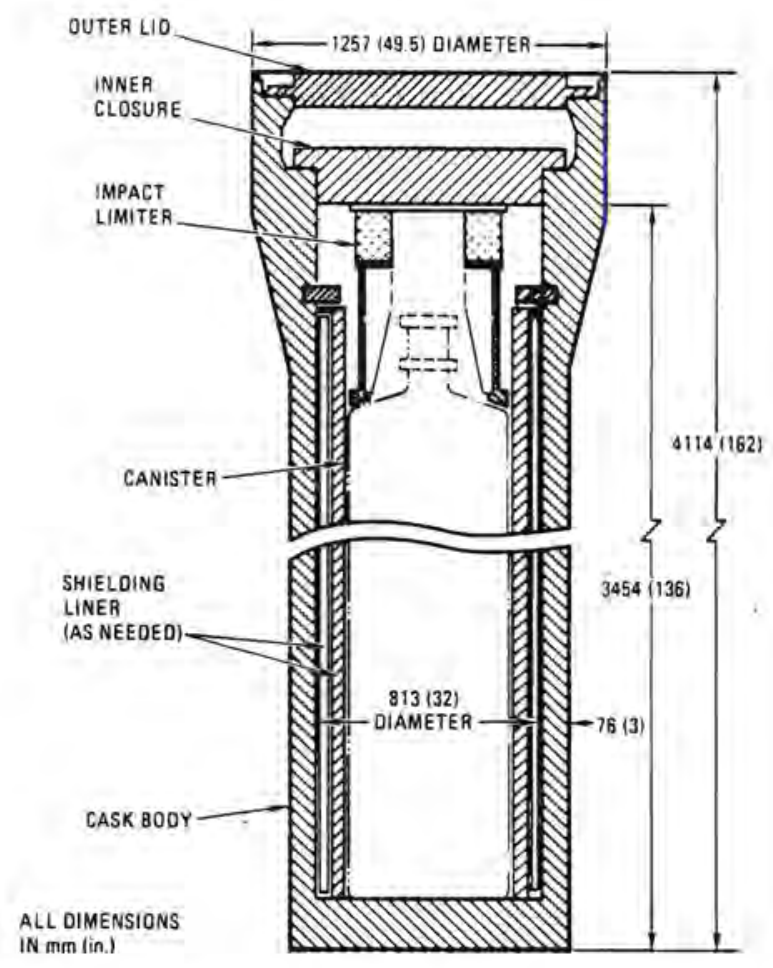

FIGURE C.4. Reference Truck Cask for Transportation of Hulls Canisters (HLW-T cask)

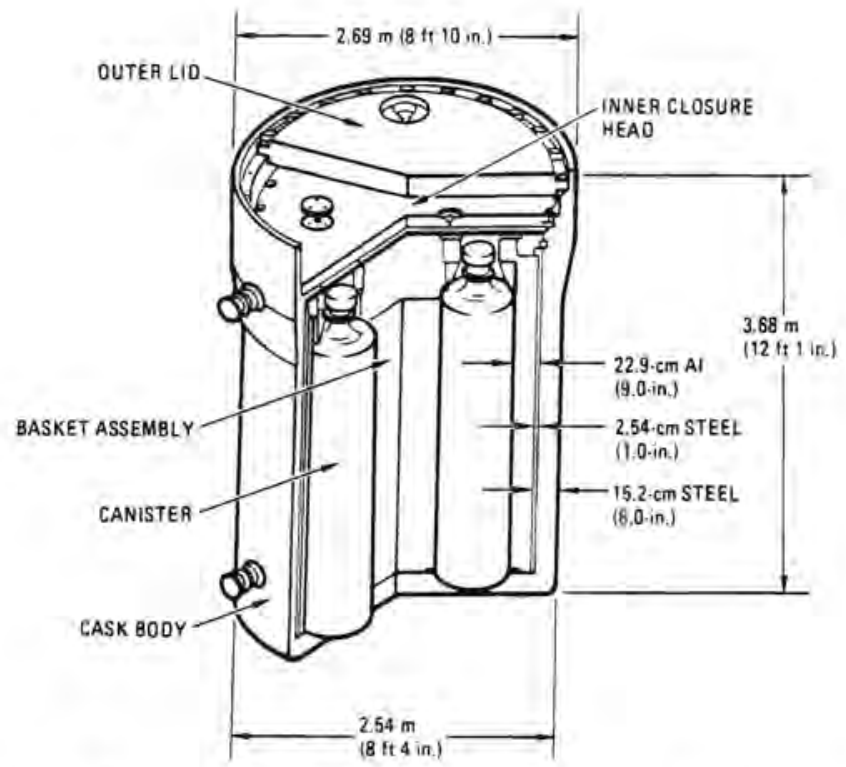

FIGURE C.5. Reference Rail Cask for Transportation of Hulls Canister (HLW-R cask) 


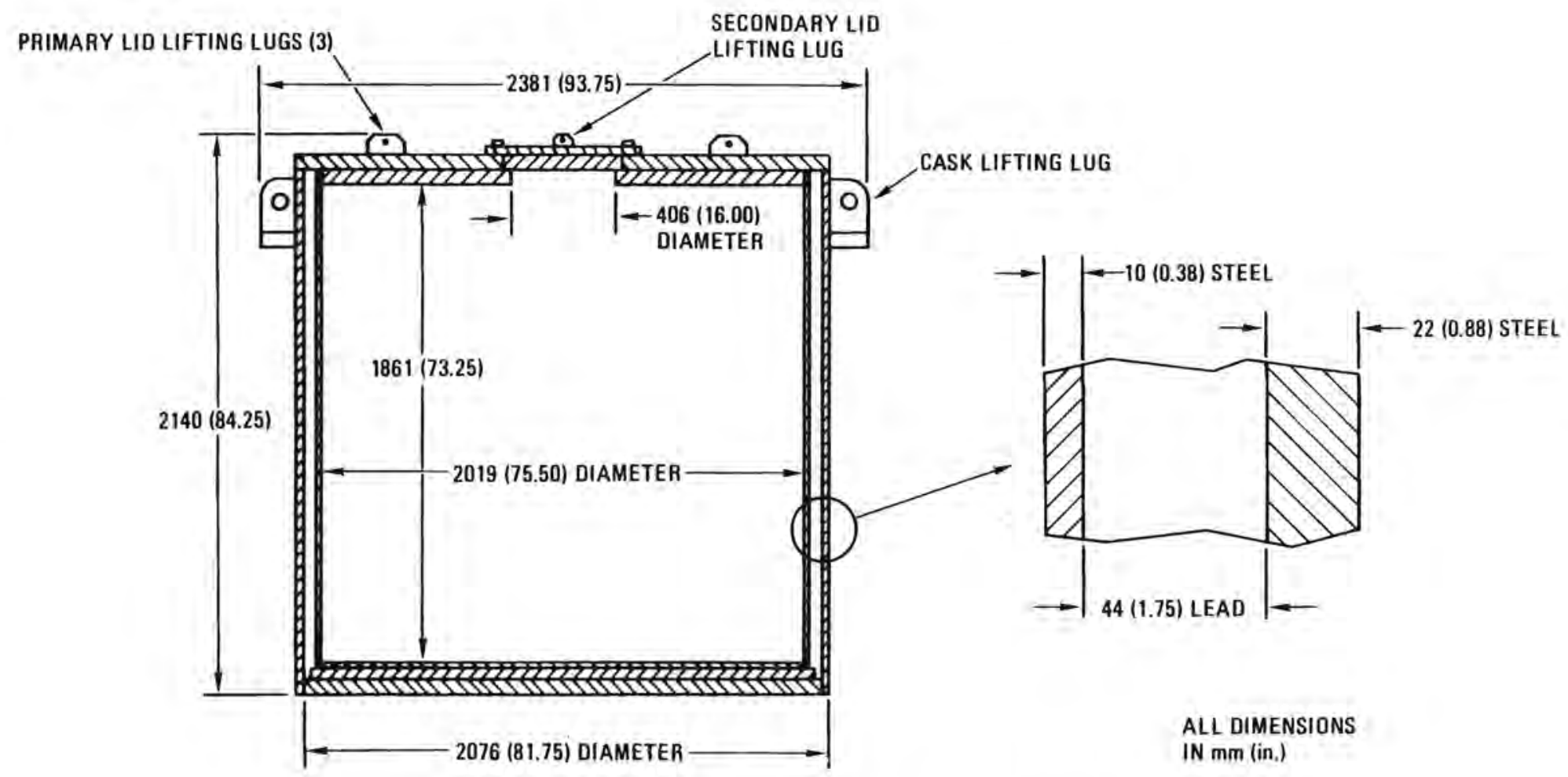

FIGURE C.6. CNS 14-170 Shipping Container 


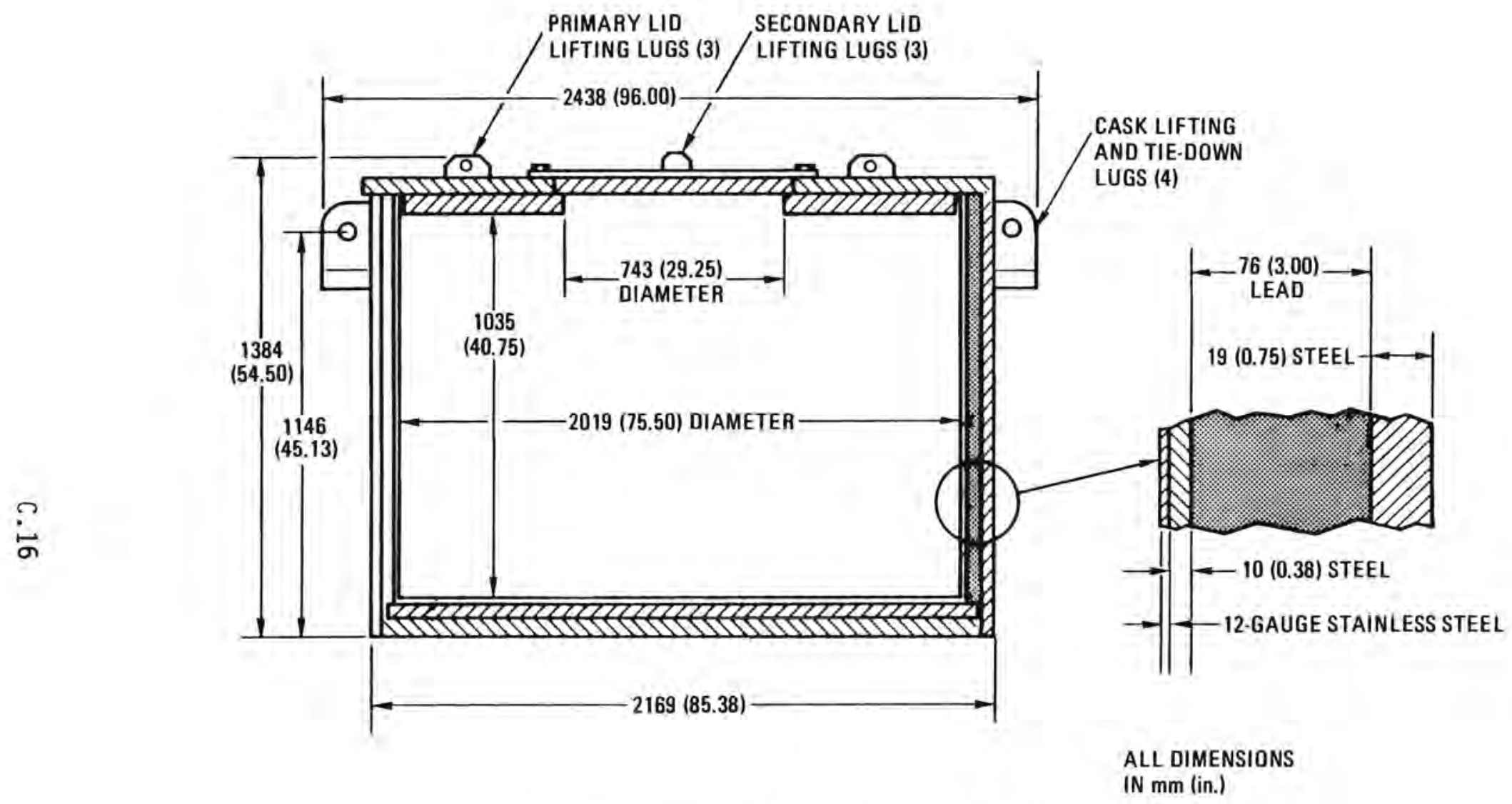

FIGURE C.7. CNS 7-100 Shipping Cask 


\section{CHTRU Waste Shipping Systems}

The TRansUranic PACkage Iransporter is the reference CHTRU waste shipping system selected for use in this study. The TRUPACT is being developed by the Sandia National Laboratories/Transportation Technology Center and the General Atomic Company for the DOE specifically to provide the containment required to haul 1arge quantities of defense CHTRU wastes. Both truck and rail versions of the TRUPACT are being developed. However, because there are more uncertainties about the availability of a rail version, the TRUPACT system used for rail transport in this study consists of two truck versions shipped on a railroad flatcar. The truck system consists of a single TRUPACT shipped on a flatbed truck trailer.

As presently conceived, the TRUPACT (Figure C.8) will have inner and outer steel frameworks made of rectangular tubing. Steel sheets covering the inner and outer surfaces of the inner and outer frameworks are separated by about $0.3 \mathrm{~m}$ (12 in.) of high-temperature insulation and rigid polyurethane foam.

The inner liner is built of stainless steel sheets; the outer shell may be carbon steel or stainless steel. A steel puncture-resistant plate is located between the two frameworks to prevent puncture damage to the inner liner. Access to the cargo cavity is through two hinged, sealed closures in series at one end that are bolted in place during transport. Unit Transportation Costs for MRS/IS

The bases for the various elements of transportation costs are given in this section. The cost elements include shipping charges, special equipment and security charges, shipping container leasing fees, and demurrage fees. Total transport costs are provided at the end of this section.

The actual fee charged by a truck or rail carrier to transport spent fuel, high-level wastes, or transuranic wastes cannot be determined until a contract is negotiated. These charges are based on several conditions, including shipment origins and destinations, shipment weight, shipment size, 


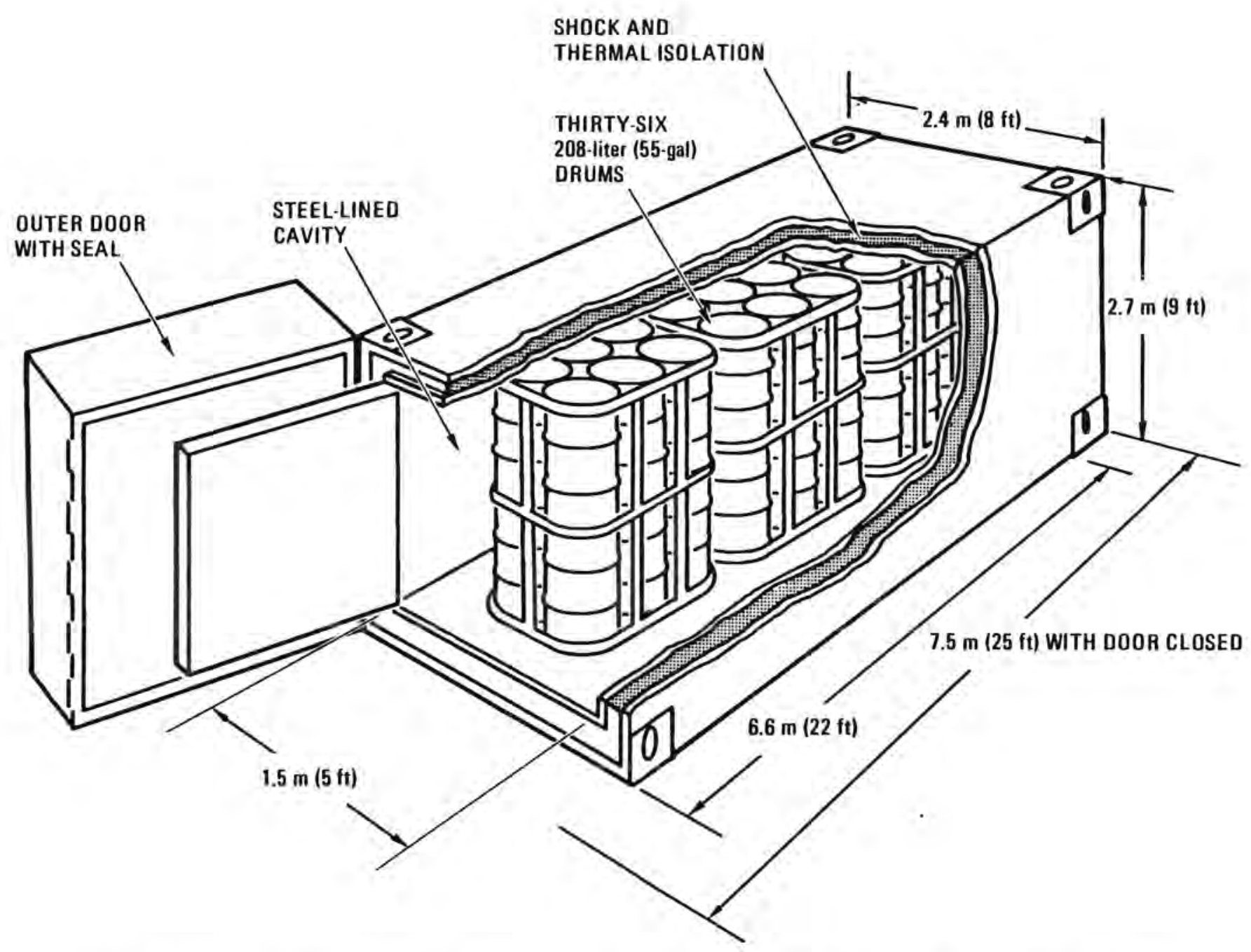

FIGURE C.8. TRUPACT Truck Version. One TRUPACT is shipped per rail truck and two are shipped per rail car. 
the route, volume shipped, frequency of shipments, and the existing competition. Fortunately, basic shipping charge structures for these materials do exist in various forms in the U.S. Shipping container rental fees are based on personal contacts with cask suppliers. The purpose of this report is to provide transportation unit costs for the aforementioned materials to be utilized in the preconceptual designs of MRS/IS facilities.

Charges for Shipments by Truck

The truck shipping charges included in this report are from a single carrier (Tri-State Motor Transit Co. 1981). This carrier services the 48 contiguous states and has the capability to comply with NRC requirements for shipping spent fuel. Since transportation requirements for spent fuel are the most stringent, it is expected that this carrier can also comply with the regulations for shipping $\mathrm{HL}$ and TRU waste. In addition, the use of a single carrier provides a uniform basis for calculating truck shipping charges.

Basic charges for shipping spent fuel and wastes with legal-weight and legal-dimension vehicles do not vary across the country. Basic weight and dimension charges for spent fuel, high-level wastes and transuranic wastes are shown in Table C.5.

In addition to the charges listed in Table C.5, other charges are imposed on shipments of spent fuel and potentially will be imposed on HLW shipments. If a shipment requires specially equipped vehicles and specially trained personnel, as specified in NRC regulations (10 CFR 73), an additional charge per loaded mile will be imposed on shipments. The regulations require that these shipments must be scheduled, in writing, at least seven days in advance. If a shipment is cancelled or rescheduled during that seven-aay period, a $\$ 1000$ fee is charged. When the carrier is required to furnish armed driver(s) or escort(s), an additional charge is assessed. If a separate escort vehicle is required or necessary, another fee is added to the shipping charge. 
TABLE C.5. Truck Shipping Charges for Spent Fuel and High-Level Wastes (Tri-State Motor Transit Co. 1981 (a)

Rates in Dollars per 100 Pounds(b)

\begin{tabular}{|c|c|c|c|c|c|}
\hline $\begin{array}{l}\text { Miles- } \\
\text { Not Over }\end{array}$ & Full & Empty & $\begin{array}{l}\text { Miles- } \\
\text { Not Over } \\
\end{array}$ & Full & Empty \\
\hline $\begin{array}{l}100 \\
110 \\
120 \\
130 \\
140\end{array}$ & $\begin{array}{l}1.52 \\
1.60 \\
1.61 \\
1.65 \\
1.71\end{array}$ & $\begin{array}{r}.98 \\
.99 \\
1.03 \\
1.06 \\
1.08\end{array}$ & $\begin{array}{r}950 \\
975 \\
1000 \\
1025 \\
1050\end{array}$ & $\begin{array}{l}4.68 \\
4.76 \\
4.84 \\
4.93 \\
5.10\end{array}$ & $\begin{array}{l}3.71 \\
3.81 \\
3.89 \\
4.01 \\
4.10\end{array}$ \\
\hline $\begin{array}{l}150 \\
160 \\
170 \\
180 \\
190\end{array}$ & $\begin{array}{l}1.77 \\
1.84 \\
1.90 \\
2.02 \\
2.07\end{array}$ & $\begin{array}{l}1.10 \\
1.11 \\
1.14 \\
1.17 \\
1.21\end{array}$ & $\begin{array}{l}1075 \\
1100 \\
1125 \\
1150 \\
1175\end{array}$ & $\begin{array}{l}5.20 \\
5.35 \\
5.45 \\
5.56 \\
5.72\end{array}$ & $\begin{array}{l}4.17 \\
4.27 \\
4.42 \\
4.48 \\
4.56\end{array}$ \\
\hline $\begin{array}{l}200 \\
225 \\
250 \\
275 \\
300\end{array}$ & $\begin{array}{l}2.16 \\
2.23 \\
2.35 \\
2.42 \\
2.49\end{array}$ & $\begin{array}{l}1.24 \\
1.31 \\
1.39 \\
1.40 \\
1.45\end{array}$ & $\begin{array}{l}1200 \\
1225 \\
1250 \\
1275 \\
1300\end{array}$ & $\begin{array}{l}5.80 \\
5.94 \\
6.07 \\
6.1 .9 \\
6.31\end{array}$ & $\begin{array}{l}4.68 \\
4.76 \\
4.87 \\
4.96 \\
5.08\end{array}$ \\
\hline $\begin{array}{l}325 \\
350 \\
375 \\
400 \\
425\end{array}$ & $\begin{array}{l}2.59 \\
2.68 \\
2.73 \\
2.83 \\
2.94\end{array}$ & $\begin{array}{l}1.56 \\
1.60 \\
1.61 \\
1.65 \\
1.77\end{array}$ & $\begin{array}{l}1325 \\
1350 \\
1375 \\
1400 \\
1425\end{array}$ & $\begin{array}{l}6.41 \\
6.57 \\
6.66 \\
6.79 \\
6.91\end{array}$ & $\begin{array}{l}5.15 \\
5.25 \\
5.36 \\
5.45 \\
5.54\end{array}$ \\
\hline $\begin{array}{l}450 \\
475 \\
500 \\
525 \\
550\end{array}$ & $\begin{array}{l}3.02 \\
3.09 \\
3.19 \\
3.24 \\
3.32\end{array}$ & $\begin{array}{l}1.82 \\
1.90 \\
1.97 \\
2.12 \\
2.20\end{array}$ & $\begin{array}{l}1450 \\
1475 \\
1500 \\
1525 \\
1550\end{array}$ & $\begin{array}{l}7.01 \\
7.17 \\
7.27 \\
7.38 \\
7.53\end{array}$ & $\begin{array}{l}5.63 \\
5.75 \\
5.82 \\
5.95 \\
6.05\end{array}$ \\
\hline $\begin{array}{l}575 \\
600 \\
625 \\
650 \\
675\end{array}$ & $\begin{array}{l}3.44 \\
3.51 \\
3.60 \\
3.67 \\
3.76\end{array}$ & $\begin{array}{l}2.29 \\
2.39 \\
2.50 \\
2.62 \\
2.66\end{array}$ & $\begin{array}{l}1575 \\
1600 \\
1625 \\
1650 \\
1675\end{array}$ & $\begin{array}{l}7.633 \\
7.77 \\
7.90 \\
7.98 \\
8.13\end{array}$ & $\begin{array}{l}6.12 \\
6.21 \\
6.33 \\
6.41 \\
6.52\end{array}$ \\
\hline $\begin{array}{l}700 \\
725 \\
750 \\
775 \\
800\end{array}$ & $\begin{array}{l}3.84 \\
3.93 \\
4.01 \\
4.08 \\
4.16\end{array}$ & $\begin{array}{l}2.72 \\
2.89 \\
2.98 \\
3.03 \\
3.11\end{array}$ & $\begin{array}{l}1700 \\
1725 \\
1750 \\
1775 \\
1800\end{array}$ & $\begin{array}{l}8.24 \\
8.35 \\
8.49 \\
8.59 \\
8.73\end{array}$ & $\begin{array}{l}6.61 \\
6.79 \\
6.87 \\
6.98 \\
7.11\end{array}$ \\
\hline
\end{tabular}


TABLE C.5 (contd)

Rates in Dollars per 100 Pounds (b)

\begin{tabular}{|c|c|c|c|c|c|}
\hline $\begin{array}{l}\text { Miles- } \\
\text { Not Over }\end{array}$ & Fu11 & Empty & $\begin{array}{l}\text { Miles- } \\
\text { Not Over } \\
\end{array}$ & Full & Empty \\
\hline $\begin{array}{l}825 \\
850 \\
875 \\
900 \\
925\end{array}$ & $\begin{array}{l}4.26 \\
4.31 \\
4.44 \\
4.49 \\
4.57\end{array}$ & $\begin{array}{l}3.22 \\
3.30 \\
3.39 \\
3.50 \\
3.63\end{array}$ & $\begin{array}{l}1825 \\
1850 \\
1875 \\
1900 \\
1925\end{array}$ & $\begin{array}{l}8.84 \\
8.96 \\
9.08 \\
9.23 \\
9.34\end{array}$ & $\begin{array}{l}7.17 \\
7.25 \\
7.37 \\
7.50 \\
7.57\end{array}$ \\
\hline $\begin{array}{l}1950 \\
1975 \\
2000 \\
2025 \\
2050\end{array}$ & $\begin{array}{l}9.43 \\
9.60 \\
9.68 \\
9.83 \\
9.94\end{array}$ & $\begin{array}{l}7.64 \\
7.76 \\
7.84 \\
7.93 \\
8.65\end{array}$ & $\begin{array}{l}3200 \\
3250 \\
3300 \\
3350 \\
3400\end{array}$ & $\begin{array}{l}15.53 \\
15.77 \\
16.02 \\
16.22 \\
16.49\end{array}$ & $\begin{array}{l}12.55 \\
12.78 \\
12.92 \\
13.14 \\
13.35\end{array}$ \\
\hline $\begin{array}{l}2075 \\
2100 \\
2125 \\
2150 \\
2175\end{array}$ & $\begin{array}{l}10.07 \\
10.19 \\
10.30 \\
10.40 \\
10.56\end{array}$ & $\begin{array}{l}8.16 \\
8.24 \\
8.32 \\
8.44 \\
8.53\end{array}$ & $\begin{array}{l}3450 \\
3500 \\
3550 \\
3600 \\
3650\end{array}$ & $\begin{array}{l}16.74 \\
16.98 \\
17.20 \\
17.45 \\
17.69\end{array}$ & $\begin{array}{l}13.53 \\
13.72 \\
13.91 \\
14.12 \\
14.33\end{array}$ \\
\hline $\begin{array}{l}2200 \\
2250 \\
2300 \\
2350 \\
2400\end{array}$ & $\begin{array}{l}10.67 \\
10.92 \\
11.16 \\
11.40 \\
11.65\end{array}$ & $\begin{array}{l}8.65 \\
8.82 \\
9.04 \\
9.23 \\
9.42\end{array}$ & $\begin{array}{l}3700 \\
3750 \\
3800 \\
3850 \\
3900\end{array}$ & $\begin{array}{l}17.95 \\
18.18 \\
18.42 \\
18.64 \\
18.92\end{array}$ & $\begin{array}{l}14.48 \\
14.74 \\
14.92 \\
15.11 \\
15.29\end{array}$ \\
\hline $\begin{array}{l}2450 \\
2500 \\
2550 \\
2600 \\
2650\end{array}$ & $\begin{array}{l}11.91 \\
12.10 \\
12.35 \\
12.60 \\
12.85\end{array}$ & $\begin{array}{r}9.62 \\
9.83 \\
10.00 \\
10.21 \\
10.39\end{array}$ & $\begin{array}{l}3050 \\
4000 \\
4050 \\
4100 \\
4150\end{array}$ & $\begin{array}{l}19.16 \\
19.41 \\
19.63 \\
19.87 \\
20.10\end{array}$ & $\begin{array}{l}15.50 \\
15.69 \\
15.92 \\
16.09 \\
16.29\end{array}$ \\
\hline $\begin{array}{l}2700 \\
2750 \\
2800 \\
2850 \\
2900\end{array}$ & $\begin{array}{l}13.09 \\
13.34 \\
13.57 \\
13.83 \\
14.05\end{array}$ & $\begin{array}{l}10.61 \\
10.77 \\
11.00 \\
11.18 \\
11.39\end{array}$ & $\begin{array}{l}4200 \\
4250 \\
4300\end{array}$ & $\begin{array}{l}20.38 \\
20.61 \\
20.84\end{array}$ & $\begin{array}{l}16.48 \\
16.65 \\
16.87\end{array}$ \\
\hline $\begin{array}{l}2950 \\
3000 \\
3050 \\
3100 \\
3150\end{array}$ & $\begin{array}{l}14.32 \\
14.52 \\
14.79 \\
15.03 \\
15.27\end{array}$ & $\begin{array}{l}11.53 \\
11.78 \\
11.96 \\
12.12 \\
12.32\end{array}$ & & & \\
\hline
\end{tabular}

(a) Updated April 22, 1982.

(b) Source: Tri-State Motor Transit Co., Docket MC-109397. Item No. 200, First Revision. 
NRC regulations (10 CFR 73) state that a spent fuel transport vehicle within a heavily populated area must be occupied by at least two individuals, one of whom serves as an escort. It must be escorted by an armed member of the local law enforcement agency or by a vehicle ahead and one behind, each of which contains at least one armed guard. A spent fuel transport vehicle not within heavily populated areas must be occupied by at least one driver and one escort, or occupied by one driver and escorted by a separate vehicle occupied by at least two escorts, or escorted as required for transport vehicles in heavily populated areas. It is not known at this time whether high-level waste shipments will require these security considerations, but such is assumed here. For this study, security costs are assumed to include one driver and one escort.

The Code of Federal Regulations does not reference security clearance requirements for drivers or escorts. However, if clearances are required, an additional charge will be assessed. These charges are not included in the transportation costs.

A fuel use surcharge was assessed in the past on top of all other charges and surcharges per shipment. This charge was adopted in 1979 when fuel costs became unstable. However, this surcharge has recently been incorporated into the basic shipping charges shown in Table C.5. Many other charges can apply if any deviations occur in the original route, schedule, delivery acceptance, or in-transit stops, but these are ignored in this study.

Summarized in Table C.6 are the additional fees or surcharges that are imposed on spent fuel shipments and assumed here to be imposed on HLW shipments.

A final fee charged by truck carriers is a charge for their equipment being idle at the terminal facilities while the shipping container is being loaded, unloaded, or held up by the facility operator. Drivers are assumed to deliver their shipment, wait for it to be unloaded, and then depart with the same shipping system they arrived with. Typically, this demurrage fee is negotiated prior to the shipment and the actual fee varies between contracts. 
TABLE C.6. Truck Surcharges for Spent Fuel and High-Leve 1 Waste Shipments

Type of Charge

Special equipment

Armed driver/escort

Separate escort vehicle

"L" cleared driver

"Q" cleared driver(c)

$\begin{array}{lc}\frac{\text { Cost }}{\text { \$0.92 per loaded mile }} & \frac{\text { NRC Requirement }}{x} \\ \text { \$0.20 per mile } & x \\ \$ 1.28 \text { per mile } & x^{(b)} \\ \text { \$0.12 per mile } & \\ \text { \$0.15 per mile } & \end{array}$

(a) Total miles are normally based on special equipment and personnel domiciled at Joplin, Missouri. Mileages are computed to point of origin of shipment, then through to the destination, then back to domicile point of shipment. Mileages to Joplin, Missouri, are not included for simplification purposes.

(b) Required in heavily populated areas.

(c) Each additional "Q" cleared driver is a fixed charge of $\$ 200$ per shipment.

This fee is assessed to compensate for idle equipment and the driver's wages and living expenses while the truck is not with a load. To keep additional calculations as simple as possible, the average fee per hour (based on 24 hours demurrage using a schedule from Tri-State Motor Transit Co., Docket No. MC-109397, Item No. 500) will be utilized. From this basis, the demurrage fee used in this study is $\$ 29.30$ per hour.

\section{Charges for Shipments by Rail}

Rail shipping charges are much more complicated than truck shipping charges. Rail charges are of ten not uniform with the distance traveled and can be affected by topography, state regulations, competition, and the route traveled. It is assumed in this study that Special Trains(a) will not be used, so the rail shipping charges that are developed are for general freight service.

(a) Special Trains are defined as trains made up solely for the shipment of one commodity or for one shipper. 
Shipping charges assessed by rail carriers are specific for each origin-destination combination. Each origin and destination lies in a particular "rate-basing area" which is a major rail point where branch lines connect to local towns or communities. The shipping charges are assessed for transporting a commodity between specific rate-basing areas, regardless of the route or mileages traveled. Therefore, there is no such thing as a "generic" rail shipping charge. Specific origin-destination combinations must be defined. To obtain meaningful cost numbers for this study, charges were obtained for transporting radioactive materials between the locations shown in Table C.7. Shipping charges are the same regardless of the direction the materials were being transported; i.e., east to west or west to east. Also shown on this table are the approximate mileages between each location and the approximate transit times. Note that in some cases, especially in long hauls, the mileages and charges quoted may be the same for two different shipment origins. This is because shipping charges are established between rate-basing areas regardless of the route or distance traveled. The rail transit times are the hardest to define with any certainty. Too many variables are involved between any origin/destination combination to obtain a precise value. The times reported in Table C.7 are based on past experience and judgment for the areas and/or routes involved.

The charges for general freight service for spent fuel and HL and TRU wastes are somewhat uniform when based on the mileages shown in Table $C .7$. Curves showing the shipping charges (per $100 \mathrm{lb}$ ) as a function of one-way miles are shown in Figure C.9 for loaded and empty containers. Minor variations are evident between shipments entirely within the East and entirely within the West. It appears that western shipments have higher charges, but there are too few data points to establish a conclusive pattern.

Rail shipments of spent fuel require security provisions as do truck shipments. Rail shipments within heavily populated areas must be accompanied by two armed escorts that may or may not be members of a local law enforcement agency. A shipment not within a heavily populated area must be accompanied by at least one escort (10 CFR 73). 
TABLE C.7. Rail Shipping Charges, Distances, and Transit Times for Several Origin/Destination Combinations

\begin{tabular}{|c|c|c|c|c|c|}
\hline $\begin{array}{c}\text { From } \\
\text { (Origin) } \\
\end{array}$ & $\begin{array}{c}\text { To } \\
\text { (Destination) } \\
\end{array}$ & $\begin{array}{c}\text { Dolla } \\
100 \\
\text { Loaded } \\
\end{array}$ & $\begin{array}{c}\text { per } \\
\text { unds } \\
\text { Empty }\end{array}$ & $\begin{array}{c}\text { Approximate } \\
\text { One-way } \\
\text { Mileages } \\
\end{array}$ & $\begin{array}{c}\text { Approximate } \\
\text { One-way } \\
\text { Transit Time } \\
\text { (Days) } \\
\end{array}$ \\
\hline Hanford, WA & Barnwell, SC & 16.89 & 15.83 & 2700 & $12-15$ \\
\hline Mercury, NV & Barnwel1, SC & 16.89 & 15.83 & 2200 & $10-13$ \\
\hline Berwick, PA & Barnwe11, SC & 7.13 & 6.69 & 750 & $5-7$ \\
\hline Palo, IA & Barnwell, SC & 8.82 & 8.27 & 1050 & $9-12$ \\
\hline Port Gibson, MS & Barnwel1, SC & 6.79 & 6.37 & 700 & $6-8$ \\
\hline Waterford, CT & Barnwe11, SC & 7.88 & 7.39 & 900 & $8-11$ \\
\hline Eureka, CA & Barnwel1, SC & 19.15 & 17.95 & 2950 & $12-15$ \\
\hline Hanford, WA & Mercury, NV & 11.09 & 10.40 & 1000 & $9-12$ \\
\hline Berwick, PA & Mercury, NV & 16.89 & 15.83 & 2400 & $12-15$ \\
\hline Palo, IA & Mercury, NV & 13.39 & 12.55 & 1500 & $10-13$ \\
\hline Port Gibson, MS & Mercury, NV & 14.78 & 13.86 & 1600 & $10-13$ \\
\hline Waterford, CT & Mercury, NV & 16.89 & 15.83 & 2650 & $12-15$ \\
\hline Eureka, CA & Mercury, NV & 9.25 & 8.67 & 800 & $7-9$ \\
\hline Rainier, OR & Hanford, WA & 5.22 & 4.90 & 300 & $3-5$ \\
\hline Satsop, WA & Hanford, WA & 5.03 & 4.72 & 350 & $4-7$ \\
\hline Eureka, CA & Hanford, WA & 10.86 & 10.18 & 1200 & $7-9$ \\
\hline
\end{tabular}

Source: Personal communication with Mr. Frank Votaw, Rockwell, Hanford Operations, Traffic Division, Motor Rates and Routes.

Rail carriers have no provisions to supply an armed escort service, and it is expected that this service will be provided by the shipper. Rail carriers have indicated they will supply a car or caboose for the escorts to ride in. The charge for this service would be the price of a coach-class passenger ticket, or approximately 9 cents per mile per escort. (a)

(a) B. M. Cole. 1981. Shipping Charges for LWR Spent Fuel (letter report to John Cashwe11, Sandia National Laboratories). Pacific Northwest Laboratory, Richland, Washington. 


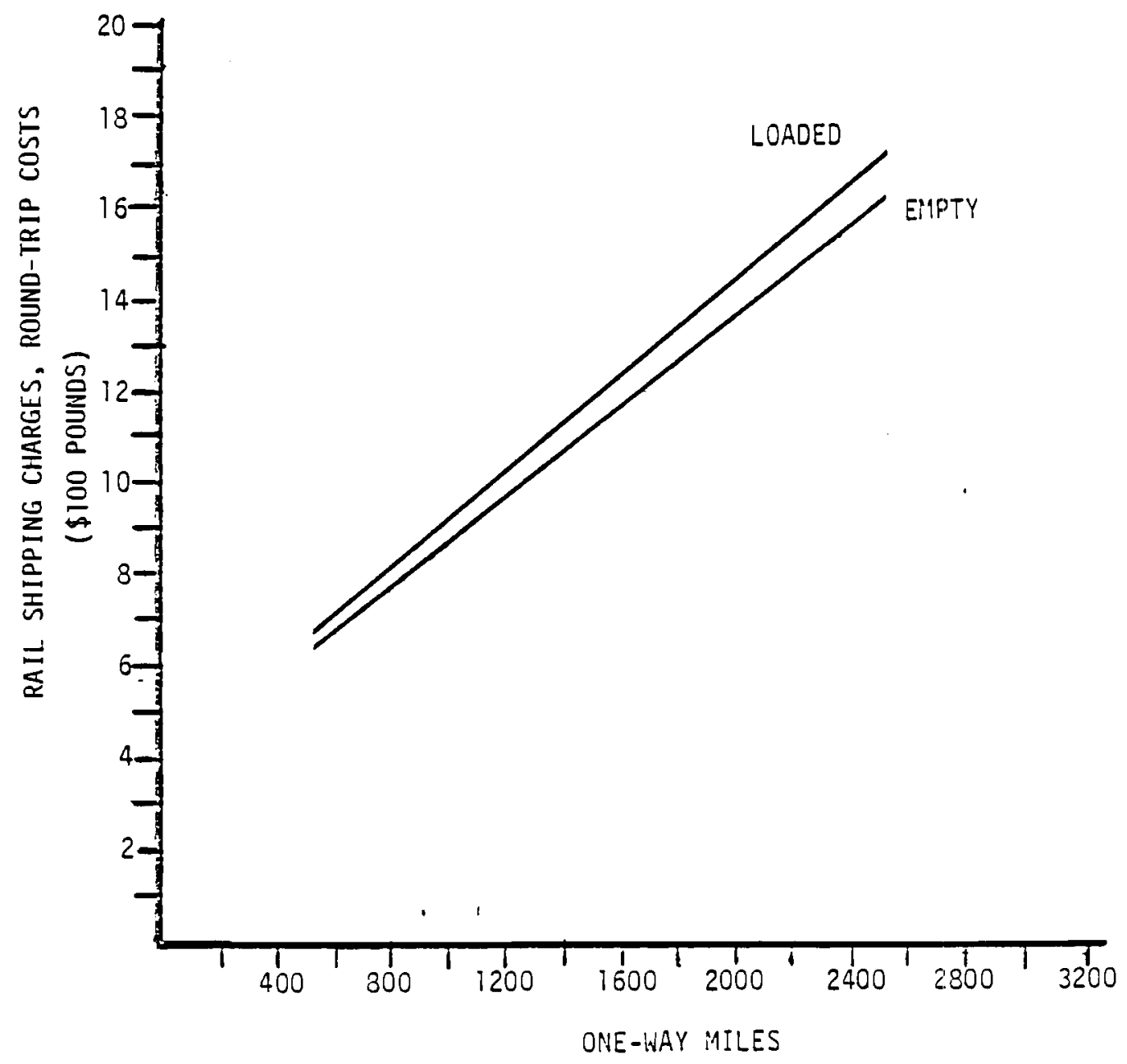

FIGURE C.9. Rail Shipping Charges for Loaded and Empty Shipments

The total security costs must also include the wages and living expenses of the escorts. The charge for rail escorts can be estimated by using the truck charge of 20 cents per mile as an index. A truck with two drivers can travel about 900 miles in one day. The salary and expenses per escort is thus $\$ 180$ per day. At least two escorts per trip are required so that the shipment can be constantly under surveillance. Using the approximate mileages and transit times shown in Table C.7, the average distance travelled per day by rail is 119 miles, which works out to an average speed of 5 miles per hour. 
This average makes the charge for rail escort service about $\$ 1.50$ per escort per mile or $\$ 3.00$ per mile for continuous surveillance. Adding the cost of the coach-class passenger ticket for each escort brings the total for rail escort service to about $\$ 3.18$ per mile.

Demurrage charges for rail shipments are included in the shipping system rental fees. This is because there are no guards or drivers who must wait for the shipping system to be loaded or unloaded. Demurrage charges for the transport vehicle (rail car or flatbed trailer) are included in the rental fees.

\section{Shipping Container Rental Fees}

One basis for this study is that transportation services for spent fuel, HL and TRU wastes will be supplied by private industry as a commercial venture. Therefore, the total transportation costs must include a fee for rental or lease of the shipping containers from their suppliers. These additional costs include operating costs, amortization of transport hardware, and profits. These costs would be calculated differently if, in the future, the U.S. Government decides to procure and operate its own transportation hardware.

Rental fees charged by shipping container suppliers are a negotiable item that can vary in each contract. These cask use and service charges include some field services, training, and maintenance of equipment in addition to operating and amortization costs and profits. Typical rental fees for the shipping system used in this study were obtained from contacts with the supplier companies. The reference rental fees are shown in Table C.8. Use and service charges for conceptual transportation equipment (i.e., HLW-T, $H L W-R$, and TRUPACT) are assumed to be the same portion of the capital costs as those for the equipment currently in use. It should be noted that the use and service charges shown in Table C.8 are based on short-term leases and are not the charges that would be assessed if the shipping containers were leased for a year or longer. Long-term use of shipping containers would result in significantly lower use and service charges than those shown in Table C.8. 
TABLE C.8. Shipping Container Rental and Service Charges (Mid-1982 Dollars)

\begin{tabular}{|c|c|c|c|}
\hline & & \multicolumn{2}{|c|}{ Single Shipment Cost, $\$$} \\
\hline Shipping Container & Charge, \$/Day & 500 One-Way Miles & 2500 One-Way Miles \\
\hline G.E. IF-300 & $5,750(a)$ & 57,500 & 184,000 \\
\hline NAC-1 & 2,000 (b) & 6,000 & 16,000 \\
\hline$H L W-T$ & $1,750(c)$ & 5,250 & 14,000 \\
\hline$H L W-R$ & $4,375(d)$ & 43,750 & 140,000 \\
\hline CNS-7-100 & $175 /$ container & $\begin{array}{l}525(T)(f) \text { and } \\
5250(R)\end{array}$ & $\begin{array}{l}1,400(T) \text { and } \\
16,800(R)\end{array}$ \\
\hline CNS-14-170 & $75 /$ container & $\begin{array}{l}525(T) \text { and } \\
5,250(R)\end{array}$ & $1400(T)$ and \\
\hline TRUPACT & $700 /$ container $(e)$ & $\begin{array}{l}2,100(T) \text { and } \\
14,000(R)\end{array}$ & $\begin{array}{l}5,600(T) \\
44,800(R)\end{array}$ \\
\hline
\end{tabular}

(a) Based on truck and round-trip transit times of 3 and 8 days and rail transit times of 10 and 32 days for 500 and 2500 one-way mile trips, respectively.

(b) Calculated from first 30 days of use in schedule below:

\begin{tabular}{ccc} 
No. Days of Use & & Charge \\
\hline $1-10$ & & 30,000 \\
$11-30$ & ADD & $1500 /$ day \\
$31-90$ & ADD & $1100 /$ day \\
$91-180$ & ADD & $900 /$ day \\
over 180 & ADD & $800 /$ day
\end{tabular}

(c) Fabrication costs for HLW-T cask are estimated at about $\$ 1 M$. This is a conceptual cask system, and rental fees have not been calculated. The value in this table was calculated as follows. The estimated fabrication costs of the CNS-14-170 is $\$ 100,000$. Assume the same ratio of fabrication costs to rental fee for HLW-T cask.

(d) Fabrication costs for HLW-R cask are estimated at about \$2.5 M. See footnote (c) for rental fee calculation.

(e) Fabrication costs for TRUPACT are estimated at about $\$ 400,000$. See footnote (c) for rental fee calculation.

(f) $(T)=\operatorname{Truck},(R)=$ Rail. 
One factor that may tend to balance this effect is that the rental fees reported do not include fabrication of new equipment (that is, these fees are based partially on recovering the capital costs of equipment fabricated several years ago). The costs of fabricating new equipment have increased significantly, and therefore the rental fees charged by suppliers will most likely increase.

\section{Calculation of Unit Transportation Costs}

The final information required for transportation costs is the average weights of shipments or the average commodity (i.e., waste plus canister) unit weights. For the materials in this study, the average commodity unit weights are expressed in kilograms. Transportation unit costs will be expressed primarily in dollars per shipment for each type of waste and shipping system.

The average commodity unit weights for the high-level waste, RH-TRU waste special canister, and RHTRU waste drum shipping containers are straightforward because they haul only a single type of waste container. Their average commodity unit weights are calculated by multiplying the capacity of the shipping containers (see Table C.4) by the average weights of the loaded waste canisters (see Table C.3). To develop the average commodity unit weight for spent fuel truck shipments, the information in Tables C.3 and C.4 is used. Also, since about two-thirds of the commercial reactors are PWRs, an estimated two-thirds of the shipments will be PWR fuel elements. This ratio provides an average commodity weight of $628 \mathrm{~kg}(1385 \mathrm{lb})$ for truck shipments and $4775 \mathrm{~kg}$ $(10,500$ lb) for rail shipments. Similar procedures were used to calculate the average commodity weights for the TRUPACT. The ratio of drum shipments to box shipments was calculated from data derived by Fletcher (a) from estimates of waste quantities and characteristics from the Barnwell Nuclear Fuel Plant. (b) The average commodity weights and empty and loaded shipping container weights used to calculate transportation unit costs are shown in Table C.9.

(a) See Appendix B.

(b) W. H. Carr (Draft). 1982. Estimation of Waste Types, Characteristics, and Quantities from the Barnwell Nuclear Fuel Plant. ONWI/3092/TOP-01. Allied-General Nuclear Services, Barnwell, South Carolina. 
TABLE C.9. Average Commodity Weights and Empty and Loaded Shipping Container Weights Used In Transportation Unit Cost Calculations

\begin{tabular}{|c|c|c|c|}
\hline \multirow{2}{*}{$\begin{array}{c}\text { Material/ } \\
\text { Shipping Container }\end{array}$} & \multirow{2}{*}{$\begin{array}{l}\text { Average } \\
\text { Commodity } \\
\text { Weight, } \\
\mathrm{kg} / \text { Shipment } \\
\end{array}$} & \multicolumn{2}{|c|}{$\begin{array}{c}\text { Shipping Container } \\
\text { Weight, } \mathrm{kg}\end{array}$} \\
\hline & & Empty & Loaded \\
\hline $\begin{array}{l}\text { Spent fuel } \\
\text { IF-300 } \\
\text { NAC-1 }\end{array}$ & $\begin{array}{r}4,775 \\
628\end{array}$ & $\begin{array}{l}63,490 \\
22,660\end{array}$ & $\begin{array}{l}68,265 \\
23,288\end{array}$ \\
\hline $\begin{array}{l}\text { High-level wastes } \\
\text { IF-300 } \\
\text { NAC-1 }\end{array}$ & $\begin{array}{l}5,250 \\
1,050\end{array}$ & $\begin{array}{l}63,490 \\
22,660\end{array}$ & $\begin{array}{l}68,740 \\
23,710\end{array}$ \\
\hline $\begin{array}{l}\text { RHTRU canisters } \\
\text { HLW-R } \\
\text { HLW-T }\end{array}$ & $\begin{array}{r}17,500 \\
3,500\end{array}$ & $\begin{array}{l}52,150 \\
11,700\end{array}$ & $\begin{array}{l}69,650 \\
15,200\end{array}$ \\
\hline $\begin{aligned} \text { RHTRU drums }(<5 \mathrm{R} / \mathrm{hr}) \\
\text { CNS } 14-170(\mathrm{R})(\mathrm{a}) \\
\text { CNS } 14-170(\mathrm{~T})\end{aligned}$ & $\begin{array}{r}12,600 \\
4,200\end{array}$ & $\begin{array}{l}46,200 \\
15,400\end{array}$ & $\begin{array}{l}58,800 \\
19,600\end{array}$ \\
\hline $\begin{aligned} \text { RHTRU drums }(>5 R / h r) \\
\text { CNS } 7-100(\mathrm{R}) \\
\text { CNS 7-100 (T) }\end{aligned}$ & $\begin{array}{l}6,300 \\
2,100\end{array}$ & $\begin{array}{l}48,300 \\
26,100\end{array}$ & $\begin{array}{l}54,600 \\
18,200\end{array}$ \\
\hline $\begin{array}{l}\text { CHTRU wastes } \\
\text { TRUPACT (R) (b) } \\
\text { TRUPACT (T) }\end{array}$ & $\begin{array}{r}21,950 \\
9,610\end{array}$ & $\begin{array}{l}20,000 \\
10,000\end{array}$ & $\begin{array}{l}41,950 \\
19,610\end{array}$ \\
\hline
\end{tabular}

(a) Rail version consists of three shipping containers, transported on a railcar. Reported weights include this factor.

(b) Two TRUPACTs shipped per railcar. Reported weights include this factor.

Figures $C .10$ and $C .11$ show the transportation costs for each type of shipment under consideration in this study for truck and rail shipments, respectively. Each curve represents a different type of shipment. All curves represent the sum of the truck or rail shipping charges, cask use and service charges, and security costs (if applicable). These curves were drawn by plotting two points, one at $800 \mathrm{~km}$ (500 miles) and one at $4000 \mathrm{~km}$ (2500 miles). 


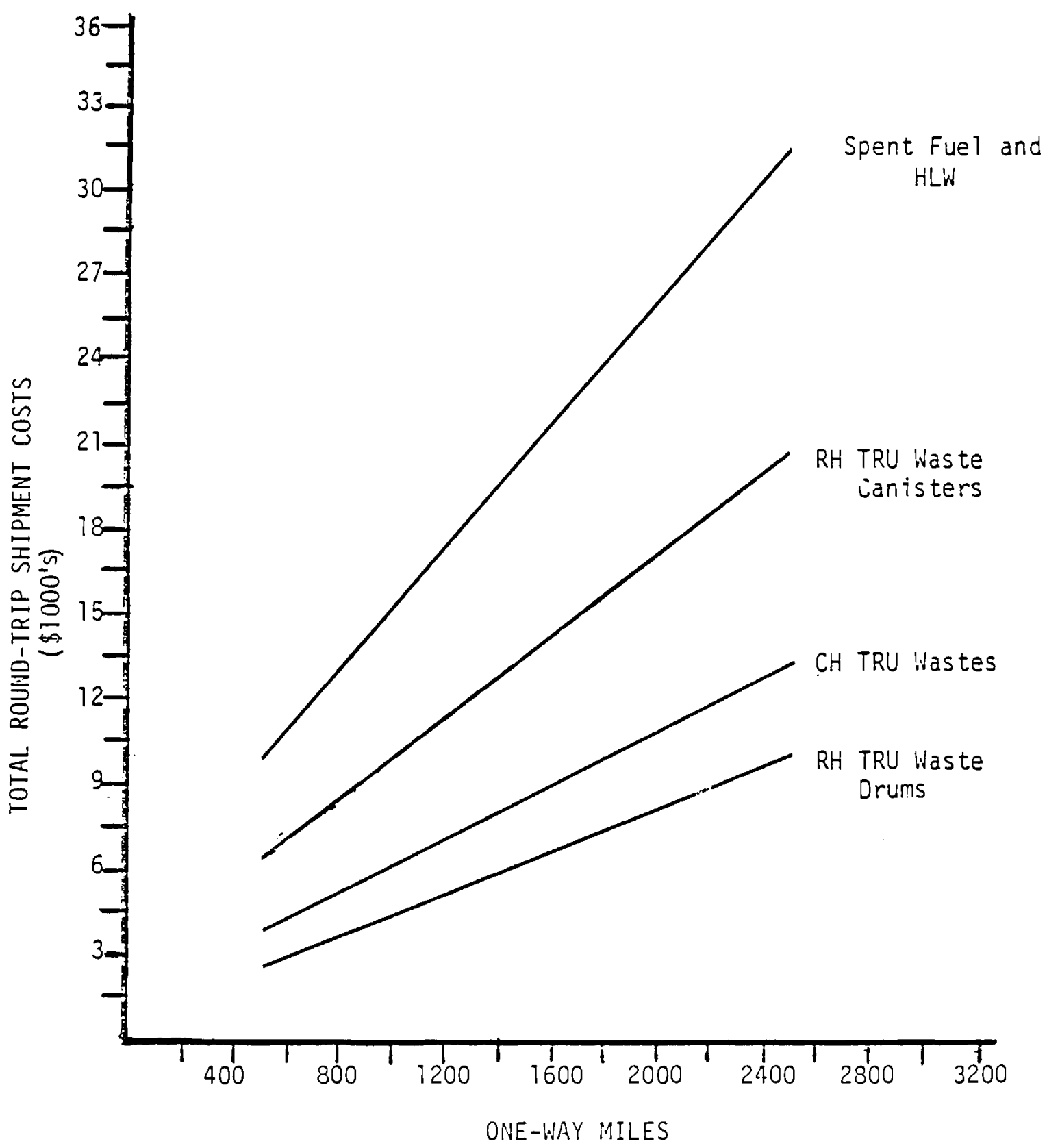

FIGURE C.10. Transportation Costs for Shipping Spent Fuel, High-Level and Transuranic Wastes by Truck 


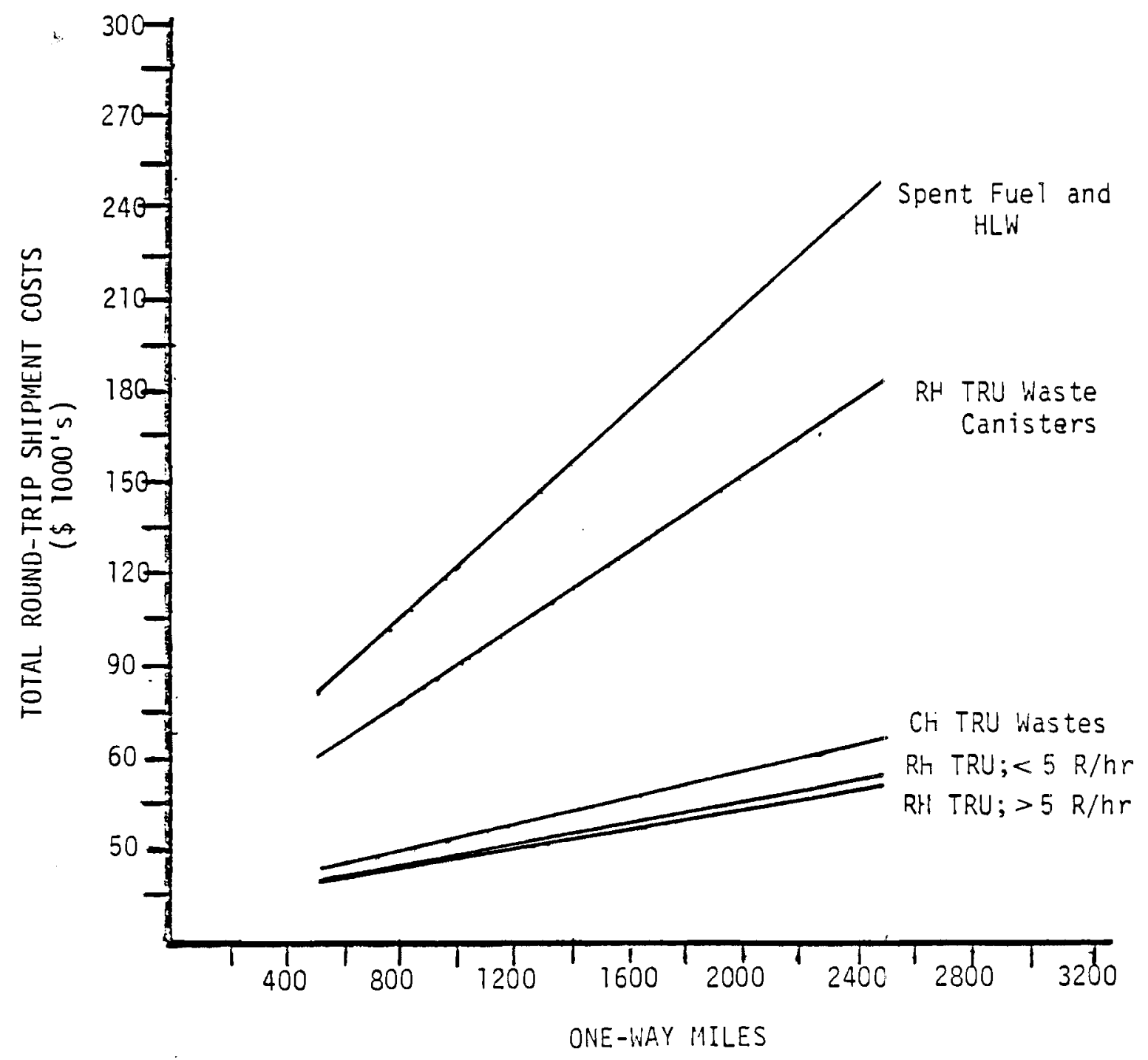

FIGURE C.11. Transportation Costs for Shipping Spent Fuel, High-Level and Transuranic Wastes by Rail 
Therefore the uncertainty of these curves increases with the distance along the curve from these points. Care must be taken when using these data due to the many assumptions and uncertainties outlined throughout the text. Note that the unit transportation costs in these figures are the costs per shipment. To convert these costs to dollars per kilogram (waste plus canister), the appropriate factors can be found in Table C.5. Demurrage charges for truck shipments must be added to the total shipments costs by applying the charge rate previously reported to the facility turnaround times.

Special equipment charges and security costs are included in the curves for spent fuel and high-level waste shipping costs. If these additional charges are later determined to be not required for high-level waste shipments, the transportation costs for truck shipments would be reduced by 14 percent and 19 percent for 500 mile and 2500 mile one-way trips, respectively. The corresponding reductions in rail costs for 500 ano 2500 one-way mile trips are 5 percent and 7 percent, respectively.

\section{C.2 COST ESTIMATES FOR SPECIFIC SCENARIOS}

The transportation costs developed for the MRS/IS facility co-located with a repository are presented in this appendix. The transportation costs are assessed only for offsite shipments, i.e., costs for onsite transfer of wastes from the MRS/IS facility to the disposal repository are not included. Throughput quantities for each of the waste forms considered in this study are obtained from Appendix B. The calculated throughput volumes are shown in Tables C.10 to C.14 for each fuel cycle scenario. Transportation unit cost data are from Subsection 3.5 of the main report. These data are used to develop the transportation costs for each year of MRS/IS facility operation.

The annual throughputs presented in Tables C.10 through C.14 are summed to provide the cumulative waste form storage requirements for the MRS/IS facility, for each scenario, in Tables C.15 through C.19.

The procedure used to calculate MRS/IS facility transportation costs is as follows. First, the waste throughput rates are converted to the number of truck and rail shipments of each waste form required to transport the 
throughput quantity. It is assumed that approximately 50 percent of the volume of each waste form is transported by truck and 50 percent by rail. The total number of shipments (truck plus rail) is minimized by filling the rail shipments to their maximum capacities first and then transporting the remainder by truck. This is done simply by dividing the annual throughput volume for each waste type by 2 (50 percent shipping mode split), dividing this volume by the single rail shipment capacity and rounding the number of rail shipments to the next largest whole number. The remaining volume is shipped by truck. Thus, somewhat more than 50 percent of the waste volumes are shipped by rail in these calculations. These data are shown in Tables C.20 to C.24 for each of the fuel cycle scenarios in this study.

The final step in the transportation cost calculations is to convert the annual number of offsite shipments in Tables C.20 to C.24 to annual transportation costs. This is done by multiplying the number of shipments by the unit cost per shipment developed for this study shown in Tables $C .25$ and C.26. It is assumed that the average turnaround time for a truck shipment is 24 hours and that for a rail shipment is 48 hours (required for demurrage fee calculations). The annual transportation costs for each waste form in mid-1982 dollars are shown in Tables C.27 to C.31 for each fuel cycle scenario. All transport distances are assumed to be 2500 miles, one-way, except for the spent fuel shipped to the MRS/IS facility. There, distances of 2000 miles and 2500 miles, one-way, were assumed. 
TABLE C.10. Annual Waste Form Processing Requirements at MRS/IS Handling Facility - Reference Scenario (Packages)

\begin{tabular}{|c|c|c|c|c|c|c|c|c|}
\hline \multirow{2}{*}{ Year } & \multicolumn{2}{|c|}{$\begin{array}{l}\text { Spent Fuel } \\
\text { Assembl ies }\end{array}$} & \multirow{2}{*}{$\begin{array}{c}H L W \\
\text { Canisters } \\
\end{array}$} & \multirow{2}{*}{$\begin{array}{c}\text { RH-TRU } \\
\text { Canisters } \\
\end{array}$} & \multicolumn{2}{|c|}{ Drums } & \multirow{2}{*}{$\begin{array}{l}\text { CH-TRU } \\
\text { Drums } \\
\end{array}$} & \multirow{2}{*}{$\begin{array}{l}\text { CH-TRU } \\
\text { Boxes }\end{array}$} \\
\hline & $\underline{B W R}$ & PWR & & & $\leq 5 \mathrm{R} / \mathrm{hr}$ & $\geq 5 \mathrm{R} / \mathrm{hr}$ & & \\
\hline 1990 & & & 233 & 183 & 205 & 28 & 1623 & 13 \\
\hline 1991 & 0 & & 467 & 368 & 410 & 55 & 3245 & 27 \\
\hline 1992 & 0 & 0 & 700 & 549 & 614 & 84 & 4868 & 41 \\
\hline 1993 & 0 & 0 & 700 & 549 & 614 & 84. & 4868 & 41 \\
\hline 1994 & 0 & 0 & 700 & 549 & 614 & 84 & 4868 & 41 \\
\hline 1995 & 0 & 0 & 700 & 549 & 614 & 84 & 4868 & 41 \\
\hline 1996 & 0 & 0 & 700 & 549 & 614 & 84 & 4868 & 41 \\
\hline 1997 & 0 & 0 & 700 & 549 & 614 & 84 & 4868 & 41 \\
\hline 1998 & 0 & 0 & 0 & 0 & 0 & 0 & 0 & 0 \\
\hline 1999 & 0 & 0 & 0 & 0 & 0 & 0 & 0 & 0 \\
\hline 2000 & 0 & 0 & 0 & 0 & 0 & 0 & 0 & 0 \\
\hline 2001 & 0 & 0 & 93 & 0 & 0 & 0 & 0 & 0 \\
\hline 2002 & 0 & 0 & 0 & 0 & 0 & 0 & 0 & 0 \\
\hline 2003 & 0 & 0 & 0 & 0 & 0 & 0 & 0 & 0 \\
\hline 2004 & 0 & 0 & 0 & 0 & 0 & 0 & 0 & 0 \\
\hline 2005 & 0 & 0 & 0 & 0 & 0 & 0 & 0 & 55 \\
\hline 2006 & 0 & 0 & 0 & 0 & 0 & 0 & 0 & 0 \\
\hline 2007 & 0 & 0 & 0 & 0 & 0 & 0 & 0 & 0 \\
\hline 2008 & 0 & 0 & 0 & 0 & 0 & 0 & 0 & 0 \\
\hline 2009 & 0 & 0 & 0 & 0 & 0 & 0 & 0 & 0 \\
\hline 2010 & 0 & 0 & 0 & 0 & 0 & 0 & 0 & $c$ \\
\hline 2011 & 0 & 0 & 467 & 37 & 41 & 6 & 325 & 3 \\
\hline 2012 & 0 & 0 & 233 & 0 & 0 & 0 & 0 & 0 \\
\hline 2013 & 0 & 0 & 420 & 220 & 246 & 34 & 1947 & 16 \\
\hline 2014 & 0 & 0 & 700 & 220 & 246 & 34 & 1947 & 16 \\
\hline 2015 & 0 & 0 & 0 & 0 & 0 & 0 & 0 & 0 \\
\hline 2016 & 0 & 0 & 0 & 0 & 0 & 0 & 0 & 0 \\
\hline 2017 & 0 & 0 & 0 & 0 & 0 & 0 & 0 & 0 \\
\hline 2018 & 0 & 0 & 0 & 0 & 0 & 0 & 0 & 0 \\
\hline 2019 & 0 & 0 & 0 & 0 & 0 & 0 & 0 & 0 \\
\hline 2020 & 0 & 0 & 0 & 0 & 0 & 0 & 0 & 0 \\
\hline
\end{tabular}

NOTE: Positive number denotes incoming shipment, negative number denotes outgoing shipment. 
TABLE C.11. Annual Waste Form Processing Requirements of the MRS/IS Facility - Delayed Reprocessing Scenario (Packages)

\begin{tabular}{|c|c|c|c|c|c|c|c|c|}
\hline \multirow[b]{2}{*}{ Year } & \multicolumn{2}{|c|}{$\begin{array}{l}\text { Spent Fue } 1 \\
\text { Assemblies }\end{array}$} & \multirow{2}{*}{$\begin{array}{c}\mathrm{HLW} \\
\text { Canisters } \\
\end{array}$} & \multirow{2}{*}{$\begin{array}{c}\text { RH-TRU } \\
\text { Canisters } \\
\end{array}$} & \multicolumn{2}{|c|}{ Drums } & \multirow{2}{*}{$\begin{array}{l}\mathrm{CH}-\mathrm{TRU} \\
\text { Drums } \\
\end{array}$} & \multirow{2}{*}{$\begin{array}{l}\text { CH-TRU } \\
\text { Boxes } \\
\end{array}$} \\
\hline & BWR & PWR & & & $\leq 5 \mathrm{R} / \mathrm{hr}$ & $>5 \mathrm{R} / \mathrm{hr}$ & & \\
\hline 1990 & 933 & 698 & 0 & 0 & 0 & 0 & 0 & 0 \\
\hline 1991 & 1839 & 459 & 0 & 0 & 0 & 0 & 0 & 0 \\
\hline 1992 & 1378 & 947 & 0 & 0 & 0 & 0 & 0 & 0 \\
\hline 1993 & 1300 & 1036 & 0 & 0 & 0 & 0 & 0 & 0 \\
\hline 1994 & 2155 & 1458 & 0 & 0 & 0 & 0 & 0 & 0 \\
\hline 1995 & 1961 & 2138 & 0 & 0 & 0 & 0 & 0 & 0 \\
\hline 1996 & 2878 & 2335 & 0 & 0 & 0 & 0 & 0 & 0 \\
\hline 1997 & 3322 & 2143 & 0 & 0 & 0 & 0 & 0 & 0 \\
\hline 1998 & & & 0 & 0 & 0 & 0 & 0 & 0 \\
\hline 1999 & 0 & 0 & 0 & 0 & 0 & 0 & 0 & 0 \\
\hline 2000 & 0 & 0 & 0 & 0 & 0 & 0 & 0 & 0 \\
\hline 2001 & 0 & 0 & 43 & 0 & 0 & 0 & 0 & 0 \\
\hline 2002 & 0 & 0 & 0 & 0 & 0 & 0 & 0 & 0 \\
\hline 2003 & 0 & 0 & 0 & 0 & 0 & 0 & 0 & 0 \\
\hline 2004 & 0 & 0 & 0 & 0 & 0 & 0 & 0 & 0 \\
\hline 2005 & 0 & 0 & 0 & 0 & 0 & 0 & 0 & 0 \\
\hline 2006 & 0 & 0 & 0 & 0 & 0 & 0 & 0 & 0 \\
\hline 2007 & 0 & 0 & 0 & 0 & 0 & 0 & 0 & 0 \\
\hline 2008 & 0 & 0 & 0 & 0 & 0 & 0 & 0 & 0 \\
\hline 2009 & 0 & 0 & 0 & 0 & 0 & 0 & 0 & 0 \\
\hline 2010 & 0 & 0 & 0 & 0 & 0 & 0 & 0 & 0 \\
\hline 2011 & 0 & 0 & 0 & 0 & 0 & 0 & 0 & 0 \\
\hline 2012 & -1022 & -1052 & 0 & 0 & 0 & 0 & 0 & 0 \\
\hline 2013 & -434 & -995 & 0 & 0 & 0 & 0 & 0 & 0 \\
\hline 2014 & -1739 & -1343 & 0 & 0 & 0 & 0 & 0 & 0 \\
\hline 2015 & -3822 & -2626 & 0 & 0 & 0 & 0 & 0 & 0 \\
\hline 2016 & -5350 & -4240 & 0 & 0 & 0 & 0 & 0 & 0 \\
\hline 2017 & -3400 & -958 & 0 & 0 & 0 & 0 & 0 & 0 \\
\hline 2018 & & & & & & & & \\
\hline 2019 & & & & & & & & \\
\hline 2020 & & & & & & & & \\
\hline
\end{tabular}

NOTE: Positive number denotes incoming shipment, negative number denotes outgoing shipment. 
TABLE C.12. Annual Waste Form Processing Requirements at MRS/IS Handling Facility - Delayed Disposal Scenario (Packages)

\begin{tabular}{|c|c|c|c|c|c|c|c|c|}
\hline \multirow{2}{*}{ Year } & \multicolumn{2}{|c|}{ Spent Fuel } & \multirow{2}{*}{$\begin{array}{c}H L W \\
\text { Canisters } \\
\end{array}$} & \multirow{2}{*}{$\begin{array}{c}\text { RH-TRU } \\
\text { Canisters } \\
\end{array}$} & \multicolumn{2}{|c|}{ Drums } & \multirow{2}{*}{$\begin{array}{l}\text { CH-TRU } \\
\text { Drums } \\
\end{array}$} & \multirow{2}{*}{$\begin{array}{l}\text { CH-TRU } \\
\text { Boxes }\end{array}$} \\
\hline & $\underline{B W R}$ & PWR & & & $\leq 5 R / h r$ & $\geq 5 \mathrm{R} / \mathrm{hr}$ & & \\
\hline 1990 & & & 233 & 183 & 205 & 28 & 1623 & 13 \\
\hline 1991 & 0 & & 467 & 368 & 410 & 55 & 3245 & 27 \\
\hline 1992 & 0 & 0 & 700 & 549 & 614 & 84 & 4868 & 41 \\
\hline 1993 & 0 & 0 & 700 & 549 & 614 & 84 & 4868 & 41 \\
\hline 1994 & 0 & 0 & 700 & 549 & 614 & 84 & 4868 & 41 \\
\hline 1995 & 0 & 0 & 700 & 549 & 614 & 84 & 4868 & 41 \\
\hline 1996 & 0 & 0 & 700 & 549 & 614 & 84 & 4868 & 41 \\
\hline 1997 & 0 & 0 & 700 & 549 & 614 & 84 & 4868 & 41 \\
\hline 1998 & 0 & 0 & 700 & 549 & 614 & 84 & 4868 & 41 \\
\hline 1999 & 0 & 0 & 700 & 549 & 614 & 84 & 4868 & 41 \\
\hline 2000 & 0 & 0 & 700 & 549 & 614 & 84 & 4868 & 41 \\
\hline 2001 & 0 & 0 & 993 & 732 & 818 & 112 & 6490 & 54 \\
\hline 2002 & 0 & 0 & 1167 & 915 & 1023 & 140 & 8113 & 68 \\
\hline 2003 & 0 & 0 & 1400 & 1098 & 1228 & 168 & 8552 & 81 \\
\hline 2004 & 0 & 0 & 1400 & 1098 & 1228 & 168 & 8552 & 81 \\
\hline 2005 & 0 & 0 & 1400 & 1098 & 1228 & 168 & 8552 & 81 \\
\hline 2006 & 0 & 0 & 1867 & 1464 & 1638 & 223 & 12,981 & 109 \\
\hline 2007 & 0 & 0 & 2334 & 1830 & 2048 & 279 & 16,227 & 135 \\
\hline 2008 & 0 & 0 & 1960 & 1438 & 1609 & 219 & 12,755 & 106 \\
\hline 2009 & 0 & 0 & 1960 & 1438 & 1609 & 219 & 12,755 & 106 \\
\hline 2010 & 0 & 0 & 1960 & 1438 & 1609 & 219 & 12,755 & 106 \\
\hline 2011 & 0 & 0 & 2427 & 1805 & 2019 & 275 & 16,000 & 134 \\
\hline 2012 & 0 & 0 & 1353 & 863 & 966 & 132 & 7659 & 65 \\
\hline 2013 & 0 & 0 & -140 & 724 & 811 & 11 & 6426 & 54 \\
\hline 2014 & 0 & 0 & 1260 & 724 & 811 & 111 & 6426 & 54 \\
\hline 2015 & 0 & 0 & & 0 & 0 & 0 & 0 & 0 \\
\hline 2016 & 0 & 0 & & 0 & 0 & 0 & 0 & 0 \\
\hline 2017 & 0 & 0 & 0 & 0 & 0 & 0 & 0 & 0 \\
\hline 2018 & 0 & 0 & 0 & 0 & 0 & 0 & 0 & 0 \\
\hline 2019 & 0 & 0 & 0 & 0 & 0 & 0 & 0 & 0 \\
\hline 2020 & 0 & 0 & 0 & 0 & 0 & 0 & 0 & 0 \\
\hline
\end{tabular}

NOTE: Positive number denotes incoming shipment, negative number denotes outgoing shipment. 
TABLE C.13. Annual Waste Form Processing Requirements at MRS/IS Handling Facility - Early Disposal Scenario (Packages)

\begin{tabular}{|c|c|c|c|c|c|c|}
\hline Year & $\begin{array}{c}\text { HLW } \\
\text { Canisters } \\
\end{array}$ & $\begin{array}{c}\text { RH-TRU } \\
\text { Canisters } \\
\end{array}$ & $\frac{D}{<5 R / h r}$ & $\frac{\mathrm{nS}}{>5 \mathrm{R} / \mathrm{hr}}$ & $\begin{array}{l}\text { CH-TRU } \\
\text { Drums }\end{array}$ & $\begin{array}{l}\mathrm{CH} \text {-TRU } \\
\text { Boxes } \\
\end{array}$ \\
\hline 1990 & 233 & 183 & 205 & 28 & 1623 & 13 \\
\hline 1991 & 467 & 368 & 410 & 55 & 3245 & 27 \\
\hline 1992 & 700 & 549 & 614 & 84 & 4868 & 41 \\
\hline 1993 & 0 & 0 & 0 & 0 & 0 & 0 \\
\hline 1994 & 0 & 0 & 0 & 0 & 0 & 0 \\
\hline 1995 & 0 & 0 & 0 & 0 & 0 & 0 \\
\hline 1996 & 0 & 0 & 0 & 0 & 0 & 0 \\
\hline 1997 & 0 & 0 & 0 & 0 & 0 & $D$ \\
\hline 1998 & 0 & 0 & 0 & 0 & 0 & 0 \\
\hline 1999 & 0 & 0 & 0 & 0 & 0 & 0 \\
\hline 2000 & 0 & 0 & 0 & 0 & 0 & 0 \\
\hline 2001 & 0 & 0 & 0 & 0 & 0 & 0 \\
\hline 2002 & 0 & 0 & 0 & 0 & 0 & 0 \\
\hline 2003 & 0 & 0 & 0 & 0 & 0 & 0 \\
\hline 2004 & 0 & 0 & 0 & 0 & 0 & 0 \\
\hline 2005 & 0 & 0 & 0 & 0 & 0 & 0 \\
\hline 2006 & 0 & 0 & 0 & 0 & 0 & 0 \\
\hline 2007 & 0 & 0 & 0 & 0 & 0 & 0 \\
\hline 2008 & 0 & 0 & 0 & 0 & 0 & 0 \\
\hline 2009 & 0 & 0 & 0 & 0 & 0 & 0 \\
\hline 2010 & 0 & 0 & 0 & 0 & 0 & 0 \\
\hline 2011 & 0 & 0 & 0 & 0 & 0 & 0 \\
\hline 2012 & 0 & 0 & 0 & 0 & 0 & 0 \\
\hline 2013 & 0 & 0 & 0 & 0 & 0 & 0 \\
\hline 2014 & 0 & 0 & 0 & 0 & 0 & 0 \\
\hline 2015 & 0 & 0 & 0 & 0 & 0 & 0 \\
\hline 2016 & 0 & 0 & 0 & 0 & 0 & 0 \\
\hline 2017 & 0 & 0 & 0 & 0 & 0 & 0 \\
\hline 2018 & 0 & 0 & 0 & 0 & 0 & 0 \\
\hline 2019 & 0 & 0 & 0 & 0 & 0 & 0 \\
\hline 2020 & 0 & 0 & 0 & 0 & 0 & 0 \\
\hline
\end{tabular}

NOTE: Positive number denotes incoming shipment, negative number denotes outgoing shipment. 
TABLE C.14. Annual Waste Form Processing Requirements at MRS/IS Handling Facility-Delayed Disposal, No Reprocessing Scenario (Packages)

\begin{tabular}{|c|c|c|c|c|c|c|c|c|}
\hline Year & \multicolumn{2}{|c|}{$\begin{array}{l}\text { Spent Fuel } \\
\text { Assemblies }\end{array}$} & $\begin{array}{c}H L W \\
\text { Canisters } \\
\end{array}$ & $\begin{array}{c}\mathrm{RH}-\mathrm{TRU} \\
\text { Canisters } \\
\end{array}$ & \multicolumn{2}{|c|}{ Drums } & $\begin{array}{l}\text { CH-TRU } \\
\text { Drums } \\
\end{array}$ & $\begin{array}{l}\mathrm{CH}-\mathrm{TRU} \\
\text { Boxes } \\
\end{array}$ \\
\hline 1990 & 934 & 698 & 0 & 0 & 0 & 0 & 0 & 0 \\
\hline 1991 & 1839 & 460 & 0 & 0 & 0 & 0 & 0 & 0 \\
\hline 1992 & 1378 & 948 & 0 & 0 & 0 & 0 & 0 & 0 \\
\hline 1993 & 1300 & 1013 & 0 & 0 & 0 & 0 & 0 & 0 \\
\hline 1994 & 2156 & 1457 & 0 & 0 & 0 & 0 & 0 & 0 \\
\hline 1995 & 1961 & 2138 & 0 & 0 & 0 & 0 & 0 & 0 \\
\hline 1996 & 2878 & 2336 & 0 & 0 & 0 & 0 & 0 & 0 \\
\hline 1997 & 3322 & 2143 & 0 & 0 & 0 & 0 & 0 & 0 \\
\hline 1998 & 2934 & 2855 & 0 & 0 & 0 & 0 & 0 & 0 \\
\hline 1999 & 4217 & 2346 & 0 & 0 & 0 & 0 & 0 & 0 \\
\hline 2000 & 4745 & 2936 & 0 & 0 & 0 & 0 & 0 & 0 \\
\hline 2001 & 4567 & 3647 & 0 & 0 & 0 & 0 & 0 & 0 \\
\hline 2002 & 5484 & 4184 & 0 & 0 & 0 & 0 & 0 & 0 \\
\hline 2003 & 6373 & 3605 & 0 & 0 & 0 & 0 & 0 & 0 \\
\hline 2004 & 6611 & 4414 & 0 & 0 & 0 & 0 & 0 & 0 \\
\hline 2005 & 6611 & 4072 & 0 & 0 & 0 & 0 & 0 & 0 \\
\hline 2006 & 6967 & 3996 & 0 & 0 & 0 & 0 & 0 & 0 \\
\hline 2007 & 6834 & 4810 & 0 & 0 & 0 & 0 & 0 & 0 \\
\hline 2008 & 1800 & 1333 & 0 & 0 & 0 & 0 & 0 & 0 \\
\hline 2009 & 4189 & 1468 & 0 & 0 & 0 & 0 & 0 & 0 \\
\hline 2010 & 1939 & 1587 & 0 & 0 & 0 & 0 & 0 & 0 \\
\hline 2011 & 1834 & 1010 & 0 & 0 & 0 & 0 & 0 & 0 \\
\hline 2012 & 0 & 0 & 0 & 0 & 0 & 0 & 0 & 0 \\
\hline 2013 & 0 & 0 & 0 & 0 & 0 & 0 & 0 & 0 \\
\hline 2014 & 0 & 0 & 0 & 0 & 0 & 0 & 0 & 0 \\
\hline 2015 & 0 & 0 & 0 & 0 & 0 & 0 & 0 & 0 \\
\hline 2016 & 0 & 0 & 0 & 0 & 0 & 0 & 0 & 0 \\
\hline 2017 & 0 & 0 & 0 & 0 & 0 & 0 & 0 & 0 \\
\hline 2018 & 0 & 0 & 0 & 0 & 0 & 0 & 0 & 0 \\
\hline 2019 & 0 & 0 & 0 & 0 & 0 & 0 & 0 & 0 \\
\hline 2020 & 0 & 0 & 0 & 0 & 0 & 0 & 0 & 0 \\
\hline
\end{tabular}

NOTE: Positive number denotes incoming shipment, negative number denotes outgoing shipment. 
TABLE C.15. Cumulative Waste Form Storage Requirements at MRS/IS

Facility - Reference Scenario (Packages)

\begin{tabular}{|c|c|c|c|c|c|c|c|}
\hline Year & $\begin{array}{l}\text { Spen } \\
\text { Asse } \\
\text { BWR }\end{array}$ & $\begin{array}{l}\text { Fuel } \\
\text { lies } \\
\text { PWR }\end{array}$ & $\begin{array}{c}\text { HLW } \\
\text { Canisters } \\
\end{array}$ & $\begin{array}{c}\mathrm{RH}-\mathrm{TRU} \\
\text { Canisters } \\
\end{array}$ & $\begin{array}{l}\text { RH-TRU } \\
\text { Drums } \\
\end{array}$ & $\begin{array}{l}\text { CH-TRU } \\
\text { Drums } \\
\end{array}$ & $\begin{array}{l}\mathrm{CH} \text {-TRU } \\
\text { Boxes } \\
\end{array}$ \\
\hline 1990 & 0 & 31 & 233 & 183 & 233 & 1623 & 13 \\
\hline 1991 & 0 & 0 & 700 & 551 & 698 & 4868 & 40 \\
\hline 1992 & 0 & 0 & 1400 & 1100 & 1396 & 9736 & 81 \\
\hline 1993 & 0 & 0 & 2100 & 1649 & 2094 & 74604 & 122 \\
\hline 1993 & 0 & 0 & 2800 & 2198 & 2792 & 19472 & 163 \\
\hline 1995 & 0 & 0 & 3500 & 2747 & 3490 & 2.4340 & 204 \\
\hline 1996 & 0 & 0 & 4200 & 3296 & 4188 & 20208 & 245 \\
\hline 1997 & 0 & 0 & 2900 & 3845 & 4886 & 34076 & 286 \\
\hline 1998 & 0 & 0 & 4760 & 3637 & 4621 & 28526 & 270 \\
\hline 1999 & 0 & 0 & 4620 & 3429 & 4356 & 28300 & 254 \\
\hline 2000 & 0 & 0 & 4480 & 3221 & 4091 & 28526 & 238 \\
\hline 2001 & 0 & 0 & 4573 & 3196 & 4058 & 2.8300 & 236 \\
\hline 2002 & 0 & 0 & 4060 & 2596 & 3295 & 22928 & 192 \\
\hline 2003 & 0 & 0 & 3220 & 1673 & 2122 & 14750 & 124 \\
\hline 2004 & 0 & 0 & 2380 & 750 & 949 & 6572 & 55 \\
\hline 2005 & 0 & 0 & 1540 & 0 & 0 & 0 & 0 \\
\hline 2006 & 0 & 0 & 1167 & 0 & 0 & 0 & 0 \\
\hline 2007 & 0 & 0 & 700 & 0 & 0 & 0 & 0 \\
\hline 2008 & 0 & 0 & 700 & 0 & 0 & 0 & 0 \\
\hline 2009 & 0 & 0 & 700 & 0 & 0 & 0 & 0 \\
\hline 2010 & 0 & 0 & 700 & 0 & 0 & 0 & 0 \\
\hline 2011 & 0 & 0 & 1167 & 37 & 47 & 325 & 3 \\
\hline 2012 & 0 & 0 & 1400 & 0 & 0 & 0 & 0 \\
\hline 2013 & 0 & 0 & 1260 & 220 & 246 & 1947 & 16 \\
\hline 2014 & 0 & 0 & 1960 & 440 & 492 & 3894 & 32 \\
\hline 2015 & 0 & 0 & 0 & 0 & 0 & 0 & 0 \\
\hline 2016 & 0 & 0 & 0 & 0 & 0 & 0 & 0 \\
\hline 2017 & 0 & 0 & 0 & 0 & 0 & 0 & 0 \\
\hline 2018 & 0 & 0 & 0 & 0 & 0 & 0 & 0 \\
\hline 2019 & 0 & 0 & 0 & 0 & 0 & 0 & 0 \\
\hline 2020 & 0 & 0 & 0 & 0 & 0 & 0 & 0 \\
\hline
\end{tabular}


TABLE C.16. Cumulative Waste Form Storage Requirements at MRS/IS Facility - Delayed Reprocessing Scenario (Packages)

\begin{tabular}{|c|c|c|c|c|c|c|c|c|}
\hline Year & \multicolumn{2}{|c|}{$\begin{array}{l}\text { Spent Fuel } \\
\text { Assemblies }\end{array}$} & $\begin{array}{c}\text { HLW } \\
\text { Canisters } \\
\end{array}$ & \multirow{2}{*}{$\begin{array}{c}\mathrm{RH}-\mathrm{TRU} \\
\text { Canisters } \\
\end{array}$} & \multicolumn{2}{|c|}{ Drums } & $\begin{array}{l}\text { CH-TRU } \\
\text { Drums } \\
\end{array}$ & $\begin{array}{l}\text { CH-TRU } \\
\text { Boxes } \\
\end{array}$ \\
\hline & & & & & & & & \\
\hline 1990 & 933 & 698 & 0 & 0 & 0 & 0 & 0 & 0 \\
\hline 1991 & 2772 & 1157 & 0 & 0 & 0 & 0 & 0 & 0 \\
\hline 1992 & 4150 & 2104 & 0 & 0 & 0 & 0 & 0 & 0 \\
\hline 1993 & 5450 & 3140 & 0 & 0 & 0 & 0 & 0 & 0 \\
\hline 1994 & 7605 & 4598 & 0 & 0 & 0 & 0 & 0 & 0 \\
\hline 1995 & 9566 & 6736 & 0 & 0 & 0 & 0 & 0 & 0 \\
\hline 1996 & 12444 & 9071 & 0 & 0 & 0 & 0 & 0 & 0 \\
\hline 1997 & 15766 & 11214 & 0 & 0 & 0 & 0 & 0 & 0 \\
\hline 1998 & 15766 & 11214 & 0 & 0 & 0 & 0 & 0 & 0 \\
\hline 1999 & 15766 & 11214 & 0 & 0 & 0 & 0 & 0 & 0 \\
\hline 2000 & 15766 & 11214 & 0 & 0 & 0 & 0 & 0 & 0 \\
\hline 2001 & 15766 & 11214 & & 0 & 0 & 0 & 0 & 0 \\
\hline 2002 & 15766 & 11214 & 0 & 0 & 0 & 0 & 0 & 0 \\
\hline 2003 & 15766 & 11214 & 0 & 0 & 0 & 0 & 0 & 0 \\
\hline 2004 & 15766 & 11214 & 0 & 0 & 0 & 0 & 0 & 0 \\
\hline 2005 & 15766 & 11214 & 0 & 0 & 0 & 0 & 0 & 0 \\
\hline 2006 & 15766 & 11214 & 0 & 0 & 0 & 0 & 0 & 0 \\
\hline 2007 & 15766 & 11214 & 0 & 0 & 0 & 0 & 0 & 0 \\
\hline 2008 & 15766 & 11214 & 0 & 0 & 0 & 0 & 0 & 0 \\
\hline 2009 & 15766 & 11214 & 0 & 0 & 0 & 0 & 0 & 0 \\
\hline 2010 & 15766 & 11214 & 0 & 0 & 0 & 0 & 0 & 0 \\
\hline 2011 & 15766 & 11214 & 0 & 0 & 0 & 0 & 0 & 0 \\
\hline 2012 & 14744 & 10162 & 0 & 0 & 0 & 0 & 0 & 0 \\
\hline 2013 & 14310 & 9167 & 0 & 0 & 0 & 0 & 0 & 0 \\
\hline 2014 & 12571 & 7825 & 0 & 0 & 0 & 0 & 0 & 0 \\
\hline 2015 & 7849 & 5199 & 0 & 0 & 0 & 0 & 0 & 0 \\
\hline 2016 & 3399 & 959 & 0 & 0 & 0 & 0 & 0 & 0 \\
\hline 2017 & 0 & 0 & 0 & 0 & 0 & 0 & 0 & 0 \\
\hline
\end{tabular}


TABLE C.17. Cumulative Waste Form Storage Requirements at MRS/IS Facility - Delayed Disposal Scenario (Packages)

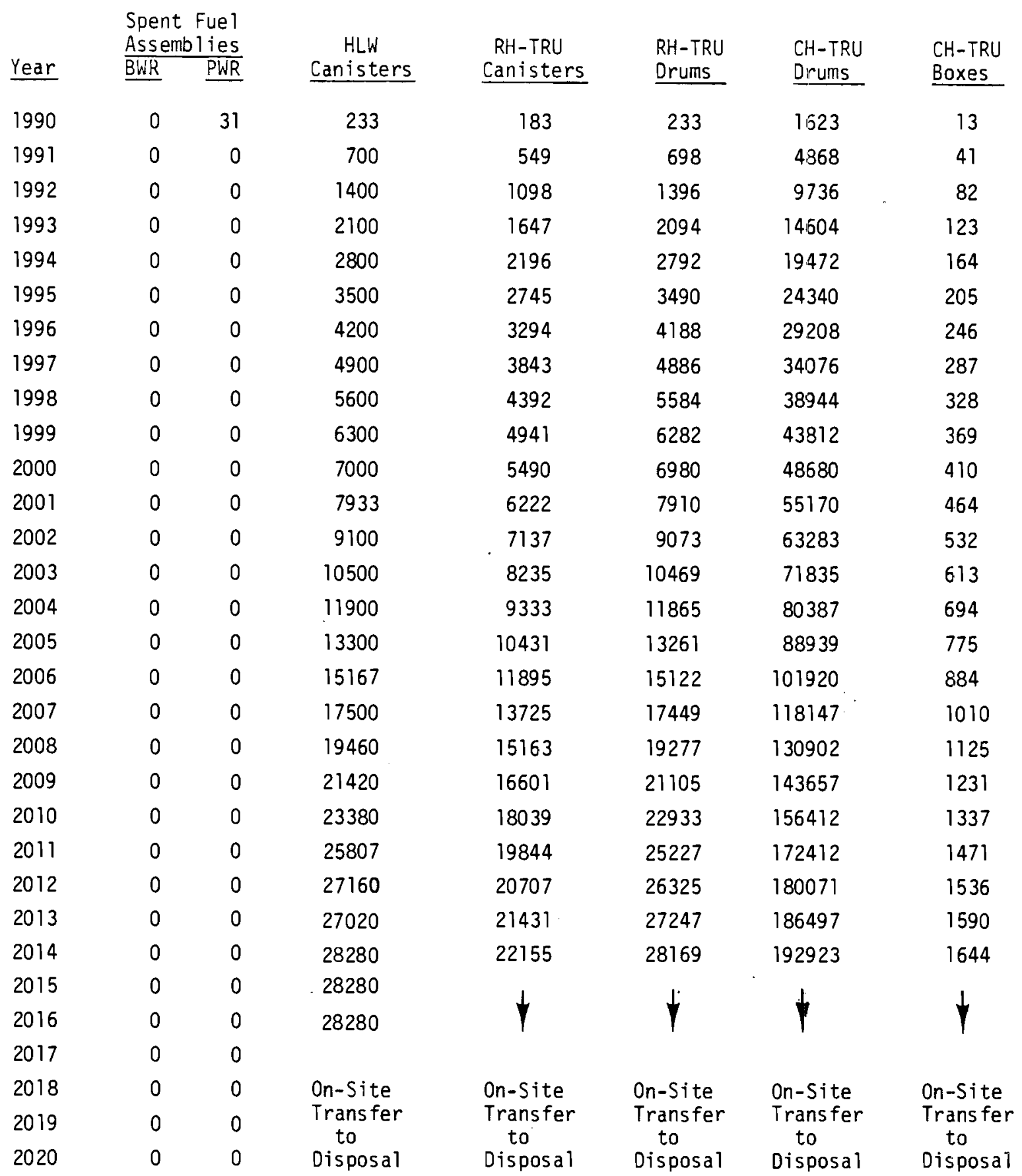


TABLE C.18. Cumulative Waste Form Storage Requirements at MRS/IS Facility - Early Disposal Scenario (Packages)

\begin{tabular}{|c|c|c|c|c|c|c|}
\hline Year & $\begin{array}{l}\text { Spent Fue } 1 \\
\text { Assemblies } \\
\underline{\text { BWR } \quad \text { PWR }}\end{array}$ & $\begin{array}{c}\mathrm{HLW} \\
\text { Canisters } \\
\end{array}$ & $\begin{array}{c}\text { RH-TRU } \\
\text { Canisters } \\
\end{array}$ & $\begin{array}{l}\text { RH-TRU } \\
\text { Drums } \\
\end{array}$ & $\begin{array}{l}\mathrm{CH}-\mathrm{TRU} \\
\text { Drums } \\
\end{array}$ & $\begin{array}{l}\mathrm{CH}-\mathrm{TRU} \\
\text { Boxes } \\
\end{array}$ \\
\hline 1990 & 0 & 233 & 183 & 233 & 1623 & 13 \\
\hline 1991 & 0 & 700 & 551 & 698 & 4868 & 30 \\
\hline 1992 & 0 & 1400 & 1100 & 1396 & 9736 & 81 \\
\hline 1993 & 0 & 0 & 0 & 0 & 0 & 0 \\
\hline 1994 & 0 & 0 & 0 & 0 & 0 & 0 \\
\hline 1995 & 0 & 0 & 0 & 0 & 0 & 0 \\
\hline 1996 & 0 & 0 & 0 & 0 & 0 & 0 \\
\hline 1997 & 0 & 0 & 0 & 0 & 0 & 0 \\
\hline 1998 & 0 & 0 & 0 & 0 & 0 & 0 \\
\hline 1999 & 0 & 0 & 0 & 0 & 0 & 0 \\
\hline 2000 & 0 & 0 & 0 & 0 & 0 & 0 \\
\hline 2001 & 0 & 0 & 0 & 0 & 0 & 0 \\
\hline 2002 & 0 & 0 & 0 & 0 & 0 & 0 \\
\hline 2003 & 0 & 0 & 0 & 0 & 0 & 0 \\
\hline 2004 & 0 & 0 & 0 & 0 & 0 & 0 \\
\hline 2005 & 0 & 0 & 0 & 0 & 0 & 0 \\
\hline 2006 & 0 & 0 & 0 & 0 & 0 & 0 \\
\hline 2007 & 0 & 0 & 0 & 0 & 0 & 0 \\
\hline 2008 & 0 & 0 & 0 & 0 & 0 & 0 \\
\hline 2009 & 0 & 0 & 0 & 0 & 0 & 0 \\
\hline 2010 & 0 & 0 & 0 & 0 & 0 & 0 \\
\hline וו120 & 0 & 0 & 0 & 0 & 0 & 0 \\
\hline 2012 & 0 & 0 & 0 & 0 & 0 & 0 \\
\hline 2013 & 0 & 0 & 0 & 0 & 0 & 0 \\
\hline 2014 & 0 & 0 & 0 & 0 & 0 & 0 \\
\hline 2015 & 0 & 0 & 0 & 0 & 0 & 0 \\
\hline 2016 & 0 & 0 & 0 & 0 & 0 & 0 \\
\hline 2017 & 0 & 0 & 0 & 0 & 0 & 0 \\
\hline 2018 & 0 & 0 & 0 & 0 & 0 & 0 \\
\hline 2019 & 0 & 0 & 0 & 0 & 0 & 0 \\
\hline 2020 & 0 & 0 & 0 & 0 & 0 & 0 \\
\hline
\end{tabular}


TABLE C.19. Cumulative Waste Form Storage Requirements at MRS/IS

Facility - Delayed Disposal, No Reprocessing Scenario (Packages)

\begin{tabular}{|c|c|c|c|c|c|c|c|}
\hline Year & $\begin{array}{l}\text { Spen } \\
\text { Asse } \\
\text { BWR }\end{array}$ & $\begin{array}{l}\text { Fe 1 } \\
\text { ies } \\
\text { PWR }\end{array}$ & $\begin{array}{c}H L W \\
\text { Canisters }\end{array}$ & $\begin{array}{c}\text { RH-TRU } \\
\text { Canisters }\end{array}$ & $\begin{array}{l}\text { RH-TRU } \\
\text { Drums }\end{array}$ & $\begin{array}{l}\mathrm{CH}-\mathrm{TRU} \\
\text { Drums }\end{array}$ & $\begin{array}{l}\text { CH-TRU } \\
\text { Boxes }\end{array}$ \\
\hline 1990 & 0 & 31 & 233 & 183 & 233 & 1623 & 13 \\
\hline 1991 & 0 & 0 & 700 & 551 & 698 & 4868 & 40 \\
\hline 1992 & 0 & 0 & 1400 & 1100 & 1396 & 9736 & 81 \\
\hline 1993 & 0 & 0 & 0 & 0 & 0 & 0 & 0 \\
\hline 1994 & 0 & 0 & 0 & 0 & 0 & 0 & 0 \\
\hline 1995 & 0 & 0 & 0 & 0 & 0 & 0 & 0 \\
\hline 1996 & 0 & 0 & 0 & 0 & 0 & 0 & 0 \\
\hline 1997 & 0 & 0 & 0 & 0 & 0 & 0 & 0 \\
\hline 1998 & 0 & 0 & 0 & 0 & 0 & 0 & 0 \\
\hline 1999 & 0 & 0 & 0 & 0 & 0 & 0 & 0 \\
\hline 2000 & 0 & 0 & 0 & 0 & 0 & 0 & 0 \\
\hline 2001 & 0 & 0 & 0 & 0 & 0 & 0 & 0 \\
\hline 2002 & 0 & 0 & 0 & 0 & 0 & 0 & 0 \\
\hline 2003 & 0 & 0 & 0 & 0 & 0 & 0 & 0 \\
\hline 2004 & 0 & 0 & 0 & 0 & 0 & 0 & 0 \\
\hline 2005 & 0 & 0 & 0 & 0 & 0 & 0 & 0 \\
\hline 2006 & 0 & 0 & 0 & 0 & 0 & 0 & 0 \\
\hline 2007 & 0 & 0 & 0 & 0 & 0 & 0 & 0 \\
\hline 2008 & 0 & 0 & 0 & 0 & 0 & 0 & 0 \\
\hline 2009 & 0 & 0 & 0 & 0 & 0 & 0 & 0 \\
\hline 2010 & 0 & 0 & 0 & 0 & 0 & 0 & 0 \\
\hline 2011 & 0 & 0 & 0 & 0 & 0 & 0 & 0 \\
\hline 2012 & 0 & 0 & 0 & 0 & 0 & 0 & 0 \\
\hline 2013 & 0 & 0 & 0 & 0 & 0 & 0 & 0 \\
\hline 2014 & 0 & 0 & 0 & 0 & 0 & 0 & 0 \\
\hline 2015 & 0 & 0 & 0 & 0 & 0 & 0 & 0 \\
\hline 2016 & 0 & 0 & 0 & 0 & 0 & 0 & 0 \\
\hline 2017 & 0 & 0 & 0 & 0 & 0 & 0 & 0 \\
\hline 2018 & 0 & 0 & 0 & 0 & 0 & 0 . & 0 \\
\hline 2019 & 0 & 0 & 0 & 0 & 0 & 0 & 0 \\
\hline 2020 & 0 & 0 & 0 & 0 & 0 & 0 & 0 \\
\hline
\end{tabular}


TABLE C.20. Number of Offsite Shipments Handled Annually at MRS/IS Facility - Reference Scenario

1990
1991
1992
1993
1994
1995
1996
1997
1998
1999
2000
2001
2002
2003
2004
2005
2006
2007
2008
2009
2010
2011
2012
2013
2014
2015
2016
2017
2018
2019
2020
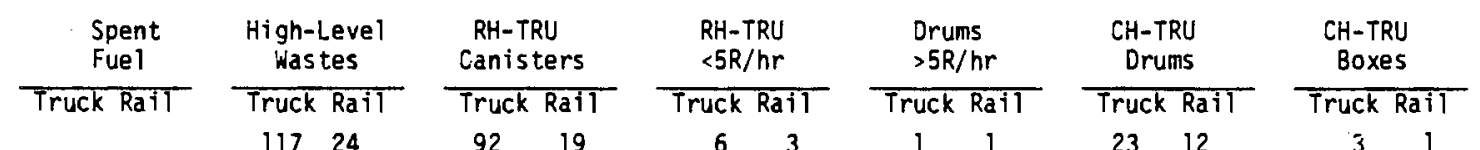

1991

$\begin{array}{ll}117 & 24 \\ 234 & 47\end{array}$

$\begin{array}{rr}92 & 19 \\ 184 & 37 \\ 275 & 55\end{array}$

$\begin{array}{rr}6 & 3 \\ 15 & 5\end{array}$

$\begin{array}{ll}350 & 70\end{array}$

$275 \quad 55$

35070

$275 \quad 55$

$350 \quad 70$

$275 \quad 55$

$350 \quad 70$

$275 \quad 55$.

$350 \quad 70$

275

00

00

00

$47 \quad 10$

00

00

00

$\begin{array}{ll}0 & 0 \\ 0 & 0\end{array}$

00

00

00

$\begin{array}{ll}15 & 5 \\ 20 & 8\end{array}$

208

208

208

$20 \quad 8$

208 (1)

o

0

0

00

00

0

$0 \quad 0$

00

$$
00
$$

$$
00
$$

$\begin{array}{ll}0 & 0 \\ 0 & 0\end{array}$

$\begin{array}{ll}0 & 0 \\ 0 & 0\end{array}$

00

$\begin{array}{ll}0 & 0 \\ 0 & 0\end{array}$

$234 \quad 47$

$117 \quad 24$

$210 \quad 42$

$350 \quad 70$

00

00

0

00

00

00

00

00

$\begin{array}{ll}0 & 0 \\ 0 & 0\end{array}$

$\begin{array}{ll}2 & 2 \\ 6 & 2\end{array}$

62

62

62

62

62

$\begin{array}{ll}0 & 0 \\ 0 & 0\end{array}$

00

00

00

00

00

00

00

00

00

$\begin{array}{ll}0 & 0 \\ 0 & 0\end{array}$ 0

$$
\begin{array}{ll}
0 & 0 \\
0 & 0
\end{array}
$$$$
\begin{array}{ll}
0 & 0 \\
0 & 0
\end{array}
$$

$$
\begin{array}{ll}
0 & 0 \\
0 & 0
\end{array}
$$$$
00
$$$$
\begin{array}{ll}
0 & 0 \\
0 & 0
\end{array}
$$$$
\begin{array}{rr}
0 & 0 \\
19 & 4
\end{array}
$$$$
00
$$$$
00
$$$$
00
$$$$
\begin{array}{rr}
0 & 0 \\
110 & 22
\end{array}
$$

93

$110 \quad 22$

$\begin{array}{ll}9 & 3 \\ 0 & 0\end{array}$

$\begin{array}{ll}0 & 0 \\ 0 & 0 \\ 0 & 0 \\ 0 & 0 \\ 0 & 0\end{array}$

0

$\begin{array}{ll}23 & 12 \\ 45 & 23 \\ 68 & 34 \\ 68 & 34 \\ 68 & 34 \\ 68 & 34 \\ 68 & 34 \\ 68 & 34\end{array}$

31

52

74

74

74

74

74

74

$\begin{array}{llll}0 & 0 & 0 & 0\end{array}$

$\begin{array}{llll}0 & 0 & 0 & 0\end{array}$

$\begin{array}{llll}0 & 0 & 0 & 0\end{array}$

$\begin{array}{llll}0 & 0 & 0 & 0\end{array}$

$\begin{array}{llll}0 & 0 & 0 & 0\end{array}$

$\begin{array}{llll}0 & 0 & 0 & 0\end{array}$

$\begin{array}{llll}0 & 0 & 0 & 0\end{array}$

$\begin{array}{llll}0 & 0 & 0 & 0\end{array}$

$\begin{array}{llll}0 & 0 & 0 & 0\end{array}$

$\begin{array}{llll}0 & 0 & 0 & 0\end{array}$

$\begin{array}{llll}0 & 0 & 0 & 0\end{array}$

$\begin{array}{llll}0 & 0 & 0 & 0\end{array}$

$\begin{array}{lll}0 & 0 & 0\end{array}$

$\begin{array}{llll}6 & 3 & 1 & 0\end{array}$

$\begin{array}{llll}6 & 3 & 0\end{array}$

$\begin{array}{llll}27 & 14 & 3 & 2\end{array}$

$\begin{array}{llll}27 & 14 & 3 & 2\end{array}$

Note: Positive number denotes incoming shipment, negative number denotes outgoing shipment. 
TABLE C.21. Number of Offsite Shipments Handled Annually at MRS/IS Facility - Delayed Reprocessing Scenario

\begin{tabular}{|c|c|c|c|c|c|c|c|c|c|c|c|c|c|}
\hline \multirow{2}{*}{\multicolumn{2}{|c|}{$\begin{array}{c}\begin{array}{c}\text { Spent } \\
\text { Fuel }\end{array} \\
\text { Truck Rail }\end{array}$}} & \multicolumn{2}{|c|}{$\begin{array}{l}\text { High-Leve } 1 \\
\text { Wastes }\end{array}$} & \multicolumn{2}{|c|}{$\begin{array}{l}\text { RH-TRU } \\
\text { Canisters }\end{array}$} & \multicolumn{2}{|c|}{$\begin{array}{l}\text { RH-TRU } \\
<5 R / h r\end{array}$} & \multicolumn{2}{|c|}{$\begin{array}{l}\text { Drums } \\
>5 \mathrm{R} / \mathrm{hr}\end{array}$} & \multicolumn{2}{|c|}{$\begin{array}{c}\text { CH-TRU } \\
\text { Drums }\end{array}$} & \multicolumn{2}{|c|}{$\begin{array}{c}\text { CH-TRU } \\
\text { Boxes }\end{array}$} \\
\hline & & Truc & बiा & Truc & रail & $\overline{\text { Truc }}$ & Raji & Trucl & Rail & Truck & 2ai1 & Truck & Ra i \\
\hline 583 & 76 & 0 & 0 & 0 & 0 & 0 & 0 & 0 & 0 & 0 & 0 & 0 & 0 \\
\hline 690 & 84 & 0 & 0 & 0 & 0 & 0 & 0 & 0 & 0 & 0 & 0 & 0 & 0 \\
\hline 819 & 107 & 0 & 0 & 0 & 0 & 0 & 0 & 0 & 0 & 0 & 0 & 0 & 0 \\
\hline 832 & 110 & 0 & 0 & 0 & 0 & 0 & 0 & 0 & 0 & 0 & 0 & 0 & 0 \\
\hline 1268 & 165 & 0 & 0 & 0 & 0 & 0 & 0 & 0 & 0 & 0 & 0 & 0 & 0 \\
\hline 1560 & 208 & 0 & 0 & 0 & 0 & 0 & 0 & 0 & 0 & 0 & 0 & 0 & 0 \\
\hline 1888 & 247 & 0 & 0 & 0 & 0 & 0 & 0 & 0 & 0 & 0 & 0 & 0 & 0 \\
\hline \multirow[t]{2}{*}{1903} & 246 & 0 & 0 & 0 & 0 & 0 & 0 & 0 & 0 & 0 & 0 & 0 & 0 \\
\hline & & 0 & 0 & 0 & 0 & 0 & 0 & 0 & 0 & 0 & 0 & 0 & 0 \\
\hline 0 & 0 & 0 & 0 & 0 & 0 & 0 & 0 & 0 & 0 & 0 & 0 & 0 & 0 \\
\hline 0 & 0 & 0 & 0 & 0 & 0 & 0 & 0 & 0 & 0 & 0 & 0 & 0 & 0 \\
\hline 0 & 0 & & & 0 & 0 & 0 & 0 & 0 & 0 & 0 & 0 & 0 & 0 \\
\hline 0 & 0 & 0 & 0 & 0 & 0 & 0 & 0 & 0 & 0 & 0 & 0 & 0 & 0 \\
\hline 0 & 0 & 0 & 0 & 0 & 0 & 0 & 0 & 0 & 0 & 0 & 0 & 0 & 0 \\
\hline 0 & 0 & 0 & 0 & 0 & 0 & 0 & 0 & 0 & 0 & 0 & 0 & 0 & 0 \\
\hline 0 & 0 & 0 & 0 & 0 & 0 & 0 & 0 & 0 & 0 & 0 & 0 & 0 & 0 \\
\hline 0 & 0 & 0 & 0 & 0 & 0 & 0 & 0 & 0 & 0 & 0 & 0 & 0 & 0 \\
\hline 0 & 0 & 0 & 0 & 0 & 0 & 0 & 0 & 0 & 0 & 0 & 0 & 0 & 0 \\
\hline 0 & 0 & 0 & 0 & 0 & 0 & 0 & 0 & 0 & 0 & 0 & 0 & 0 & 0 \\
\hline 0 & 0 & 0 & 0 & 0 & 0 & 0 & 0 & 0 & 0 & 0 & 0 & 0 & 0 \\
\hline 0 & 0 & 0 & 0 & 0 & 0 & 0 & 0 & 0 & 0 & 0 & 0 & 0 & 0 \\
\hline 0 & 0 & 0 & 0 & 0 & 0 & 0 & 0 & 0 & 0 & 0 & 0 & 0 & 0 \\
\hline-770 & -105 & 0 & 0 & 0 & 0 & 0 & 0 & 0 & 0 & 0 & 0 & 0 & 0 \\
\hline-598 & -84 & 0 & 0 & 0 & 0 & 0 & 0 & 0 & 0 & 0 & 0 & 0 & 0 \\
\hline-1100 & -145 & 0 & 0 & 0 & 0 & 0 & 0 & 0 & 0 & 0 & 0 & 0 & 0 \\
\hline-2258 & -295 & 0 & 0 & 0 & 0 & 0 & 0 & 0 & 0 & 0 & 0 & 0 & 0 \\
\hline-3453 & -452 & 0 & 0 & 0 & 0 & 0 & 0 & 0 & 0 & 0 & 0 & 0 & 0 \\
\hline-1320 & -164 & 0 & 0 & 0 & 0 & 0 & 0 & 0 & 0 & 0 & 0 & 0 & 0 \\
\hline 0 & 0 & 0 & 0 & 0 & 0 & 0 & 0 & 0 & 0 & 0 & 0 & 0 & 0 \\
\hline 0 & 0 & 0 & 0 & 0 & 0 & 0 & 0 & 0 & 0 & 0 & 0 & 0 & 0 \\
\hline 0 & 0 & 0 & 0 & 0 & 0 & 0 & 0 & 0 & 0 & 0 & 0 & 0 & 0 \\
\hline
\end{tabular}

Note: Positive number denotes incoming shipment, negative number denotes outgoing shipment. 
TABLE C.22. Number of Offsite Shipments Handled Annually at MRS/IS Facility - Delayed Disposal Scenario

\begin{tabular}{|c|c|c|c|c|c|c|c|c|c|c|c|c|c|c|}
\hline & & & $\begin{array}{l}\text { High- } \\
\text { Was }\end{array}$ & $\begin{array}{l}\text { evel } \\
\text { es }\end{array}$ & $\begin{array}{r}\mathrm{RH}-\mathrm{T} \\
\text { Canis }\end{array}$ & $\begin{array}{l}\text { RU } \\
\text { ters }\end{array}$ & $\begin{array}{l}\mathrm{RH}- \\
-5 \mathrm{R}\end{array}$ & & $\begin{array}{l}\text { Drun } \\
>5 R\end{array}$ & & $\begin{array}{c}\mathrm{CH}-\mathrm{TP} \\
\text { Drun }\end{array}$ & & $\begin{array}{r}\mathrm{CH}-\mathrm{T} \\
\text { Box }\end{array}$ & \\
\hline & Truck & रaiा & Truck & $\overline{\text { Rail }}$ & Truck & $\overline{\text { Rail }}$ & Truck & $\overline{\text { Rail }}$ & Truck & $\overline{\operatorname{Ra} i 1}$ & Truck & Rail & Truck & Rail \\
\hline 1990 & & & 117 & 24 & 92 & 19 & 6 & 3 & 1 & 1 & 23 & 12 & 3 & 1 \\
\hline 1991 & & & 234 & 47 & 184 & 37 & 15 & 4 & 2 & 2 & 45 & 23 & 5 & 2 \\
\hline 1992 & 0 & 0 & 350 & 70 & 275 & 55 & 20 & 8 & 6 & 2 & 68 & 34 & 7 & 4 \\
\hline 1993 & 0 & 0 & 350 & 70 & 275 & 55 & 20 & 8 & 6 & 2 & 68 & 34 & 7 & 4 \\
\hline 1994 & 0 & 0 & 350 & 70 & 275 & 55 & 20 & 8 & 6 & 2 & 68 & 34 & 7 & 4 \\
\hline 1995 & 0 & 0 & 350 & 70 & 275 & 55 & 20 & 8 & 6 & 2 & 68 & 34 & 7 & 4 \\
\hline 1996 & 0 & 0 & 350 & 70 & 275 & 55 & 20 & 8 & 6 & 2 & 68 & 34 & 7 & 4 \\
\hline 1997 & 0 & 0 & 350 & 70 & 275 & 55 & 20 & 8 & 6 & 2 & 68 & 34 & 7 & 4 \\
\hline 1998 & 0 & 0 & 350 & 70 & 275 & 55 & 20 & 8 & 6 & 2 & 68 & 34 & 7 & 4 \\
\hline 1999 & 0 & 0 & 350 & 70 & 275 & 55 & 20 & 8 & 6 & 2 & 68 & 34 & 7 & 4 \\
\hline 2000 & 0 & 0 & 350 & 70 & 275 & 55 & 20 & 8 & 6 & 2 & 68 & 34 & 7 & 4 \\
\hline 2001 & 0 & 0 & 463 & 94 & 362 & 74 & 29 & 10 & 7 & 3 & 91 & 45 & 8 & 5 \\
\hline 2002 & 0 & 0 & 582 & 117 & 460 & 91 & 35 & 13 & 8 & 4 & 112 & 57 & 11 & 6 \\
\hline 2003 & 0 & 0 & 700 & 150 & 658 & 110 & 43 & 15 & 12 & 4 & 118 & 60 & 13 & 7 \\
\hline 2004 & 0 & 0 & 700 & 140 & 548 & 110 & 43 & 15 & 12 & 4 & 118 & 60 & 13 & 7 \\
\hline 2005 & 0 & 0 & 700 & 140 & 548 & 110 & 43 & 15 & 12 & 4 & 118 & 60 & 13 & 7 \\
\hline 2006 & 0 & 0 & 932 & 187 & 729 & 147 & 57 & 20 & 14 & 6 & 179 & 91 & 17 & 10 \\
\hline 2007 & 0 & 0 & 1164 & 234 & 915 & 183 & 72 & 25 & 19 & 7 & 225 & 113 & 21 & 12 \\
\hline 2008 & 0 & 0 & 980 & 196 & 718 & 144 & 55 & 20 & 14 & 7 & 117 & 89 & 18 & 9 \\
\hline 2009 & 0 & 0 & 980 & 196 & 718 & 144 & 55 & 20 & 14 & 7 & 117 & 89 & 18 & 9 \\
\hline 2010 & 0 & 0 & 980 & 196 & 718 & 144 & 55 & 20 & 14 & 7 & 117 & 89 & 18 & 9 \\
\hline 2011 & 0 & 0 & 1212 & 243 & 900 & 181 & 70 & 25 & 19 & 7 & 223 & 111 & 21 & 12 \\
\hline 2012 & 0 & 0 & 674 & 136 & 433 & 86 & 33 & 12 & 10 & 3 & 105 & 54 & 10 & 6 \\
\hline 2013 & 0 & 0 & 376 & 76 & 364 & 72 & 28 & 10 & 7 & 3 & 89 & 45 & 8 & 5 \\
\hline 2014 & 0 & 0 & 630 & 126 & 364 & 72 & 28 & 10 & 7 & 3 & 89 & 45 & 8 & 5 \\
\hline 2015 & 0 & 0 & 83 & 17 & 0 & 0 & 0 & 0 & 0 & 0 & 0 & 0 & 0 & 0 \\
\hline 2016 & 0 & 0 & 122 & 26 & 0 & 0 & 0 & 0 & 0 & 0 & 0 & 0 & 0 & 0 \\
\hline 2017 & 0 & 0 & 0 & 0 & 0 & 0 & 0 & 0 & 0 & 0 & 0 & 0 & 0 & 0 \\
\hline 2018 & 0 & 0 & 0 & 0 & 0 & 0 & 0 & 0 & 0 & 0 & 0 & 0 & 0 & 0 \\
\hline 2019 & 0 & 0 & 0 & 0 & 0 & 0 & 0 & 0 & 0 & 0 & 0 & 0 & 0 & 0 \\
\hline 2020 & 0 & 0 & 0 & 0 & 0 & 0 & 0 & 0 & 0 & 0 & 0 & 0 & 0 & 0 \\
\hline
\end{tabular}

Note: Positive number denotes incoming shipment, negative number denotes outgoing shipment. 
TABLE C.23. Number of Offsite Shipments Handled Annually at MRS/IS Facility - Early Disposal Scenario

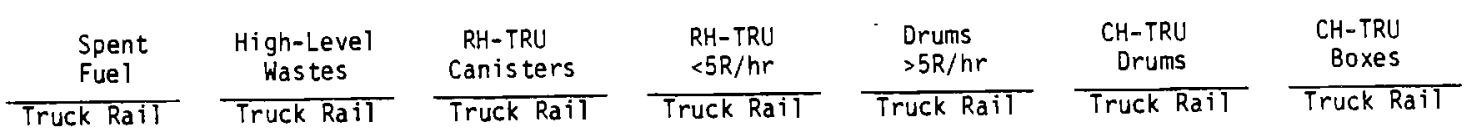

\begin{tabular}{|c|c|c|c|c|c|c|c|c|c|c|c|c|c|}
\hline 1990 & & & 117 & 24 & 92 & 19 & 6 & 3 & 1 & 1 & 23 & 12 & 3 \\
\hline 1991 & & & 234 & 47 & 184 & 37 & 15 & 5 & 2 & 2 & 45 & 23 & 5 \\
\hline 1992 & 0 & 0 & 350 & 70 & 275 & 55 & 20 & 8 & 6 & 2 & 68 & 34 & 7 \\
\hline 1993 & 0 & 0 & 0 & 0 & 0 & 0 & 0 & 0 & 0 & 0 & 0 & 0 & 0 \\
\hline 1994 & 0 & 0 & 0 & 0 & 0 & 0 & 0 & 0 & 0 & 0 & 0 & 0 & 0 \\
\hline 1995 & 0 & 0 & 0 & 0 & 0 & 0 & 0 & 0 & 0 & 0 & 0 & 0 & 0 \\
\hline 1996 & 0 & 0 & 0 & 0 & 0 & 0 & 0 & 0 & 0 & 0 & 0 & 0 & 0 \\
\hline 1997 & 0 & 0 & 0 & 0 & 0 & 0 & 0 & 0 & 0 & 0 & 0 & 0 & 0 \\
\hline 1998 & 0 & 0 & 0 & 0 & 0 & 0 & 0 & 0 & 0 & 0 & 0 & 0 & 0 \\
\hline 1999 & 0 & 0 & 0 & 0 & 0 & 0 & 0 & 0 & 0 & 0 & 0 & 0 & 0 \\
\hline 2000 & 0 & 0 & 0 & 0 & 0 & 0 & 0 & 0 & 0 & 0 & 0 & 0 & 0 \\
\hline 2001 & 0 & 0 & 0 & 0 & 0 & 0 & 0 & 0 & 0 & 0 & 0 & 0 & 0 \\
\hline 2002 & 0 & 0 & 0 & 0 & 0 & 0 & 0 & 0 & 0 & 0 & 0 & 0 & 0 \\
\hline 2003 & 0 & 0 & 0 & 0 & 0 & 0 & 0 & 0 & 0 & 0 & 0 & 0 & 0 \\
\hline 2004 & 0 & 0 & 0 & 0 & 0 & 0 & 0 & 0 & 0 & 0 & 0 & 0 & 0 \\
\hline 2005 & 0 & 0 & 0 & 0 & 0 & 0 & 0 & 0 & 0 & 0 & 0 & 0 & 0 \\
\hline 2006 & 0 & 0 & 0 & 0 & 0 & 0 & 0 & 0 & 0 & 0 & 0 & 0 & 0 \\
\hline 2007 & 0 & 0 & 0 & 0 & 0 & 0 & 0 & 0 & 0 & 0 & 0 & 0 & 0 \\
\hline 2008 & 0 & 0 & 0 & 0 & 0 & 0 & 0 & 0 & 0 & 0 & 0 & 0 & 0 \\
\hline 2009 & 0 & 0 & 0 & 0 & 0 & 0 & 0 & 0 & 0 & 0 & 0 & 0 & 0 \\
\hline 2010 & 0 & 0 & 0 & 0 & 0 & 0 & 0 & 0 & 0 & 0 & 0 & 0 & 0 \\
\hline 2011 & 0 & 0 & 0 & 0 & 0 & 0 & 0 & 0 & 0 & 0 & 0 & 0 & 0 \\
\hline 2012 & 0 & 0 & 0 & 0 & 0 & 0 & 0 & 0 & 0 & 0 & 0 & 0 & 0 \\
\hline 2013 & 0 & 0 & 0 & 0 & 0 & 0 & 0 & 0 & 0 & 0 & 0 & 0 & 0 \\
\hline 2014 & 0 & 0 & 0 & 0 & 0 & 0 & 0 & 0 & 0 & 0 & 0 & 0 & 0 \\
\hline 2015 & 0 & 0 & 0 & 0 & 0 & 0 & 0 & 0 & 0 & 0 & 0 & 0 & 0 \\
\hline 2016 & 0 & 0 & 0 & 0 & 0 & 0 & 0 & 0 & 0 & 0 & 0 & 0 & 0 \\
\hline 2017 & 0 & 0 & 0 & 0 & 0 & 0 & 0 & 0 & 0 & 0 & 0 & 0 & 0 \\
\hline 2018 & 0 & 0 & 0 & 0 & 0 & 0 & 0 & 0 & 0 & 0 & 0 & 0 & 0 \\
\hline 2019 & 0 & 0 & 0 & 0 & 0 & 0 & 0 & 0 & 0 & 0 & 0 & 0 & 0 \\
\hline 2020 & 0 & 0 & 0 & 0 & 0 & 0 & 0 & 0 & 0 & 0 & 0 & 0 & 0 \\
\hline
\end{tabular}

Note: Positive number denotes incoming shipment, negative number denotes outgoing shipment. 
TABLE C.24. Number of Off site Shipments Handled Annually at MRS/IS Facility - Delayed Disposal, No Reprocessing Scenario

\begin{tabular}{|c|c|c|c|c|c|c|}
\hline $\begin{array}{l}\text { Spent } \\
\text { Fuel }\end{array}$ & $\begin{array}{c}\text { High-Level } \\
\text { Wastes }\end{array}$ & $\begin{array}{c}\text { RH-TRU } \\
\text { Canisters }\end{array}$ & $\begin{array}{l}\text { RH-TRU } \\
<5 R / h r\end{array}$ & $\begin{array}{l}\text { Drums } \\
>5 \mathrm{R} / \mathrm{hr}\end{array}$ & $\begin{array}{c}\mathrm{CH}-\mathrm{TRU} \\
\text { Drums }\end{array}$ & $\begin{array}{c}\text { CH-TRU } \\
\text { Boxes }\end{array}$ \\
\hline Rail & Truck Ra & Truck Rail & Truck Rail & Truck Rail & Truck Rail & Truck Rail \\
\hline
\end{tabular}

\begin{tabular}{|c|c|c|c|c|c|c|c|c|c|c|c|c|c|c|}
\hline 1990 & 583 & 76 & 0 & 0 & 0 & 0 & 0 & 0 & 0 & 0 & 0 & 0 & 0 & 0 \\
\hline 1991 & 690 & 84 & 0 & 0 & 0 & 0 & 0 & 0 & 0 & 0 & 0 & 0 & 0 & 0 \\
\hline 1992 & 819 & 107 & 0 & 0 & 0 & 0 & 0 & 0 & 0 & 0 & 0 & 0 & 0 & 0 \\
\hline 1993 & 832 & 110 & 0 & 0 & 0 & 0 & 0 & 0 & 0 & 0 & 0 & 0 & 0 & 0 \\
\hline 1994 & 1268 & 165 & 0 & 0 & 0 & 0 & 0 & 0 & 0 & 0 & 0 & 0 & 0 & 0 \\
\hline 1995 & 1560 & 208 & 0 & 0 & 0 & 0 & 0 & 0 & 0 & 0 & 0 & 0 & 0 & 0 \\
\hline 1996 & 1888 & 247 & 0 & 0 & 0 & 0 & 0 & 0 & 0 & 0 & 0 & 0 & 0 & 0 \\
\hline 1997 & 1903 & 246 & 0 & 0 & 0 & 0 & 0 & 0 & 0 & 0 & 0 & 0 & 0 & 0 \\
\hline 1998 & 2156 & 286 & 0 & 0 & 0 & 0 & 0 & 0 & 0 & 0 & 0 & 0 & 0 & 0 \\
\hline 1999 & 2465 & 322 & 0 & 0 & 0 & 0 & 0 & 0 & 0 & 0 & 0 & 0 & 0 & 0 \\
\hline 2000 & 2658 & 341 & 0 & 0 & 0 & 0 & 0 & 0 & 0 & 0 & 0 & 0 & 0 & 0 \\
\hline 2001 & 2961 & 388 & 0 & 0 & 0 & 0 & 0 & 0 & 0 & 0 & 0 & 0 & 0 & 0 \\
\hline 2002 & 3456 & 452 & 0 & 0 & 0 & 0 & 0 & 0 & 0 & 0 & 0 & 0 & 0 & 0 \\
\hline 2003 & 3384 & 436 & 0 & 0 & 0 & 0 & 0 & 0 & 0 & 0 & 0 & 0 & 0 & 0 \\
\hline 2004 & 3852 & 500 & 0 & 0 & 0 & 0 & 0 & 0 & 0 & 0 & 0 & 0 & 0 & 0 \\
\hline 2005 & 3685 & 475 & 0 & 0 & 0 & 0 & 0 & 0 & 0 & 0 & 0 & 0 & 0 & 0 \\
\hline 2006 & 3731 & 480 & 0 & 0 & 0 & 0 & 0 & 0 & 0 & 0 & 0 & 0 & 0 & 0 \\
\hline 2007 & 4109 & 534 & 0 & 0 & 0 & 0 & 0 & 0 & 0 & 0 & 0 & 0 & 0 & 0 \\
\hline 2008 & 1111 & 146 & 0 & 0 & 0 & 0 & 0 & 0 & 0 & 0 & 0 & 0 & 0 & 0 \\
\hline 2009 & 1775 & 222 & 0 & 0 & 0 & 0 & 0 & 0 & 0 & 0 & 0 & 0 & 0 & 0 \\
\hline 2010 & 1275 & 168 & 0 & 0 & 0 & 0 & 0 & 0 & 0 & 0 & 0 & 0 & 0 & 0 \\
\hline 2011 & 957 & 124 & 0 & 0 & 0 & 0 & 0 & 0 & 0 & 0 & 0 & 0 & 0 & 0 \\
\hline 2012 & 0 & 0 & 0 & 0 & 0 & 0 & 0 & 0 & 0 & 0 & 0 & 0 & 0 & 0 \\
\hline 2013 & 0 & 0 & 0 & 0 & 0 & 0 & 0 & 0 & 0 & 0 & 0 & 0 & 0 & 0 \\
\hline 2014 & 0 & 0 & 0 & 0 & 0 & 0 & 0 & 0 & 0 & 0 & 0 & 0 & 0 & 0 \\
\hline 2015 & 0 & 0 & 0 & 0 & 0 & 0 & 0 & 0 & 0 & 0 & 0 & 0 & 0 & 0 \\
\hline 2016 & 0 & 0 & 0 & 0 & 0 & 0 & 0 & 0 & 0 & 0 & 0 & 0 & 0 & 0 \\
\hline 2017 & 0 & 0 & 0 & 0 & 0 & 0 & 0 & 0 & 0 & 0 & 0 & 0 & 0 & 0 \\
\hline 2018 & 0 & 0 & 0 & 0 & 0 & 0 & 0 & 0 & 0 & 0 & 0 & 0 & 0 & 0 \\
\hline 2019 & 0 & 0 & 0 & 0 & 0 & 0 & 0 & 0 & 0 & 0 & 0 & 0 & 0 & 0 \\
\hline 2020 & 0 & 0 & 0 & 0 & 0 & 0 & 0 & 0 & 0 & 0 & 0 & 0 & 0 & 0 \\
\hline
\end{tabular}

Note: Positive number denotes incoming shipment, negative number denotes outgoing shipment. 
TABLE C.25. Rail Shipment Unit Cost Elements

\begin{tabular}{|c|c|c|c|c|c|c|c|}
\hline $\begin{array}{c}\text { Cargo/ } \\
\text { Shipping Distance }\end{array}$ & $\begin{array}{c}\text { Cask Rental } \\
\text { Fee } \\
\end{array}$ & Shipping & Charge & $\begin{array}{l}\text { Security } \\
\text { Costs } \\
\end{array}$ & $\begin{array}{l}\text { Demurrage } \\
\text { at Origin } \\
\end{array}$ & $\begin{array}{l}\text { Demurrage } \\
\text { at MRS/IS } \\
\end{array}$ & $\begin{array}{c}\text { Total } \\
\text { (\$/Shipment) } \\
\end{array}$ \\
\hline $\begin{array}{l}\text { Spent Fuel } \\
500 \mathrm{mi} \\
2000 \mathrm{mi} \\
2500 \mathrm{mi}\end{array}$ & $\begin{array}{r}46,000 \\
138,000 \\
172,500\end{array}$ & $\begin{array}{r}9,910 \\
22,220 \\
25,910\end{array}$ & $\begin{array}{r}8,590 \\
19,140 \\
22,630\end{array}$ & $\begin{array}{r}3,640 \\
14,560 \\
18,200\end{array}$ & $\begin{array}{l}11,500 \\
11,500 \\
11,500\end{array}$ & $\begin{array}{l}11,500 \\
11,500 \\
11,500\end{array}$ & $\begin{array}{r}91,140 \\
216,920 \\
262,240\end{array}$ \\
\hline $\begin{array}{l}\text { High-Level Wastes } \\
500 \mathrm{mi} \\
2500 \mathrm{mi}\end{array}$ & $\begin{array}{r}46,000 \\
172,500\end{array}$ & $\begin{array}{r}9,980 \\
26,090\end{array}$ & $\begin{array}{r}8,590 \\
22,630\end{array}$ & $\begin{array}{r}3,640 \\
18,200\end{array}$ & $\begin{array}{l}11,500 \\
11,500\end{array}$ & $\begin{array}{l}11,500 \\
11,500\end{array}$ & $\begin{array}{r}91,210 \\
262,410\end{array}$ \\
\hline $\begin{array}{l}\text { RHTRU Waste Cans } \\
500 \mathrm{mi} \\
2500 \mathrm{mi}\end{array}$ & $\begin{array}{r}35,000 \\
131,250\end{array}$ & $\begin{array}{l}10,110 \\
26,430\end{array}$ & $\begin{array}{r}7,060 \\
18,590\end{array}$ & $\begin{array}{l}0 \\
0\end{array}$ & $\begin{array}{l}8,750 \\
8,750\end{array}$ & $\begin{array}{l}8,750 \\
8,750\end{array}$ & $\begin{array}{r}69,670 \\
193,770\end{array}$ \\
\hline $\begin{array}{l}\text { RHTRU Drums }<5 \mathrm{R} / \mathrm{hr} \\
500 \mathrm{mi} \\
2500 \mathrm{mi}\end{array}$ & $\begin{array}{r}4,200 \\
15,750\end{array}$ & $\begin{array}{r}8,540 \\
23,320\end{array}$ & $\begin{array}{r}6,250 \\
16,360\end{array}$ & $\begin{array}{l}0 \\
0\end{array}$ & $\begin{array}{l}1,050 \\
1,050\end{array}$ & $\begin{array}{l}1,050 \\
1,050\end{array}$ & $\begin{array}{l}21,090 \\
57,530\end{array}$ \\
\hline $\begin{array}{l}\text { RHTRU Drums }>5 \mathrm{R} / \mathrm{hr} \\
500 \mathrm{mi} \\
2500 \mathrm{mi}\end{array}$ & $\begin{array}{r}4,200 \\
15,750\end{array}$ & $\begin{array}{r}7,930 \\
20,720\end{array}$ & $\begin{array}{r}6,540 \\
17,110\end{array}$ & $\begin{array}{l}0 \\
0\end{array}$ & $\begin{array}{l}1,050 \\
1,050\end{array}$ & $\begin{array}{l}1,050 \\
1,050\end{array}$ & $\begin{array}{l}20,770 \\
55,680\end{array}$ \\
\hline $\begin{array}{l}\text { CHTRU Wastes } \\
500 \mathrm{mi} \\
2500 \mathrm{mi}\end{array}$ & $\begin{array}{l}11,200 \\
42,000\end{array}$ & $\begin{array}{r}6,090 \\
15,920\end{array}$ & $\begin{array}{l}2,710 \\
7,080\end{array}$ & $\begin{array}{l}0 \\
0\end{array}$ & $\begin{array}{l}2,800 \\
2,800\end{array}$ & $\begin{array}{l}2,800 \\
2,800\end{array}$ & $\begin{array}{l}25,600 \\
70,600\end{array}$ \\
\hline
\end{tabular}


TABLE C.26. Truck Shipment Unit Cost Elements

\begin{tabular}{|c|c|c|c|c|c|c|c|}
\hline $\begin{array}{c}\text { Cargo/ } \\
\text { Shipping Distance } \\
\end{array}$ & $\begin{array}{c}\text { Cask Rental } \\
\text { Fee } \\
\end{array}$ & $\begin{array}{l}\text { Shipping } \\
\text { Loaded }\end{array}$ & $\frac{\text { Charge }}{\text { Empty }}$ & $\begin{array}{c}\text { Security } \\
\text { Costs } \\
\end{array}$ & $\begin{array}{l}\text { Demurrage } \\
\text { at Origin } \\
\end{array}$ & $\begin{array}{l}\text { Demurrage } \\
\text { at MRS/IS } \\
\end{array}$ & $\begin{array}{c}\text { Total } \\
\text { (\$/Shipment) }\end{array}$ \\
\hline $\begin{array}{l}\text { Spent Fuel } \\
500 \mathrm{mi} \\
2000 \mathrm{mi} \\
2500 \mathrm{mi}\end{array}$ & $\begin{array}{r}4,000 \\
12,000 \\
14,000\end{array}$ & $\begin{array}{l}1,630 \\
4,960 \\
6,810\end{array}$ & $\begin{array}{r}980 \\
3,910 \\
4,900\end{array}$ & $\begin{array}{r}860 \\
3,440 \\
4,300\end{array}$ & $\begin{array}{l}2,000 \\
2,000 \\
2,000\end{array}$ & $\begin{array}{l}2,700 \\
2,700 \\
2,700\end{array}$ & $\begin{array}{l}12,170 \\
29,010 \\
34,710\end{array}$ \\
\hline $\begin{array}{l}\text { High-Level Wastes } \\
500 \mathrm{mi} \\
2500 \mathrm{mi}\end{array}$ & $\begin{array}{r}4,000 \\
14,000\end{array}$ & $\begin{array}{l}1,660 \\
6,310\end{array}$ & $\begin{array}{r}980 \\
4,900\end{array}$ & $\begin{array}{r}860 \\
4,300\end{array}$ & $\begin{array}{l}2,000 \\
2,000\end{array}$ & $\begin{array}{l}2,700 \\
2,700\end{array}$ & $\begin{array}{l}12,200 \\
34,210\end{array}$ \\
\hline $\begin{array}{l}\text { RHTRU Waste Cans } \\
500 \mathrm{mi} \\
2500 \mathrm{mi}\end{array}$ & $\begin{array}{r}3,500 \\
12,250\end{array}$ & $\begin{array}{l}1,070 \\
4,050\end{array}$ & $\begin{array}{r}510 \\
2,530\end{array}$ & $\begin{array}{l}0 \\
0\end{array}$ & $\begin{array}{l}1,750 \\
1,750\end{array}$ & $\begin{array}{l}2,450 \\
2,450\end{array}$ & $\begin{array}{r}9,280 \\
23,030\end{array}$ \\
\hline $\begin{array}{l}\text { RHTRU Drums }<5 \mathrm{R} / \mathrm{hr} \\
500 \mathrm{mi} \\
2500 \mathrm{mi}\end{array}$ & $\begin{array}{r}350 \\
1,225\end{array}$ & $\begin{array}{l}1,380 \\
5,220\end{array}$ & $\begin{array}{r}670 \\
3,330\end{array}$ & $\begin{array}{l}0 \\
0\end{array}$ & $\begin{array}{l}175 \\
175\end{array}$ & $\begin{array}{l}875 \\
875\end{array}$ & $\begin{array}{r}3,450 \\
10,825\end{array}$ \\
\hline $\begin{array}{l}\text { RHTRU Drums }>5 \mathrm{R} / \mathrm{hr} \\
500 \mathrm{mi} \\
2500 \mathrm{mi}\end{array}$ & $\begin{array}{r}350 \\
1,225\end{array}$ & $\begin{array}{l}1,280 \\
4,890\end{array}$ & $\begin{array}{r}700 \\
3,480\end{array}$ & $\begin{array}{l}0 \\
0\end{array}$ & $\begin{array}{l}175 \\
175\end{array}$ & $\begin{array}{l}875 \\
875\end{array}$ & $\begin{array}{r}3,380 \\
10,645\end{array}$ \\
\hline $\begin{array}{l}\text { CHTRU Wastes } \\
500 \mathrm{mi} \\
2500 \mathrm{mi}\end{array}$ & $\begin{array}{l}1,400 \\
4,900\end{array}$ & $\begin{array}{l}1,380 \\
5,220\end{array}$ & $\begin{array}{r}430 \\
2,160\end{array}$ & $\begin{array}{l}0 \\
0\end{array}$ & $\begin{array}{l}700 \\
700\end{array}$ & $\begin{array}{l}1,400 \\
1,400\end{array}$ & $\begin{array}{r}5,310 \\
14,380\end{array}$ \\
\hline
\end{tabular}


TABLE C.27. Annual Transportation Costs for Each Waste Form and the Total Transportation Costs for the MRS/IS Facility - Reference Scenario (\$1000's)

\begin{tabular}{|c|c|c|c|c|c|c|}
\hline YEAR & $\begin{array}{l}\text { Spent } \\
\text { Fuel }\end{array}$ & $\begin{array}{l}\text { High- } \\
\text { Level } \\
\text { Wastes }\end{array}$ & $\begin{array}{l}\text { RH-TRU } \\
\text { Special } \\
\text { Canisters }\end{array}$ & $\begin{array}{l}\text { RH-TRU } \\
\text { Drums }\end{array}$ & $\begin{array}{l}\mathrm{CH}-\mathrm{TRU} \\
\text { Drums } \\
\text { and Boxes }\end{array}$ & TOTAL \\
\hline 1990 & & 10,300 & 5,800 & 293 & 1,282 & 17,675 \\
\hline 1991 & & 20,338 & 11,407 & 565 & 2,484 & 34,794 \\
\hline 1992 & 0 & 30,342 & 16,991 & 824 & 3,761 & 51,918 \\
\hline 1993 & 0 & 30,342 & 16,991 & 824 & 3,761 & 51,918 \\
\hline 1994 & 0 & 30,342 & 16,991 & 824 & 3,761 & 51,918 \\
\hline 1995 & 0 & 30,342 & 16,991 & 824 & 3,761 & 51,918 \\
\hline 1996 & 0 & 30,342 & 16,991 & 824 & 3,761 & 51,918 \\
\hline 1997 & 0 & 30,342 & 16,991 & 824 & 3,761 & 51,918 \\
\hline 1998 & 0 & 0 & 0 & 0 & 0 & 0 \\
\hline 1999 & 0 & 0 & 0 & 0 & 0 & 0 \\
\hline 2000 & 0 & 0 & 0 & 0 & 0 & 0 \\
\hline 2001 & 0 & & 0 & 0 & 0 & \\
\hline 2002 & 0 & 0 & 0 & 0 & 0 & 0 \\
\hline 2003 & 0 & 0 & 0 & 0 & 0 & 0 \\
\hline 2004 & 0 & 0 & 0 & 0 & 0 & 0 \\
\hline 2005 & 0 & 0 & 0 & 0 & 0 & 0 \\
\hline 2006 & 0 & 0 & 0 & 0 & 0 & 0 \\
\hline 2007 & 0 & 0 & 0 & 0 & 0 & 0 \\
\hline 2008 & 0 & 0 & 0 & 0 & 0 & 0 \\
\hline 2009 & 0 & 0 & 0 & 0 & 0 & 0 \\
\hline 2010 & 0 & 0 & 0 & 0 & 0 & 0 \\
\hline 2011 & 0 & 20,338 & 1,213 & 65 & 313 & 21,929 \\
\hline 2012 & 0 & 10,300 & 0 & 0 & 0 & 10,300 \\
\hline 2013 & 0 & 18,205 & 6,796 & 336 & 1,561 & 26,898 \\
\hline 2014 & 0 & 30,342 & 6,796 & 336 & 1,561 & 39,035 \\
\hline 2015 & 0 & 0 & 0 & 0 & 0 & 0 \\
\hline 2016 & 0 & 0 & 0 & 0 & 0 & 0 \\
\hline 2017 & 0 & 0 & 0 & 0 & 0 & 0 \\
\hline 2018 & 0 & 0 & 0 & 0 & 0 & 0 \\
\hline 2019 & 0 & 0 & 0 & 0 & 0 & 0 \\
\hline 2020 & $\frac{0}{0}$ & $\frac{0}{291,875}$ & $\frac{0}{133,958}$ & $\frac{0}{6,539}$ & $\frac{0}{29,767}$ & $\frac{0}{462,139}$ \\
\hline
\end{tabular}


TABLE C.28. Annual Transportation Costs for Each Waste Form Delayed Reprocessing Scenario (\$1000's)

\begin{tabular}{|c|c|c|c|c|c|c|}
\hline Year & $\frac{\text { Spen }}{2500 \mathrm{mi} .}$ & $\frac{\text { Fuel }}{2000 \mathrm{mi} .}$ & $\begin{array}{r}\text { High- } \\
\text { Level } \\
\text { Wastes } \\
\end{array}$ & $\begin{array}{r}\text { RH-TRU } \\
\text { Special } \\
\text { Canisters } \\
\end{array}$ & $\begin{array}{l}\text { RH-TRU } \\
\text { Drums } \\
\end{array}$ & $\begin{array}{r}\mathrm{CH}-\mathrm{TRU} \\
\text { Drums } \\
\text { and Boxes } \\
\end{array}$ \\
\hline 1990 & 40,097 & 32,816 & 0 & 0 & 0 & 0 \\
\hline 1991 & 45,893 & 37,548 & 0 & 0 & 0 & 0 \\
\hline 1992 & 56,140 & 46.151 & 0 & 0 & 0 & 0 \\
\hline 1993 & 58,091 & 47.166 & 0 & 0 & 0 & 0 \\
\hline 1994 & 87,039 & 71,308 & 0 & 0 & 0 & 0 \\
\hline 1995 & 108,416 & 88,816 & 0 & 0 & 0 & 0 \\
\hline 1996 & 130,202 & 106,462 & 0 & 0 & 0 & 0 \\
\hline 1997 & 130,340 & 106,665 & 0 & 0 & 0 & 0 \\
\hline 1998 & 0 & 0 & 0 & 0 & 0 & 0 \\
\hline 1999 & 0 & 0 & 0 & 0 & 0 & 0 \\
\hline 2000 & 0 & 0 & 0 & 0 & 0 & 0 \\
\hline 2001 & 0 & 0 & 0 & 0 & 0 & 0 \\
\hline 2002 & 0 & 0 & 0 & 0 & 0 & 0 \\
\hline 2003 & 0 & 0 & 0 & 0 & 0 & 0 \\
\hline 2004 & 0 & 0 & 0 & 0 & 0 & 0 \\
\hline 2005 & 0 & 0 & 0 & 0 & 0 & 0 \\
\hline 2006 & 0 & 0 & 0 & 0 & 0 & 0 \\
\hline 2007 & 0 & 0 & 0 & 0 & 0 & 0 \\
\hline 2008 & 0 & 0 & 0 & 0 & 0 & 0 \\
\hline 2009 & 0 & 0 & 0 & 0 & 0 & 0 \\
\hline 2010 & 0 & 0 & 0 & 0 & 0 & 0 \\
\hline 2011 & 0 & 0 & 0 & 0 & 0 & 0 \\
\hline 2012 & 54,267 & 0 & 0 & 0 & 0 & 0 \\
\hline 2013 & 42,779 & 0 & 0 & 0 & 0 & 0 \\
\hline 2014 & 76,229 & 0 & 0 & 0 & 0 & 0 \\
\hline 2015 & 155,783 & 0 & 0 & 0 & 0 & 0 \\
\hline 2016 & 238,458 & 0 & 0 & 0 & 0 & 0 \\
\hline 2017 & 88,851 & 0 & 0 & 0 & 0 & 0 \\
\hline 2018 & 0 & 0 & 0 & 0 & 0 & 0 \\
\hline 2019 & 0 & 0 & 0 & 0 & 0 & 0 \\
\hline \multirow[t]{2}{*}{2020} & 0 & 0 & $\underline{0}$ & $\underline{0}$ & $\underline{0}$ & $\underline{0}$ \\
\hline & 1312,600 & 1193,139 & $\overrightarrow{0}$ & 0 & $\overline{0}$ & $\overline{0}$ \\
\hline
\end{tabular}


TABLE C.29. Annual Transportation Costs for Each Waste Form - Delayed Disposal Scenario ( $\$ 1000$ 's)

\begin{tabular}{|c|c|c|c|c|c|c|}
\hline YEAR & $\begin{array}{l}\text { Spent } \\
\text { Fuel }\end{array}$ & $\begin{array}{l}\text { High- } \\
\text { Levei } \\
\text { wastes }\end{array}$ & $\begin{array}{l}\text { RH-TRU } \\
\text { Special } \\
\text { Canisters }\end{array}$ & $\begin{array}{l}\text { RH-TRU } \\
\text { Orums }\end{array}$ & $\begin{array}{l}\text { CH-TRU } \\
\text { Orums } \\
\text { and Eioxes }\end{array}$ & TOTAL \\
\hline 1990 & & 10,300 & 5,800 & 293 & 1,292 & 17,675 \\
\hline 1991 & & 20,338 & 11,407 & 565 & 2,484 & 34,794 \\
\hline $\begin{array}{l}1992 \\
1993\end{array}$ & $\begin{array}{l}0 \\
0\end{array}$ & $\begin{array}{l}30,342 \\
30,342\end{array}$ & $\begin{array}{l}16,991 \\
16,991\end{array}$ & $\begin{array}{l}824 \\
824\end{array}$ & $\begin{array}{l}3,761 \\
3,761\end{array}$ & $\begin{array}{l}51,918 \\
51,918\end{array}$ \\
\hline 1994 & 0 & 30,342 & 16,991 & 824 & 3,761 & 51,918 \\
\hline 1995 & 0 & 30,342 & 16,991 & 824 & 3,761 & 51,918 \\
\hline 1996 & 0 & 30,342 & 16,991 & 824 & 3,761 & 51,918 \\
\hline 1997 & 0 & 30,342 & 16,991 & 824 & 3,761 & 51,918 \\
\hline 1998 & 0 & 30,342 & 16,991 & 824 & 3,761 & 51,918 \\
\hline 1999 & 0 & 30,342 & 16,991 & 824 & 3,761 & 51,918 \\
\hline 2000 & 0 & 30,342 & 16,991 & 824 & 3,761 & 51,918 \\
\hline 2001 & 0 & 40,506 & 22,676 & 1,096 & 4,954 & 69,232 \\
\hline 2002 & 0 & 50,612 & 28,227 & 1,389 & 6,217 & 86,445 \\
\hline 2003 & 0 & 60,684 & 33,935 & 1,626 & 6,614 & 102,859 \\
\hline 2004 & 0 & 60,684 & 33,935 & 1,626 & 6,614 & 102,859 \\
\hline 2005 & 0 & 60,684 & 33,935 & 1,626 & 6,614 & 102,859 \\
\hline 2006 & 0 & 80,954 & 45,273 & 2,180 & 9,949 & 138,356 \\
\hline 2007 & 0 & 101,224 & 56,532 & 2,722 & 12,353 & 172,841 \\
\hline 2008 & 0 & 84,958 & 44,438 & 2,047 & 9,723 & 141,166 \\
\hline 2009 & 0 & 84,958 & 44,438 & 2,047 & 9,723 & 141,166 \\
\hline 2010 & 0 & 84,958 & 44,438 & 2,047 & 9,723 & 141,166 \\
\hline 2011 & 0 & 105,228 & 55,799 & 2,700 & 12,193 & 175,920 \\
\hline 2012 & 0 & 58,746 & 26,636 & 1,279 & 5,890 & 92,551 \\
\hline 2013 & 0 & 32,806 & 7,084 & 1,085 & 4,925 & 45,900 \\
\hline 2014 & 0 & 54,616 & 7,084 & 1,085 & 4,925 & 67,710 \\
\hline 2015 & 0 & 7,300 & 0 & 0 & 0 & 7,300 \\
\hline 2016 & 0 & 10,996 & 0 & 0 & 0 & 10,996 \\
\hline 2017 & 0 & 0 & 0 & 0 & 0 & 0 \\
\hline 2018 & 0 & 0 & 0 & 0 & 0 & 0 \\
\hline 2019 & 0 & 0 & 0 & 0 & 0 & 0 \\
\hline \multirow[t]{2}{*}{2020} & 0 & 0 & 0 & 0 & $\begin{array}{l}0 \\
\end{array}$ & - \\
\hline & 0 & 1283,630 & 554,556 & 32,829 & 148,043 & 2119,058 \\
\hline
\end{tabular}


TABLE C.30. Annual Transportation Costs for Each Waste

Form - Early Disposal Scenario (\$1000's)

\begin{tabular}{|c|c|c|c|c|c|c|}
\hline IEAR & $\begin{array}{l}\text { Spent } \\
\text { Fue } 1\end{array}$ & $\begin{array}{l}\text { High- } \\
\text { Leve1 } \\
\text { wastes }\end{array}$ & $\begin{array}{c}\text { RH-TRU } \\
\text { Specia } 7 \\
\text { Canisters }\end{array}$ & $\begin{array}{l}\text { RH-TRU } \\
\text { Drums }\end{array}$ & $\begin{array}{c}\text { CH-TRU } \\
\text { Drums } \\
\text { and Boxes }\end{array}$ & TOTAL \\
\hline 1990 & & 10,300 & 5,800 & 293 & 1,292 & 17,685 \\
\hline 1991 & & 20,338 & 11,407 & 565 & 2,484 & 34,794 \\
\hline 1992 & 0 & 30,342 & 16,991 & 824 & 3,761 & 51,918 \\
\hline 1993 & 0 & 0 & 0 & 0 & 0 & 0 \\
\hline 1994 & 0 & 0 & 0 & 0 & 0 & 0 \\
\hline 1995 & 0 & 0 & 0 & 0 & 0 & 0 \\
\hline 1996 & 0 & 0 & 0 & 0 & 0 & 0 \\
\hline 1997 & 0 & 0 & 0 & 0 & 0 & 0 \\
\hline 1998 & 0 & 0 & 0 & 0 & 0 & 0 \\
\hline 1999 & 0 & 0 & 0 & 0 & 0 & 0 \\
\hline 2000 & 0 & 0 & 0 & 0 & 0 & 0 \\
\hline 2001 & 0 & 0 & 0 & 0 & 0 & 0 \\
\hline 2002 & 0 & 0 & 0 & 0 & 0 & 0 \\
\hline 2003 & 0 & 0 & 0 & 0 & 0 & 0 \\
\hline 2004 & 0 & 0 & 0 & 0 & 0 & 0 \\
\hline 2005 & 0 & 0 & 0 & 0 & 0 & 0 \\
\hline 2006 & 0 & 0 & 0 & 0 & 0 & 0 \\
\hline 2007 & 0 & 0 & 0 & 0 & 0 & 0 \\
\hline 2008 & 0 & 0 & 0 & 0 & 0 & 0 \\
\hline 2009 & 0 & 0 & 0 & 0 & 0 & 0 \\
\hline 2010 & 0 & 0 & 0 & 0 & 0 & 0 \\
\hline 2011 & 0 & 0 & 0 & 0 & 0 & 0 \\
\hline 2012 & 0 & 0 & 0 & 0 & 0 & 0 \\
\hline 2013 & 0 & 0 & 0 & 0 & 0 & 0 \\
\hline 2014 & 0 & 0 & 0 & 0 & 0 & 0 \\
\hline 2015 & 0 & 0 & 0 & 0 & 0 & 0 \\
\hline 2016 & 0 & 0 & 0 & 0 & 0 & 0 \\
\hline 2017 & 0 & 0 & 0 & 0 & 0 & 0 \\
\hline 2018 & 0 & 0 & 0 & 0 & 0 & 0 \\
\hline 2019 & 0 & 0 & 0 & 0 & 0 & 0 \\
\hline \multirow[t]{2}{*}{2020} & 0 & 0 & 0 & 0 & 0 & 0 \\
\hline & 0 & 60,980 & 34,198 & 1,682 & 7,537 & 104,397 \\
\hline
\end{tabular}


TABLE C.31. Annual Transportation Costs for Each Waste Form - Delayed Disposal, No Reprocessing ( $\$ 1000^{\prime} s$ )

\begin{tabular}{|c|c|c|c|c|c|}
\hline YEAR & $\begin{array}{l}\text { Surnt } \\
\text { Fuel }\end{array}$ & $\begin{array}{l}\text { High- } \\
\text { Level } \\
\text { Wastes }\end{array}$ & $\begin{array}{l}\text { PH-TPI } \\
\text { Special } \\
\text { Canistars }\end{array}$ & $\begin{array}{l}\text { PH-TRU } \\
\text { Dr:mis }\end{array}$ & $\begin{array}{c}\mathrm{CH}-\mathrm{TPU} \\
\text { Drulis } \\
\text { and } \mathrm{Boxes}\end{array}$ \\
\hline 1990 & 40,166 & 0 & 0 & 0 & 0 \\
\hline 1991 & 46,186 & 0 & 0 & 0 & 0 \\
\hline 1992 & 56,487 & 0 & 0 & 0 & 0 \\
\hline 1993 & 57,725 & 0 & 0 & 0 & 0 \\
\hline 1994 & 87,282 & 0 & 0 & 0 & 0 \\
\hline 1995 & 108,694 & 0 & 0 & 0 & 0 \\
\hline 1996 & 130,306 & 0 & 0 & 0 & 0 \\
\hline 1997 & 130,564 & 0 & 0 & 0 & 0 \\
\hline 1998 & 149,835 & 0 & 0 & 0 & 0 \\
\hline 1999 & 170,002 & 0 & 0 & 0 & 0 \\
\hline 2000 & 181,683 & 0 & 0 & 0 & 0 \\
\hline 2001 & 204,525 & 0 & 0 & 0 & 0 \\
\hline 2002 & 238,490 & 0 & 0 & 0 & 0 \\
\hline 2003 & 231,795 & 0 & 0 & 0 & 0 \\
\hline 2004 & 264,823 & 0 & 0 & 0 & 0 \\
\hline 2005 & 252,470 & 0 & 0 & 0 & 0 \\
\hline 2006 & 255,378 & 0 & 0 & 0 & 0 \\
\hline 2007 & 282,660 & 0 & 0 & 0 & 0 \\
\hline 2008 & 76,850 & 0 & 0 & 0 & 0 \\
\hline 2009 & 119,828 & 0 & 0 & 0 & 0 \\
\hline 2010 & 88,312 & 0 & 0 & 0 & 0 \\
\hline 2011 & 66,522 & 0 & 0 & 0 & 0 \\
\hline 2012 & 0 & 0 & 0 & 0 & 0 \\
\hline 2013 & 0 & 0 & 0 & 0 & 0 \\
\hline 2014 & 0 & 0 & 0 & 0 & 0 \\
\hline 2015 & 0 & 0 & 0 & 0 & 0 \\
\hline 2016 & 0 & 0 & 0 & 0 & 0 \\
\hline 2017 & 0 & 0 & 0 & 0 & 0 \\
\hline 2018 & 0 & 0 & 0 & 0 & 0 \\
\hline 2019 & 0 & 0 & 0 & 0 & 0 \\
\hline \multirow[t]{2}{*}{2020} & 0 & 0 & 0 & 0 & 0 \\
\hline & $3,240,583$ & 0 & 0 & $\overline{0}$ & 0 \\
\hline
\end{tabular}


APPENDIX D

GENERAL CRITERIA AND STANDARDS 
APPENDIX D

GENERAL CRITERIA AND STANDARDS

Design and construction of the facilities described in Section 4 of this report will be in accordance with the applicable sections of the following regulations, codes, standards, and guides, as well as their applicable references. Other codes and standards may be selected and used during the subsequent design phases.

\section{D.1 U.S. GOVERNMENT STANDARDS, REGULATIONS, AND GUIDES}

National Environmental Policy Act (NEPA)

40 CFR 1500-1508

Occupational Safety and Health Administration (OSHA)

Code of Federal Regulations (CFR)

10 CFR 20, Standards for Protection Against Radiation

10 CFR 30, Rules of General Applicability to Domestic Licensing of By-Product Material

10 CFR 50, Domestic Licensing of Production and Utilization Facilities

10 CFR 51, Licensing and Regulatory Policy and Procedures for Environmental Protection

10 CFR 55, Operators' Licenses

10 CFR 60, Disposal of High-Level Radioactive Wastes in Geologic Repositories (Proposed)

10 CFR 70, Domestic Licensing of Special Nuclear Material

10 CFR 71, Packaging of Radioactive Material for Transport and Transportation of Radioative Material under Certain Conditions

10 CFR 72, Licensing Requirements for the Storage of Spent Fuel in an Independent Spent Fuel Storage Installation (ISFSI)

10 CFR 73, Physical Protection of Plants and Mațerials

10 CFR 75, Safeguard of Nuclear Material (when issued)

$$
\text { D.1 }
$$


10 CFR 95, Security Facility Approval and Safeguarding of National Security Information and Restricted Data

10 CFR 100, Reactor Site Criteria

10 CFR 150, Exemptions and Continued Regulatory Authority in Agreement States under Section 274

10 CFR 170, Fees for Facilities and Materials Licenses and 0ther Regulatory Services under the Atomic Energy Act of 1954, as Amended

10 CFR 1022, Compliance with Floodplain/Wetland Environmental Review Requirements

29 CFR 1910, Occupational Safety and Health Standards

40 CFR, Protection of the Environment

49 CFR 127, 191.179, Hazardous Materials Regulations

49 CFR 173.393, General Packaging and Shipment Requirements

U.S. Nuclear Regulatory Commission (NRC) Regulatory Guides

1.12, Fire Protection Guidelines for Nuclear Power Plants

1.21, Measuring, Evaluating, and Reporting Radioactivity in Solid Wastes and Releases of Radioactive Materials in Liquid and Gaseous Effluents from Light-Water-Cooled Nuclear Power Plants

\subsection{3, Radiation Protection Design Features}

1.25, Assumptions used for Evaluating the Potential Radiological Consequences of a Fuel-Handling Accident in the Fuel Handling and Storage Facility

1.28, Quality Assurance Program Requirements (Design and Construction) Revision 2, File 1979

1.32, Criteria for Safety-Related Electric Power Systems for Nuclear Power Plants

1.60, Design Response Spectra for Seismic Design of Nuclear Power Plants

1.76, Design Basis Tornado for Nuclear Power Plants

3.16, General Fire Protection Guide for Plutonium Processing and Fuel Fabrication Plants

3.24, Guidance on the License Applications Siting, Design, and Plant Protection for an Independent Spent Fuel Storage Installation 
8.8, Information Relevant to Ensuring that 0ccupational Radiation Exposures at Nuclear Power Stations will be as Low as is Reasonably Achievable

8.10, Operating Philosophy for Maintaining Occupational Exposure as Low as is Reasonably Achievable

U.S. Department of Energy (DOE)

Manual Chapters (MC)

0505, Construction Safety

0511, Radioactive Waste Management

0513, Effluent and Environmental Monitoring and Reporting

0524, Standards for Radiation Protection

0529, Safety Standards for the Packaging of Fissile and Other Radioactive Materials

0530, Nuclear Criticality Safety

0550, Operational Safety Standards

0552, Fire Protection

6106, Management of Construction Projects

6203, Site Development and Facility Utilization Planning

6301, Facilities General Design Criteria

Federal Specification

W-A-00450B, Components for Alarm Systems, Interior Security

Reactor Development Technology (RDT) Standards

F1-2T, Preparation of System Design Descriptions

Richland Operations Office Orders

6400, Management of Construction Projects, Exhibit 2, Functional Design Criteria

5820.2, Radioactive Waste Management

U.S. Department of Transportation (DOT) 
National Bureau of Standards (NBS)

Hanford Plant Standards (HPS) Standard Design Criteria (SDC)

SDC 2.1, Standard Design Criteria for Architectural Design

SDC 3.1, Standard Design Criteria for Railroads

SDC 3.2, Minimum Depth of Underground Water Lines

SDC 4.1, Standard Architectural-Civil Design Criteria, Design Loads of structures

SDC 5.1, Standard Design Criteria for Heating, Ventilating, and Air Conditioning

SDC 7.2, Standard Electrical Design Criteria for Outside Lighting and Aerial Distribution Systems

SDC 7.4, Standard Electrical Design Criteria for Underground Power Distribution Systems

SDC 7.5, Standard Electrical Design Criteria for Interior Power and Lighting Systems

SOC 7.7, Standard Electrical Design Criteria for Communication, Signaling, and Low-Voltage Systems

SDC 7.8, Standard Electrical Design Criteria for Fire Alarm Systems

SCC 7.10, Standard Electrical Design Criteria for Corrosion Protection Systems

E-11, Cathodic Protection Standards

E-12, Building Grounding

\section{D.2 STATE OF WASHINGTON PUBLICATIONS}

Washington Administrative Code

Chapter 296-52, Safety Standards for the Possession and Handling of Explosives

Chapter 296-155, Construction Standards

State of Washington High Manual

State of Washington Grid System 


\section{D.3 INDUSTRIAL AND PROFESSIONAL SOCIETY PUBLICATIONS}

In general, applicable "national concensus" codes and standards as developed by such organizations as the American Society of Mechanical Engineer, American Concrete Institute, American National Standards Institute and the Institute of Electrical and Electronic Engineers shall also be followed.

American Conference of Governmental Industry Hygienists (ACGIH)

Threshold Limit Values for Chemical Substances and Physical Agents in the Workroom Environment

Industrial Ventilation, 14th Edition

American Concrete Institute (ACI)

American National Standards Institute (ANSI)

A58.1-72, Building Code Requirements for Minimum Design Loads in Buildings and Other Structures

B30.2.0-76, Overhead and Gantry Cranes, Safety Code for (partial revision of $B 30.2-43$ )

B30.3-75, Hammerhead Tower Cranes, Partial Revision of B30.2-43 ( $R$ 1952)

B30.4-73, Portal, Towe, and Pillar Cranes, Safety Code for B30-9-71, Slings, Safety Code for (partial revision of B30.2-43)

B30.10-75, Hooks, Safety Standards for Cableways, Cranes, Hoists Hooks, Jacks, and Slings.

B30.11-73, Monorail Systems and Under-Hung Cranes

B30.13, Controlled Mechanical Storage Crane

B30.16-73, Overhead Hoists

B56.1, Lowered Industrial Trucks, Low Lift and High Lift Trucks, Safety Standards for (ISO/RI074); Design, Operation, Maintenance of Lowered Industrial Trucks (ISO/R1074)

C2-77, National Electrical Code

N13.1-69, Guide to Sampling Airborne Radioactive Materials in Nuclear Facilities 
N13.3-69, Dosimetry for Criticality Accidents

N13.10-74, Onsite Instrumentation for Continuously Monitoring Radioactivity in Effluents, Specification, and Performance of

N16.2-69, Criticality Accident Alarm System

N18.4-74, Earthquake Instrumentation Criteria for Nuclear Power Plants

N45.2-77, Quality Assurance Program Requirements for Nuclear Facilities

S1.6-67, Preferred Frequencies and Band Numbers for Acoustical

Measurement

American Nuclear Society (ANS)

American Society of Civil Engineers (ASCE)

Paper Number 3269, Wind Forces on Structures

American Society of Heating, Refrigeration and Air Conditioning Engineers (ASHRAE)

1977 Fundamentals Handbook

American Society of Mechanical Engineers (ASME)

Boiler and Pressure Vessel Code, Section VII, Division 1, Pressure Vessels

American Society for Testing and Materials (ASTM)

American Water Works Association (AWWA)

Manual M-14, Backflow Prevention and Cross Connection Control

Standard C-506-69, Backflow Prevention Devices, Reduced Pressure

Principle and Double Check Valve Types

Factory Mutual Research Corporation Manual (FMRC)

7-88 Storage Tanks for Flammable Liquids

Government-Industry Data Exchange Program (GIDEP)

Institute of Electrical and Electronics Engineers (IEEE)

279-71, Criteria for Protection, Systems for Nuclear Power Generating Stations

D.6 
308-74, Standard Criteria for C1ass IE Power Systems for Nuclear Power Generating Stations

380-75, Definition of Terms used in IEEE Nuclear Power Generating Station Standard

383-74, IEEE Standard for Type Test of Class IE Electric Cables, Field Splices, and Connections for Nuclear Power Generating Stations

384-77, Criteria for Separation of Class IE Equipment and Circuits

422-77, Design and Installation of Cable Systems in Power Generating Stations

Insulated Power Cable Engineers Association (IPCEA)

National Fire Protection Assocation (NFPA)

30, Flammable and Combustible Liquids Code

70, National Electrical Code

71, Standard for Installations, Maintenance, and Use of Central Station Signaling Systems

72B, Installation, Maintenance, and Use of Auxiliary Protective Signaling Systems for Fire Alarm Service, Standard NFPA No. 72-B-1975

72E, Automatic Fire Detectors, Standard for NFPA No. 72E-1974

73, Installation, Maintenance, Use of Public Fire Service Communications Standard for

78, Lightning Protection Code

Underwriters' Laboratories, Inc. (UL)

586, Test Performance of High-Efficiency Particulate Air Filter Unit Uniform Building Code (UBC)

Section 2308, Tables 23-F, 23-G, and 23-H

Section 231 . 
No. of

Copies

OFFSITE

M. J. Lawrence

Nuclear Waste Policy. Act Project Office

U.S. Department of Energy NE-43

Washington, DC 20545

K. A. Klein, Director

Nuclear Waste Policy Act Project Office

U.S. Department of Energy NE -43

Washington, DC 20545

J. H. Carlson

Nuclear Waste Policy Act

Project Office

U.S. Department of Energy NE -43

Washington, DC 20545

S. P. Schneider

Nuclear Waste Policy Act

Project Office

U.S. Department of Energy NE -43

Washington, DC 20545

Len Lanni

Magnetic Fusion and Nuclear Division

U.S. Department of Energy

San Francisco Operations Office

1333 Broadway

Oakland, CA 94612

27 DOE Technical Information

Center
No. of

Copies

2 W. L. Godfrey

Allied-General Nuclear Services P.0. Box 847

Barnwel1, SC 29812-0847

2 D. W. Ketchen

General Atomic Technologies, Inc.

P.0. Box 81608

San Diego, CA 92138

R. B. Pope

Sandia National Laboratories

Transportation Technology Center

P.0. Box 5800

Albuquerque, NM 87185

J. M. Diggs

Sandia National Laboratories

Transportation Technology Center

P.0. Box 5800

Albuquerque, NM 87185

\section{ONSITE}

6 DOE Richland Operations Office

P. A. Craig

(4)

H. E. Ransom

J. J. Schreiber

Human Affairs Research Center

B. Berk

52 Pacific Northwest Laboratory

K. R. Ames

N. M. Burleigh

T. D. Chikalla 
No. of

Copies

B. M. Cole

J. F. Fletcher

D. L. Gale

C. A. Geffen

R. J. Hall (20)

G. M. Holter

W. S. Kelly

R. C. Liikala

H. D. Massey

P. N. McDuffie

J. L. McETroy
No. of

Copies

J. F. Nesbitt

D. F. Newman

D. R. Payson

D. E. Rasmussen

K. J. Schneider

R. L. Shaub

M. J. Sherbin

R. I. Smith (5)

Publishing Coordination (2)

Technical Information (5) 